\title{
Por uma edição crítico-genética virtual do livro Histórias da meia-noite, de Machado de Assis
}

Flávia BARretTo CorrêA CATITA

VERSÃO CORRIGIDA

São Paulo

2014 


\title{
Por uma edição crítico-genética virtual do livro Histórias da meia-noite, de Machado de Assis
}

\author{
Flávia Barretto CorrêA CATITA
}

VERSÃO CORRIGIDA

\begin{abstract}
DissertaÇÃo APRESENTADA Ao Programa DE PÓS-GRAduAÇÃo EM Literatura BRASILEIRA DO DEPARTAMENTO DE LETRAS CLÁSSICAS E VERnáculas da FACULDAdE DE FIlosofia, Letras E CiÊnCIAS Humanas da UNIVERSIDADE DE SÃo PAULO COMO REQUISITO PARCIAL PARA A OBTENÇÃO DO TíTULO DE MESTRE EM LETRAS
\end{abstract}

Orientador: Prof. Dr. Hélio de Seixas Guimarães

São Paulo

2014 


\title{
Por uma edição crítico-genética virtual do livro Histórias da meia-noite, de Machado de Assis
}

\author{
FlÁvia BARRETTO CORRÊA CATITA
}

\author{
VERSÃO CORRIGIDA
}

\begin{abstract}
DisSERTAÇÃo APRESENTADA AO PROGRAMA DE PÓS-GRAdUAÇÃo EM LiTERATURA BRASILEIRA DO DEPARTAMENTO DE LETRAS CLÁSSICAS E VERnÁCUlAS DA FACULDAdE DE FILOSOFIA, LETRAS E CIÊNCIAS HUMANAS DA UNIVERSIDADE DE SÃo PAUlO COMO REQUISITO PARCIAL PARA A OBTENÇÃO DO TÍTULO De Mestre em Letras
\end{abstract}

Orientador: Prof. Dr. Hélio de Seixas Guimarães

São Paulo

2014 
Catita, Flávia Barretto Corrêa.

Por uma edição crítico-genética virtual do livro Histórias da meia-noite, de Machado de Assis; Orientador Hélio de Seixas Guimarães - São Paulo, 2014.

179 páginas

Dissertação (Mestrado) - Faculdade de Filosofia, Letras e Ciências Humanas. Departamento de Letras Clássicas e Vernáculas. Área de Concentração: Literatura Brasileira

1. Edição critico-genética

2. Machado de Assis

3. Histórias da meia-noite

I. Faculdade de Filosofia, Letras e Ciências Humanas.

Departamento de Letras Clássicas e Vernáculas.

\section{Comissão Julgadora:}

Prof. Dr.

Prof. Dr.

Prof. Dr.

Hélio de Seixas Guimarães 
Para Adriano. 


\section{Agradecimentos}

Ao Programa de Pós-Graduação em Literatura Brasileira, da Faculdade de Filosofia, Letras e Ciências Humanas da Universidade de São Paulo.

À Fundação de Amparo à Pesquisa do Estado de São Paulo, pela concessão da bolsa de mestrado.

Ao meu orientador, professor Hélio de Seixas Guimarães, pelos direcionamentos e comentários sempre precisos.

Aos professores Marta de Senna e Manoel Mourivaldo Santiago Almeida, pelas sugestões quando do Exame de Qualificação.

Aos meus pais, por me ensinarem o valor da vida.

À minha família e amigos, pelo encorajamento.

Ao Adriano, pelo apoio e incentivo sempre presentes.

À Bruna, amiga e companheira de todas as horas, pela ajuda com a revisão do texto.

Ao Thiago Gomes Veríssimo, pela ajuda com a parte técnica de informática. Ao professor Marcos Lopes, pela ajuda com o LATEX.

Aos colegas da Pós-Graduação, pelas sugestões e discussões. 
O que Você chama a minha segunda maneira naturalmente me é mais aceita e cabal que a anterior, mas é doce achar quem se lembre desta, quem a penetre e desculpe, e até chegue a catar nela algumas raízes dos meus arbustos de hoje. (Machado de Assis, Carta a José Veríssimo, 15.12.1898) 


\section{Resumo}

Esta dissertação tem por objetivo elaborar uma Edição Crítico-Genética Virtual dos contos reunidos no livro Histórias da meia-noite, de Machado de Assis, os quais foram inicialmente publicados no periódico Jornal das Famílias. O trabalho pretende ressaltar as mudanças, supressões e acréscimos realizados pelo autor com a finalidade de esclarecer os processos de criação subjacentes à reescrita dos contos, assim como estabelecer relações entre os veículos de publicação e os diferentes perfis de leitores e compreender como o escritor se posicionava diante dessas peculiaridades. Pretende-se ainda disponibilizar esse conteúdo em um site que facilite a localização desses contos e a visualização das alterações. Com isso, espera-se propor também algumas bases para a realização de futuras edições de outras obras literárias.

Palavras-chave: Edição critico-genética. Machado de Assis. Histórias da meia-noite. 


\section{Abstract}

This dissertation's goal is to elaborate a Virtual Critical Genetic Edition of Historias da meia-noite's short stories, by Machado de Assis, which were first published in the periodic Jornal das Familias. This research aims to highlight the changes, deletions and additions made by the author in order to understand the creation process of those short stories, as well as the particularities of each media and public where they were first published. Furthermore, we intend to make it available to the public on a website that make it easier to locate and visualize the changes.

Keywords: Critical genetic edition. Machado de Assis. Histórias da meianoite. 


\section{Sumário}

$\begin{array}{ll}\text { Agradecimentos } & \mathbf{v}\end{array}$

Resumo vii

Abstract viii

$\begin{array}{lr}\text { Introdução } & 1\end{array}$

1 Jornal das Famílias e Histórias da meia-noite 4

2 Introdução crítico-filológica $\quad 11$

2.1 Normas e critérios adotados . . . . . . . . . . . . . . . 13

2.2 Opções tipográficas . . . . . . . . . . . . . . . . . . . . 14

2.3 Descrição dos testemunhos . . . . . . . . . . . . . . . . . . . . . . . . . . 14

2.4 Por uma nova forma de edição . . . . . . . . . . . . . 15

3 Edição crítico-genética $\quad 22$

3.1 "A parasita azul" . . . . . . . . . . . . . . . . . 22

3.2 "As bodas do Dr. Duarte" / "As bodas de Luís Duarte" . . . 60

3.3 "Ernesto de tal" . . . . . . . . . . . . . . . . . . . 74

3.4 "Aurora sem dia" . . . . . . . . . . . . . . . . . . . . 95

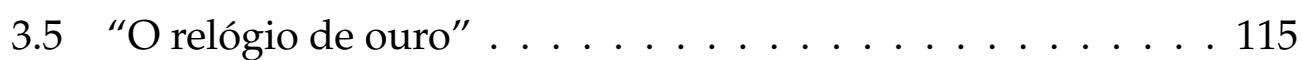

3.6 "Quem desdenha" / "Ponto de vista" . . . . . . . . . . . . . . 122

4 Análise do percurso genético $\quad 149$

4.1 O processo de omissão . . . . . . . . . . . . . . . . . . . . 149

4.2 O processo de adição . . . . . . . . . . . . . . . . . . . 153

4.3 O processo de substituição . . . . . . . . . . . . . . 156

$\begin{array}{ll}\text { Considerações Finais } & 163\end{array}$

$\begin{array}{ll}\text { Referências bibliográficas } & 167\end{array}$ 


\section{Introdução}

O que ainda se pode falar sobre Machado de Assis? Quais aspectos de sua obra carecem de estudo e análise? Que contribuições esta pesquisa poderia trazer para os estudos machadianos? Essas questões deram início e, de certa forma, acompanharam todo o desenrolar desta dissertação de mestrado.

Foi em uma aula de Literatura Brasileira IV, em 2009, que surgiu a ideia para esta pesquisa. Na ocasião, o professor Hélio de Seixas Guimarães, orientador deste trabalho, analisava o conto "O relógio de ouro". Entre outros tópicos interessantes, o professor comentou o final apaziguador que aparecia na primeira versão do texto, no Jornal das Famílias, final que foi retirado na versão em livro, modificando substancialmente o sentido do conto.

O professor também observou que a comparação sistemática das várias versões desses contos de início de carreira seria uma proposta pertinente de trabalho, que poderia trazer contribuições importantes para o entendimento do processo de criação de Machado de Assis tomando como base obras relativamente pouco estudadas.

Nessa mesma aula, alguns alunos, entre eles eu me incluo, possuíam uma cópia do conto "O relógio de ouro" retirada de uma página da internet, na qual, em vez de Tua Iaiá, aparecia a assinatura Tia Iaiá no bilhete da amante de Negreiros, erro que comprometia toda a lógica e compreensão do texto.

Podemos dizer que esse dia foi o início de duas preocupações que se mostraram urgentes; a primeira, de revisitar o universo de criação genética, pouco estudado em Machado; e a outra, oferecer um texto que possa ser facilmente localizado e acessado pelos novos meios tecnológicos, que seja confiável, fidedigno e que possa oferecer ao leitor o contato com as modificações que o escritor operou sobre o texto de uma versão para outra.

Depois de alguns encontros e pesquisas, surgiu o projeto de Iniciação Científica "Do Jornal das Famílias às Histórias da meia-noite: reescrita e criação nos primeiros contos de Machado de Assis", com o qual trabalhamos por 
dois anos com auxílio de bolsa PIBIC/CNPq. Nesse projeto, fizemos um levantamento das variantes nas duas versões dos contos, a do Jornal das Famílias e a da $1^{\mathrm{a}}$ edição do livro Histórias da meia-noite, e começamos a elaborar algumas hipóteses sobre o processo de criação desses textos.

Ao final da graduação, foi possível perceber que poderíamos continuar o desenvolvimento dessa pesquisa e elaborarmos uma edição crítico-genética virtual dos contos do livro Histórias da Meia-Noite ("A parasita azul", "As bodas de Luís Duarte", "Ernesto de Tal", "Aurora sem dia", "O relógio de ouro" e "Ponto de vista") comparando-os com os contos - alguns com títulos diferentes - inicialmente publicados no Jornal das Famílias, no período de 1870 a 1873.

Uma edição crítico-genética é aquela que mostra o percurso de criação do texto, com todas as suas variantes, ao mesmo tempo que oferece uma versão desse texto mais próxima da última vontade reconstituível do autor.

O objetivo desse trabalho é, portanto, ressaltar as mudanças, supressões e acréscimos realizados de uma versão para outra com a finalidade de começar a compreender os processos de criação subjacentes à reescrita dos contos. A dissertação consistirá também na reflexão crítica sobre o processo criativo de Machado de Assis a partir do cotejo das edições dos contos no Jornal das Famílias e no livro Histórias da meia-noite.

Além disso, todo esse conteúdo será disponibilizado em um site (hmn. fflch.usp.br) para facilitar o acesso a esses textos e a leitura deles. Discorreremos ainda sobre o caminho percorrido para a elaboração de uma edição virtual (e as implicações disso para a difusão e a recepção da obra machadiana) e buscaremos propor algumas bases teóricas e práticas para a realização desse tipo de edição.

No primeiro capítulo da dissertação, será apresentado um panorama dos dois momentos de publicação dos contos; jornal e livro.

No segundo capítulo, haverá a introdução crítico-filológica, juntamente com uma análise do caminho percorrido para a realização da edição virtual.

O terceiro capítulo consistirá da edição crítico-genética propriamente dita.

No quarto capítulo, faremos uma análise do percurso genético, tendo como tópicos:

- O processo de omissão

- O processo de adição

- O processo de substituição 
Por fim, terminaremos com algumas Considerações Finais que retomarão os principais pontos discutidos e acrescentarão mais algumas observações. 


\section{Capítulo 1}

\section{Jornal das Famílias e Histórias da meia-noite: dois momentos de publicação e recepção}

Neste trabalho, o contexto e a época em que as obras foram criadas e para quem se dirigiam são considerados itens essenciais para a análise. Entendemos que a produção machadiana resulta de uma determinada conjuntura, em uma determinada época. Para isso, faz-se necessário distinguir os dois momentos de publicação desses contos e o meio que os cercava, considerando que:

Os textos não existem fora dos suportes materiais (seja eles quais forem) de que são os veículos. Contra a abstração dos textos, é preciso lembrar que as formas que permitem sua leitura, sua audição ou sua visão participam profundamente da construção dos seus significados. O "mesmo" texto, fixado em letras, não é o "mesmo" caso mudem os dispositivos de sua escrita e de sua comunicação. (Chartier, $2002: 61-2$ )

Desse modo, devemos considerar que os contos publicados no Jornal das Famílias faziam parte de um contexto diferente daqueles publicados no livro Histórias da meia-noite e cada um desses textos tem uma especificidade própria sobre a qual devemos nos debruçar nessa nossa análise.

Como lembra Blecua Perdices (1983), com o invento da imprensa periódica, os escritores são obrigados, em certa medida, a se adequarem a um determinado espaço de páginas, escrever os textos com bastante antecedência e lidar com um público heterogêneo em circunstâncias ideológicas muitas vezes contraditórias. Alguns fatores, como a falta de correção 
das provas e a pressa em entregar os originais, ainda contribuem para a quantidade de erros na publicação periódica (Blecua Perdices, 1983: 227).

Blecua afirma que, muitas vezes, os escritores costumam reunir esses textos publicados no periódico em um livro e "[1]o normal en estos casos es que el texto sufra correcciones de una tipología muy amplia que no puede reducirse a la simple restitución del texto original" (Blecua Perdices, 1983 : 228). É o que parece acontecer no caso dos contos que serão analisados neste trabalho. As muitas alterações que são feitas de uma versão para outra são de natureza variada. Temos desde correções de eventuais erros tipográficos e alterações de parágrafos até mudança do foco narrativo.

Para analisar essas modificações com mais rigor, é preciso ter em mente também algumas particularidades de cada veículo onde esses textos foram publicados. Uma informação sobre a condição de publicação da época pode ilustrar e, de certa maneira, explicar, por exemplo, a quantidade de parágrafos e diálogos nos textos publicados no Jornal. Se pesquisarmos um pouco sobre como era feito o pagamento de um escritor de periódicos, ficamos sabendo que este recebia, muitas vezes, por linhas escritas, o que esclarece muita coisa. Esse tipo de questão fazia parte do universo do escritor e não pode ser deixada de lado, como lembra Ribeiro (1996):

[...]fica evidente que fatores de mercado condicionam a formação de um padrão de criação ficcional com o qual o escritor defronta-se obrigatoriamente no processo de elaboração de sua obra. (Ribeiro, 1996:11)

Devemos ter em consideração, portanto, as questões mais urgentes e materiais que Machado possa ter enfrentado enquanto escrevia esses contos. Havia uma necessidade básica de âmbito financeiro, havia pressões do tempo, do editor, da sociedade, regras e formatos a serem seguidos, os quais, de uma maneira ou de outra, acabaram influenciando o escritor e seus textos.

Quando pensamos no Machado consagrado de hoje, não podemos esquecer que ele também foi um escritor de folhetim (devendo, portanto, seguir o estilo de escrita próprio do gênero, com certa dose de subversão como iremos ver), praticante da "convenção estilística das leitoras de folhetins, em que os chavões idealizantes mascaravam uma conduta de classe perfeitamente utilitária" (Bosi, 1982:437).

Somando-se a isso, era necessário haver uma adequação da matéria escrita ao perfil do periódico. Sendo assim, algumas decisões como a simplificação dos personagens, o maniqueísmo, o romantismo exacerbado e a suspensão da narrativa eram elementos indispensáveis para a publicação de um texto no jornal (Hallewell, 2005 : 210). 
Outro dado muito relevante é a contextualização do público que lia esses textos. Guimarães (2004) nos oferece informações valiosas sobre o precário público de literatura do século XIX e sobre a dificuldade de produção e circulação dos bens culturais. Somos alertados, por exemplo, que, em 1872, 84\% da população era analfabeta e que uma tiragem de mil exemplares de um livro geralmente levava de 10 a 30 anos para se esgotar, quando se esgotava.

A leitura de folhetins em voz alta é outra característica a ser lembrada que também interferia na composição do texto, muitas vezes com a simplificação e a banalização das estruturas narrativas que "facilitariam o consumo oral por parte dos analfabetos que presenciavam os habituais serões de leitura" (Crestani, 2009: 53).

Podemos entender melhor como funcionava o Jornal consultando trabalhos como o de Pinheiro (2007) que reúne dados importantes sobre o Jornal das Famílias, periódico originário da Revista Popular e que foi um dos mais bem-sucedidos da época, com uma duração de 16 anos (de 1863 a 1878). O Jornal era composto principalmente por seções de moda, economia doméstica, receitas, bordados, assim como a seção Romances e novellas, na qual muitos contos de Machado de Assis foram publicados. Os conteúdos destinavam-se, majoritariamente, ao público feminino.

O periódico era impresso em Paris, com ilustrações ricas e trazia moldes de vestidos da última moda. Além do status de ser impresso em Paris, como lembra Hallewell (2005: 200-1), “[m]esmo pagando o custo do frete transatlântico, [...] o produto europeu era mais barato, além de sua melhor qualidade, tanto técnica quanto esteticamente, em relação ao feito no Rio de Janeiro". A assinatura para o Rio e Niterói custava $10 \$ 000$ e 12\$000 para as províncias, o que pode ser considerado um valor relativamente alto se pensarmos que o livro Crisálidas, de Machado de Assis, valia 1\$500 na época. A assinatura anual do Jornal também era mais cara do que um volume do importante dicionário de medicina popular que circulava no período (Pinheiro, 2007:62).

Outro dado interessante é que Garnier mantinha um leitor de provas em português em Paris (Hallewell, 2005: 200), o que nos faz pensar que o texto de Machado passaria a contar então com mais um mediador, mais um par de olhos para revisar e, quem sabe, até alterar o que havia sido escrito.

O livro Histórias da meia-noite, publicado em 1873, reúne 6 narrativas publicadas anteriormente no Jornal das Famílias ("A parasita azul", "As bodas de Luís Duarte", "Ernesto de tal", "Aurora sem dia", "O relógio de ouro" e "Ponto de vista").

Como nos lembra o mesmo Hallewell (2005: 206), os moldes dos contos de Histórias da meia-noite tiveram que ser recompostos para a impressão em 
livro, já que, em 1873, Garnier mantinha a Tipografia Franco-Americana no Rio de Janeiro e não imprimia mais os exemplares na França. Esse pode ser, talvez, um dos fortes motivos de Machado ter a oportunidade (ou a necessidade) de revisitar e modificar os seus textos antigos.

O mais comum, no caso de reimpressão de textos publicados anteriormente, era o reaproveitamento das formas nas quais os textos haviam sido impressos por questões práticas e econômicas. Por isso, era possível fazer apenas pequenas alterações e, muitas vezes, o tamanho da coluna do jornal determinava o tamanho do livro, ou vice-versa (Silva, 2010).

Hallewell (2005 : 204) afirma que a Tipografia Franco-Americana, com sede na rua do Ouvidor $\mathrm{n}^{\circ} 69$, funcionava com equipamentos e tipógrafos franceses, o que pode explicar muitos dos erros de impressão.

Sobre a publicação do livro, conseguimos encontrar duas notícias que também serão disponibilizadas no site $^{1}$ :

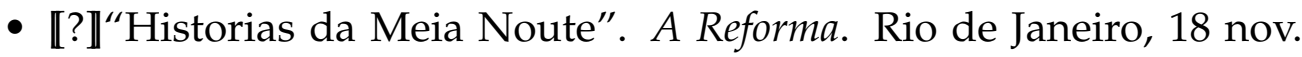
1873. Na seção Bibliographia, encontramos uma descrição do livro que não poupa elogios a Machado de Assis, "poeta mavioso e de uma correç̧ão admiravel". Apesar do equívoco de afirmar haver nove contos (logo remediado ao citar os nomes dos seis contos), a resenha descreve os textos como "alegres, espirituais e moraes". Não deixa de notar, com razão, que Machado de Assis não perde "a occasião que se lhe apresenta de censurar o lado ridiculo da sociedade que elle tão bem conhece, assim nada lhe escapa; nem o político do campanario, [...] nem o sestro litterario de um certo circulo, nem a educação em geral dada entre nós ás creanças, nem aquelles defeitos das moças a quem se não dá bons conselhos".

- ARAUCARIUS, pseud. [Joaquim Caetano Fernandes Pinheiro] "Litteratura Brazileira". O Novo Mundo. New York, n. 42, 23 mar. 1874. Na seção "Litteratura Brazileira", o jornal traz um conjunto de resenhas de obras que se destacaram no ano de 1873, entre elas, Histórias da meia-noite. Os contos são tratados como "verdadeiros esbocetos, repassados de candura e d'aquella naturalidade que fazem do illustre escriptor fluminense un digno emulo de Trueba".

Como ressaltamos anteriormente, é possível perceber que os contos do Jornal possuem certa especificidade e características peculiares próprias de seu veículo de publicação que, consequentemente, são diferentes das características do Livro. Como lembra Crestani (2009), desde a carta-programa do

\footnotetext{
${ }^{1}$ Em Assis (1975: 23-25), há uma lista de outros estudos referentes ao livro.
} 
Jornal das Famílias, podemos notar a preocupação com a "instrução moral" e a necessidade de escolher artigos e textos que se encaixassem nesse perfil:

Mais do que nunca dobraremos os nossos zelos na escolha dos artigos que havemos de publicar, preferindo sempre os que mais importarem ao país, à economia doméstica, à instrução moral e recreativa, à higiene, numa palavra, ao recreio e utilidade das famílias.(Jornal das Famílias, jan. 1863, p. 2-3. citado por Crestani $(2009: 60))$

Não podemos nos esquecer, como destaca Massa (1971:542), da "reduzida liberdade de ação dos colaboradores", que deveriam se encaixar nos padrões morais propostos pelo folhetim. Caso contrário, havia sempre a ameaça de cancelamento da assinatura por parte dos pagantes, com consequências negativas tanto para o editor quanto para o escritor.

Voltamos a pensar em como o escritor lidava com a importância de se adequar às exigências de mercado enquanto elaborava os contos. Essa questão não pode ser deixada de lado quando formos analisar o cotejo dos contos e as alterações entre as versões. Machado não estava desatento a essas questões, pelo contrário. Saraiva (2008), quando escreve sobre as mudanças realizadas em Quincas Borba da versão do folhetim para a do livro, ressalta a consciência de Machado sobre a importância de considerar o veículo onde o texto seria impresso e quem iria lê-lo:

As alterações revelam o ajuste paciente e laborioso do escritor que distingue, a partir do suporte material, peculiaridades do gênero de cada uma das publicações, que se interligam, por sua vez, à imagem do receptor. Consequentemente, a identificação do uso de procedimentos técnicos expõe a reflexão crítica do escritor que tem consciência de que a composição do texto não pode estar desvinculada das marcas de gênero e de sua materialidade. (Saraiva, $2008: 200$ )

Esperamos demostrar, com a análise da reescrita desses contos, que aqui também já podemos perceber uma faceta brilhante de Machado enquanto escritor crítico, consciente e atento para as particularidades dos gêneros e do público a que se dirigia.

Ao compararmos as condições de produção, é possível perceber que Machado, ao reescrever os seus contos e reuni-los no livro Histórias da meia-noite, alcança uma certa liberdade que não possuía ao publicá-los no Jornal, e, junto com ela, parece exercer e deixar transparecer alguns dos 
elementos que veríamos nas suas obras da maturidade. Não queremos dizer, no entanto, que as narrativas de Histórias da meia-noite podem ser equiparadas aos contos ou romances mais tardios; elas são mostras de um processo de amadurecimento do estilo e de adequação ao veículo no qual foram publicadas e devem ser analisadas no contexto em que foram escritas.

Tendo em mente que qualquer texto se inspira em outro texto anterior e que a originalidade do escritor tem as suas origens (Willemart, 1999:167), temos a possibilidade de, pela análise dessas primeiras produções, compreendermos melhor a gênese dos textos mais maduros do autor.

Além disso, a clássica divisão da obra de Machado de Assis em duas fases completamente distintas pode ser, de certa forma, relativizada, já que, como afirma França (2008), é possível constatar nessas produções iniciais problemas que seriam retomados, reelaborados e aprimorados posteriormente.

Portanto, por meio da análise dos cotejos dos contos, pretendemos demonstrar e elaborar hipóteses de como Machado de Assis desenvolvia a sua escrita e de que maneira a adaptava aos diferentes veículos e públicos, de modo a reconstruir o percurso genético desses contos.

Não há ainda uma edição genética do livro Histórias da meia-noite; aliás, a única edição crítico-genética das obras de Machado de Assis é a de Ana Cláudia Suriani da Silva, disponibilizada no livro Linha reta e linha curva: edição crítica e genética de um conto de Machado de Assis. A autora destaca, em seu estudo, a importância de se considerar a historicidade dos primeiros contos de Machado, a relação entre os leitores e o jornal e o tipo de público que vinha se formando na época:

Desta forma, estudar o conto machadiano da primeira fase na sua historicidade significa [...] reconhecê-lo na dinâmica do seu tempo, na qual se combinam aspectos da vida intelectual do escritor, o horizonte cultural em que a obra foi produzida, o leitor e a materialidade do texto na forma como foi recebido por seus contemporâneos (Silva, 2003: 23-4).

Outros estudiosos também notaram o esforço de adequação empreendido pelo escritor. Ao analisar as mudanças feitas por Machado de Assis em Memórias Póstumas de Brás Cubas, na passagem da revista para o livro, Ribeiro (2006 : 102) afirma que "[s]ão modificações que alteram o perfil do leitor ideal da revista para o livro. Revelam também, uma interferência da atmosfera do veículo, a revista, no processo de criação da obra". 
É por isso que, como já apontamos, neste projeto também pretendemos levar em conta o veículo de publicação de cada versão do conto, consequentemente, o tipo de público que cada publicação visava alcançar. Será importante considerar ainda que a produção, tanto do livro quanto do jornal, envolve uma coletividade de atores e que nem todas as mudanças foram, necessariamente, feitas por Machado de Assis:

[...] convém lembrar que a produção, não apenas de livros, mas dos próprios textos, é um processo que implica, além do gesto da escrita, diversos momentos, técnicas e intervenções, como as dos copistas, dos livreiros editores, dos mestres impressores, dos compositores e dos revisores.[...] O processo de publicação, seja lá qual for a sua modalidade, é sempre um processo coletivo que requer numerosos atores e não separa a materialidade do texto da textualidade do livro. (Chartier (2007:12-3) grifo do autor)

Pino \& Zular (2007:77) também destacam a necessidade de considerar aspectos externos à obra como os "modos de produção, circulação e recepção da escrita e [...] a partir do performativo, do universo discursivo em que cada texto opera, atentando para a ficcionalidade que percorre todo o processo".

Nesse sentido, o público leitor e o suporte em que o texto vem publicado são cruciais, como ressalta Guimarães (2004: 39):

Isso significa entender a recepção do texto literário não como fim de um processo, nem como algo externo ao texto e independente de sua produção, mas como algo do mundo objetivo que participa do processo de realização da obra.

No caso de Machado de Assis, em especial, podemos ver um escritor preocupado e atento a todo o universo da recepção dos seus textos. Machado dialogava com os seus "críticos" e leitores tanto por meio de Prefácios, Advertências e Cartas, quanto internamente, no próprio texto, como acontece, posteriormente, em Memórias Póstumas de Brás Cubas.

Para concluir, ao analisarmos essas mudanças de uma versão para outra, como exemplificaremos mais adiante, não podemos esquecer, como destaca Azevedo (1990:517) que esse período de reescrita foi importante para o escritor exercer e praticar a forma de se escrever contos, com o adensamento da narrativa e a tentativa de afastamento dos moldes românticos e melodramáticos. 


\section{Capítulo 2}

\section{Introdução crítico-filológica}

Para este projeto de edição crítico-genética, usaremos apenas as edições pertinentes (Guimarães, 1997), publicadas enquanto Machado de Assis estava vivo, onde podemos ter acesso à última vontade reconstituível do autor.

O termo "vontade" talvez não seja o mais adequado, pois, como já vimos na seção anterior, o escritor está sujeito a várias pressões de modo que não é tudo e só o que está escrito que manisfesta a sua "vontade". Além disso, como lembra Castro (2001), essa "intenção final do autor" pode ter ficado in petto e talvez nunca saberemos qual tenha sido. No entanto, esse é um termo bastante usado na área da Filologia e procederemos com o uso tendo em mente essas observações.

Não usaremos, neste momento, as edições póstumas, utilizadas pela Filologia como exemplares de variantes não-autorais. Não deixamos de considerar, no entanto, a importância dessas edições para o estudo da transmissão da obra de Machado de Assis.

Este trabalho também se distancia do método lachmanniano, muito útil na reconstituição de manuscritos antigos, mas que não se aplica ao tipo de texto que temos em mãos; com autoria reconhecida e sem problemas de fixação do texto.

A nossa edição de base será a $1^{\text {a }}$ Edição do livro Histórias da meia-noite, publicada em 1873, única em vida do autor, considerando que "o mais autorizado dos testemunhos é aquele que contém a última intenção do autor quanto à forma e à substância da sua obra" (Castro, 1990b).

Em se tratando de Edição Crítica, não podemos nos esquecer do trabalho realizado pela Comissão Machado de Assis, a partir de 1960, para o estabelecimento de critérios na preparação de uma Edição Crítica, o que foi de grande valia na sistematização desse novo campo de estudos no Brasil. Essa mesma Comissão preparou em 1975 uma Edição Crítica do 
livro Histórias da meia-noite.

A elaboração de uma nova edição se justifica pelo fato de que muitos erros foram encontrados na Edição Crítica elaborada pela Comissão Machado de Assis, desde informações imprecisas sobre o número da página em que o conto poderia ser localizado até incorreções no próprio cotejo entre as lições A (primeira redação pública no Jornal das Famílias) e B (primeira edição em livro). Além disso, o nosso projeto propõe a disponibilização desse trabalho em um suporte diferente - a internet - e pretende facilitar o entendimento e a visualização das variantes do texto com o uso de novas ferramentas para edição, além de aumentar a acessibilidade e a disponibilidade dessas edições.

Usamos o termo "edição crítico-genética" na acepção que Ivo Castro adota ao propor a Edição Crítica da Obra Completa de Fernando Pessoa; ou seja, "enquanto crítica, esta edição procura fixar um texto mais autorizado (isto é, mais próximo da vontade reconstituível do autor); enquanto genética, procura documentar o percurso seguido pelo autor na construção de cada texto" ( Castro (1990a:31) grifos do autor).

Embora usemos muitos dos conceitos que Ivo Castro desenvolve, é importante esclarecer a distância entre os trabalhos. Estamos lidando com autores, épocas, estilos e materiais distintos. O que a Equipa Pessoa faz para organizar os manuscritos de Fernando Pessoa é de um nível muito grande de complexidade e apresenta enormes desafios seja pelo tamanho do acervo, pela dificuldade de leitura, pela imprecisão de datas etc. Mesmo assim, podemos considerar que as experiências vividas e as dificuldades enfrentadas pela equipe são de muita ajuda na hora de elaborar uma edição crítico-genética de um autor moderno.

Como lembra Castro (1995), o estabelecimento de um texto consiste em transcrever os dados de origem autoral, substituir os erros (elementos não-autorais) por emendas, e reduzir, assim, as diferenças entre esse texto e o que o autor escreveu, dando condições ao leitor de ter acesso ao que realmente o autor teve intenção de escrever.

No entanto, o filólogo está sujeito a cometer erros, principalmente em quatro ocasiões listadas por Castro (1995:5-6): quando ele identifica o possível erro, quando faz a emenda desse erro, quando decodifica o original ( e neste caso, a expectativa do filólogo pode "forçar" o que o autor realmente escreveu) e quando escolhe o modo de representação da transcrição desse texto.

Do mesmo modo, deve-se tomar cuidado em não querer organizar uma edição a fim de provar hipóteses ou ideias que o crítico tenha e não que o texto necessariamente traga; é preciso ter "em igual consideração tudo o que os papéis dizem, mas nunca os forçando a dizer mais que aquilo 
que contêm. Não os escolher, não os adaptar ao nosso gosto, nem os espremer"(Castro, 1990a : 28).

Sabemos também que não se deve prometer resultados absolutos e definitivos ao estabelecer um texto. Ao analisarmos as edições que temos à mão, podemos examinar apenas uma parte do processo criativo, que é muito mais complexo e difícil de mapear e sobre o qual Machado nos deixou pouquíssimas informações. Além disso, pode ser que futuramente sejam encontrados manuscritos ou documentos que tragam mais informações sobre o processo e até mesmo invalidem o que hoje acreditamos ser o texto mais confiável. É preciso considerar, enfim, que "[n]enhuma edição crítica é mais que uma "proposta de trabalho", nenhuma encerra definitivamente a forma e a significação de um texto"(Castro, 1995 : 6-7).

Portanto, pretendemos oferecer uma proposta de edição baseada nos princípios teóricos e metodológicos acima referidos que contemple:

- Uma edição fac-similar digital, disponibilizada no site hmn.fflch. usp.br.

- Uma edição crítico-genética, com o aparato marcado no próprio texto, apresentada nesta dissertação e disponibilizada no site também.

- Uma edição "limpa", tendo como base a $1^{\text {a }}$ Edição do livro Histórias da meia-noite, disponibilizada no site.

\subsection{Normas e critérios adotados}

Para o estabelecimento do texto crítico, optamos pelas seguintes normas e critérios:

- Modernização e atualização da ortografia.

- Manutenção da pontuação, inclusive do uso da vírgula quando não estiver de acordo com as regras atuais, salvo raras exceções descritas conto a conto.

- Manutenção dos estrangeirismos e suas respectivas representações gráficas.

- Os erros tipográficos e eventuais erros do autor serão corrigidos na edição crítico-genética e virão acompanhados de uma nota de rodapé. Na edição "limpa" não haverá nota para esse tipo de erro, que já virá corrigido. 
- Manutenção do uso das formas "esse", "este" e derivados, "onde" e "aonde", mesmo quando esse uso for diferente nas regrais gramaticais atuais.

\subsection{Opções tipográficas}

Os títulos dos contos serão apresentados em negrito. O uso de itálico ficará o mais próximo possível da representação nos originais, assim como o uso das letras maiúsculas e minúsculas. A capitalização dos meses do ano, nas cartas do conto "Quem desdenha" / "Ponto de vista", por exemplo, apresenta oscilações que serão respeitadas e apresentadas como nos originais.

As adições feitas de uma versão para outra serão representadas pela cor azul e fonte sans-serif. Os trechos excluídos durante a reescrita serão mostrados em fonte menor e cor vermelha.

Os erros tipográficos e eventuais erros do autor serão chamados em nota de rodapé. Se o erro foi encontrado na versão do jornal, aparecerá a identificação $(J N)$, se o erro apareceu na versão em livro, haverá a identificação $(H M N)$.

A paragrafação é bem diferente entre as versões. Na versão do Jornal há uma abundância de parágrafos que serão representados pelo símbolo correspondente $\S$. Se estiverem em azul, representam uma adição. Se estiverem em vermelho, representam uma supressão (o que acontece na maioria dos casos).

Aproveitamos para lembrar que o leitor pode ter acesso a todo esse conteúdo original consultando o site $\mathrm{hmn}$. fflch.usp. br no qual estão disponíveis as versões do Jornal e do livro digitalizadas sem quaisquer alterações.

\subsection{Descrição dos testemunhos}

A disponibilização dos periódicos digitalizados foi possível graças a projetos que ganham força na área de digitalização de acervos e abertura ao público geral. Os contos "Aurora sem dia" e "A parasita azul" foram retirados do site do Acervo Digital da Biblioteca Pública do Estado do Rio de Janeiro $^{1}$. Os outros quatro contos foram retirados do site da Hemeroteca Digital Brasileira da Fundação Biblioteca Nacional ${ }^{2}$. Os documentos estão

\footnotetext{
${ }^{1}$ http://www.cultura.rj.gov.br/acervo-digital/

biblioteca-publica-do-estado-do-rio-de-janeiro-bpe

${ }^{2}$ http://memoria.bn.br/hdb/periodico.aspx
} 
Por uma nova forma de edição

em bom estado de visualização e não oferecem desafios ao estabelecimento do texto.

Os contos foram publicados no Jornal das Famílias nos seguintes períodos:

- "Aurora sem dia", novembro a dezembro de 1870, assinado por Victor de Paula.

- "A parasita azul", junho a setembro de 1872, assinado por Job.

- "Ernesto de tal", março a abril de 1873, assinado por J.J. e Job.

- "O relógio de ouro", abril a maio de 1873, assinado por Job.

- "As bodas do Dr. Duarte" (publicado com o título "As bodas de Luís Duarte", no livro), junho a julho de 1873, assinado por Lara.

- "Quem desdenha" (publicado com o título "Ponto de vista", no livro), outubro a novembro de 1873, assinado por Machado de Assis.

A primeira edição do livro Histórias da meia-noite, usada como edição de base, foi retirada do site da Brasiliana ${ }^{3}$, da Biblioteca Brasiliana Guita e José Mindlin - USP. O documento apresenta algumas páginas com dificuldade de visualização, portanto, também foi consultada uma edição em CD-ROM oferecida pelo IEB - Instituto de Estudos Brasileiros.

\subsection{Por uma nova forma de edição}

Todos nós sabemos que o desenvolvimento tecnológico oferece cada vez mais comodidade e facilidade para as tarefas do dia a dia. A velocidade e a interatividade se fazem presentes a um número cada vez maior de pessoas. No entanto, algumas áreas, como a que nos interessa em particular, parecem ainda pouco receptivas a essas tecnologias. Com tantos recursos disponíveis, a leitura, pesquisa e criação na área literária, com o uso de novas tecnologias, ainda são pouco favorecidas, principalmente no Brasil.

Enquanto podem ser encontrados projetos avançados no exterior no que diz respeito a bibliotecas virtuais, edições críticas etc., aqui no nosso país são poucos e com pouca divulgação os projetos e as pesquisas nessa área.

Megías (2009), um estudioso desse tema, traça um panorama geral e sistematiza o que vem sendo feito até agora no que se refere à edição

\footnotetext{
${ }^{3}$ http://www.brasiliana.usp.br/
} 
crítica hipertextual. Ele chama a atenção para a possibilidade de superar o chamado "incunable del hipertexto", ou seja, os primórdios do hipertexto, onde é explorada somente a capacidade mais evidente desse meio digital: a de armazenar uma grande quantidade de informação a um baixo custo, como acontece, por exemplo, nas bibliotecas virtuais.

As bibliotecas virtuais fac-similares são resultado do trabalho feito por grandes bibliotecas, europeias, americanas e também brasileiras, que digitalizaram alguns dos seus textos mais valiosos e raros, para facilitar o trabalho do pesquisador ou do interessado. Alguns exemplos são: British Library $^{4}$, Cambridge University Library ${ }^{5}$, Biblioteca Nacional de Portugal ${ }^{6}$, Biblioteca Nacional de España ${ }^{7}$, Bibliothèque Nationale de France ${ }^{8}$ entre outros.

Aqui no Brasil, temos também algumas bibliotecas virtuais que disponibilizam o acesso a livros, periódicos e manuscritos. Uma das mais conhecidas talvez seja o site Domínio Público ${ }^{9}$, onde é possível encontrar uma grande quantidade de livros, teses e dissertações, arquivos de áudio, imagens etc. de obras científicas, literárias e artísticas que sejam de domínio público ou que tenham a sua publicação autorizada. A própria Fundação Biblioteca Nacional oferece acesso a vários textos raros por meio da sua Biblioteca Nacional Digital do Brasil ${ }^{10}$, além de projetos contendo documentos sobre temas específicos como Guerra do Paraguai, Brasil e Estados Unidos, Tráfico de Escravos no Brasil etc. O Projeto Brasiliana USP $^{11}$, da Universidade de São Paulo, também está promovendo o acesso livre a textos, mapas, livros, periódicos, articulando instituições públicas e privadas para a formação e divulgação de acervos.

No entanto, esses tipos de bibliotecas, apesar da inquestionável importância e utilidade, não vão muito além do armazenamento de informações, não permitem uma interatividade do leitor com o que está na tela.

Hoje, já há a possibilidade de pensarmos em um tipo de edição capaz de comunicar e disponibilizar imagens, dados, textos e leituras, sincronizados e simultâneos, de uma maneira difícil de se imaginar há algum anos. Isso pode ser visto, por exemplo, na edição eletrônica virtual variorum de

\footnotetext{
${ }^{4}$ http: //www.bl.uk

${ }^{5}$ http://www.lib.cam.ac.uk

${ }^{6}$ http: //www . bnportugal.pt

${ }^{7}$ http: //www . bne.es

${ }^{8}$ http://www.bnf.fr

${ }^{9}$ http://www.dominiopublico.gov.br

${ }^{10}$ http://bndigital.bn.br

${ }^{11}$ http: //www . brasiliana.usp.br
} 
D.Quixote, do Projeto Cervantes ${ }^{12}$. O Projeto Cervantes desenvolvido na Texas A\&M University, no Departamento de Estudios Hispánicos, é uma iniciativa que conta com vários colaboradores e com o apoio da iniciativa privada e de Universidades que desenvolvem ferramentas informáticas e editores de texto os quais possibilitam a realização do trabalho.

Os objetivos desse Projeto incluem a publicação na Internet da Cervantes International Bibliography Online, e do Anuario Bibliográfico Cervantino, as primeiras bibliografias completas de estudos, edições e traduções das obras de Cervantes. O Projeto ainda prevê a publicação de edições eletrônicas da obra completa de Cervantes, com ferramentas de busca variadas e a criação de um arquivo digital de imagens fotográficas sobre a época e as obras de Cervantes que seja útil para o ensino e pesquisa.

Parte desse trabalho já está pronta, como a edição variorum de Dom Quixote disponível para consulta gratuita na Internet. O grupo de pesquisadores do Projeto Cervantes faz uso do MVED (the Multi Variant Document Editor), um software capaz de ajudá-los a fazer o collatio das várias edições, nas etapas de identificação, análise e edição das variantes.

Como destacam os pesquisadores (Furuta et al., 2001), "[the MVED] provides the facility to compare and edit multiple documents simultaneously, with provisions to associate annotations and emendations". Esse programa permite o cotejo automático de variantes, a classificação dessas diferenças, a emenda e anotação nos textos e a visualização de imagens e textos simultaneamente. Uma opção bem interessante é a de poder classificar as variantes como erros de impressão, variante ortográfica, erro tipográfico, etc.

Outra ferramenta muito interessante que foi desenvolvida é o VERI (Virtual Editing-Reading Interface), uma interface online que permite a navegação e a busca de textos e imagens nessa coleção. O usuário pode escolher entre a leitura da transcrição, a visualização do original, qual edição ou cópia quer ver etc.

Urbina et al. (1999) explicam o funcionamento da edição eletrônica virtual variorum de D.Quixote (EEVV-DQ). Eles propõem, basicamente, três passos para a realização do trabalho. Primeiramente, faz-se necessária a aplicação de técnicas para o melhoramento de imagens para a adequada visualização do conteúdo dos textos, incluindo a correção de manchas, cortes, imperfeições, etc. Outro passo importante é a criação de um programa de OCR baseado na tipografia das edições antigas e que permita a digitalização automática dessas edições. Finalmente, é necessário o desenvolvimento de programas e sistemas para a produção de edições virtuais

\footnotetext{
${ }^{12} \mathrm{http}: / /$ cervantes.tamu.edu/V2/CPI/index.html
} 
múltiplas a partir da edição variorum; o que inclui o cotejo automático dos textos, correção de erros, criação de links relacionando textos, variantes e comentários editoriais e ainda a criação de instrumentos de composição e visualização que permitam a produção de: a) uma edição "alpha" variorum; b) múltiplas edições virtuais "beta" feitas por leitores individuais e segundo a seleção das variantes incorporadas; e c) várias edições críticas incorporando variantes e comentários individuais de um ou mais membros da equipe editorial.

Outro projeto bem interessante é a Edição crítica das obras e cartas de Nietzsche, da Association HyperNietzsche. No site Nietzsche Source ${ }^{13}$, é possível começar o percurso escolhendo visualizar a Edição Crítica Digital Alemã das obras completas de Nietzsche ou então optar pela visualização fac-similar das primeiras obras e manuscritos do autor, assim como cartas e documentos biográficos.

A Edição Crítica Digital das obras completas de Nietzsche, editada por Paolo D'Iorio, tem como base aquela feita por Giorgio Colli e Mazzino Montinari. Por meio de cotejos realizados por filólogos, cada palavra do texto digitalizado foi comparada com a versão impressa e as numerosas correções filológicas foram incorporadas diretamente ao texto eletrônico. Além disso, há ferramentas que facilitam a busca e a citação dos trechos; por exemplo, cada capítulo ou fragmento possui um endereço eletrônico exclusivo e as siglas utilizadas na URL correspondem às abreviações da edição impressa. De tal modo, a primeira seção de $O$ Anticristo, por exemplo, pode ser obtida pelo seguinte endereço: http://www .nietzschesource.org/eKGWB/AC-1. Esse é um avanço considerável, já que um dos problemas das edições eletrônicas é a dificuldade de localização e referência em pesquisas acadêmicas.

Outro exemplo bem interessante é o site ${ }^{14}$ que reúne a transmissão textual de Ilíada e Odisseia sob um perspectiva histórica e capaz de contextualizar essa transmissão sincrônica ou diacronicamente. O curioso é que, diferentemente da edição impressa que oferece a reconstrução do texto original como se ele existisse de tal modo naquela época, o projeto Homer Multitext permite a reconstrução das diferentes variantes dos textos tal como existiram em épocas e lugares distintos.

Há também projetos na área de Edição Genética, como a Edição genética comentada de "Time passes", de Virginia Woolf, elaborada pela equipe da Woolf Online ${ }^{15}$. Esse projeto se desenvolve a partir da análise genética

\footnotetext{
${ }^{13}$ http://www. nietzschesource.org

${ }^{14}$ http: //www . homermultitext.org

${ }^{15}$ http: //woolfonline.com
} 
do trecho "Time passes", que forma a sequência central do livro To the lighthouse. A Edição Genética de "Time passes" inclui 7 variantes distintas do texto. É possível explorar os vários estágios de composição da obra, desde o rascunho inicial, as páginas datilografadas, as provas corrigidas e as edições impressas. Todos esses documentos estão disponíveis por meio de imagens escaneadas e/ou transcrições.

Além desse valioso material, o site oferece outras ferramentas complementares para o estudo da obra e vida da autora. Ao selecionar a opção Contextual, o visitante pode mergulhar no período de criação do manuscrito (entre 30 de Abril e 25 de Maio, 1926), conhecer as pessoas e lugares que inspiraram a autora, ver fotografias e ler o diário (concentrado em Agosto de 1905), de Virginia Woolf.

Há, ainda, uma seção com material bibliográfico utilizado dentro do site e uma lista de leituras recomendadas para quem quiser se aprofundar no assunto. A seção Image Galleries oferece um grande número de imagens e fotografias referentes ao período de criação do manuscrito, à família da autora e as impressões e marcas que a casa Talland (onde a autora passou sua infância e se inspirou para escrever "Time Passes") deixou na escrita de Woolf.

Recentemente, foi lançada a edição digital dos panfletos de Eulálio Motta $^{16}$, feita pelo prof. Patrício Nunes Barreiros, da Universidade Estadual de Feira de Santana e da Universidade do Estado da Bahia.

Essa hiperedição reúne, além dos textos propriamente ditos, uma rica documentação paratextual de cartas, datiloscritos, fotografias, cartões, anotações com variados recursos de zoom, hipertexto e animação.

Em uma mesma página, podemos ter acesso ao fac-símile, à transcrição linear, à edição crítica, à transcrição sobreposta ao fac-símile, à transcrição com links e à versão para impressão, além de informações sobre a descrição do manuscrito e o seu paratexto. São tantas informações em um mesmo espaço de modo que seria impossível reunir todos esses recursos em uma edição impressa, por exemplo.

Do mesmo modo, não podíamos deixar de comentar sobre o portal ${ }^{17}$ coordenado pela profa. Marta de Senna que reúne a revista eletrônica Machado de Assis em Linha, um banco de dados sobre citações e alusões na obra machadiana e ainda Edições em hipertexto de contos e romances de Machado.

Esses projetos foram alguns dos que mais nos inspiraram e nos orientaram em como desenvolver a nossa edição crítico-genética virtual, dentro

\footnotetext{
${ }^{16}$ http: //www. eulaliomotta.com.br

17 http://www. machadodeassis.net
} 
dos recursos que tínhamos à mão.

Logo que decidimos elaborar uma edição virtual, ficou definido que procuraríamos utilizar apenas programas gratuitos e acessíveis a qualquer pessoa. Começando pelo sistema operacional (Ubuntu 12.04) do qual fizemos uso e chegando ao próprio site, a nossa procura foi sempre por software livre.

Para compensar a falta de conhecimento técnico, este trabalho contou com a ajuda valiosa do funcionário da STI (Seção Técnica de Informática) da FFLCH, Thiago Gomes Veríssimo. Ele sugeriu o uso do Drupal, um sistema de gerenciamento de conteúdo (CMS), para a construção do site. Por meio do Thiago, também, o site ganhou hospedagem, domínio e servidor dentro da própria Faculdade.

Foi igualmente essencial participar do curso LATEXpara Linguistas, oferecido pelo Departamento de Linguística na Faculdade. Por meio do curso, foi possível conhecer e começar a utilizar essa ferramenta muito útil na elaboração das edições e da própria dissertação.

Como já foi descrito no início do capítulo, tivemos acesso aos contos do Jornal das Famílias por meio da internet. Para salvá-los no computador, foi necessário selecioná-los um a um e copiá-los para pastas correspondentes. No entanto, como de praxe, as imagens eram salvas em .jpeg o que impossibilitava a busca por palavras, por exemplo. Nossos esforços se voltaram, então, para a tentativa de transformar as imagens em texto pesquisável. Usando o programa Abby Fine Reader Sprint, foi possível converter os arquivos para .pdf pesquisável e depois juntá-los, conto a conto, por meio do programa PDF Split and Merge.

A $1^{\text {a }}$ Edição do livro, do site da Brasiliana, já oferecia a possibilidade de busca por palavras, mas por ser protegida por senha, não era possível dividir o livro conto a conto. Por e-mail, foi solicitada ajuda aos técnicos da Brasiliana e eles enviaram uma cópia destravada que resolveu o problema.

Outro ponto a ser lembrado é que o OCR (reconhecimento ótico de caracteres) que faz as buscas por palavras apresenta um índice razoável de acertos, mas não é infalível. Quando for digitar o que deseja procurar, o usuário também deve atentar que, nos originais, deve ser utilizada a ortografia do século XIX.

Os textos dos contos foram digitados e editados no programa TexStudio, que utiliza a linguagem Tex e o cotejo foi facilitado pelo script em Perl latexdiff, opção CFONT, que faz a comparação entre dois documentos .tex e mostra os resultados em um novo documento com as adições em cor azul e fonte sans-serif e as omissões em cor vermelha e fonte menor. Depois desse processo automático, foi necessário uma revisão manual para adequar melhor a posição das alterações no texto e corrigir possíveis equívocos. 
Todo esse material foi compilado em PDF, no próprio TexStudio. Como já alertava Cambraia (2005:179) sobre a questão de incompatibilidade de programas que abram os arquivos de texto, optamos pelo uso da extensão .pdf para salvar os textos, atualmente, uma das mais seguras, compatíveis e utilizadas no mundo.

O site, como já explicamos, foi construído por meio da plataforma Drupal e possui interface simples e intuitiva. Quando entra no site, o usuário pode escolher, na parte esquerda da tela, a qual conto e versão deseja ter acesso. Para poder visualizar os documentos na tela, é preciso que ele tenha em seu navegador o programa Adobe Reader, que pode ser baixado gratuitamente ${ }^{18}$. Caso prefira, pode também fazer o download, ler os textos em seu computador ou imprimi-los.

${ }^{18}$ http://get .adobe.com/br/reader/ 


\section{Capítulo 3}

\section{Edição crítico-genética}

\section{1 "A parasita azul"}

\section{A parasita azul}

I.

\section{Volta ao Brasil}

Há coisa de alguns cerca de dezesseis anos, desembarcava no Rio de Janeiro, vindo de da Europa, o Sr. Camilo Seabra, goiano de nascimento, que ali fora estudar medicina e voltava agora com o diploma na algibeira e umas saudades no coração. Voltava depois de uma ausência de oito anos, tendo visto e admirado as principais coisas que um homem pode ver e admirar por lá, quando não lhe falta gosto nem meios. Ambas as coisas possuía, e se tivesse também, não digo muito, mas um pouco mais de juízo, haveria houvera gozado melhor do que gozou, e com justiça poderia dizer que vivera.

Não abonava muito os seus sentimentos patrióticos o rosto com que entrou a barra da capital brasileira. Trazia-o fechado e merencório, como quem abafa em si alguma coisa que não é precisamente exatamente a bemaventurança terrestre. Arrastou um olhar aborrecido pela cidade, que se ia desenrolando à proporção que o navio se dirigia ao ancoradouro. Quando veio a hora de desembarcar fê-lo com a mesma alegria com que o réu ${ }^{1}$ penetra transpõe os umbrais do cárcere. O escaler afastou-se do navio em cujo mastro flutuava uma bandeira tricolor; o Camilo murmurou consigo:

- Adeus, França!

Depois envolveu-se num magnífico silêncio e deixou-se levar para terra.

\footnotetext{
${ }^{1} J F$ céu
} 
O espetáculo da cidade, que ele não via há tanto tempo, sempre lhe prendeu um pouco a atenção. Não tinha porém dentro da alma o alvoroço de Ulisses ao ver a terra da sua pátria. Era antes pasmo e tédio. Comparava o que via agora com o que vira durante longos anos, e sentia a mais e mais apertar-lhe o coração a dolorosa saudade que o minava. Encaminhou-se para o primeiro hotel que lhe pareceu conveniente, e ali determinou passar alguns dias, antes de seguir para Goiás. Jantou solitário e triste com a mente cheia de mil recordações do mundo que acabava de deixar, e para dar ainda mais maior desafogo à memória, apenas acabado o jantar, estendeuse num canapé, e começou a desfiar consigo mesmo um rosário de cruéis desventuras.

Na opinião dele, nunca houvera mortal que mais dolorosamente experimentasse a hostilidade do destino. Nem no martirológio cristão, nem nos trágicos gregos, nem no livro de Jó havia sequer um pálido esboço dos seus infortúnios. Vejamos alguns traços patéticos da existência do nosso herói.

Nascera rico, filho de um proprietário de Goiás, que nunca vira outra terra além da sua província natal. Em 1828 estivera ali um naturalista francês, com quem o comendador Seabra travou relações, e de quem se fez tão amigo, que não quis outro padrinho para o seu único filho, que então contava um ano de idade. O naturalista, muito antes de o ser, cometera umas venialidades poéticas que mereceram alguns elogios em 1810, mas que o tempo, - velho trapeiro da eternidade, - levou consigo para o infinito depósito das coisas inúteis. Tudo lhe perdoara o ex-poeta, menos o esquecimento de um poema em que ele metrificara a vida de Fúrio Camilo, poema que ainda então lia com sincero entusiasmo. Como lembrança desta obra da juventude, chamou ele ao afilhado Camilo, e com esse nome o batizou o padre Maciel, a grande aprazimento da família e seus amigos.

- Compadre, disse o comendador ao naturalista, se este pequeno vingar, hei de mandá-lo para sua terra, a aprender medicina ou qualquer outra coisa em que se faça homem. No caso de lhe achar jeito para andar com plantas e minerais, como o senhor, não se acanhe; dê-lhe o destino que lhe parecer como se fora seu pai, que o é, espiritualmente falando.

- Quem sabe se eu viverei nesse tempo? disse o naturalista.

— Oh! há de viver! protestou Seabra. Esse corpo não engana; a sua têmpera é de ferro. Não o vejo eu andar todos os dias por esses matos e campos, indiferente a sóis e a chuvas, sem nunca ter a mais leve dor de cabeça? Com metade dos seus trabalhos já eu estava defunto. Há de viver e cuidar do meu rapaz, apenas ele tiver concluído cá os seus primeiros estudos.

A promessa de Seabra foi pontualmente cumprida. Camilo seguiu para Paris, logo depois de alguns preparatórios, e ali o padrinho cuidou dele 
como se realmente fora seu pai. O comendador não poupava dinheiro para que nada faltasse ao filho; a mesada que lhe mandava podia bem servir para duas ou três pessoas em iguais circunstâncias. Além da mesada, recebia ele por ocasião da Páscoa e do Natal amêndoas e festas que a mãe lhe mandava, e que lhe chegavam às mãos debaixo da forma de alguns excelentes mil francos.

Até aqui o único ponto negro na existência de Camilo, era o padrinho, que o trazia peado, com receio de que o rapaz viesse a perder-se nos precipícios da grande cidade. Quis, porém, a sua boa estrela que o expoeta de 1810 fosse repousar no nada ao lado das suas produções extintas, deixando na ciência alguns sérios vestígio da sua passagem por ela. Camilo apressou-se a escrever ao pai uma carta cheia de reflexões filosóficas, algumas delas tão profundas, que o padre Maciel não duvidou honrá-las inserindo-as no seu próximo sermão.

O período final dizia assim:

"Em suma, meu pai, se lhe parece que eu tenho o necessário juízo para concluir aqui os meus estudos, e se tem confiança na boa inspiração que me há de dar a alma daquele que lá se foi deste vale de lágrimas para gozar a infinita bem-aventurança, deixe-me cá ficar até que eu possa regressar ao meu país como um cidadão esclarecido e apto para o servir, como é do meu dever. Caso a sua vontade seja contrária a isto que lhe peço, diga-o com franqueza, meu pai, porque então não me demorarei um instante mais nesta terra, que já foi meia pátria para mim, e que hoje (hélas!) é apenas uma terra de exílio."

O bom velho não era homem que pudesse ler ver por entre as linhas desta lacrimosa epístola o verdadeiro sentimento que a ditara. Chorou de alegria ao ler as palavras do filho, mostrou a carta a todos os seus amigos, e apressou-se a responder ao rapaz que podia ficar em Paris todo o tempo necessário para completar os seus estudos, e que, além da mesada que lhe dava, nunca the recusaria tudo quanto lhe fosse indispensável em circunstâncias imprevistas. Além disto, aprovava de coração os sentimentos que ele manifestava em relação à sua pátria e à memória do padrinho. Transmitia-lhe muitas recomendações do tio Jorge, do padre Maciel, do coronel coronel Veiga, de todos os parentes e amigos, e concluía deitando-lhe a benção.

A resposta paterna chegou às mãos de Camilo no meio de um almoço, que ele dava no café Café de Madrid a dois ou três estroinas de primeira qualidade. Esperava aquilo mesmo, mas não resistiu ao desejo de beber à saúde do pai, ato em que foi acompanhado pelos elegantes milhafres seus amigos. Nesse mesmo dia planeou Camilo algumas circunstâncias imprevistas (para o comendador) e o próximo correio trouxe para o Brasil uma extensa carta em que o jovem Camilo ele agradecia as boas expressões 
"A parasita azul"

do pai, dizia-lhe suas saudades, confiava-lhe as suas esperanças, e pedia respeitosamente, em post-scriptum, a remessa de uma pequena quantia de dinheiro.

Graças a estas facilidades atirou-se o nosso Camilo a uma vida solta e dispendiosa, não tanto, porém, que lhe sacrificasse todos os estudos. A inteligência que possuía, e certo amor próprio que não perdera, muito o ajudaram neste lance; concluído o curso, foi examinado, aprovado e doutorado.

A notícia do acontecimento foi transmitida ao pai com o pedido de uma licença para ir ver outras terras da Europa. Obteve a licença, e saiu de Paris para visitar a Itália, a Suíça, a Alemanha e a Inglaterra. No fim de alguns meses estava outra vez na grande capital, e aí reatou o fio da sua antiga existência, já livre então de cuidados estranhos e aborrecidos. A escala toda dos prazeres sensuais e frívolos foi percorrida por este esperançoso mancebo com uma sofreguidão que parecia antes suicídio. Seus amigos eram numerosos, solícitos e constantes; alguns não duvidavam dar-lhe a honra de o constituirem constituir seu credor. Entre as moças de Corinto era o seu nome verdadeiramente popular; não poucas o tinham amado até o delírio. Não havia pateada célebre em que a chave dos seus aposentos não figurasse, nem corrida, nem ceata, nem passeio, em que não ocupasse um dos primeiros lugares cet aimable brésilien.

Desejoso de o ver, escreveu-lhe o comendador pedindo que regressasse ao Brasil; mas o filho, parisiense até a medula dos ossos, não compreendia que um homem pudesse sair do cérebro da França para vir internar-se em Goiás. Respondeu com evasivas e deixou-se ficar. O velho fez vista grossa a esta primeira desobediência. Tempos depois insistiu em chamá-lo; novas evasivas da parte de Camilo. Irritou-se o pai e a terceira carta que lhe mandou foi já de amargas censuras. Camilo caiu em si e dispôs-se com grande mágoa a regressar à pátria, não sem esperanças de voltar a acabar os seus dias no boulevard do Italianos ou à porta do café Café Helder.

Um incidente, porém, demorou ainda desta vez o regresso do jovem médico. Ele, que até ali vivera de amores fáceis e paixões de uma hora, veio a enamorar-se repentinamente de uma linda princesa russa. Não se assustem; a princesa russa de quem falo, afirmavam algumas pessoas que era filha da rua do Bac e trabalhara numa casa de modas, até a revolução de 1848. No meio do trovão popular da revolução apaixonou-se por ela um major polaco, que a levou para Varsóvia, donde acabava de chegar transformada em princesa, com um nome acabado em ine ou em off, não sei bem. Vivia misteriosamente, zombando de todos os seus adoradores, exceto de Camilo, dizia ela, por quem sentia que era capaz de aposentar as suas roupas de viúva. Tão depressa, porém, soltava estas expressões irrefletidas, como 
logo protestava com os olhos no céu:

- Oh! não! nunca, meu caro Alexis, nunca desonrarei a tua memória unindo-me a outro.

Isto eram punhais que dilaceravam o coração de Camilo. O jovem médico jurava por todos os santos do calendário latino e grego que nunca amara a ninguém como à formosa princesa. A bárbara senhora parecia às vezes disposta a crer nos protestos de Camilo; outras vezes porém abanava a cabeça e pedia perdão à sombra do venerado príncipe Alexis. Neste meio tempo chegou uma carta decisiva do comendador. $\mathrm{O}$ velho goiano intimava pela última vez ao filho que voltasse, sob pena de lhe suspender todos os recursos e trancar-lhe a porta.

Não era possível tergiversar mais. Imaginou ainda uma grave moléstia; mas a ideia de que o pai podia não acreditar nela e suspender-lhe realmente os meios, aluiu de todo este projeto. Camilo nem ânimo teve de ir confessar a sua posição à bela princesa; receava além disso que ela, por um rasgo de generosidade, - natural a quem ama,- quisesse dividir com ele as suas terras de Novogorod. Aceitá-las seria humilhação, recusá-las poderia ser ofensa. Camilo preferiu sair de Paris deixando à princesa uma carta em que lhe contava singelamente os acontecimentos e prometia voltar algum dia se o destino o favorece.

Tais eram as calamidades com que o destino quisera abater o ânimo de Camilo. Todas elas repassou na memória o infeliz viajante, até que ouviu bater oito horas da noite. Saiu um pouco para tomar ar, e ainda mais se lhe acenderam as saudades de Paris. Tudo lhe parecia lúgubre, acanhado, mesquinho. Olhou com desdém olímpico para todas as lojas da rua do Ouvidor, que lhe pareceu apenas um beco muito comprido e muito iluminado. Achava os homens deselegantes, as senhoras desgraciosas. Lembrou-se, porém, que Santa Luzia, sua cidade natal, era ainda menos parisiense que o Rio de Janeiro, e então, abatido com esta importuna ideia correu para o hotel e deitou-se a dormir.

No dia seguinte, logo depois do almoço, foi à casa do correspondente de seu pai. Declarou-lhe que tencionava seguir dentro de quatro ou cinco dias para Goiás, e recebeu dele os necessários recursos, segundo as ordens já dadas pelo comendador. O correspondente acrescentou que estava incumbido de lhe facilitar tudo o que quisesse no caso de desejar passar algumas semanas na corte.

- Não, respondeu Camilo; nada me prende à corte, e estou ansioso por me ver a caminho.

— Imagino as saudades que há de ter. Há quantos anos?

- Oito.

— Oito! Já é uma ausência longa. 
Camilo ia-se dispondo a sair, quando viu entrar um sujeito alto, magro, com um pouco de alguma barba embaixo do queixo e bigode, vestido com um paletó de brim pardo e trazendo na cabeça um chapéu de Chile. O sujeito olhou para Camilo, estacou, recuou um passo, e depois de uma razoável hesitação, exclamou:

- Não me engano! é o senhor sr. Camilo!

- Camilo Seabra, com efeito, respondeu o filho do comendador, lançando um olhar interrogativo ao dono da casa.

- Este senhor, disse o correspondente, é o senhor Soares sr. Soares, filho do negociante do mesmo nome, da cidade de Santa Luzia.

- Quê! é o Leandro que eu deixei apenas com um buço...

- Em carne e osso, interrompeu Soares; é o mesmo Leandro que lhe aparece agora todo barbado, como o senhor, que também está com uns bigodes bonitos!

- Pois não o conhecia...

- Conheci-o eu apenas o vi, apesar de o achar muito mudado do que era. Está agora um moço apurado. Eu é que estou velho. Já cá estão vinte e seis... Não se ria: estou velho. Quando chegou?

- Ontem.

- E quando segue viagem para Goiás?

- Espero o primeiro vapor de Santos.

- Nem de propósito! Iremos juntos.

— Como está seu pai? Como vai toda aquela gente? O padre Maciel? O Veiga? Dê-me notícias de todos e de tudo.

- Temos tempo para conversar à vontade. Por agora só lhe digo que todos vão bem. O vigário é que esteve dois meses doente de uma febre maligna e ninguém pensava que arribasse; mas arribou. Deus nos livre que o homem adoeça, agora que estamos com o Espírito Santo à porta.

- Ainda se fazem aquelas festas?

- Pois então! O imperador este ano, é o coronel coronel Veiga; e diz que quer fazer as coisas com todo o brilho. Já prometeu que daria um baile. Mas nós temos tempo de conversar, ou aqui ou em caminho. Onde está morando?

Camilo indicou o hotel em que se achava, e despediu-se do comprovinciano, satisfeito de haver encontrado um companheiro que de algum modo lhe diminuísse os tédios de tão longa viagem. Soares chegou à porta e acompanhou com os olhos o filho do comendador até perdê-lo de vista.

- Veja o senhor o que é andar por essas terras estrangeiras, disse ele ao correspondente, que também chegava à porta. Que mudança fez aquele rapaz, que era pouco mais ou menos como eu! 


\section{Para Goiás}

Daí a dias seguiam ambos para Santos, de lá para S. Paulo e tomavam a estrada de Goiás.

Soares, à medida que ia reavendo a antiga intimidade com o filho do comendador, contava-lhe as memórias da sua vida, durante os oito anos de separação, e, à falta de coisa melhor, era isto o que entretinha o médico nas ocasiões e lugares em que a natureza lhe não oferecia algum espetáculo dos seus. Ao cabo de umas quantas léguas de marcha estava Camilo informado das rixas eleitorais de Soares, das suas aventuras na caça, das suas proezas amorosas, e de muitas coisas mais, umas graves, outras fúteis, que Soares narrava com igual entusiasmo e interesse.

Camilo não era espírito observador; mas a alma de Soares andava-lhe tão patente nas mãos, que era impossível deixar de a ver e examinar. Não lhe pareceu mau rapaz; notou-lhe porém, certa fanfarronice, em todo o gênero de coisas, na política, na caça, no jogo, e até nos amores. Neste último capítulo havia um parágrafo sério; era o que dizia respeito a uma moça, que ele amava loucamente, de tal modo que prometia aniquilar a quem quer que ousasse levantar olhos para ela.

- E o que lhe digo, Camilo, confessava o filho do comerciante, se alguém tiver o atrevimento de pretender essa moça pode contar que há no mundo mais dois desgraçados, ele e eu. Não há de acontecer assim felizmente; lá todos me conhecem; sabem que não cochilo para executar o que prometo. Há poucos meses o major Valente perdeu a eleição só porque teve o atrevimento de dizer que ia arranjar a demissão do juiz municipal. Não arranjou a demissão, e por castigo tomou taboca; saiu na lista dos suplentes. Quem lhe deu o golpe fui eu. A coisa foi...

- Mas por que não se casa com essa moça? perguntou Camilo desviando cautelosamente a narração da última vitória eleitoral de Soares.

- Não me caso porque... tem muita curiosidade de o saber !?

- Curiosidade... de amigo e nada mais.

- Não me caso porque ela não quer.

Camilo estacou o cavalo.

- Não quer? disse ele espantado. Nesse caso, Então por que motivo pretende impedir que ela...

— Isso é uma história muito comprida. A Isabel...

- Isabel?... interrompeu Camilo. Ora espere, será a filha do Dr. Matos, que foi juiz de direito há dez anos?

- Essa mesma. 
- Deve estar uma moça !?

- Tem seus vinte anos bem contados.

- Lembra-me que era bonitinha aos doze.

— Oh! mudou muito... para melhor! Ninguém a vê que não fique logo com a cabeça voltada. Tem rejeitado já uns poucos de casamentos. O último noivo recusado fui eu. A causa por que me recusou foi ela mesma que me veio dizer.

- E que causa era?

- "Olhe, Sr. Soares(, disse-me ela). O senhor merece bem que uma moça o aceite por marido; eu era capaz disso, mas não o faço porque nunca seríamos felizes."

- Que mais?

- Mais nada. Respondeu-me apenas isto que lhe acabo de contar.

- Nunca mais se falaram?

- Pelo contrário, falamo-nos muitas vezes. Não mudou comigo; tratame como dantes. A não serem aquelas palavras que ela me disse, e que ainda me doem cá dentro, eu ainda tinha podia ter esperanças. Vejo, porém, que seriam inúteis; ela não gosta de mim.

- Quer que lhe diga uma coisa com franqueza?

- Diga.

- Parece-me um grande egoísta.

- Pode ser; mas sou assim. Tenho ciúmes de tudo, até do ar que ela respira. Eu, se a visse gostar de outro, e não pudesse impedir o casamento, mudava de terra. O que me vale é a convicção que tenho de que ela não há de gostar nunca de outro, e assim pensam todos os mais.

- Não admira que não saiba amar, reflexionou Camilo pondo os olhos no horizonte como se estivesse ali a imagem da formosa súdita do tzar. Nem todas receberam do céu esse dom, que é o verdadeiro distintivo dos espíritos seletos. Algumas há porém, que sabem dar a vida e a alma a um ente querido, que lhe enchem o coração de profundos afetos, e deste modo fazem jus a uma perpétua adoração. São raras, bem sei as mulheres desta casta; mas existem...

Camilo terminou esta homenagem à dama dos seus pensamentos abrindo as asas a um suspiro que, se não chegou ao seu destino, não foi por culpa do autor. O companheiro não compreendeu a intenção do discurso, e insistiu em dizer que a formosa goiana estava longe de gostar de ninguém, e ele ainda mais longe de lho consentir.

O assunto agradava aos dois comprovincianos; falaram dele longamente até o aproximar da tarde. Pouco depois chegaram a um - pouso,- onde deviam pernoitar. 
Tirada a carga aos animais, cuidaram os criados primeiramente do café, e depois do jantar. Nessas ocasiões ainda mais pungiam ao nosso herói as saudades de Paris. Que diferença entre os seus jantares dos restaurants dos boulevards e aquela refeição ligeira e tosca, num miserável - pouso de estrada,- sem os acepipes da cozinha francesa, sem a leitura do Figaro ou da Gazette des Tribunaux!

Camilo suspirava consigo mesmo; tornava-se então ainda menos comunicativo. Não se perdia nada, porque o seu companheiro falava por dois.

Acabada a refeição, acendeu Camilo um charuto e Soares um cigarro de palha. Era já noite. A fogueira do jantar alumiava um pequeno espaço em roda; mas nem era precisa, porque a lua, começava a surgir de trás de um morro, pálida e luminosa, brincando nas folhas do arvoredo e nas águas tranquilas do rio que serpeava ali ao pé.

Um tropeiro dos tropeiros sacou a viola e começou a gargantear uma cantiga, que a qualquer outro encantaria pela rude singeleza dos versos e da toada, mas que ao filho do comendador apenas fez lembrar com tristeza as volatas $^{2}$ da Ópera. Lembrou-lhe mais; lembrou-lhe uma noite em que a bela moscovita, molemente sentada num camarote dos Italianos, deixava de ouvir as ternuras do tenor, para contemplá-lo de longe cheirando um raminho de violetas.

Soares atirou-se à rede e adormeceu.

O tropeiro cessou de cantar, e dentro de pouco tempo tudo era silêncio no pouso.

Camilo ficou sozinho diante da noite, que estava realmente formosa e solene. Não faltava ao jovem goiano a inteligência do belo; e a quase novidade daquele espetáculo, que uma longa ausência lhe fizera esquecer, não deixava de o impressionar imensamente.

De quando em quando chegavam aos seus ouvidos urros longínquos, de alguma fera que vagueava na solidão. Outras vezes eram aves noturnas, que soltavam ao perto os seus pios tristonhos. Os grilos, e também as rãs e os sapos formavam o coro daquela ópera do sertão, que o nosso herói admirava decerto, mas à qual preferia indubitavelmente a ópera cômica.

Assim esteve longo tempo, cerca de duas horas, deixando vagar o seu espírito ao sabor das saudades, e levantando e desfazendo mil castelos no ar. De repente foi chamado a si pela voz do Soares, que parecia vítima de um pesadelo. Afiou o ouvido e escutou estas palavras soltas e abafadas que o seu companheiro murmurava:

— Isabel... querida Isabel... Que é isso?... Ah! meu Deus! Acudam!

\footnotetext{
${ }^{2} J F$ rolatas
} 
As últimas sílabas eram já mais aflitas que as primeiras. Camilo correu ao companheiro e fortemente o sacudiu. Soares acordou espantado, sentouse, olhou em roda de si e murmurou:

- Que é?

- Um pesadelo.

— Sim, foi um pesadelo. Ainda bem! Que horas são?

- Ainda é noite.

— Já está levantado?

- Agora é que me vou deitar. Durmamos que é tempo.

- Amanhã lhe contarei o sonho.

No dia seguinte efetivamente, logo depois das primeiras vinte braças de marcha, referiu Soares o terrível sonho da véspera.

- Estava eu ao pé de um rio, disse ele, com a espingarda na mão, espiando as capivaras. Olho casualmente para a ribanceira que ficava muito acima, do lado oposto, e vejo uma moça montada num cavalo preto, vestida de preto, e com os cabelos, que também eram pretos, caídos sobre os ombros...

- Era tudo uma escuridão, interrompeu Camilo.

- Espere; admirei-me de ver ali, e por aquele modo, uma moça que me parecia franzina e delicada. Quem pensava o senhor que era?

- A Isabel.

- A Isabel. Corri pela margem adiante, trepei acima de uma pedra fronteira ao lugar onde ela estava, e perguntei-lhe o que fazia ali. Ela esteve algum tempo calada. Depois, apontando para o fundo do grotão, disse:

“- O meu chapéu caiu lá embaixo.

"-Ah!

"- O senhor ama-me? disse ela passados alguns minutos.

"- Mais que a vida!

"- Fará o que eu lhe pedir?

"- Tudo.

"- Bem, vá buscar o meu chapéu.

"- Olhei para baixo. Era um imenso grotão em cujo fundo fervia e roncava uma água barrenta e grossa. O chapéu, em vez de ir com a corrente por ali abaixo até perder-se de todo, ficara espetado na ponta de uma rocha, e lá do fundo parecia convidar-me a descer. Mas era impossível. Olhei para todos os lados, a ver se achava algum recurso. Nenhum havia...

- Veja o que é imaginação escaldada! abreviou observou Camilo.

- Já eu procurava algumas palavras com que dissuadisse Isabel da sua terrível ideia, quando senti pousar-me uma mão no ombro. Voltei-me; era um homem, era o senhor.

$-\mathrm{Eu}$ ? 
-É verdade. O senhor olhou para mim com um ar de desprezo, sorriu para ela ${ }^{3}$ e depois olhou para o abismo. Repentinamente, sem que eu possa dizer como, estava o senhor embaixo e estendia a mão para tirar o chapelinho fatal.

- Ah!

- A água porém, engrossando ${ }^{4}$ subitamente, ameaçava submergi-lo. Então Isabel, soltando um grito de angústia, esporeou o cavalo e atirou-se pela ribanceira abaixo. Gritei... chamei por socorro; tudo foi inútil. Já a água os enrolara enrolava em suas dobras... quando fui acordado pelo senhor.

Leandro Soares concluiu esta narração do seu pesadelo parecendo ainda assustado do que lhe acontecera... imaginariamente. Convém dizer que ele acreditava nos sonhos.

- Veja o que é uma digestão mal feita! observou exclamou Camilo quando o comprovinciano terminou a narração. Que série porção de tolices! O chapéu, a ribanceira, o grotão cavalo, e mais que tudo a minha presença nesse melodrama fantástico, tudo isso é obra de quem digeriu mal o jantar. Em Paris há teatros que representam pesadelos assim, - piores do que o seu porque são mais compridos. Mas o que eu vejo também é que essa moça não o deixa nem dormindo.

- Nem dormindo!

Soares disse estas duas palavras quase como um eco, sem consciência. Desde que concluíra a narração, e logo depois das primeiras palavras de Camilo, entrara a fazer consigo uma série de reflexões que não chegaram ao conhecimento do autor desta narrativa. O mais que lhes posso dizer é que não eram alegres, porque a fronte lhe descaiu, enrugou-se-lhe a testa, $\mathrm{e}$ ele, cravando os olhos nas orelhas do animal, recolheu-se a um inviolável silêncio.

A viagem, daquele dia em diante, foi menos suportável para Camilo de que até ali. Além de uma leve melancolia que se apoderara do companheiro, ia-se-lhe tornando enfadonho aquele andar léguas e léguas que pareciam não acabar mais. § Afinal voltou Soares à sua habitual verbosidade, mas já então nada podia vencer o tédio mortal que se apoderara do mísero Camilo.

Quando porém avistou a cidade, perto da qual estava a fazenda, onde vivera as primeiras auroras da sua mocidade, Camilo sentiu abalar-se-lhe fortemente o coração. Um sentimento sério o dominava. Por algum tempo, ao menos, Paris com os seus esplendores cedia o lugar à pequena e honesta pátria dos Seabras.

\footnotetext{
${ }^{3} J F$ ele

${ }^{4} J F$ ou grossando
} 
III

\section{O encontro}

Foi um verdadeiro dia de festa aquele em que o comendador cingiu ao peito o filho que oito anos mandara a terras estranhas. Não pôde reter as lágrimas o bom velho, - não pôde, que elas vinham de um coração ainda viçoso de afetos e exuberante de ternura. §Não menos intensa e sincera foi a alegria de Camilo. Beijou repetidamente as mãos e a fronte do velho pai, abraçou os parentes, os amigos de outro tempo, os conhecidos de oito anos, $\mathrm{e}$ durante alguns dias, - não muitos, - parecia completamente curado dos seus desejos de regressar à Europa.

$\mathrm{Na}$ cidade e seus arredores não se falava em outra coisa. O assunto, não principal, mas exclusivo das palestras e comentários era o filho do comendador. Ninguém se fartava de o elogiar. Admiravam todos as suas AdmiravamIhe as maneiras e a sua elegância. A mesma superioridade com que ele falava a todos achava entusiastas sinceros. $\S$ Durante muitos dias foi totalmente impossível que o bom rapaz pensasse em outra coisa que não fosse contar as suas viagens aos seus amáveis conterrâneos. Mas pagavam-lhe a maçada, porque a menor coisa que ele dissesse tinha aos olhos dos outros uma graça indefinível. § Ninguém hesitava em elogiá-lo cara a cara. Os que o não faziam assim iam direto ao pai, que tho vinha repetir depois cheio de orgulho. §O padre Maciel, que o batizara vinte e sete anos antes, e que o via já homem completo, era o primeiro pregoeiro da sua transformação.

- Pode gabar-se, Sr. comendador, dizia ele ao pai de Camilo, pode gabar-se de que o céu lhe deu um rapaz de truz! Santa Luzia vai ter um médico de primeira ordem, se me não engana o afeto que tenho a esse que era ainda ontem um pirralho. E não só médico, mas até bom filósofo; é verdade, parece-me bom filósofo. Sondei-o ontem nesse particular, e não lhe achei ponto fraco ou duvidoso.

O tio Jorge andava a perguntar a todos o que pensavam do sobrinho Camilo. O tenente coronel Veiga agradecia à Providência a chegada do Dr. Camilo nas proximidades do Espírito Santo.

- Sem ele, o meu baile seria incompleto.

O Dr. Matos não foi o último que visitou o filho do comendador. Era um velho alto e bem feito, ainda que um tanto quebrado pelos anos. Tinha política oposta à do comendador; o que não impedia que fossem íntimos amigos, e o tinham provado um ao outro em mais de uma ocasião

- Venha, doutor, disse o velho Seabra apenas o viu assomar à porta; venha ver o meu homem. 
- Homem, com efeito, respondeu Matos contemplando o rapaz. Está mais homem do que eu supunha. Também já lá vão oito anos! Venha de lá esse abraço!

O moço abriu os braços ao velho. Depois, como era costume fazer a quantos o iam ver, contou-lhe alguma coisa das suas viagens e estudos. É perfeitamente inútil dizer que o nosso herói omitiu sempre tudo quanto pudesse abalar o bom conceito em que estava no ânimo de todos. A dar-lhe crédito, vivera, quase como um anacoreta; e ninguém ousava pensar o contrário.

Tudo eram pois alegrias na boa cidade e seus arredores; e o jovem médico, lisonjeado com a inesperada recepção que teve, continuou a não pensar muito em Paris. \& Mas o tempo corre, e as nossas sensações com ele se modificam. No fim de quinze dias tinha Camilo esgotado a novidade das suas impressões; a fazenda começou a mudar de aspecto; os campos ficaram monótonos, as árvores monótonas, os rios monótonos, a cidade monótona, ele próprio monótono. Invadiu-o então uma coisa a que podemos chamar a - nostalgia do exílio.

- Não, dizia ele consigo, não posso ficar aqui mais dois três meses. Paris ou o cemitério, tal é o dilema que se me oferece. Daqui a dois três meses, estarei morto ou na em caminho da Europa.

O aborrecimento de Camilo não escapou aos olhos do pai, que quase vivia a olhar para ele.

- Tem razão, pensava o comendador. Quem lá viveu por essas terras que dizem ser tão bonitas e animadas, não pode estar aqui muito alegre. É preciso dar-lhe alguma ocupação... a política, por exemplo.

- Política! exclamou Camilo, quando, o pai lhe falou nesse assunto. De que me serve a política, meu pai?

- De muito. Dá lugar às posiçōes. Serás primeiro deputado provincial; podes ir depois para a Câmara no Rio de Janeiro. Um dia interpelas o ministério, e se ele cair, podes subir ao governo. Nunca tiveste ambição de ser ministro?

- Nunca.

-É pena!

- Por quê?

- Porque é bom ser ministro.

- Governar os homens, não é? disse Camilo rindo; é um sexo ingovernável; prefiro o outro.

Seabra riu-se do repente, mas não perdeu a esperança de convencer o herdeiro.

Havia já vinte dias que o médico estava em casa do pai, quando se lembrou da história que lhe contara Soares e do sonho que este tivera no 
pouso. $\S$ A primeira vez que foi à cidade e esteve com o filho do negociante, perguntou-lhe:

- Diga-me, como vai a sua Isabel, que ainda a não vi?

Soares olhou para ele com o sobrolho carregado e levantou os ombros resmungando um seco:

- Não sei.

Camilo não insistiu.

-A moléstia ainda está no período agudo, disse ele consigo.

Não tornou a falar-lhe do assunto.

Teve porém curiosidade de ver a formosa Isabelinha, que tão por terra deitara aquele verboso cabo eleitoral. A todas as moças da localidade, em dez léguas em redor, havia já falado o jovem médico. Isabel era a única esquiva até então. Esquiva não digo bem. Camilo fora uma vez à fazenda do Dr. Matos; mas a filha estava doente. Pelo menos foi isso o que lhe disseram.

- Descanse, dizia-lhe um vizinho a quem ele mostrara impaciência de conhecer a amada de Leandro Soares; há de vê-la no baile do coronel Veiga, ou na festa do Espírito Santo, ou em outra qualquer ocasião.

A beleza da moça, que ele não julgava pudesse ser superior nem sequer igual à da viúva do príncipe Alexis, a paixão incurável de Soares, e o tal ou qual mistério com que falava de Isabel, tudo isso excitou ao último ponto a curiosidade do filho do comendador.

No domingo próximo, oito dias antes do Espírito Santo, saiu Camilo da fazenda para ir à missa na igreja da cidade, como já fizera nos domingos anteriores. $\S \mathrm{O}$ cavalo ia a passo lento, a compasso com o pensamento do cavaleiro, que se espreguiçava pelo campo fora em busca de sensações que já não tinha nem esperava ter mais e que ansiava ter de novo.

Mil singulares ideias atravessavam o cérebro de Camilo. Ora, almejava alar-se com cavalo e tudo, rasgar os ares e ir cair defronte do Palais-Royal, ou em outro qualquer ponto da capital do mundo. Logo depois fazia a si mesmo a descrição de um cataclismo ${ }^{5}$ tal, que ele viesse a achar-se almoçando no café Tortoni, dois minutos depois de chegar ao altar o Padre Maciel.

Ninguém pode saber até onde chega uma imaginação vadia e ardente. A de Camilo criou então muitos prodígios semelhantes, com o que se lhe abreviava o caminho.

De repente, ao quebrar uma volta da estrada, descobriu ao longe duas senhoras a cavalo acompanhadas por um pajem. Picou as de esporas e dentro de pouco tempo estava junto dos três cavaleiros. §Uma das senhoras voltou a cabeça, sorriu e parou. Camilo aproximou-se, com a cabeça descoberta, e

${ }^{5} \mathrm{HMN}$ cataclisma 
estendeu-lhe a mão, que ela apertou.

A senhora a quem cumprimentara era a esposa do tenente-coronel Veiga. Representava ter quarenta e cinco anos, mas estava assaz conservada. $\S$ A outra senhora, ao ver sentindo o movimento da companheira, fez parar também o cavalo, e voltou igualmente a cabeça. § Camilo não olhava então para ela. Estava ocupado em ouvir a D. Gertrudes, que lhe dava notícias do tenente-coronel.

- Agora só pensa na festa, dizia ela; já deve estar na igreja. Vai à missa, não?

- Vou.

- Vamos juntos.

Trocadas estas palavras, que foram rápidas, Camilo procurou com os olhos a outra cavaleira. Ela porém ia já alguns passos adiante. O médico colocou-se ao lado de D. Gertrudes, e a comitiva continuou a andar. §Iam assim conversando havia já uns dez minutos, quando o cavalo da senhora que ia adiante estacou.

— Que é, Isabel? perguntou D. Gertrudes.

- Isabel! exclamou Camilo, sem dar atenção ao incidente que provocara a pergunta da esposa do coronel.

A moça voltou a cabeça e levantou os ombros respondendo secamente:

- Não sei.

A causa era um rumor que o cavalo sentira por trás de uma espessa moita de taquaras que ficava à esquerda do caminho. $\S$ Antes porém que o pajem ou Camilo fosse examinar a causa da relutância do animal, a moça fez um esforço supremo, e chicoteando vigorosamente o cavalo, conseguiu que este vencesse o terror, e deitasse a correr a galope adiante dos companheiros. Matos?

— Isabel! disse Camilo a D. Gertrudes. Aquela moça será a filha do Dr.

- É verdade. Não a conhecia?

— Há oito anos que a não vejo. Está uma flor! Já me não admira que se fale aqui tanto na sua beleza. Disseram-me que estava doente...

- Esteve; mas as suas doenças são coisas de pequena monta. São nervos; assim se diz, creio eu, quando se não sabe do que uma pessoa sofre padece...

Isabel parara ao longe, e voltada para a esquerda da estrada, parecia admirar o espetáculo da natureza. Daí a alguns minutos estavam perto dela os seus companheiros. A moça ia prosseguir a marcha, quando D. Gertrudes lhe disse:

- Isabel!

- A moça voltou o rosto. D. Gertrudes aproximou-se dela. 
"A parasita azul"

- Não te lembras do Dr. Camilo Seabra?

- Talvez não se lembre, disse Camilo. Tinha doze anos quando eu saí daqui, e já lá vão oito!

- Lembro-me, respondeu Isabel curvando levemente a cabeça, mas sem olhar para o médico.

E chicoteando de mansinho o cavalo, seguiu para diante. § Por mais singular que fosse aquela maneira de reatar um conhecimento antigo, $o$ que mais impressionou então o filho do comendador foi a beleza de Isabel, que lhe pareceu estar na altura da reputação.

Tanto quanto se podia julgar à primeira vista, a esbelta cavaleira devia ser mais alta que baixa. Era morena, - mas de um moreno acetinado e macio, com uns longes de delicadíssimos longes cor-de-rosa por baixo da epiderme, - o que seria efeito da agitação, visto que afirmavam ser extremamente pálida. Os olhos, - não lhes pôde Camilo ver a cor, mas sentiu-lhes a luz, que valia mais talvez, apesar de o não terem fitado, e compreendeu logo que com olhos tais a formosa goiana houvesse fascinado o mísero Soares.

Não averiguou, - nem pôde, as restantes feições da moça; mas o que pôde contemplar à vontade, o que já vinha admirando de longe, era a elegância nativa do busto e o gracioso desgarro com que ela montava. § Vira muitas amazonas elegantes e destras. Aquela porém tinha alguma coisa em que se avantajava às outras; era talvez o desalinho do gesto, talvez a espontaneidade dos movimentos, outra coisa talvez, ou todas essas juntas, que davam à interessante goiana incontestável supremacia.

Isabel parava de quando em quando o cavalo e dirigia a palavra à esposa do coronel, a respeito de qualquer acidente, - de um efeito de luz, de um pássaro que passava, de um som que se ouvia, - mas em nenhuma ocasião encarava ou sequer olhava de esguelha o filho do comendador. $\S$ Absorvido na contemplação da moça, Camilo deixou cair a conversa, e havia já alguns minutos que ele e D. Gertrudes iam cavalgando, sem dizer palavra, ao lado um do outro. \& Foram interrompidos em sua marcha silenciosa por um cavaleiro, que vinha atrás da comitiva a trote largo.

Era Soares.

O filho do negociante vinha bem diferente do que até ali andava. Cumprimentou-os sorrindo e jovial como estivera nos primeiros dias de viagem com o do médico. Não era porém difícil conhecer que a alegria de Soares era um artifício. O pobre namorado fechava o rosto de quando em quando, ou fazia um gesto de desespero que felizmente escapava aos outros. § Nada há porém que possa escapar a um autor que timbra em trazer instruídos os seus leitores. Eu podia apresentar-lhes o rapaz meio triste, meio alegre, sem dizer a razão clara deste alegro-melancolia. Não, senhor; prefiro dizer-lhes que o pretendente de Isabel fingia uma alegria que não tinha, para melhor esconder a cólera que o devorava. 
"A parasita azul"

Cólera, por quê? Amava apaixonadamente a moça, e o seu amor era tão complacente e modesto, que se contentava com a ver de longe; perdoava-lhe até a indiferença com a condição de que ela não havia de amar a outro.

Ora, o ciúme já mordia tenazmente o coração do pobre namorado, ciúme sem causa positiva, ciúme de instinto e pressentimento.

Soares Ele receava o triunfo de um homem que, material física e intelectualmente lhe era superior; que, além disso, gozava naquela ocasião a grande vantagem de dominar a atenção pública, que era o urso da aldeia, o acontecimento do dia, o homem da situação. Tudo conspirava para derrubar a última esperança de Soares, que era a esperança de ver morrer a moça isenta de todo o vínculo conjugal. O infeliz namorado tinha o sestro, aliás comum, de querer ver quebrada ou inútil, a taça que ele não podia levar aos lábios.

Cresceu porém seu receio quando, estando escondido no taquaral de que falei acima, para ver passar Isabel, como costumava fazer muitas vezes, descobriu a pessoa de Camilo na comitiva. Não pôde reter uma exclamação de surpresa, e chegou a dar um passo na direção da estrada. Deteve-se a tempo. §Os cavaleiros, como vimos, passaram adiante, deixando o cioso pretendente jurando aos céus e à terra que tomaria desforra do seu atrevido rival, se o fosse.

Não era rival, bem sabemos; o coração de Camilo guardava ainda fresca a memória da Artemisa moscovita, cujas lágrimas, apesar da distância, o rapaz sentia que eram ardentes e aflitivas. Mas quem poderia convencer a Leandro ${ }^{6}$ Soares que o elegante moço da Europa, como o lhe chamavam, não ficaria enamorado da esquiva goiana?

Isabel, entretanto, apenas vira o infeliz pretendente, deteve o cavalo e estendeu-lhe afetuosamente a mão. Um adorável sorriso acompanhou este movimento. Não era bastante para dissipar as dúvidas do pobre moço. Diversa foi porém a impressão de Camilo:

- Ama-o, ou é uma grande velhaca, pensou ele.

Casualmente, - e pela primeira vez, — olhava Isabel para o filho do comendador. Perspicácia ou adivinhação, leu-lhe no rosto esse pensamento oculto; franziu levemente a testa com uma expressão tão viva de estranheza, que o médico ficou perplexo e não pôde deixar de acrescentar, já então com os lábios, à meia voz, falando para si:

- Ou fala com o diabo.

- Talvez, murmurou a moça com os olhos fitos no chão.

Isto foi dito assim, sem que os outros dois percebessem, e sem que ele nem ela se dirigissem um ao outro. Camilo não podia desviar os olhos da formosa Isabel,

${ }^{6} J F$ Leandres 
meio espantado, meio curioso, depois da palavra murmurada por ela em tão singulares condições. Soares olhava para Camilo com a mesma ternura com que um gavião espreita uma pomba. Isabel brincava com o chicotinho. D. Gertrudes, que temia perder a missa do padre Maciel e receber um reparo amigável do marido, deu voz de marcha, e a comitiva seguiu imediatamente.

\begin{abstract}
A festa
No sábado seguinte a cidade revestira um desusado ${ }^{7}$ aspecto. De todos os arraiais vizinhos toda a parte correra uma chusma de povo que ia assistir à festa anual do Espírito Santo.

Vão rareando os lugares em que de todo se não apagou o gosto dessas festas clássicas, resto de outras eras, que os escritores do século futuro hão de estudar com sofreguidão curiosidade, para pintar aos seus contemporâneos um Brasil que eles já não hão de conhecer.

Não há muitos anos presenciava esta corte uma popularíssima festa do Espírito Santo na antiga igreja de Santa Ana. Havia ao lado um palanque onde o imperador do divino, que era uma criança, e o seu guardaestoque, que também o era, passavam ali a tarde e a noite nos dias em que durava a festividade.

O palanque chamava-se império.

Uma banda de música tocava ali harmoniosas peças que o povo ouvia de graça, porque era no tempo em que havia espetáculos gratuitos.

De noite queimava-se um fogo artificial. O fogueteiro não escapava, ou raras vezes escapava a uma crítica severa da parte mais jovial da assembleia. As famílias, umas em cadeiras, outras em esteiras, conforme as respectivas posses, passavam a noite no velho campo de Santa Ana.

Às vezes um incidente mais grave perturbava um ou outro ponto da localidade, e o solo histórico do Campo recebia alguns respingos de sangue do nariz e até da cabeça de algum circunstante menos prudente; mas a polícia punha termo ao fato convidando os interruptores a irem refletir, em lugar menos amplo, acerca da vantagem de não perturbar o sossego público.

Figurava nestas festas históricas o imortal Teles, - imortal na memória da geração presente, - dando espetáculos muito variados na sua clássica barraca. O povo concorria em massa; os estudantes faziam as suas travessuras; tratavam-se namoros, iniciavam-se casamentos... Acabou, acabou tudo isso. O Rio de Janeiro civilizou-se e aprendeu novas maneiras de se divertir.

A tradição da maneira antiga vai-se já apagando nos costumes brasileiros. § No tempo em que esta história se passa uma das mais genuínas festas do Espírito Santo era a da cidade de Santa Luzia.

O tenente-coronel Veiga, que era então o imperador do divino, estava em uma casa que possuía na cidade.
\end{abstract}

\footnotetext{
${ }^{7} J F$ desudado
} 
Na noite de sábado foi ali ter o bando dos pastores, composto de homens e mulheres, com o seu pitoresco vestuário, e acompanhado pelo clássico velho, que era um sujeito de calção e meia, sapato raso, casaca esguia, colete comprido e grande bengala na mão.

Camilo estava em casa do coronel, quando ali apareceu o bando dos pastores, com alguns músicos à frente, e muita gente atrás. Formavam Formaram logo, ali mesmo na rua, um círculo, e um pastor acompanhado de uma pastora , ; um pastor e uma pastora iniciaram a dança clássica. Dançaram, cantaram e tocaram todos, à porta e na sala do coronel, que estava literalmente a lamber-se de gosto. É ponto duvidoso, e provavelmente nunca será liquidado, se o tenente-coronel Veiga preferia naquela ocasião ser ministro de Estado a ser imperador do Espírito Santo.

E todavia aquilo era apenas uma amostra da imperial grandeza do tenentecoronel. O sol do domingo devia alumiar maiores coisas. Parece que esta razão determinou o rei da luz a trazer nesse dia os seus melhores raios. O céu nunca se mostrara mais limpidamente azul. Algumas nuvens grossas, durante a noite, chegaram a emurchecer as esperanças dos festeiros; felizmente, sobre a madrugada soprara um vento rijo que varreu o céu e purificou a atmosfera.

A população correspondeu à solicitude da natureza. Logo cedo apareceu ela com os seus vestidos domingueiros, - jovial, risonha, palreira, nada menos que feliz.

$\mathrm{O}$ ar atroava com foguetes; os sinos convidavam alegremente o povo à cerimônia religiosa.

Camilo passara a noite na cidade em casa do padre Maciel, e foi acordado, mais cedo do que imaginara supusera, com os repiques e foguetada e mais demonstrações da cidade alegre. Em casa do pai continuara o moço os seus hábitos de Paris, em que o comendador julgou não dever perturbá-lo. Acordava portanto às 10 ou 11 horas da manhã, exceto os domingos, em que ia à missa, para de todo em todo não ofender os hábitos da terra.

- Que diabo é isto, padre? gritou Camilo do quarto onde estava, e no momento em que uma girândola lhe abria definitivamente os olhos.

- Que há de ser? respondeu o padre Maciel, metendo a cabeça pela porta: é a festa.

- Então a festa começa de noite?

- De noite! exclamou o padre. É dia claro.

Camilo não pôde conciliar o sono, e viu-se obrigado a levantar-se. Almoçou com o padre, contou duas anedotas, confessou ao hóspede que Paris era o ideal das cidades, e saiu para ir ter à casa do imperador do divino. $\mathrm{O}$ padre saiu com ele. Em caminho viram de longe o Leandro Soares. 
- Não me dirá, padre, perguntou Camilo, por que razão a filha do Dr. Matos não atende àquele pobre rapaz que gosta tanto dela?

Maciel consertou os óculos e expôs a seguinte reflexão:

- Você parece-me parece tolo.

- Não tanto, como lhe pareço, replicou o filho do comendador, porque mais de uma pessoa tem feito a mesma pergunta.

- Assim é, na verdade, disse o padre; mas há coisas que outros dizem e a gente não repete. A Isabelinha não gosta do Soares simplesmente porque não gosta.

- Não lhe parece que essa moça é um tanto esquisita?

- Não, disse o padre; , parece-me uma grande finória.

- Ah! por quê?

- Suspeito que tem muita ambição; e não aceita o amor do Soares, a ver se pilha algum casamento que lhe abra a porta das grandezas políticas.

- Ora, disse Camilo levantando os ombros.

- Não acredita?

- Não.

- Pode ser que eu me engane; mas eu creio que é isto mesmo. Aqui cada qual dá uma explicação à isenção de Isabel; todas as explicações porém me parecem absurdas; a minha creio que é a melhor.

Nisto mostrava bem o padre Maciel pertencer à nossa família humana; a sua conjectura era melhor e mais verdadeira que as outras, unicamente pela razão de ser sua.

Camilo fez algumas objeções à explicação do padre, e despediu-se dele para ir à casa do tenente-coronel.

O festivo imperador estava literalmente fora de si. Era a primeira vez que exercia aquele cargo honorífico e timbrava em fazê-lo brilhantemente, e até melhor que os seus predecessores. Ao natural desejo de não ficar por baixo, acrescia o elemento da inveja política. Alguns adversários seus diziam pela boca pequena que o brioso coronel não era capaz de dar conta da mão.

- Pois verão se sou capaz, foi a resposta que ele deu quando alguns solícitos amigos the foram contar foi o que ele disse ao ouvir de alguns amigos a malícia dos adversários.

Quando Camilo entrou na sala, acabava o tenente-coronel de dar explicar algumas ordens relativas ao jantar que se devia seguir à festa, e ouvia algumas informações que lhe dava um irmão definidor acerca de uma cerimônia da sacristia.

- Não ouso falar-lhe, coronel, disse o filho do comendador, quando o Veiga ficou só com ele; não ouso interrompê-lo.

- Não interrompe, acudiu o imperador do divino; agora deve tudo estar acabado. O comendador vem?

- Já cá deve estar. 
— Já viu a igreja?

- Ainda não.

— Está muito bonita. Não é por me gabar; creio que a festa não desmerecerá das outras, e até em algumas coisas há de ir melhor.

Era absolutamente impossível não concordar com esta opinião, quando aquele que a exprimia fazia assim o seu próprio louvor. Camilo encareceu ainda mais o mérito da festa. O coronel ouvia-o com um riso de satisfação íntima; , e dispunha-se a provar que o seu jovem amigo ainda não apreciava bem a situação, quando este desviou a conversa, perguntando:

— Ainda não veio o Dr. Matos?

- Já.

- Com a família, jả se vê?

- Sim, com a família.

- Neste momento foram interrompidos pelo som de muitos foguetes e de uma música que se aproximava.

— São eles! disse Veiga; vêm buscar-me. Há de dar-me licença.

O coronel estava até então de calça preta e rodaque de brim. Correu a preparar-se com o traje e as insígnias do seu elevado cargo. Camilo chegou à janela para ver o cortejo. § Não tardou que aparecesse o cortejo, este aparecesse composto de uma banda de música, da irmandade do Espírito Santo e dos pastores da véspera. Os irmãos vestiam as suas opas encarnadas, e vinham a passo grave, cercados do povo, que enchia a rua e se aglomerava à porta do tenente-coronel para vê-lo sair.

Quando o cortejo parou em frente da casa do tenente-coronel cessou a música de tocar e todos os olhos se voltaram curiosamente para as janelas para ver se o viam. Mas o imperador estreante estava ainda por completar a sua edição, e os curiosos tiveram de contentar-se com a pessoa do Dr. Camilo.§ Entretanto quatro ou seis irmãos mais graduados destacaram-se do grupo e subiram as escadas do tenente-coronel.

Minutos depois cumprimentava Camilo os ditos irmãos graduados, um dos quais, mais graduado que os outros, não o era só no cargo, mas também, e sobretudo, no tamanho. E a estatura do major Brás seria a coisa mais notável da sua pessoa, se lhe não pedisse meça meças a magreza do próprio major. A opa do major também era notável no gênero, apesar disto, ficava-lhe bem, porque nem ia até abaixo da curva da perna como a dos outros, nem lhe ficava na cintura, como devera ser, no caso de ter sido feita pela mesma medida. Era uma opa termo-médio. Ficava-lhe entre a cintura e a curva, e foi feita assim de propósito para conciliar os princípios da elegância com a estatura do major.

Todos os irmãos graduados estenderam a mão ao filho do comendador e perguntaram ansiosamente pelo tenente-coronel. 
"A parasita azul"

- Não tarda; foi vestir-se, respondeu Camilo. ele.

- A igreja está cheia, disse um dos irmãos graduados; só se espera por

- É justo esperar por ele, opinou o major Brás.

- Apoiado, disse o coro dos irmãos.

- Demais, continuou o imenso oficial, temos tempo; e não vamos para longe.

Os outros irmãos apoiaram com o gesto esta opinião do major, que, ato contínuo, começou a contar dizer a Camilo os mil trabalhos que a festa lhes dera, a ele e aos cavalheiros que o acompanhavam naquela ocasião, não menos que ao tenente-coronel.

- Como recompensa dos nossos débeis esforços (Camilo fez um sinal negativo a estas palavras do major Brás), temos a consciência de que a coisa não sairá de todo mal.

Ainda estas palavras não tinham bem saído dos lábios do digno oficial, quando assomou à porta da sala o tenente-coronel em todo o esplendor da sua transformação.

Camilo perdera de todo as noções que tinha a respeito do traje e insígnias de um imperador do Espírito Santo. Não foi pois sem grande pasmo que viu assomar à porta da igreja sala a figura do tenente-coronel.

Além da calça preta, que já tinha no corpo quando ali chegou Camilo, o tenente-coronel envergara uma casaca, que pela regularidade e elegância do corte podia rivalizar com as dos mais apurados membros do Cassino Fluminense. Até aí tudo ia bem. Ao peito rutilava uma vasta comenda da ordem da Rosa, que lhe não ficava mal. Mas o que excedeu a toda a expectação, o que the pintou no rosto do nosso Camilo a mais completa expressão de assombro, foi uma brilhante e vistosa coroa de papelão forrado de papel dourado, que o tenente-coronel trazia na cabeça.

Camilo recuou um passo e cravou os olhos na insígnia imperial do tenente-coronel. Já lhe não lembrava aquele acessório indispensável em ocasiões daquelas semelhantes, e tendo vivido oito anos no meio de uma civilização diversa, não imaginava que ainda existissem costumes que ele julgava enterrados.

O imperador tenente-coronel apertou a mão a todos os amigos e declarou que estava pronto a acompanhá-los.

- Não façamos esperar o povo, disse ele.

Imediatamente, desceram à rua. § Houve no povo um movimento de curiosidade, quando viu aparecer à porta a opa encarnada de um dos irmãos que haviam subido. Logo atrás apareceu outra opa, e não tardou que as restantes opas aparecessem também flanqueando o vistoso imperador. § A coroa dourada, apenas o sol lhe bateu de chapa, entrou a despedir faíscas 
quase inverossímeis. §o imperador $\mathrm{O}$ tenente-coronel olhou a um lado e outro, fez algumas inclinações leves de cabeça a uma ou outra pessoa da multidão, e foi ocupar o seu lugar de honra no cortejo. § A música rompeu logo uma marcha, que foi executada pelo imperador tenente-coronel, a irmandade e os pastores, na direção da igreja.

Apenas da igreja avistaram o cortejo, o sineiro que já estava à espreita, pôs em obra as lições mais complicadas do seu ofício, enquanto uma girândola, entremeada de alguns foguetes soltos, anunciava às nuvens do céu que o imperador do divino era chegado. $\$ \mathrm{Na}$ igreja houve um rebuliço geral apenas se anunciou que era chegado o imperador. Um mestre-decerimônias ativo e desempenado ia abrindo alas, com grande dificuldade, porque o povo, ansioso por ver a figura do tenente-coronel aglomerava-se desordenadamente e desfazia toda a obra do mestre-de-cerimônias. Afinal aconteceu o que sempre acontece nessas ocasiões; as alas foram-se abrindo por si mesmas, e ainda que com alguma dificuldade, o imperador algum custo, o tenente-coronel atravessou a multidão, precedido e acompanhado pela irmandade, até chegar ao trono que se levantava ao lado do altar-mor. § Subiu com firmeza os degraus do trono, e sentou-se nele, tão orgulhoso como se governasse dali todos os impérios juntos do mundo.

Quando Camilo chegou à igreja, já a festa havia começado. Achou um lugar sofrível, ou antes inteiramente bom, porque dali podia dominar um grande grupo de senhoras, entre as quais descobriu a formosa Isabel.

Camilo estava ansioso por falar outra vez a Isabel. O encontro na estrada e a singular perspicácia de que a moça dera prova nessa ocasião, não lhe haviam saído da cabeça. §A moça pareceu não dar por ele; : mas Camilo era tão versado em tratar com o belo sexo, que não lhe foi difícil perceber que ela o tinha visto e intencionalmente não voltava os olhos para o lado dele. § Esta circunstância, ligada aos incidentes do domingo anterior, fez-lhe nascer no espírito a seguinte pergunta:

— Mas que tem ela contra mim?

Cantado o evangelho, subiu ao púlpito o padre Maciel que, como de costume, pregava o sermão.

O padre Maciel tinha o talento de dar todos os anos um sermão novo sem acrescentar nem tirar nada do primeiro sermão que pregara. Bastava-lhe simplesmente alterar as orações e os períodos; metia às vezes um advérbio ou uma conjunção de mais; o restante era a mesma coisa e era também outra coisa.

De alguns anos em diante o sermão sofreu uma pequena reforma; entraram alguns períodos novos, que como os leitores se hão de lembrar, eram da carta de Camilo ao pai, por ocasião da morte do padrinho. Esquecido talvez desta circunstância, não alterou nessa parte o sermão, e já daqui pode o leitor imaginar a surpresa do filho do comendador quando ouviu caírem de público uma série de frases filosóficas, que ele reconheceu logo, por lhe haverem custado algumas horas de profunda meditação.

A festa prosseguiu sem novidade. Camilo não tirava os olhos de sua bela charada, nome que já lhe dava, mas a charada parecia refratária a todo 
o sentimento de curiosidade. § Uma vez porém, quase no fim, encontraramse os olhos de ambos. Pede a verdade que se diga que o rapaz surpreendeu a moça a olhar para ele. Cumprimentou-a; foi correspondido; nada mais. § Acabada a festa foi a irmandade levar o imperador tenente-coronel até a casa. No meio da lufa-lufa da saída, Camilo, que estava embebido a olhar para Isabel, ouviu uma voz desconhecida que lhe dizia ao ouvido:

- Veja o que faz!

Camilo voltou-se e deu com um homem baixinho e magro, de olhos miúdos e vivos, pobre mas asseadamente trajado. § Encararam-se alguns segundos sem dizer palavra. Camilo não conhecia aquela cara e não se atrevia a pedir a explicação das palavras que ouvira, conquanto ardesse por saber o resto.

— Há um mistério, continuou o desconhecido. Quer descobri-lo?

Houve algum tempo de silêncio. me dizer...

- O lugar não é próprio, disse Camilo; mas se tem alguma coisa que

- Não; descubra o senhor mesmo.

E dizendo isto desapareceu no meio do povo o homem baixinho e magro, de olhos vivos e miúdos. § Camilo acotovelou umas dez ou doze pessoas, pisou uns quinze ou vinte calos, pediu outras tantas vezes perdão da sua imprudência, até que se achou na rua sem ver nada que se parecesse com o desconhecido.

- Um romance! disse ele; estou em pleno romance.

Nisto saíam da igreja Isabel, D. Gertrudes, e o Dr. Batista Matos. Camilo aproximou-se do grupo e cumprimentou-os. Batista Matos deu o braço a D. Gertrudes; Camilo ofereceu timidamente o seu a Isabel.

A moça hesitou; mas não era possível recusar. Passou o braço no do jovem médico e o grupo dirigiu-se para a casa onde o tenente-coronel já estava e mais algumas pessoas importantes da localidade. $\S$ No meio do povo havia um homem que também se dirigia para a casa do coronel e que não tirava os olhos de Camilo e de Isabel. § Esse homem mordia o lábio até fazer sangue. Será preciso dizer que era Leandro Soares?

Paixão

A distância da igreja à casa era pequena; e a conversa entre Isabel e Camilo não foi longa nem seguida. E todavia, leitor, se alguma simpatia te merece a princesa moscovita, deves sinceramente lastimá-la. A aurora de um novo sentimento começava a dourar as cumeadas do coração de Camilo; 
ao subir as escadas, confessava o filho do comendador de si para si, que a interessante patrícia tinha qualidades superiores às da bela princesa russa. Hora e meia depois, isto é, quase no fim do jantar, o coração de Camilo confirmava plenamente esta descoberta do seu investigador espírito.

A conversa, entretanto, não passou de coisas totalmente indiferentes; mas Isabel falava com tanta distinção doçura e graça, posto não alterasse nunca a sua habitual reserva; os olhos eram tão bonitos de ver ao perto, e os cabelos também, e a boca igualmente, e as mãos do mesmo modo, que o nosso ardente mancebo, só mudando totalmente de natureza, poderia resistir ao influxo de tantas graças juntas.

O jantar correu sem novidade apreciável. Reuniram-se à mesa do tenente-coronel todas as notabilidades do lugar, o estado-maior, o vigário, $\mathrm{o}$ juiz municipal, o negociante, o fazendeiro, reinando sempre de uma ponta à outra da mesa a maior cordialidade e harmonia. $\S \mathrm{O}$ imperador do divino, já então restituído ao seu vestuário comum, fazia as honras da mesa com verdadeiro entusiasmo. A festa era o objeto da geral conversa, entremeada, é verdade, de reflexões políticas, em que todos estavam de acordo, porque eram do mesmo partido, homens e senhoras.

Foi ali assentado que os seus adversários ausentes eram os mais ineptos, corruptos e impopulares sujeitos que houve nunca desde o Amazonas até ao Prata. A aspereza desta opinião era compensada pela ideia de que os adversários, em iguais reuniões, já haviam dito a mesma coisa, e se propunham a repeti-la, tão depressa lhes fosse do Rio de Janeiro a notícia de que a opinião pública abandonara os atuais governantes.

O major Brás tinha por costume fazer um ou dois brindes longos e eloquentes em cada jantar de certa ordem a que assistisse. A facilidade com que ele se exprimia, não tinha rival nas tantas mil léguas quadradas de que se compõe a superfície da em toda a província. Além disso, como era dotado de descomunal estatura, dominava de tal modo o auditório, que o simples levantar-se era já meio triunfo.

Não podia o major Brás deixar passar incólume o jantar do tenentecoronel; ia-se entrar na sobremesa quando o eloquente major pediu licença para dizer algumas palavras singelas e toscas. Um murmúrio, equivalente aos não-apoiados das câmaras, acolheu esta declaração do orador, e o auditório preparou o ouvido para receber as pérolas que lhe iam cair da boca.

- "O ilustre auditório que me escuta, disse ele, desculpará a minha ousadia; não vos fala o talento, senhores; fala-vos o coração.

"Meu brinde é curto; para celebrar as virtudes e a capacidade do ilustre tenente-coronel Veiga não é preciso fazer um longo discurso. Seu nome diz tudo; a minha voz nada adiantaria..."

O auditório revelou por sinais que aplaudia sem restrições o primeiro membro desta última frase, e com restrições o segundo; isto é, cumprimen- 
tou o tenente-coronel e o major; e o orador que, para ser coerente com o que acabava de dizer, devia limitar-se a esvaziar o copo, prosseguiu da seguinte maneira:

- "O imenso acontecimento que acabamos de presenciar, senhores, creio que nunca se apagará da vossa memória. Muitas festas do Espírito Santo tem havido nesta cidade e em outras; mas nunca o povo teve o júbilo de contemplar um esplendor, uma animação, um triunfo igual ao que nos proporcionou o nosso ilustre correligionário e amigo, o tenente-coronel Veiga, honra da classe a que pertence, e glória do partido a que se filiou...

- E no qual pretendo morrer, completou o tenente-coronel.

- Nem outra coisa era de esperar de V. Ex. ${ }^{a}$, disse o orador mudando de voz para dar a estas palavras um tom de parênteses.

Apesar da declaração feita no princípio de que era inútil acrescentar nada aos méritos do tenente-coronel, o intrépido orador falou cerca de vinte e cinco minutos com grande mágoa do Padre padre Maciel, que namorava de longe um fofo e trêmulo pudim de pão, e do juiz municipal que estava ansioso por ir fumar. A peroração desse memorável discurso foi pouco mais ou menos assim:

— "Eu faltaria, portanto, aos meus deveres de amigo, de correligionário, de subordinado e de admirador, se não levantasse a voz nesta ocasião, e não vos dissesse em linguagem tosca, sim , (sinais de desaprovação), mas sincera, os sentimentos que me tumultuam dentro do peito, o entusiasmo de que me sinto possuído, quando contemplo o venerando e ilustre tenente-coronel Veiga, e se vos não convidasse a beber comigo à saúde de S. Ex. a."

O auditório acompanhou com entusiasmo o brinde do major, ao qual respondeu o tenente-coronel com estas poucas, mas sentidas palavras:

- Os elogios que me acaba de fazer o distinto major Brás, são verdadeiros favores de uma alma grande e generosa: ; não os mereço, senhores; devolvo-os intactos ao ilustre orador que me precedeu.

Todos beberam à saúde do major, que agradeceu sem saber o que era, porque desde que se sentara e daí até o fim do jantar esteve ocupado em rememorar as belas palavras que acabava de proferir.

No meio da festa e da alegria que reinava ninguém reparou nas atenções que Camilo prestava à bela filha do Dr. Matos. § Ninguém, digo mal; Leandro Soares, que fora convidado ao jantar, e assistira a ele, não tirava os olhos do elegante rival e da sua formosa e esquiva dama.

Há de parecer milagre ao leitor a indiferença e até o ar alegre com que Soares assistia aos ataques do adversário via aos ataques dos adversários. Não é milagre; Soares também interrogava o olhar de Isabel e lia nele a indiferença e , talvez o desdém, com que tratava o filho do comendador.

— Nem eu, nem ele, dizia consigo o pretendente. 
Camilo estava apaixonado; no dia seguinte amanheceu pior; cada dia que passava aumentava a chama que o consumia. Paris , e a ${ }^{8}$ princesa, tudo havia desaparecido do coração e da memória do rapaz. Um só ente, um lugar único mereciam agora as suas atenções: Isabel e Goiás.

A esquivança e os desdéns da moça não contribuíram pouco para esta transformação. §Fazendo de si próprio melhor ideia que do rival, Camilo reflexionava consigo mesmo dizia consigo:

- Se ela não me dá atenção, muito menos deve importar-se com o filho de Soares. Mas por que razão se mostra comigo tão esquiva? Que motivo há para que eu seja derrotado como qualquer pretendente vulgar?

Nessas ocasiões lembrava-se do desconhecido que the falara na igreja e das palavras que lhe dissera.

- Algum mistério haverá;dizia ele; mas como descobri-lo?

Indagou das pessoas da cidade quem era o sujeito baixo, de olhos miúdos e vivos. Ninguém lho soube dizer. Parecia incrível que não chegasse a descobrir naquelas paragens um homem que naturalmente alguém devia conhecer; redobrou de esforços; ninguém sabia quem era o misterioso sujeito.

Entretanto Camilo frequentava fazenda do Dr. Matos e ali ia jantar algumas vezes. Era difícil falar a Isabel com a liberdade que permitem mais adiantados costumes; fazia entretanto o que podia para comunicar à bela moça os seus sentimentos. Isabel parecia cada vez mais estranha às comunicações do rapaz. Suas maneiras não eram positivamente desdenhosas, mas frias; dissera-se que ali dentro morava um coração de neve.

Ao amor desprezado, veio juntar-se o orgulho ofendido, o despeito e a vergonha, e tudo isto, junto a uma epidemia que então reinava na comarca, deu com o nosso Camilo na cama, onde por agora o deixamos deixaremos, entregue aos médicos seus colegas.

Não passarei todavia a outro capítulo sem pedir desculpa ao leitor de haver empregado a expressão cama, em vez de dizer poeticamente leito da dor. São descuidos que o tempo emendará.

\section{Revelação}

Não há mistérios para um autor que sabe investigar todos os recantos do coração. Enquanto o povo de Santa Luzia faz mil conjecturas a respeito da causa verdadeira da isenção que até agora tem mostrado a formosa Isabel, estou habilitado para dizer ao leitor impaciente que ela ama.

- E a quem ama? pergunta vivamente o leitor.

\footnotetext{
${ }^{8} \mathrm{HMN}$ a,
} 
Ama... a uma parasita. Uma parasita? É verdade, uma parasita. Deve ser então uma flor muito linda, - um milagre de frescura e de aroma. Não, senhor, é uma parasita muito feia, um cadáver de flor, seco, mirrado, uma flor que devia ter sido lindíssima há muito tempo, no pé, mas que hoje na cestinha em que ela a traz, nenhum ideia sentimento inspira, a não ser de curiosidade. $\S$ Sim, porque é realmente curioso que uma moça de vinte anos, em toda a força das paixões, pareça indiferente aos homens que a cercam, e concentre todos os seus afetos nos restos descorados e secos de uma flor.

Ah! mas aquela flor foi colhida em circunstâncias especiais. Dera-se o caso alguns anos antes. Um moço da localidade gostava então muito de Isabel, porque era uma criança engraçada, e costumava chamá-la sua mulher, gracejo inocente que o tempo não sancionou. \& Isabel também gostava do rapaz, a ponto de fazer nascer no espírito do pai da moça a seguinte ideia:

- Se daqui a alguns anos as coisas não mudarem por parte dela, e se ele vier a gostar seriamente da pequena, creio que os posso casar.

Isabel ignorava completamente esta ideia do pai; mas continuava a gostar do moço, o qual continuava a achá-la uma criança interessantíssima.

Um dia viu Isabel uma linda parasita azul, entre os galhos de uma árvore.

— Que bonita flor! disse ela.

- Aposto que você a quer?

- Queria, sim... disse a menina que, sem aprender, conhecia já esse falar oblíquo e disfarçado que parece ser um talento especial do seu sexo.

$\mathrm{O}$ rapaz moço despiu o paletó com toda a sem-cerimônia de quem trata com uma criança e trepou pela árvore acima. Isabel ficou embaixo ofegante e ansiosa pelo resultado. Não tardou que o complacente moço deitasse a mão à flor e delicadamente a colhesse.

- Apanhe! disse ele de cima.

Isabel aproximou-se da árvore e recolheu a flor no regaço. § Contente por ter satisfeito o desejo da menina, tratou o rapaz de descer, mas tão desastradamente o fez, que no fim de dois minutos jazia no chão aos pés de Isabel. § A menina deu um grito de angústia e pediu socorro; o rapaz procurou tranquilizá-la dizendo que nada era, e tentando levantar-se alegremente. Levantou-se com efeito, com a camisa salpicada de sangue; tinha ferido a cabeça.

A ferida foi declarada leve; dentro de poucos dias estava o valente moço completamente restabelecido.

A impressão que Isabel recebeu naquela ocasião foi profunda. Gostava até então do rapaz; daí em diante passou a adorá-lo. A flor que ele lhe 
colhera veio naturalmente a secar; Isabel guardou-a como se fora uma relíquia; beijava-a todos os dias; e de certo tempo em diante até chorava sobre ela. Uma espécie de culto supersticioso prendia o coração da moça àquela mirrada parasita.

Aí tem o leitor o objeto de amor de Isabel.

Não era ela porém tão mau coração que não ficasse vivamente impressionada ${ }^{9}$ quando soube da doença de Camilo. Fez indagar com assiduidade do estado do moço, e cinco dias depois foi com o pai visitá-lo à fazenda do comendador.

A simples visita da moça é possível que curasse o doente; mas como a moléstia era epidêmica, a visita de Isabel apenas, se não curou o doente, deu em resultado consolar o rapaz e dar-lhe algum ânimo. Teve ainda outro efeito consolá-lo e animá-lo; viçaram-lhe algumas esperanças, que já estavam mais secas e mirradas que a parasita cuja história acima narrei.

— Quem sabe se me não amará agora? pensou ele.

Apenas ficou restabelecido foi o seu primeiro cuidado ir à fazenda do Dr. Matos; o comendador quis acompanhá-lo. § Não o acharam em casa; estavam apenas a irmã e a filha. A irmã era uma pobre velha, que além desse achaque, tinha mais dois: era surda e gostava de política. § A ocasião era boa; enquanto a tia de Isabel confiscava a pessoa e a atenção do comendador, Camilo teve tempo de dar um golpe decisivo e rápido, dirigindo à moça estas palavras:

- Agradeço-lhe a bondade que mostrou a meu respeito durante a minha moléstia. Essa mesma bondade anima-me a pedir-lhe uma coisa mais...

Isabel franziu a testa.

- Reviveu-me uma esperança há dias, continuou Camilo, esperança que já estava morta. Será ilusão minha? Uma sua palavra, um gesto seu resolverá esta dúvida.

Isabel ergueu os ombros.

- Não compreendo, disse ela.

- Compreende, disse Camilo em tom amargo. Mas eu serei mais franco, se o exige. Amo-a; disse-lho mil vezes; não fui atendido. Agora porém...

Camilo teria concluído concluiria de boa vontade este pequeno discurso, se tivesse diante de si a pessoa que ele desejava o ouvisse. Isabel, porém, não lhe deu tempo de chegar ao fim. Sem dizer palavra, sem fazer um gesto, atravessou a extensa varanda e foi sentar-se na outra extremidade onde a velha tia punha à prova os excelentes pulmões do comendador.

\footnotetext{
${ }^{9} J F$ impressionado
} 
O desapontamento de Camilo estava além de toda a descrição. Pretextando um calor que não existia saiu para tomar ar, e ora vagaroso, ora apressado, conforme triunfava nele a irritação ou o desânimo, o mísero pretendente deixou-se ir sem destino. §Construiu mil planos de vingança, ideou mil maneiras de ir lançar-se aos pés da moça, rememorou todos os fatos que se haviam dado com ela, e ao cabo de uma longa hora chegou à triste conclusão de que tudo estava perdido. §Nesse momento deu acordo de si: estava ao pé de um riacho que atravessava a fazenda do Dr. Matos. O lugar era agreste e singularmente feito para a situação em que ele se achava. A uns duzentos passos viu uma cabana, onde pareceu que alguém entoava uma cantiga do sertão.

Importuna coisa é a felicidade alheia quando a gente é somos vítima de algum infortúnio. Camilo sentiu-se ainda mais irritado, e ingenuamente perguntou a si mesmo se alguém podia ser feliz estando ele com o coração a sangrar de desespero. § Daí a nada aparecia à porta da cabana um homem e saía na direção do riacho. Camilo estremeceu; pareceu-lhe reconhecer o misterioso que lhe falara no dia do Espírito Santo. Era a mesma estatura e o mesmo ar; aproximou-se rapidamente e parou a cinco passos de distância. O homem voltou o rosto: era ele!

Camilo correu ao desconhecido.

— Enfim! disse ele.

O desconhecido sorriu-se complacentemente e apertou a mão que Camilo lhe oferecia.

— Quer descansar? perguntou-lhe.

- Não, respondeu o médico. Aqui mesmo, ou mais longe se lhe apraz, mas desde já, por favor, desejo que me explique as palavras que me disse outro dia na igreja.

Novo sorriso do desconhecido.

— Então? disse Camilo vendo que o homem não respondia.

- Antes de mais nada, diga-me; gosta deveras da moça?

- Oh! muito!

- Jura que a faria feliz?

- Juro!

- Então ouça. O que vou contar a V.S. a é verdade, porque o soube por minha mulher que foi mucama de D. Isabel. É aquela que ali está.

Camilo olhou para a porta da cabana e viu uma mulatinha alta e elegante, que olhava para ele com curiosidade.

- Agora, continuou o desconhecido, afastemo-nos um pouco; para que ela nos não ouça, porque eu não desejo venha a saber-se de quem o senhor V.S. a ouviu esta história. 
Afastaram-se com efeito costeando o riacho. §O desconhecido narrou então a Camilo toda a história da parasita, e o culto que até então a moça votava à flor já seca. §Um leitor menos sagaz imagina que o namorado ouviu essa narração triste e abatido ${ }^{10}$. Mas o leitor que souber ler adivinha logo que a confidência do desconhecido despertou na alma de Camilo os mais incríveis sobressaltos de alegria.

- Aqui está o que há, disse o desconhecido ao concluir, creio que V.S. ${ }^{a}$ com isto pode saber em que terreno pisa.

— Oh! sim! sim! disse Camilo. Sou amado! sou amado!

Sabedor daquela novidade ardia o médico por voltar à a casa, donde saíra havia tanto tempo. Meteu a mão na algibeira, abriu a carteira e tirou uma nota de vinte mil-réis.

- O serviço que me acaba de prestar é imenso, disse ele; não tem preço. Isto porém é apenas uma lembrança...

Dizendo estas palavras, estendeu-lhe a nota. § O desconhecido riu-se desdenhosamente sem responder palavra. Depois, estendeu a mão à nota que Camilo lhe oferecia, e, com grande pasmo deste, atirou-a ao riacho. O fio d'água que ia murmurando e saltando por cima das pedras, levou consigo o bilhete, de envolta com uma folha que o vento lhe levara também.

- Deste modo, disse o desconhecido, nem o senhor fica devendo um obséquio, nem eu recebo a paga dele. Não pense que tive tenção de servir a V.S. ${ }^{a}$; não. Meu desejo é fazer feliz a filha do meu benfeitor. Sabia que ela gostava de um moço, e que esse moço era capaz de a fazer feliz; abri caminho para que ele chegue até onde ela está. Isto não se paga; agradece-se apenas.

Acabando de dizer estas palavras, o desconhecido voltou as costas ao médico, e dirigiu-se para a cabana. §Camilo acompanhou com os olhos aquele homem rústico, que lhe acabava de dar tão delicadamente uma lição. Pouco tempo depois estava em casa de Isabel, onde já era esperado com alguma ansiedade. Isabel viu-o entrar, alegre e radiante.

- Sei tudo, disse-lhe Camilo pouco antes de sair.

A moça olhou espantada ${ }^{11}$ para ele.

- Tudo? repetiu ela.

- Sei que me ama, sei que esse amor nasceu há longos anos, quando era criança, e que ainda hoje...

Foi interrompido pelo comendador que se aproximava. Isabel estava pálida e confusa; e estimou a interrupção, porque não saberia que responder.

\footnotetext{
${ }^{10} J F$ abatado

${ }^{11}$ JF espantado
} 
No dia seguinte escreveu-lhe Camilo uma extensa carta apaixonada, invocando o amor que ela conservara no coração, e pedindo-lhe que o fizesse feliz. §Dois dias esperou Camilo a resposta da moça. Veio no terceiro dia. Era breve e seca. Confessava que o amara durante aquele longo tempo, e jurava não amar nunca a outro.

“Apenas isso, concluía Isabel. Quanto a ser sua esposa, nunca. Eu quisera entregar a minha vida a quem tivesse um amor igual ao meu. $\mathrm{O}$ seu amor é de ontem; o meu é de nove anos; : a diferença de idade é grande demais; não pode ser bom consórcio. Esqueça-me e adeus."

Dizer que esta carta não fez mais do que aumentar o amor de Camilo, é escrever no papel aquilo que o leitor já adivinhou. O coração de Camilo só esperava uma confissão escrita da moça para transpor o limite que o separava da loucura. A carta transtornou-o completamente.

VII

\section{Precipitam-se os acontecimentos}

O comendador não perdera a ideia de meter o filho na política. Justamente nesse ano havia eleição; o comendador escreveu às principais influências da província para que o rapaz entrasse na respectiva assembleia.

Camilo teve notícia desta premeditação do pai; limitou-se a erguer os ombros, resolvido a não aceitar coisa nenhuma que se não fosse a mão de Isabel. Em vão o pai, o Padre padre Maciel, o tenente-coronel lhe mostravam um futuro esplêndido e todo semeado de altas posições. Uma só posição o contentava: casar com a moça.

Não era fácil, decerto; a resolução de Isabel parecia inabalável.

- Ama-me, porém, dizia o rapaz consigo; é meio caminho andado.

E como o seu amor era mais recente que o dela, compreendeu Camilo que o meio de ganhar a diferença da idade, era mostrar que o tinha mais violento e capaz de maiores sacrifícios.

Não poupou manifestações de toda a sorte. Chuvas e temporais arrostou para ir vê-la todos os dias; fez-se escravo dos seus menores desejos. Se Isabel tivesse a curiosidade infantil de ver na mão a estrela d'alva, é muito provável que ele achasse meio de lha trazer.

Ao mesmo tempo cessara de a importunar com epístolas ou palavras amorosas. A última que lhe disse foi:

- Esperarei!

Nesta esperança andou ele muitas semanas, sem que a sua situação melhorasse sensivelmente. 
Alguma leitora menos exigente, há de achar singular a resolução de Isabel, ainda depois de saber que era amada. Também eu penso assim; mas não quero alterar o caráter da heroína, porque ela era tal qual a apresento nestas páginas. Entendia que ser amada casualmente, pela única razão de ter o moço voltado de Paris, enquanto ela gastara largos anos a lembrar-se dele e a viver unicamente dessa recordação, entendia, diga digo eu, que isto a humilhava, e porque era imensamente orgulhosa, resolvera não casar com ele nem com outro. Será absurdo; mas era assim.

Fatigado de assediar inutilmente o coração da moça; e por outro lado, convencido de que era necessário mostrar uma dessas paixões invencíveis a ver se a convencia e lhe quebrava a resolução, planeou Camilo um grande golpe.

Um dia de manhã desapareceu da fazenda. A princípio ninguém se abalou com a ausência do moço, porque ele costumava a dar longos passeios, quando porventura acordava mais cedo que de costume. A coisa porém começou a assustar à proporção que o tempo ia passando. Saíram emissários para todas as partes, e voltaram sem dar novas do rapaz.

O pai estava aterrado; a notícia do acontecimento correu por toda a parte em dez léguas ao redor. $\S$ No fim de cinco dias de infrutíferas pesquisas soube-se que um moço, com todos os sinais de Camilo, fora visto a meia légua da cidade, a cavalo, em viagem para o interior. Ia só e triste. Um tropeiro asseverou depois ter visto um moço junto de uma ribanceira, parecendo sondar com o olhar que probabilidade de morte lhe traria uma queda.

O comendador entrou a oferecer grossas quantias a quem lhe desse notícia segura do filho. Todos os seus amigos despacharam gente a investigar as matas e os campos, e nesta inútil labutação correu uma semana.

Será necessário dizer a dor que sofreu a formosa Isabel quando lhe foram dar notícia do desaparecimento de Camilo? A primeira impressão foi aparentemente nula nenhuma; o rosto não revelou a tempestade que imediatamente rebentara no coração. Dez minutos depois a tempestade subiu aos olhos e transbordou num verdadeiro mar de lágrimas.

Foi então que o pai teve conhecimento da paixão de tão longo tempo incubada. Ao ver aquela explosão não duvidou que o amor da filha pudesse vir a ser-lhe funesto. Sua primeira ideia foi que o rapaz desaparecera para fugir a um enlace indispensável. Isabel tranquilizou-o dizendo que, pelo contrário, era ela quem se negara a aceitar o amor de Camilo.

- Fui eu que o matei! exclamava a pobre moça.

O bom velho não compreendeu muito como é que uma moça apaixonada por um mancebo, e um mancebo apaixonado por uma moça, em vez de caminharem para o casamento, tratassem de se separar um do outro. Lembrou-se que o seu procedimento fora justamente o contrário logo que 
travou o primeiro namoro.

Apressou-se a comunicar ao comendador a causa provável do desaparecimento de Camilo; ambos reuniram os seus esforços para reaver o fugitivo mancebo.

No fim de uma semana foi o Dr. Matos procurado na sua fazenda pelo nosso já conhecido morador da cabana, que ali chegou ofegante e alegre.

— Está salvo! disse ele.

- Salvo! exclamaram o pai e a filha.

—É verdade, disse Miguel (era o nome do homem); fui encontrá-lo no fundo de uma ribanceira, quase sem vida, ontem de tarde.

- E por que não vieste dizer-nos?... perguntou o velho.

- Porque era preciso cuidar dele em primeiro lugar. Quando voltou a si quis ir outra vez tentar contra os seus dias; eu e minha mulher impedimo-lo de fazer tal. Está ainda um pouco fraco; por isso não veio comigo.

O rosto de Isabel estava radiante. Algumas lágrimas, poucas e silenciosas, ainda lhe correram dos olhos; mas eram já de alegria e não de mágoa.

Miguel saiu com a promessa de que o velho iria lá buscar o filho do comendador.

- Agora, Isabel, disse o pai apenas ficou só com ela, que pretendes fazer?

- O que me ordenar, meu pai!

— Eu só ordenarei o que te disser o coração. Que te diz ele?

- Diz...

- O quê?

- Que sim.

- É o que devia ter dito há muito tempo, porque...

$\mathrm{O}$ velho estacou.

- Mas se a causa deste suicídio for outra? pensou ele. Indagarei tudo.

Comunicada a notícia ao comendador, não tardou que este se apresentasse em casa do Dr. Matos, onde pouco depois chegou Camilo. O mísero rapaz trazia escrita no rosto a vergonha dor de haver escapado à morte trágica que procurara; pelo menos, assim o disse muitas vezes, em caminho, ao pai de Isabel.

- Mas a causa dessa resolução? perguntou-lhe o doutor.

- A causa... balbuciou Camilo que espreitava a pergunta; não ouso confessá-la...

— É vergonhosa? perguntou o velho com um sorriso benévolo.

- Oh! não!...

- Mas que causa é?

- Perdoa-me, se eu lha disser?

- Por que não? 
— Não, não ouso... disse resolutamente Camilo.

— É inútil, porque eu já sei.

- Ah!

— E perdoo a causa, mas não lhe perdoo a resolução; o senhor fez uma coisa de criança.

- Mas ela despreza-me!

- Não... ama-o!

Camilo fez aqui um gesto de surpresa perfeitamente imitado, e acompanhou o velho até a casa, onde encontrou o pai, que não sabia se devia mostrar-se severo ou satisfeito.

Camilo compreendeu logo ao entrar o efeito que o seu desastre causara no coração de Isabel.

- Ora pois! disse o pai da moça. Agora que o ressuscitamos é preciso prendê-lo à vida com uma cadeia forte.

E sem esperar a formalidade de do costume nem atender às etiquetas normais da sociedade, o pai de Isabel deu ao comendador a novidade de que era indispensável casar os filhos.

O comendador ainda não voltara a si da surpresa de ter encontrado o filho, quando ouviu esta notícia , ; e se toda a tribo dos Xavantes ${ }^{12}$ tivesse caído viesse cair em cima dele armada de arco e flecha sentiria absolutamente a mesma coisa não sentiria espanto maior. Olhou alternadamente para todos os circunstantes como se lhes pedisse a explicação razão de um fato aliás natural mui natural. § Afinal explicaram-lhe a paixão de Camilo e Isabel, causa única do suicídio meio executado pelo filho. O comendador aprovou a escolha do rapaz, e levou a sua galantaria galanteria a dizer que no caso dele teria feito o mesmo, se não contasse com a vontade da moça.

- Serei enfim digno do seu amor? perguntou o médico a Isabel quando se achou só com ela.

— Oh! sim!... disse ela. Se morresse, eu nunca me perdoaria essa desgraça cuja causa era eu só morreria também.

Camilo apressou-se a dizer que a providência Providência velara por ele; e não se soube nunca o que é que ele chamava providência Providência.

Não tardou que o desenlace do episódio trágico fosse publicado na cidade e seus arredores.

Apenas Leandro Soares soube do casamento projetado entre Isabel e Camilo ficou literalmente fora de si. Mil projetos lhe acudiram à mente, cada qual mais sanguinário; : em sua opinião eram dois pérfidos que o haviam traído; cumpria tirar uma solene desforra de ambos.

${ }^{12} J F$ Xarantes 
Nenhum déspota sonhou nunca mais terríveis suplícios do que os que Leandro Soares engendrou na sua escaldada imaginação. Dois dias e duas noites passou o pobre namorado em conjecturas estéreis. No terceiro dia resolveu ir simplesmente procurar o venturoso rival, lançar-lhe em rosto a sua vilania e assassiná-lo depois.

Muniu-se de uma faca e partiu.

Saía da fazenda o feliz noivo, descuidado da sorte que o esperava. Sua imaginação ideava agora uma vida cheia de bem-aventurança e deleites celestes; a imagem da moça dava a tudo o que o rodeava uma cor poética. Já la todo engolfado nestes devaneios quando viu em frente de si o preterido ${ }^{13}$ rival. Esquecera-se dele no meio da sua felicidade; compreendeu o perigo e preparou-se para ele.

Leandro Soares fiel ao programa que se havia imposto desfiou um rosário de impropérios que o médico ouviu calado. Quando Soares acabou e ia dar à prática o ponto final sanguinolento, Camilo disse respondeu:

- Atendi a tudo o que me disse; peço-lhe agora que me ouça. É verdade que vou casar com essa moça; mas também é verdade que ela o não ama. Qual é o nosso crime neste caso? Ora, ao passo que o senhor nutre a meu respeito $^{14}$ sentimentos de ódio, eu pensava na sua felicidade.

- Ah! disse Soares com ironia.

- É verdade. Disse comigo que um homem das suas aptidões não devia estar eternamente dedicado a servir de degrau aos outros; e então, como meu pai quer à força fazer-me deputado provincial, disse-lhe que aceitava o lugar para o dar ao senhor. Meu pai concordou; mas eu tive de vencer resistências políticas, e ainda agora trato de quebrar algumas. Um homem que assim procede creio que lhe merece alguma estima, - pelo menos não lhe merece tanto ódio.

Não creio que a língua humana possua palavras assaz enérgicas para pintar a indignação que se manifestou no rosto de Leandro Soares. O sangue subiu-lhe todo às faces, enquanto os olhos pareciam despedir chispas de fogo ${ }^{15}$. Os lábios trêmulos como que ensaiavam baixinho uma imprecação eloquente contra o feliz rival. Enfim, o pretendente infeliz rompeu nestes termos:

- A ação que o senhor praticou era já bastante infame; não precisava juntar-lhe o escárnio...

- O escárnio! interrompeu Camilo.

\footnotetext{
${ }^{13} J F$ preferido

${ }^{14} J F$ sujeito

${ }^{15} \mathrm{HMN}$ ogo
} 
- Que outro nome darei eu ao que me acaba de dizer? Grande estima, na verdade, é a sua, que depois de me roubar a maior, a única felicidade, que eu podia ter, vem oferecer-me uma compensação política!

Camilo conseguiu explicar que não lhe oferecia nenhuma compensação; pensara naquilo por conhecer as tendências políticas de Soares e julgava julgar que deste modo lhe seria agradável.

- Ao mesmo tempo, concluiu o hábil gravemente o ${ }^{16}$ noivo, fui levado pela ideia de prestar um serviço à província. Creia que em nenhum caso, ainda que me devesse custar a vida, proporia uma coisa desvantajosa à província e ao país. Eu cuidava servir a ambos apresentando a sua candidatura, e pode crer que a minha opinião será a de todos.

- Mas o senhor falou de resistências... disse Soares cravando no adversário um olhar inquisitorial.

- Resistências, não por oposição pessoal, mas por conveniências políticas, explicou Camilo. Que vale isso? Tudo se desfaz com a razão e os verdadeiros princípios do partido que tem a honra de o possuir entre seus membros.

Leandro Soares não tirava os olhos de Camilo; nos lábios pairava-lhe agora um sorriso irônico e cheio de ameaças. Contemplou-o ainda alguns instantes sem dizer palavra, até que de novo rompeu o silêncio.

- Que faria o senhor no meu caso? perguntou ele dando ao seu irônico sorriso um ar verdadeiramente lúgubre.

- Eu recusava, respondeu afoitamente Camilo.

- Ah!

- Sim, recusava, porque não tenho vocação política. Não acontece o mesmo com o senhor, que a tem, e é por assim dizer o apoio do partido em toda esta comarca.

- Tenho essa convicção, disse Soares com orgulho.

- Não é o único: todos lhe fazem justiça.

Soares entrou a passear de um lado para outro. Evidentemente esvoaçavam-lhe na mente alguns sinistros projetos Esvoaçavam-Ihe na mente terríveis inspirações, ou a humanidade reclamava alguma moderação no gênero de morte que daria ao médico. rival? \& Decorreram cinco minutos. \& Ao cabo deles, Soares parou em frente de Camilo e ex-abrupto lhe perguntou:

- Jura-me uma coisa?

- O quê?

— Que a fará feliz?

— Já o jurei a mim mesmo; é o meu mais doce dever.

\footnotetext{
${ }^{16} \mathrm{HMN}$ gravemente noivo
} 
- Seria meu esse dever se a sorte se não houvesse pronunciado contra mim; não importa; estou disposto a tudo.

- Creia que eu sei avaliar o seu grande coração, disse Camilo estendendolhe a mão.

- Talvez. O que não sabe, o que não conhece, é a tempestade que me fica na alma, a dor imensa que me há de acompanhar até a morte. Amores destes vão até a sepultura.

Parou e sacudiu a cabeça, como para expelir uma ideia sinistra.

- Que pensamento é o seu? perguntou Camilo vendo o gesto de Soares.

- Descanse, respondeu este; não tenho projeto nenhum. Resignar-meei à sorte: e se aceito essa candidatura política que me oferece é unicamente para afogar nela a dor que me abafa o coração.

Não sei se este remédio eleitoral servirá para todos os casos de doença amorosa. No coração de Soares produziu uma crise salutar, que se resolveu em favor do doente. Tanto é certo que a política sempre vale alguma coisa!

Os leitores adivinham bem que Camilo nada havia dito em favor de Soares; mas empenhou-se logo nesse sentido, e o pai com ele, e afinal conseguiu-se que Leandro Soares fosse incluído numa chapa e apresentado aos eleitores na próxima campanha. Os adversários do rapaz, sabedores das circunstâncias em que lhe foi oferecida a candidatura, não deixaram de dizer em todos os tons, que ele vendera o direito de primogenitura por um prato de lentilhas.

Havia já um ano que o filho do comendador estava casado, quando apareceu na sua fazenda um viajante francês. Levava cartas de recomendação de um dos seus professores de Paris. Camilo recebeu-o alegremente e pediu-lhe notícias da França, que ele ainda amava, dizia, como a sua pátria intelectual. $\S \mathrm{O}$ viajante disse-lhe muitas coisas, e sacou por fim da mala um maço de jornais.

Era o Figaro.

- O Figaro! exclamou Camilo ${ }^{17}$ lançando-se aos jornais como gato a bofes.

Eram atrasados, mas eram parisienses. Lembravam-lhe a vida que ele tivera durante tantos longos anos, e posto nenhum desejo sentisse de trocar por ela a vida atual, havia sempre uma natural curiosidade em despertar recordações de outro tempo.

No quarto ou quinto número que abriu deparou-se-lhe uma notícia que ele leu com espanto.

Dizia assim:

"Uma célebre Leontina Caveau, que se dizia viúva de um tal príncipe Alexis, súdito do tzar, foi ontem recolhida à prisão. A bela dama (era bela!)

\footnotetext{
${ }^{17}$ JF Camila
} 
não contente de iludir alguns moços incautos, alapardou-se com todas as joias de uma sua vizinha, Mlle. B... A roubada queixou-se a tempo de impedir a fuga da espertalhona pretendida princesa."

Camilo acabava de ler pela quarta vez esta notícia, quando Isabel entrou na sala.

- Estás com saudades de Paris? perguntou ela vendo-o tão atento a ler o jornal francês.

- Não, disse o marido, passando-lhe o braço à roda da cintura; estava com saudades de ti.

\section{2 "As bodas do Dr. Duarte" / "As bodas de Luís Duarte"}

\section{As bodas do Dr. de Luís Duarte}

Na manhã de um sábado, 25 de abril, andava tudo em alvoroço em casa de José Lemos. Preparava-se o aparelho de jantar dos dias de festa, lavavam-se as escadas e os corredores, saíam enchiam-se os leitões e os perus para serem assados no forno da padaria defronte; tudo era movimento; alguma coisa grande ${ }^{18}$ ia acontecer nesse dia.

O arranjo da sala ficou a cargo do Sr. de José Lemos. O respeitável dono da casa, trepado num banco, tratava de pregar à parede duas gravuras compradas na véspera em casa do Bernasconi; uma representava a morte de Sardanapalo Morte de Sardanapalo; outra a execução de Maria Stuart Execução de Maria Stuart. Houve alguma luta entre ele e a mulher a respeito da colocação da primeira gravura. D. Beatriz achou que era indecente um grupo de homem abraçado com tantas mulheres. Além disso, não achou lhe pareciam próprios dois quadros fúnebres em dia de festa. José Lemos, que tinha sido sócio membro de uma sociedade literária, quando era criança rapaz, respondeu triunfantemente que os dois quadros eram históricos, e que a história está bem em todas as famílias. Podia acrescentar que nem todas as famílias estão bem na história; mas este trocadilho era mais lúgubre que os quadros.

D. Beatriz, com as chaves na mão, mas sem a melena desgrenhada ${ }^{19} \mathrm{do}$ soneto de Tolentino, andava literalmente da sala para a cozinha, dando ordens, apressando as escravas, tirando toalhas e guardanapos lavados e mandando fazer compras, em suma, ocupada nas mil coisas que estão a cargo de uma dona de casa, máxime num dia de tanta ${ }^{20}$ magnitude.

\footnotetext{
${ }^{18} J F$ grande de ia

${ }^{19} \mathrm{JF}$ desgrenhada soneto

${ }^{20} \mathrm{JF}$ de tanto magnitude.
} 
De quando em quando, chegava D. Beatriz à escada que vá ia ter ao segundo andar, e gritava:

- Meninas, venham almoçar!

Mas parece que as meninas não tinham pressa, porque só depois de das nove horas acudiram ao oitavo chamado da mãe, já disposta a subir ao quarto das pequenas, o que era verdadeiro sacrifício da parte de uma senhora tão gorda.

Eram duas moreninhas de truz as filhas do casal Lemos. Uma representava ter vinte anos, outra dezessete; ambas eram altas e um tanto refeitas. A mais velha estava um pouco pálida; a outra, coradinha e alegre, desceu cantando não sei que romance do Alcazar, então em moda. Parecia que das duas a mais feliz seria a que cantava; não era; a mais feliz era a outra que nesse dia , devia ligar-se pelos laços matrimoniais a um jovem bacharel ao jovem Luís Duarte, com quem nutrira longo e porfiado namoro. Estava pálida por ter tido uma insônia terrível, doença de que até então não padecera nunca. Há doenças assim... .

Desceram as duas pequenas, tomaram a bênção à mãe, que lhes fez um rápido discurso de repreensão e foram à sala para falar ao pai. José Lemos, que pela sétima vez trocava a posição dos quadros, consultou as filhas sobre se era melhor que a stuart Stuart ficasse do lado do sofá ou do lado oposto. As meninas disseram que era melhor deixá-la onde estava, e esta opinião pôs termo às dúvidas de José Lemos que deu por concluída a tarefa e foi almoçar.

Além de José Lemos, sua mulher D. Beatriz, Carlota (a noiva) e Luísa, estavam à mesa Rodrigo Lemos e o menino Antonico, filhos também do casal Lemos. Rodrigo tinha dezoito anos e Antonico seis; o Antonico era a miniatura do Rodrigo; distinguiam-se ambos por uma notável preguiça, e nisso eram perfeitamente irmãos. Rodrigo desde as oito horas da manhã gastou o tempo em duas coisas: ler o Jornal do Comércio os anúncios do Jornal e ir à cozinha saber em que altura ia estava o almoço. Quanto ao Antonico, tinha comido às seis horas um bom prato de mingau, na forma do costume, e só se ocupou em dormir tranquilamente até que a mucama o foi chamar.

$\mathrm{O}$ almoço correu sem novidade. José Lemos era homem que comia calado; Rodrigo contou o enredo da comédia que vira na noite antecedente no Ginásio; e não se falou em outra coisa durante o almoço. Quando este acabou, Rodrigo levantou-se para ir fumar; e José Lemos encostando os braços sobre a na mesa perguntou se o tempo ameaçava chuva. Efetivamente o céu estava sombrio, e a Tijuca não apresentava bom aspecto.

Quando o Antonico ia levantar-se, impetrada a licença, ouviu da mãe este aviso: 
- Olha lá, Antonico, não faças logo ao jantar o que fazes sempre que há gente de fora.

— Que $\mathrm{O}$ que é que ele faz? perguntou José Lemos.

- Fica envergonhado e mete o dedo no nariz. Só os meninos tolos é que fazem isto: eu não quero semelhante coisa.

O Antonico ficou envergonhado com a reprimenda ${ }^{21}$ e foi para a sala lavado em lágrimas. D. Beatriz correu logo atrás para acalentar o seu Benjamim, e todos os mais se levantaram da ${ }^{22}$ mesa.

José Lemos indagou da mulher se não faltava nenhum convite, e depois de certificar-se que estavam convidados todos os que deviam assistir à festa, foi vestir-se para sair. Imediatamente foi incumbido de várias coisas: recomendar ao cabeleireiro que viesse cedo, comprar luvas para a mulher e as filhas, avisar de novo os carros, encomendar os sorvetes e os vinhos, e várias outras coisas mais em que poderia ser ajudado pelo jovem Rodrigo, se este homônimo do Cid não tivesse ido dormir para descansar o almoço.

Apenas José Lemos pôs a sola dos sapatos em contato com as pedras da rua, D. Beatriz disse a sua filha Carlota que a acompanhasse à sala, e apenas ali chegaram ambas, proferiu a boa senhora o seguinte speech:

- Minha filha, hoje termina a tua vida de solteira, e amanhã começa a tua vida de casada. Eu, que já passei pela mesma transformação, sei praticamente que o caráter de uma senhora casada traz consigo responsabilidades gravíssimas. Bom é que cada qual aprenda à sua custa; mas eu sigo nisto o exemplo de tua avó, que na véspera da minha união com teu pai, expôs em linguagem clara e simples a significação do casamento e a alta responsabilidade dessa nova posição...

D. Beatriz estacou; Carlota que atribuiu o silêncio da mãe ao desejo de obter uma resposta, não achou melhor palavra do que um beijo amorosamente filial.

Entretanto, se a noiva do bacharel de Luís Duarte tivesse espiado três dias antes pela fechadura do gabinete de seu pai, adivinharia que D. Beatriz recitava um discurso composto por José Lemos, e que o silêncio era simplesmente um eclipse de memória.

Melhor fosse fora que D. Beatriz, como as outras mães, tirasse alguns conselhos do seu coração e da sua experiência. O amor materno é a melhor retórica deste mundo. Mas o Sr. José Lemos, que conservara desde a infância juventude um sestro literário, achou que fazia mal expondo a cara-metade a alguns erros gramaticais numa ocasião tão solene.

\footnotetext{
${ }^{21} J F$ reprimanda

${ }^{22} \mathrm{JF}$ de
} 
Continuou D. Beatriz o seu discurso, que não foi longo, e terminou perguntando se realmente Carlota amava ao bacharel o noivo, e se aquele casamento não era, como podia acontecer, um resultado do de despeito. $\S \mathrm{A}$ moça respondeu que amava ao noivo sobre todas as coisas e ao próximo como a si mesma noivo tanto como a seus pais. A mãe riu do trocadilho pouco ortodoxo, e acabou beijando a filha com ternura, não estudada na prosa de José Lemos.

Pelas duas horas da tarde voltou este, suando em bicas bica, mas satisfeito de si, porque , além de ter dado conta de todas as incumbências da mulher, relativas aos carros, cabeleireiro, etc., conseguiu que o tenente Porfírio fosse lá jantar, coisa que até então estava duvidosa.

O tenente Porfírio era o tipo do orador de sobremesa; possuía o entono, a facilidade, a graça, todas as condições necessárias a esse mister. A posse de tão belos talentos proporcionava ao tenente Porfírio alguns lucros de valor; raro era o domingo ou dia de festa pública ou particular em que jantasse jantava em casa. Convidava-se o tenente Porfírio com a condição tácita de fazer um discurso, como se convida um músico para tocar alguma coisa. $\mathrm{O}$ tenente Porfírio estava entre o creme e o café; e não se cuide que era acepipe gratuito; o bom homem, se bem falava, melhor comia. De maneira que, bem pesadas as coisas, o discurso valia o jantar.

Foi grande assunto de debate nos três dias anteriores ao dia do casório das bodas, se o jantar devia preceder a cerimônia ou vice-versa. O pai da noiva inclinava-se a que o casamento fosse celebrado depois do jantar, e nisto era apoiado vivamente pelo jovem Rodrigo, que, com uma sagacidade digna de estadista, percebeu que, no caso contrário, o jantar seria muito tarde. Prevaleceu entretanto a opinião de D. Beatriz que achou esquisito ir para a igreja com a barriga cheia. Nenhuma razão teológica ou disciplinar se opunha a isso, mas a esposa de José ${ }^{23}$ Lemos tinha opiniões especiais em assunto de igreja.

Venceu a sua opinião.

Pelas quatro horas começaram a chegar os convidados.

Os primeiros foram os Vilelas, família composta de Justiniano Vilela, chefe de seção aposentado, D. Margarida, sua esposa, e D. Augusta, sobrinha de ambos.

A cabeça de Justiniano ${ }^{24}$ Vilela, - se se pode chamar cabeça a uma jaca metida numa gravata de cinco voltas, - era um exemplo da prodigalidade da natureza quando quer fazer cabeças grandes. Afirmavam, porém, algumas pessoas que o talento não correspondia ao tamanho; posto que tivesse corrido algum tempo o boato contrário. Não sei de que talento falaram

\footnotetext{
${ }^{23} \mathrm{HMN}$ de Lemos

${ }^{24} J F$ de Vilela
} 
falavam essas pessoas; e a palavra pode ter várias acepçoes aplicações. O certo é que seu um talento teve Justiniano Vilela, foi a escolha da mulher, senhora que, apesar dos seus quarenta e seis anos bem puxados, ainda merecia, no entender de José Lemos, dois dez minutos de atenção.

Trajava Justiniano Vilela como é de uso em tais reuniões; e a única coisa verdadeiramente digna de nota eram os seus sapatos ingleses de apertar no peito do pé por meio de cordões. Ora, como o marido de D. Margarida, tinha horror às calças compridas, aconteceu que apenas se sentou deixou patente a alvura de um fino e imaculado par de meias.

Além do ordenado com que foi aposentado, tinha Justiniano Vilela uma casa e dois molecotes, e com isso ia vivendo menos mal. Não gostava de política; mas tinha opiniões assentadas a respeito dos negócios públicos. Jogava o solo e o gamão todos os dias, alternadamente; gabava as coisas do seu tempo; e tomava rapé com o dedo polegar e o dedo médio.

A mulher e a sobrinha tinham entre si uma notável diferença; a mulher conservava restos de beleza, ao passo que a sobrinha era uma verdadeira penitência para quem estivesse em pecado mortal. Tendo sofrido não sei que moléstia, dois anos antes, veio a perder quase todos os cabelos, e recorreu portanto ao uso de uma cabeleira, que era a única coisa que lhe faltava para ficar uma perfeita Fúria.

Margarida, não; posto que os anos não tivessem corrido debalde para ela, via-se que um resto da antiga beleza estava a justificar os arroubos e as loucuras que por ela fez Justiniano no tempo em que a namorava. Margarida era uma graça decadente.

Outros convidados foram chegando, mas em pequena quantidade, porque à cerimônia e ao jantar só devia assistir um pequeno número de pessoas íntimas.

Às quatro horas e meia chegou o padrinho, Dr. Valença, e a madrinha, sua irmã viúva D. Virgínia. § José Lemos correu a abraçar o Dr. Valença; mas este que era homem formalista e cerimonioso, repeliu brandamente $o$ amigo, dizendo-lhe ao ouvido que naquele dia toda a gravidade era pouca. Depois, com uma serenidade que só ele possuía, entrou o Dr. Valença e foi cumprimentar a dona da casa e as outras senhoras.

Era ele homem de seus cinquenta anos, nem gordo nem magro, mas dotado de um largo peito e um largo abdômen que lhe davam maior gravidade ao rosto e às maneiras. $\mathrm{O}$ abdômen é a expressão mais positiva da gravidade humana; um homem magro tem necessariamente os movimentos rápidos; ao passo que para ser completamente grave precisa ter os movimentos tardos e medidos. Um homem verdadeiramente grave não pode gastar menos de dois minutos em tirar o lenço e assoar-se. O Dr. Valença gastava três quando estava com defluxo e quatro no estado normal. Era um homem gravíssimo.

Insisto neste ponto porque é a maior prova da inteligência do Dr. Valença. Compreendeu este advogado, logo que saiu da academia, que a 
primeira condição para merecer a estima consideração dos outros era ser grave; e indagando o que era gravidade reconheceu pareceu-lhe que não era nem o peso da reflexão, nem a seriedade do espírito, mas unicamente certo mistério do corpo, como lhe chama Larochefoucault; o qual mistério, acrescento eu acrescentará o leitor, é como a bandeira dos neutros em tempo de guerra: salva do exame a carga que cobre.

Podia-se dar uma boa gratificação a quem descobrisse uma ruga na casaca do Dr. Valença ou uma dobra na camisa que parecia uma toalha de neve. O colete tinha apenas três botões e abria-se até ao pescoço em forma de ângulo agudo coração. Um elegante claque completava a toilette do Dr. Valença. Não era ele bonito de feições no sentido afeminado que os rapazes alguns dão hoje à beleza masculina; mas não deixava de ter certa correção nas linhas do rosto, o qual se cobria de um véu de serenidade que lhe ficava a matar.

Depois da entrada dos padrinhos, José Lemos perguntou pelo noivo, e o Dr. Valença respondeu que ${ }^{25}$ não sabia dele. Eram já cinco horas. Os convidados, que cuidavam ter chegado tarde para a cerimônia, ficaram desagradavelmente surpreendidos com a demora ${ }^{26}$, e Justiniano Vilela confessou ao ouvido da mulher que estava arrependido de não ter comido alguma coisa antes. Era justamente o que estava fazendo o jovem Rodrigo Lemos, desde que percebeu que o jantar distaria viria lá para as sete horas.

A irmã do Dr. Valença de quem não falei detidamente por ser uma das figuras mais insignificantes que jamais produziu a raça de Eva, apenas entrou manifestou logo o desejo de ir ver a noiva, e D. Beatriz saiu com ela da sala, deixando plena liberdade ao marido que encetava uma conversação com a interessante esposa do Sr. Vilela.

- Os noivos de hoje não se apressam, disse filosoficamente Justiniano; quando eu me casei fui o primeiro que apareceu em casa da noiva.

Esta $A$ esta observação, toda filha do estômago implacável do ex-chefe de seção, não encontrou eco na sala; ou antes, calou no ânimo dos circunstantes, sem que ninguém ousasse apoiá-la de viva voz.

Pelo contrário, o Dr. Valença replicou respondeu dizendo:

- Compreendo a demora ,é e a comoção de aparecer diante da noiva.

Todos sorriram ouvindo esta defesa do noivo ausente, e a conversa tomou certa animação.

Justamente, no momento em que Vilela discutia com o Dr. Valença as vantagens do tempo antigo sobre ${ }^{27}$ o tempo atual, e as moças conversavam entre si do último corte dos vestidos, entrou na sala a noiva, escoltada

\footnotetext{
${ }^{25} \mathrm{HMN}$ qne

${ }^{26} J F$ de mora

${ }^{27}$ HMN sobro
} 
pela mãe e pela madrinha, vindo logo na retaguarda a interessante Luísa, acompanhada do jovem Antonico.

Eu não seria romancista narrador exato nem de bom gosto se não dissesse que houve na sala um murmúrio de admiração.

Carlota estava efetivamente deslumbrante com o seu vestido branco, e a sua grinalda de flores de laranjeira, e o seu finíssimo véu, sem outra joia mais que os seus olhos negros, verdadeiros diamantes da melhor água.

José Lemos interrompeu a conversa em que estava com a esposa de Justiniano, e contemplou a filha. , com a mesma admiração e orgulho com que Luís de Camões contemplaria uma rica edição das Lusíadas. § Foi a noiva apresentada aos convidados, e conduzida para o sofá, onde se sentou entre a madrinha e o padrinho. Este, pondo o claque em pé sobre a perna, e sobre o claque a mão apertada numa luva de três mil e quinhentos, disse à afilhada palavras de louvor que a moça ouviu corando e sorrindo, aliança amável de vaidade e modéstia.

Ouviram-se passos na escada, e já o Sr. José Lemos esperava ver entrar o futuro genro, quando assomou à porta o grupo dos irmãos Valadares.

Destes dois irmãos, o mais velho, que se chamava Calisto, era um homem amarelo, nariz aquilino, cabelos castanhos e olhos redondos. Chamavase o mais moço Eduardo, e só diferençava do irmão na cor, que era vermelha. Eram ambos empregados numa Companhia, e ambos estavam na flor dos quarenta para cima. Outra diferença havia: era que Eduardo cultivava a poesia quando as cifras lho permitiam, ao passo que o irmão era inimigo de tudo o que cheirava a literatura.

Passava o tempo, e nem o noivo, nem o tenente Porfírio davam sinais de si. O noivo era essencial para o casamento, e o tenente para o jantar. Eram cinco e meia quando apareceu finalmente o Dr. Luís Duarte. Houve um Gloria in excelsis Deo no interior de todos os convidados.

o Dr. Luís Duarte apareceu à porta da sala, e daí mesmo fez uma cortesia geral, cheia de graça e tão cerimoniosa que o padrinho lha invejou. § Era um rapaz de vinte e cinco anos, tez muito mui alva, bigode louro e sem barba nenhuma. Trazia o cabelo apartado no centro da cabeça como o atual príncipe de Metternich. Os lábios eram tão rubros que um dos Valadares disse ao ouvido do outro: Parece que os tingiu. Em suma, o Dr. Luís Duarte era uma figura capaz de fascinar agradar a uma moça de vinte anos, e eu não teria grande repugnância em chamar-lhe um Adônis, se ele não tivesse os olhos vesgos. Não eram vesgos ambos; um é que era vesgo, de maneira que quando Duarte fitava a gente, parecia empregar apenas um dos olhos, indo procurar com o outro um vizinho ausente. realmente o fosse. Mas não era. $\S$ Como a maior parte dos convidados julgava que o casamento já estaria celebrado, tinham ido embora os carros, de maneira que apenas Dada a hora, saíramos os noivos, os pais e os padrinhos, e foram à igreja, que ficava perto; os outros convidados ficaram em casa, fazendo as honras dela a menina Luísa e o jovem Rodrigo, a quem o pai foi 
chamar, e que apareceu logo trajado no rigor da moda.

— É um par de pombos, disse a Sra. D. Margarida Vilela, apenas saiu a comitiva.

—É verdade! disseram em coro os dois irmãos Valadares , e Justiniano Vilela, sendo que este disse aquilo com o mesmo ar com que diria: Temos uma bela noite.

A menina Luísa, que era alegre por natureza, alegrou a situação, conversando com as outras moças, uma das quais, a convite seu, foi tocar alguma coisa ao piano. §Calisto Valadares suspeitava que houvesse uma omissão nas Escrituras sagradas, e vinha a ser que entre as pragas do Egito devia ter figurado o piano. Imagine o leitor com que cara viu ele sair uma das moças do seu lugar e dirigir-se ao fatal instrumento. Soltou um longo suspiro e começou a contemplar as duas gravuras compradas na véspera.

- Que magnífico é isto! exclamou ele diante de do Sardanapalo Sardanapalo, quadro que ele achava detestável.

- Foi papai quem escolheu, disse Rodrigo, e foi essa a primeira palavra que pronunciou desde que entrou na sala.

- Pois, senhor, tem bom gosto, continuou Calisto; não sei se conhecem o assunto do quadro...

— O assunto é Sardanapalo Sardanapalo, disse afoitamente Rodrigo com aquele ar convicto de quem afirma uma coisa que ninguém pode negar.

- Bem sei, retrucou Calisto, estimando que a conversa pegasse; mas eu pergunto se...

Não pôde acabar; soaram os primeiros compassos.

Eduardo, que na sua qualidade de poeta, devia amar a música, aproximouse do piano e inclinou-se sobre ele na posição melancólica de um homem que conversa com as musas. §Quanto ao irmão, furioso por não poder tendo podido evitar a cascata de notas, foi sentar-se ao pé de Vilela, com quem travou conversa, começando por perguntar que horas eram no relógio dele. $\S$ Era tocar na tecla mais preciosa do ex-chefe de seção.

- É já tarde, disse este com voz fraca; olhe, seis horas.

- Não podem tardar muito.

- Eu sei! A cerimônia é longa, e talvez não achem o padre... Os casamentos deviam fazer-se em casa e de noite.

- É a minha opinião.

Vilela, que tinha feito repetidos movimentos com as pernas, trazia já as calças muito levantadas, de maneira que além das meias, já lhe apareciam as ceroulas.

A moça terminou o que estava tocando; Calisto suspirou. Eduardo, que estava encostado ao piano, cumprimentou a executante com entusiasmo.

- Por que não toca mais alguma coisa? disse ele.

- É verdade, Mariquinha Mariquinhas, toca alguma coisa da Sonâmbula, disse Luísa obrigando a amiga a sentar-se. 
- Sim! a Son...

Eduardo não pôde acabar; viu em frente os dois olhos furibundos repreensivos do irmão e fez uma careta. Interromper uma frase e fazer uma careta é quase sempre podia ser indício de um calo. Todos assim pensaram, exceto Vilela, que, julgando os outros por si, ficou convencido de que algum grito agudo do estômago tinha interrompido a voz de Eduardo. §E, como acontece às vezes, a dor alheia despertou a própria, de maneira que o estômago de Vilela formulou um verdadeiro ultimatum, ao qual o homem cedeu, aproveitando a intimidade que tinha na casa e indo ao interior sob pretexto de dar exercício às pernas.

Foi uma felicidade.

A mesa, que já tinha em cima de si alguns acepipes convidativos, apareceu como uma verdadeira fonte de Moisés aos olhos do ex-chefe de seção. § Dois pastelinhos e uma croquette foram os parlamentares que Vilela mandou ao estômago rebelado e com os quais o rebelde aquela víscera se conformou.

No entanto D. Mariquinha Mariquinhas fazia maravilhas ao piano, ; Eduardo encostado à janela parecia meditar um suicídio, ao passo que o irmão brincando com a corrente do relógio ouvia umas confidências de D. Margarida a respeito do mau serviço dos escravos. Quanto a Rodrigo, passeava de um lado para outro, dizendo de vez em quando em voz alta:

- Já tardam!

Eram seis horas e um quarto; nada de carros; algumas pessoas já estavam impacientes. Às seis e vinte minutos ouviu-se um rumor de rodas; Rodrigo correu à janela: era um tílburi. Às seis e vinte e cinco minutos todos supuseram ouvir o rumor dos carros.

- É agora, exclamou uma voz.

Não era nada. Pareceu-lhes ouvir por um efeito (desculpem a audácia com que eu caso este substantivo a este adjetivo) por um efeito de miragem auricular.

Às seis horas e trinta e oito minutos apareceram os carros. § Grande alvoroço na sala; as senhoras correram às janelas. Os homens olharam uns para os outros como conjurados que medem as suas forças para uma grande empresa. § Toda a comitiva entrou. § As escravas da casa, que espreitavam do corredor a entrada dos noivos, causaram uma verdadeira surpresa à sinhá moça deitando-lhe sobre a cabeça um dilúvio de folhas de rosa. $\S$ Cumprimentos e beijos, houve tudo quanto se faz em tais ocasiões. A noiva foi sentar-se no sofá com o marido ao pé e por felicidade sentou-se do lado esquerdo, de maneira que quando ele contemplasse a execução de Maria Stuart, que lhe ficava em frente, não deixaria de olhar para a noiva, graças à enfermidade aludida em um dos períodos acima.

O Sr. José Lemos estava contentíssimo, mas caiu-lhe água na fervura quando soube que o tenente Porfírio não tinha chegado. 
- É preciso mandá-lo chamar.

- A esta hora! murmurou Calisto Valadares.

- Sem o Porfírio não há festa completa, disse o Sr. José Lemos confidencialmente ao Dr. Valença.

- Papai, disse Rodrigo, eu creio que ele não vem.

- É impossível!

- São quase sete horas.

- E o jantar já nos espera, acrescentou D. Beatriz.

$\mathrm{O}$ voto de $\mathrm{D}$. Beatriz pesava muito no ânimo de José Lemos; por isso não insistiu. Não houve remédio senão sacrificar o tenente.

Mas o tenente era o homem das situações difíceis, o salvador dos lances arriscados. Mal acabava D. Beatriz de falar, e José Lemos de assentar assentir mentalmente à opinião da mulher, ouviu-se na escada a voz do tenente Porfírio. O dono da casa soltou um suspiro de alívio e satisfação. Entrou na sala o longamente esperado conviva.

Pertencia o tenente a essa classe feliz de homens que não têm idade, ; uns lhe davam 30 anos, outros 35 e outros 40; alguns chegavam até os 45 , e tanto esses como os outros podiam ter igualmente razão. A todas as hipóteses se prestavam a cara e as suíças castanhas do tenente. Era ele magro e de estatura meã; vestia com certa graça, e, comparado com um boneco não havia grande diferença. A única coisa que destoava um pouco era o modo de pisar; o tenente Porfírio pisava para fora $\mathrm{tal}^{28}$ ponto, que da ponta do pé esquerdo à ponta do pé, direito, quase se podia traçar uma linha reta. $\S$ Mas, como tudo tem compensação, usava ele sapatos rasos de verniz, mostrando um fino par de meias de fio de Escócia mais lisas que a superfície de uma bola de bilhar.

Entrou com a graça que lhe era peculiar. Para cumprimentar os noivos arredondou o braço direito, pôs a mão atrás das costas segurando o chapéu, e curvou profundamente o busto, ficando em posição que fazia lembrar (de longe!) os antigos lampiões das nossas ruas.

Porfírio tinha sido tenente do exército, e dera baixa, com o que andou perfeitamente, porque entrou no comércio de madeiras trastes e já possuía algum pecúlio. \& Não era bonito, mas algumas senhoras afirmavam que apesar disso era mais perigoso que uma lata de nitroglicerina. Naturalmente não devia essa qualidade à graça da linguagem, pois falava sibilando muito a letra ss; dizia sempre: Asss minhasss botasss...

Quando Porfírio acabou os cumprimentos, disse-lhe o dono da casa:

— Já sei que hoje temos coisa boa!

${ }^{28} \mathrm{HMN}$ atal 
- Qual! respondeu ele com uma modéstia exemplar; quem ousará levantar a voz diante de ilustrações?

Porfírio disse estas palavras pondo os quatro dedos da mão esquerda no bolso do colete, gesto que ele praticava por não saber onde havia de ir pôr aquele fatal braço, obstáculo dos atores novéis.

- Mas por que veio tarde? perguntou D. Beatriz.

- Condene-me, minha senhora, mas poupe-me a vergonha de explicar uma demora que não tem atenuante no código da amizade e da polidez.

José Lemos sorriu olhando para todos e como se destas palavras do tenente lhe resultasse alguma glória para ele. Mas Justiniano Vilela que, apesar dos pastelinhos, sentia-se impelido para mesa, exclamou velhacamente:

- Felizmente chegou à hora de jantar!

— É verdade; vamos para a mesa, disse José Lemos dando o braço a D. Margarida e a D. Virgínia. Seguiram-se os mais em procissão.

Não há mais júbilo nos peregrinos da Meca do que houve nos convivas ao avistarem uma longa mesa, propriamente profusamente servida, alastrada de porcelanas $^{29}$ e cristais, assados, doces e frutas. §Sentaram-se na ordem usual em boa ordem. Durante alguns minutos houve aquele silêncio que precede as batalhas a batalha , sendo esta alegoria tão perfeita, que até o tinir das espadas era ali imitado pelo ruído das colheres nos pratos. O exército atacou resolutamente a sopa; fez depois um reconhecimento nos ensopados; avançou para o esquadrão dos guisados; tomou à viva força o baluarte de um peru; e só depois destas grandes proezas é que se travou geral conversa. Antes disso falavam, mas a meia voz, quanto bastasse para não disfarçar a onipotência do estômago no fim dela, começou a geral conversação.

- Quem diria há um ano, quando eu aqui apresentei o nosso Duarte que ele seria hoje noivo desta interessante D. Carlota? disse o Dr. Valença limpando os lábios com o guardanapo, e lançando um rápido benévolo olhar para a noiva.

— É verdade! disse Beatriz.

- Parece dedo da Providência, opinou a mulher de Vilela.

- Parece, e é, disse D. Beatriz.

- Se é o dedo da Providência, acudiu o noivo, agradeço aos céus o interesse que toma por mim.

Sorriu D. Carlota, e José Lemos achou o dito de bom gosto e digno de um genro.

- Providência ou acaso? perguntou o tenente. Eu sou mais pelo acaso.

- Vai mal, disse Vilela que, pela primeira vez levantara a cabeça do prato; isso que o senhor chama acaso não é senão a Providência. O casamento e a mortalha no céu se talha.

\footnotetext{
${ }^{29} \mathrm{HMN}$ procelanas
} 
- Ah! o sr. senhor acredita nos provérbios?

— É a sabedoria das nações, disse José Lemos.

- Não, insistiu o tenente Porfírio. Repare que para cada provérbio afirmando uma coisa, há outro provérbio afirmando a coisa contrária. Os provérbios mentem. Eu creio que foi simplesmente um felicíssimo acaso, ou antes uma lei de atração das almas que fez com que o Dr. Sr. Luís Duarte se aproximasse da interessante filha do nosso anfitrião.

José Lemos ignorava até aquela data se era anfitrião; mas considerou que da parte de Porfírio não podia vir coisa má. Agradeceu sorrindo o que lhe pareceu cumprimento, enquanto se servia da gelatina, que Justiniano Vilela dizia estar excelente.

As moças conversavam baixinho e sorrindo; os noivos estavam embebidos com a troca de palavras amorosas, ao passo que Rodrigo palitava os dentes com tal ruído, que a mãe não pôde deixar de lhe lançar um desses olhares fulminantes que são as melhores armas de uma dona de casa eram as suas melhores armas.

- Quer gelatina, Sr. Calisto? perguntou José Lemos com a colher no ar.

- Um pouco, disse o homem de cara amarela.

- A gelatina é excelente! disse pela terceira vez o marido de D. Margarida, e tão envergonhada ficou a mulher com este disparate do homem, estas palavras do homem que não pôde reter um gesto de desgosto. Mas ao mesmo tempo olhou para ele, e pela primeira vez reparou que o peito da camisa de Justiniano tinha duas lágrimas de molho, - coisa que não podia deixar de acontecer pois não pusera guardanapo ao pescoço, como fazia em casa.

- Meus senhores, disse o padrinho, eu bebo aos noivos.

- Bravo! disse uma voz.

— Só isso? perguntou Rodrigo; deseja-se uma saúde historiada.

- Mamãe! eu quero gelatina! disse o menino Antonico.

— Eu não sei fazer discursos; bebo simplesmente à saúde dos noivos.

Todos beberam à saúde dos noivos.

— Quero gelatina! insistiu o filho de José Lemos.

D. Beatriz sentiu ímpetos de Medeia; a atenção pelos o respeito aos convidados impediu que ali houvesse uma cena de sangue grave. A boa senhora limitou-se a dizer a um dos serventes:

- Leva isto a nhonhô...

O Antonico recebeu o prato, e entrou a comer como comem as crianças quando não têm vontade: levava um colherada à boca e demorava demorava-se tempo infinito rolando o conteúdo da colher entre a língua e o paladar, ao passo que a colher, empurrada por um lado formava na bochecha direita uma pequena elevação. § Ao mesmo tempo agitava o pequeno as pernas de maneira que batia alternadamente na cadeira e na mesa.

D. Beatriz estava em brasas. 
Enquanto se davam estes incidentes, em que ninguém realmente reparava, a conversa continuava o seu caminho. O Dr. Valença discutia com uma senhora a excelência do vinho Xerez, e Eduardo Valadares, recitava uma décima à moça que lhe ficava ao pé.

De repente levantou-se José Lemos.

— Sio! sio! sio! gritaram todos impondo silêncio.

José Lemos pegou num copo e disse aos circunstantes:

- Não é, meus senhores, a vaidade de ser ouvido por tão notável assembleia que me obriga a falar. É um alto dever de cortesia, de amizade, de gratidão; um desses deveres que podem mais que todos os outros, dever santo, dever imortal.

Era impossível compor um acervo de palavras mais ocas do que estas ; mas $A$ estas palavras a assembleia seria bem cruel se as cruel se não aplaudisse. O aplauso não atrapalhou o orador, pela simples razão de que ele sabia o discurso de cor.

- Sim, senhores. Curvo-me a esse dever, que é para mim a lei mais santa e imperiosa. Eu bebo aos meus amigos, a estes sectários do coração, a estas vestais, tanto masculinas como femininas, do puro fogo da amizade! Aos meus amigos! à amizade!

A falar verdade, o único homem que percebeu a nulidade do discurso de José Lemos foi o Dr. Valença, que aliás não era águia. Por isso mesmo levantou-se e fez um brinde aos talentos oratórios do anfitrião.

Seguiu-se a estes dois brindes o silêncio de uso, até que Rodrigo dirigindose ao tenente Porfírio perguntou-lhe se havia deixado a musa em casa.

—É verdade! queremos ouvi-lo, disse uma senhora; dizem que fala tão bem!

— Eu, minha senhora? respondeu Porfírio com aquela modéstia de um homem que se supõe um S. João Crisóstomo Boca de Ouro.

Distribuiu-se o champanhe; e o tenente Porfírio levantou-se. Vilela, que se achava um pouco distante, pôs a mão em forma de concha atrás da orelha direita, ao passo que Calisto fincando um olhar profundo sobre a toalha parecia estar contando os fios do tecido. José Lemos chamou a atenção da mulher, que nesse momento servia uma castanha gelada ao implacável Antonico; todos os mais estavam com os olhos no orador.

— Minhas senhoras! meus senhores! disse Porfírio; não irei esquadrinhar no âmago da história, essa mestra da vida, o que era o himeneu nas priscas eras da humanidade. Seria lançar a luva do escárnio às faces imaculadas desta brilhante reunião. Todos nós sabemos, senhoras e senhores, o que é o himeneu. O himeneu é a rosa, rainha dos vergéis, abrindo as pétalas rubras, para amenizar os cardos, os abrolhos, os espinhos da vida...

- Bravo!

- Bonito! 
- Se o himeneu é isto o que eu acabo de expor aos vossos sentidos auriculares, não é mister explicar o gáudio, o fervor, os ímpetos de amor, as explosões de sentimento com que todos nós estamos à roda deste altar, celebrando a festa do nosso caro e prezadíssimo amigo.

José Lemos curvou a cabeça até tocar com a ponta do nariz numa pera que tinha diante de si, enquanto D. Beatriz voltando-se para o Dr. Valença, que lhe ficava ao pé, dizia:

— Fala muito bem! parece um dicionário!

José Porfírio continuou:

- Sinto, senhores, não ter um talento digno do assunto...

— Não apoiado! está falando muito bem! gritaram disseram muitas vozes em volta do orador.

- Agradeço a bondade de V. Ex. ${ }^{\text {as }}$; mas eu persisto na crença de que não tenho o talento capaz de arcar com um objeto de tanta magnitude.

- Não apoiado!

- V. Ex. ${ }^{\text {as }}$ confundem-me, respondeu Porfírio curvando-se. Não tenho esse talento; mas sobra-me boa vontade, aquela boa vontade com que os apóstolos plantaram no mundo a religião do Calvário, e graças a este sentimento poderei resumir em duas palavras o brinde aos noivos. Senhores, duas flores nasceram em diverso canteiro, ambas pulcras, ambas rescendentes, ambas cheias de vitalidade divina. Nasceram uma para outra; era o cravo e a rosa; a rosa vivia para o cravo, o cravo vivia para a rosa: veio uma brisa e comunicou os perfumes das duas flores, e as flores, conhecendo que se amavam, correram uma para a outra. A brisa abençoou apadrinhou essa união. A rosa e o cravo ali estão consorciados no amplexo da simpatia: a brisa ali está honrando a nossa reunião.

Ninguém esperava pela brisa; a brisa era o Dr. Valença.

Estrepitosos aplausos celebraram este discurso em que o Calvário, já tão estafado pelos poetas, andou unido ao cravo e à rosa. Porfírio sentou-se com a satisfação íntima de ter cumprido o seu dever.

O jantar chegava ao fim: eram oito horas e meia; vinham chegando alguns músicos para o baile. Todavia, ainda houve uma poesia de Eduardo Valadares e alguns brindes a todos os presentes e a alguns ausentes. Ora, como o vinho ia os licores iam ajudando as musas, travou-se especial combate entre o tenente Porfírio e Justiniano Vilela, que, só depois de animado, pôde entrar na arena. Esgotados os assuntos, fez Porfírio um brinde ao exército e aos seus generais, e Vilela outro à união das províncias do império. Neste terreno os assuntos não podiam escassear. Quando todos se levantaram da mesa, lá ficaram os dois brindando calorosamente todas as ideias práticas e úteis deste mundo, e do outro. 
Seguiu-se o baile, que foi animadíssimo e durou até as três horas da manhã.

Nenhum incidente perturbou esta festa. Quando muito podia citarse um ato de mau gosto da parte de José Lemos que, dançando com D. Margarida, ousou lamentar a sorte dessa pobre senhora cujo marido se entretinha a fazer saúdes em vez de ter a inapreciável ventura de estar ao lado dela. D. Margarida sorriu; mas o incidente não foi adiante.

Às duas horas retirou-se o Dr. Valença com a família, sem que durante a noite, e apesar da familiaridade da reunião, perdesse um átomo sequer da gravidade habitual. Calisto Valadares esquivou-se na ocasião em que a filha mais moça de D. Beatriz ia cantar ao piano. Os mais foram-se retirando a pouco e pouco.

Quando a festa acabou de todo, ainda os dois últimos Abencerragens do copo e da mesa lá estavam levantando brindes de todo o tamanho. $\mathrm{O}$ último brinde de Vilela foi ao progresso do mundo pelo por meio do café e do algodão, e o de Porfírio à ascensão da democracia ao estabelecimento da paz universal.

Mas o verdadeiro brinde dessa festa memorável, foi um pecurrucho que viu a luz em janeiro do ano seguinte, o qual perpetuará a dinastia dos Lemos, se não morrer na crise da dentição.

\section{3 "Ernesto de tal"}

\section{Ernesto de tal}

Aquele moço que ali está parado na rua Nova do Conde esquina do Campo da Aclamação, às dez horas da noite, não é nenhum ladrão, não é sequer um filósofo. Tem um ar misterioso, é verdade; de quando em quando leva a mão ao peito, bate uma palmada na coxa, ou atira fora um charuto apenas encetado. Filósofo, já se vê que não era. Ratoneiro também não; se algum sujeito acerta de passar pelo mesmo lado, o vulto afasta-se cauteloso, como se tivesse medo de ser conhecido.

De dez em dez minutos, sobe a rua até o lugar em que ela faz ângulo com a rua do Areal, torna a descer dez minutos depois, para de novo subir e descer, descer e subir, sem outro resultado mais que aumentar cinco por cento $\mathrm{a}^{30}$ cólera que lhe murmura no coração.

\footnotetext{
${ }^{30} J F$ à cólera
} 
Quem o visse fazer estas subidas e descidas, bater na perna, acender e apagar charutos, e não tivesse outra explicação, suporia plausivelmente que o homem estava doido ou perto disso. ${ }^{31}$ Não, senhor; Ernesto de tal ${ }^{32}$ (não estou autorizado para dizer o nome todo) anda simplesmente apaixonado por uma moça que mora naquela rua; está colérico porque ainda não conseguiu receber resposta da carta que lhe mandou nessa manhã.

Convém dizer que dois dias antes tinha havido um pequeno arrufo. Ernesto quebrara o protesto de namorado que lhe fizera, de nunca mais escrever-lhe, mandando nessa manhã uma epístola de quatro laudas incendiárias, com muitos sinais admirativos e vários descuidos várias liberdades de pontuação. A carta foi, mas a resposta não veio.

De cada vez que o nosso namorado operava a descida ou subida da rua, parava defronte de uma casa assobradada, onde se dançava ao som de um piano. Era ali que morava a dama dos seus pensamentos. Mas parava debalde; nem ela aparecia à janela, nem a carta lhe chegava às mãos.

Ernesto mordia então os beiços para não soltar ${ }^{33}$ um grito de desespero e ia desafogar os seus furores na próxima esquina.

- Mas que explicação tem isto? dizia ele consigo mesmo; por que razão não me atira ela o papel de cima da janela? Não tem que ver; está toda entregue à dança, talvez ao namoro, não se lembra que eu estou aqui na rua, quando podia estar lá...

Neste ponto calou-se o namorado, e em vez do gesto de desespero que devia fazer, soltou apenas um longo e magoado suspiro. § A explicação deste suspiro, inverossímil num homem que está rebentando de cólera, é um tanto delicada para se dizer em letra redonda. Mas vá lá; ou não se há de contar nada, ou se há de dizer tudo.

Ernesto dava-se em casa do Sr. Vieira, tio de Rosina, que é o nome da namorada. Lá continuava costumava ir com frequência, e lá mesmo é que se arrufou com ela dois dias antes deste sábado de outubro de 1850, em que se passa o acontecimento que estou narrando. Ora, por que razão não figura Ernesto entre os cavalheiros que estão dançando ou tomando chá? § $\mathrm{Na}$ véspera de tarde o Sr. Vieira, encontrando-se com Ernesto, participou-lhe que dava no dia seguinte uma pequena partida para solenizar não sei que acontecimento imprevisto da família.

- Resolvi isto hoje de manhã, concluiu ele; convidei pouca gente, mas espero que a festa esteja brilhante. Ia mandar-lhe agora um convite; mas creio que me dispensa?...

\footnotetext{
${ }^{31} \mathrm{HMN}$ disso,

${ }^{32} J F$ de ta

${ }^{33} J F$ saltar
} 
- Sem dúvida, apressou-se a dizer Ernesto esfregando as mãos de contente.

- Não falte!

- Não, senhor.

- Ah! esquecia-me avisá-lo de uma coisa, disse Vieira que já havia dado alguns passos; como vai o subdelegado, que além disso é comendador, eu desejava que todos os meus convidados aparecessem de casaca. Sacrifiquese à casaca, sim?

- Com muito gosto, respondeu o outro ficando pálido como um defunto.

Ernesto não tinha casaca! Pálido, por quê? Leitor, por mais ridícula e lastimosa que te pareça esta declaração, não hesito de dizer-te que o nosso Ernesto não possuía uma só casaca nova nem velha. §A exigência de Vieira era absurda; mas não havia fugir-lhe; : ou não ir, ou ir de casaca.

Gravíssima era a situação. Cumpria sair dela a todo custo.

Como? Cumpria sair a todo o custo desta gravíssima situação. §Três alvitres se apresentaram diante do ao espírito atribulado do do atribulado moço: encomendar, por qualquer preço, uma casaca para a noite seguinte; tomá-la comprá-la a crédito; pedi-la a um amigo.

Os dois primeiros alvitres foram desprezados por impraticáveis: ; Ernesto não tinha dinheiro nem crédito tão alto. § Restava o terceiro. § Dotado de um grande espírito de ordem e regularidade, o rapaz fez Fez Ernesto uma lista dos amigos e casacas prováveis, meteu-a na algibeira , e saiu em busca do velocino.

A desgraça porém que o perseguia fez com que o primeiro amigo tivesse de ir no dia seguinte a um casamento e o segundo a um baile; o terceiro tinha a casaca rota, o quarto tinha a casaca empenhada emprestada, o quinto não emprestava a casaca, o sexto não tinha casaca. Recorreu ainda a mais dois amigos suplementares; mas um partira na véspera para Iguaçu e o outro estava destacado na fortaleza de S. João como alferes da guarda nacional.

Imagine-se o desespero de Ernesto; mas admire-se também a requintada crueldade com que o destino tratava a este moço, que ao voltar para casa encontrou três enterros, dois dos quais com muitos carros, todos cheios de homens encasacados. cujos ocupantes iam todos de casaca. §Era mister curvar a cabeça à fatalidade; Ernesto não insistiu. § Mas como tomara a peito reconciliar-se com Rosina, escreveu-lhe a carta de que falei acima e mandou-a levar pelo moleque da casa, dizendo-lhe que à noite lhe desse a resposta na esquina do Campo. §Já sabemos que tal resposta não veio. Ernesto não compreendia a causa do silêncio; muitos arrufos tivera com a moça, e mas nenhum deles resistia à primeira carta nem durava mais de quarenta e oito horas.

Desenganado enfim de que a resposta viesse naquela noite, Ernesto dirigiu-se para casa com o desespero no coração. Morava na rua da Misericórdia. Quando lá chegou estava cansado e abatido. Nem por isso dormiu 
logo. Despiu-se precipitadamente. Esteve a ponto de rasgar o colete, cuja fivela teimava em prender-se a um botão da calça. Atirou com as botinas sobre um aparador e quase esmigalhou uma das jarras. Deu cerca de sete ou oito murros na mesa; fumou dois charutos, descompôs o destino, a moça, a si mesmo, até que sobre a madrugada pôde conciliar o sono.

Enquanto ele dorme indaguemos a causa do silêncio da namorada.

\section{II}

Veja o leitor aquela moça que ali está, sentada num sofá, entre duas raparigas damas da mesma idade, conversando baixinho com elas, e requebrando de quando em quando os olhos. § É Rosina. § Os olhos de Rosina não enganam ninguém... exceto os namorados. Os olhos dela são espertinhos e caçadores, e com um certo movimento que ela lhes dá, ficam ainda mais caçadores e espertinhos. § É galantinha, galante e graciosa; se o não fora, não se deixaria prender por ela o nosso infeliz Ernesto, que era rapaz de apurado gosto. Alta não era, mas baixinha, viva, petulante travessa. Tinha bastante afetação nos modos e no falar; mas Ernesto, a quem um amigo notara isso mesmo, declarou que não gostava de moscas mortas.

- Eu nem de moscas vivas, acudiu o amigo encantado por ter apanhado no ar este trocadilho.

Trocadilho de 1850.

Não veste com luxo porque o tio não é rico; mas ainda assim está garrida e elegante. Na cabeça tem por enfeite apenas dois laços de fita azul.

- Ah! se aquelas fitas me quisessem enforcar! dizia um rapaz gamenho de bigode preto e cabelo partido ao meio.

- Se aquelas fitas me quiserem quisessem levar ao céu! dizia outro rapaz de suíças castanhas e orelhas pequeninas.

Desejos inúteis ambiciosos os destes dois rapazes, - inúteis ambiciosos e vãos, porque ela, se alguém lhe prende a atenção, é um rapaz moço de bigode louro e nariz comprido que está agora a conversar conversando com o subdelegado. $\S$ Para ele é que Rosina dirige de quando em quando os olhos, com disfarce é verdade, não tanto porém que o não percebam as duas raparigas moças que estão ao pé dela.

- Namoro ferrado! dizia uma delas à outra fazendo um sinal de cabeça para o lado do moço de nariz comprido.

- Ora, Justina!

- Calúnias! acudia a outra moça.

- Cala-te, Amélia!

- Você que enganar a gente? insistia Justina. Tire o cavalo da chuva! Lá está ele olhando... Parece que nem ouve o comendador. Pobre comendador! para pau de cabeleira está grosso demais. 
-Olha, que se você não se cala eu vou-me embora, disse Rosina fingindose enfadada.

- Pois vá!

- Coitado do Ernesto! suspirou Amélia do outro lado.

- Olhe que titia pode ouvir, observou Rosina olhando ${ }^{34}$ de esguelha para uma velha gorda, que assentada ao pé do sofá, referia a uma comadre as diversas peripécias da última moléstia do marido.

- Mas por que não veio o Ernesto?!perguntou Justina.

- Mandou dizer a papai que tinha um trabalho urgente.

- Quem sabe se algum namoro também!? insinuou ${ }^{35}$ Justina com um gesto malicioso.

- Não é capaz! acudiu Rosina.

- Bravo! que confiança!

- Que amor!

- Que certeza!

- Que defensora!

- Não é capaz, repetiu a moça; o Ernesto não é capaz de namorar a outra; estou certa disso... O Ernesto é um...

Engoliu o resto.

- Um quê? perguntou Amélia.

- Um quê? repetiu perguntou Justina.

Neste momento tocou-se uma valsa, e o rapaz de nariz comprido, a quem o subdelegado deixara para ir conversar com Vieira, aproximou-se do sofá e pediu a Rosina a honra de lhe dar aquela valsa. § A moça abaixou os olhos com singular modéstia, murmurou algumas palavras que ninguém ouviu, levantou-se e foi valsar. §Justina e Amélia chegaram-se então uma para outra e comentaram o procedimento de Rosina e a sua maneira de valsar sem graça. Mas como ambas elas eram amigas de Rosina, não foram estas censuras feitas em tom ofensivo, mas com brandura, como os amigos devem censurar os amigos ausentes.

E não tinham muita razão as duas amigas. Rosina valsava com graça e podia pedir meças a quem soubesse aquele gênero de dança. Agora quanto ao namoro, pode ser que tivessem razão, e tinham efetivamente; a maneira por que esta ela olhava e falava ao rapaz de nariz comprido despertava suspeitas no espírito mais desprevenido a seu respeito.

Acabada a valsa passearam um pouco e foram depois para o vão de uma janela. Era então uma hora, e já o desgraçado Ernesto palmilhava na direção da rua da Misericórdia.

\footnotetext{
${ }^{34} J F$ olhendo

${ }^{35} \mathrm{HMN}$ insinuon
} 
- Eu passarei amanhã às seis horas da tarde.

- Às seis horas, não! disse Rosina.

Era a hora em que Ernesto costumava passar ir lá.

- Então às cinco...

- Às cinco?... Sim, às cinco, concordou a moça.

O rapaz de nariz comprido agradeceu com um sorriso esta ratificação de seu tratado amoroso, e proferiu algumas palavras que a moça ouviu derretida e envergonhada, entre vaidosa e modesta. §O que ele ${ }^{36}$ dizia era que Rosina não só era a flor do baile, mas também a flor da rua do Conde, e não só a flor da rua do Conde, mas também a flor da cidade inteira.

Isto era o que lhe dissera muitas vezes Ernesto; o rapaz de nariz comprido, entretanto, tinha uma maneira particular de elogiar uma moça. A graça , por exemplo, com que ele metia o dedo polegar da mão esquerda no bolso esquerdo do colete, brincando depois com os outros dedos como se tocasse o piano, era de todo ponto inimitável; nem havia ninguém, pelo menos, naquelas imediações, que tivesse mais elegância na maneira de arquear os braços, de consertar os cabelos, ou simplesmente de oferecer uma xícara de chá.

Tais foram os dotes que venceram o coração inconstante da graciosa Rosina. §Só esses? § Não. § A simples circunstância de não ter Ernesto a interessante vestidura que ornava o corpo e realçava as graças do seu afortunado rival, pode já dar algumas luzes ao leitor de boa fé. § Rosina ignorava sem dúvida a situação precária de Ernesto a respeito da casaca; mas não ignorava sabia que ele ocupava um emprego somenos no arsenal de guerra, ao passo que o rapaz de nariz comprido tinha um bom lugar numa casa comercial.

Uma moça que professasse ideias filosóficas a respeito do amor e do casamento diria que os impulsos do coração estavam antes de tudo. Rosina não era de todo inteiramente avessa aos impulsos do coração e à filosofia do amor; mas tinha ambição de figurar alguma coisa, morria por vestidos novos e espetáculos frequentes, gostava enfim de viver à luz pública. $\S$ Tudo isso podia dar-lhe, com o tempo, o rapaz de nariz comprido, que ela antevia já na direção da casa em que trabalhava; o Ernesto porém era difícil que passasse do lugar que tinha no arsenal, e em todo o caso não subiria muito nem depressa.

Pesados $^{37}$ os merecimentos de um e de outro, quem perdia era o mísero Ernesto.

\footnotetext{
${ }^{36} \mathrm{JF}$ ela

${ }^{37}$ JF Parados
} 
Rosina conhecia já o novo candidato desde algumas semanas, ; mas só naquela noite tivera ocasião de entreter relações telegráficas com ele.é difícil dizer quantos telegramas foram trocados durante a noite entre as duas estações;foram tantos que os Estados vizinho e limítrofes ficaram abalados com receio de perderem uma aliança provável. Alguns chamaram às armas as milícias dos agrados e requebros, dos lenços na boca, dos olhos ternos e das expressões derretidas. Esforço inútil! a aliança dos dos estava assinada. o tratar de perto, de consolidar, digamos assim, a sua situação. As relações, até então puramente telegráficas, passaram a ser verbais; e se o leitor gosta de um estilo arrebicado e gongórico, dir-lhe-ei que tantos foram os telegramas trocados durante a noite entre eles, que os Estados vizinhos, receosos de perder uma aliança provável chamaram às armas a milícia dos agrados, mandaram sair a armada dos requebros, assestaram a artilharia dos olhos tenros, dos lenços na boca, e das expressões suavíssimas; mas toda essa leva de broqueis nenhum resultado deu porque a formosa Rosina, ao menos daquela noite, achava-se entregue a um só pensamento.

Quando acabou o baile, e Rosina entrou na sua alcova, viu um papelinho dobrado no toucador.

- Que é isto? perguntou ela.

Abriu: era a resposta à carta de Ernesto que ela se esquecera de mandar. Se alguém a tivesse lido? Não; não era natural. Dobrou a cartinha com muito cuidado, fechou-a com obreia, guardou-a numa gavetinha, dizendo consigo : :

- É preciso mandá-la amanhã de manhã.

III

Um palerma - Um palerma - é o que Rosina queria dizer quando defendeu a fidelidade de Ernesto, maliciosamente atacada pelas duas amigas.

Havia apenas três meses que Ernesto namorava a sobrinha de Vieira, que se carteava com ela, que protestavam um ao outro eterna fidelidade, e nesse curto espaço de tempo tinha já descoberto cinco ou seis mouros na costa. Nessas ocasiões servia-lhe fervia-lhe a cólera, e era capaz de deitar tudo abaixo. Mas a boa menina, com a sua varinha mágica, trazia o rapaz a bom caminho, escrevendo-lhe duas linhas ou dizendo-lhe quatro palavras de fogo. Ernesto confessava que tinha visto mal, e que ela era excessivamente misericordiosa para com ele.

- Merecia bem que eu o não amasse mais, observava Rosina com gracioso enfado.

- Oh! não!

- Para que há de inventar essas coisas?

- Eu não invento... disseram-me.

- Pois fez mal em acreditar. 
- Fiz mal, sim... você é um anjo do céu!

Rosina perdoava-lhe a calúnia, e as coisas continuavam como dantes.

Um amigo , a quem Ernesto confiava todas as suas alegrias e mágoas, a quem tomava por conselheiro e que era seu companheiro de casa, muita vez muitas vezes lhe dizia:

- Olha, Ernesto, eu creio que estás perdendo o teu trabalho.

- Como assim?

- Ela não gosta de ti.

- Impossível!

- Tu és apenas um passatempo.

- Enganas-te; ama-me! .

- Mas ama também a outros muitos.

- Jorge?!

- Em suma...

- Nem mais uma palavra!

- É uma namoradeira, concluía o amigo tranquilamente.

Ouvindo este peremptório juízo do amigo, Ernesto despedia um olhar longo e profundo, capaz de paralisar todos os movimentos conhecidos da mecânica; como porém o rosto do amigo não revelasse a menor impressão de temor ou arrependimento, Ernesto recolhia o olhar,- mais cordato neste ponto que o senador D. Manoel, a quem o visconde de Jequitinhonha dizia um dia no senado que recolhesse um riso, e continuava a rir, - e tudo acabava em boa e santa paz.

Tal era a confiança de Ernesto na flor da rua do Conde. Se ela lhe dissesse um dia que tinha na algibeira do vestido uma das torres da Candelária, não é certo, mas é muito provável que Ernesto lhe aceitasse a notícia.

Desta vez porém o arrufo era sério. Ernesto vira positivamente a moça receber uma cartinha, às furtadelas, da mão de uma espécie de primo que frequentava a casa de Vieira. Seus olhos faiscaram de raiva quando viram alvejar a misteriosa epístola nas mãos da moça. Fez um gesto de ameaça ao rapaz, lançou um olhar de desprezo à moça, e saiu. Depois escreveu a carta de que temos notícia, e foi esperar a resposta na esquina da rua. Que resposta, se ele vira o gesto de Rosina? Leitor ingênuo, ele queria uma resposta que lhe demonstrasse não ter visto coisa alguma, uma resposta que o fizesse olhar para si mesmo com desprezo e nojo. Não achava possível semelhante explicação; mas no fundo d'alma era isso o que ele queria.

A resposta veio no dia seguinte. O rapaz que morava com ele foi acordálo à cama, às 108 horas da manhã, para lhe entregar uma cartinha de Rosina.

Ernesto deu um salto na cama, assentou-se, abriu a epístola, e leu leu-a rapidamente. Um ar de celeste bem-aventurança revelou ao companheiro de Ernesto o conteúdo da carta. 
- Tudo está sanado, disse Ernesto fechando a carta e descendo da cama; ela explicou tudo; eu tinha visto mal.

- Ah! disse Jorge olhando piedosamente com lástima para o amigo ; então que diz ela?

Ernesto não respondeu imediatamente; abriu a carta outra vez, leua para si, tornou a fechá-la, olhou para o teto, para as chinelas, para o companheiro, e só depois desta série de gestos indicativos da profunda abstração do seu espírito, é que respondeu a Jorge, dizendo:

- Ela explica tudo; a carta que eu pensei ser de amores, era um bilhete do primo pedindo algum dinheiro ao tio. Diz que eu sou muito mau em obrigá-la a falar nestas fraquezas de família, e conclui jurando que me ama como nunca seria capaz de amar a ninguém. Lê.

Jorge recebeu a carta e leu, enquanto Ernesto passeava de um para outro lado, gesticulando e monossilabando consigo mesmo, como se redigisse mentalmente um ato de contrição.

- Então? que tal? disse ele quando Jorge lhe entregou a carta.

- Tens razão, tudo se explica, respondeu Jorge.

Ernesto passou foi nessa mesma tarde pela à rua do Conde. Ela recebeu-o com um sorriso logo de longe. Ernesto passou duas vezes pela porta; à terceira não resistiu e entrou. Na primeira ocasião que tiveram, tudo ficou explicado, declarandose Ernesto eminentemente compungido ${ }^{38}$ por haver suspeitado de Rosina, e levando a moça a sua generosidade ao ponto de lhe ceder um beijo, ao lusco-fusco, antes que a criada viesse acender as velas de spermacetti dos aparadores.

Agora tem a palavra o leitor para interpelar-me a respeito das intenções desta moça, que preferindo a posição do rapaz de nariz comprido, ainda se carteava com Ernesto, e lhe dava todas as demonstrações de uma preferência que não existia.

As intenções de Rosina, leitor curioso, eram perfeitamente conjugais. Queria casar, e casar o melhor que pudesse. Para este fim aceitava a homenagem de todos os seus pretendentes, escolhendo lá consigo o que melhor correspondesse aos seus desejos, mas ainda assim sem desanimar os outros, porque o melhor deles podia falhar, e havia para ela uma coisa pior que casar mal, que era não casar absolutamente.

Este era o programa da moça. Junte a isso que era naturalmente loureira, que gostava de trazer ao pé de si uma chusma de pretendentes, muitos dos quais é preciso saber que não pretendiam casar, e namoravam por passatempo, o que revelava da parte desses cavalheiros uma incurável vadiação de espírito.

${ }^{38} \mathrm{JF}$ compungindo 
Quem não tem cão, caça com o gato, diz o provérbio. Ernesto era pois, moral e conjugalmente falando, o gato possível de Rosina, uma espécie de pis-aller, - como dizem os franceses, - que convinha ter à mão.

O rapaz moço de nariz comprido não pertencia ao número dos namorados de arribação; seus intentos eram estritamente conjugais. Tinha vinte e seis anos, era laborioso, benquisto e, econômico, singelo e sincero, um verdadeiro filho de Minas. Podia fazer a felicidade de uma moça.

A moça, pela sua parte, soubera insinuar-se tanto no espírito do rapaz dele, que por pouco lhe fez perder o emprego. Um dia, chegando-se o patrão à escrivaninha ${ }^{39}$ em que ele trabalhava, viu um papelinho debaixo do tinteiro, e leu a palavra amor, duas ou três vezes repetida. Uma que fosse bastava para fazê-lo subir às nuvens. O Sr. Gomes Arruda contraiu as sobrancelhas, concentrou as ideias, e improvisou uma alocução extensa e ameaçadora, em que o mísero guarda-livros só percebeu a expressão olho da rua.

Olho da rua é uma expressão grave. Luís Pereira $\mathrm{O}$ guarda-livros meditou nela, reconheceu a justiça do patrão, e tratou de emendar-se dos descuidos, não do amor. §O amor ia-se enraizando nele cada vez mais; era a primeira paixão séria que o rapaz sentia, e acrescendo que ele acertara logo de dar com uma mestra no ofício.

- Isto assim não pode continuar, pensava o rapaz de nariz comprido, coçando o queixo e caminhando uma noite para casa, o melhor é casar-me logo de uma vez. Com o que me dão lá em casa e o produto de alguma escrita por fora, creio que poderei ocorrer às despesas; o resto pertence a Deus.

Não tardou que Ernesto desconfiasse das intenções do rapaz de nariz comprido. Uma vez chegou a surpreender um olhar da moça e do rival. Irritou-se Enfadou-se, e na primeira ocasião que teve interpelou a namorada a respeito daquela circunstância equívoca.

- Confesse! dizia ele.

- Oh! meu Deus! exclamou a moça; você de tudo desconfia. Olhei para ele, sim, é verdade, mas olhei por sua casaca causa.

- Por minha causa? perguntou Ernesto com um tom gelado de ironia.

- Sim, examinava-lhe a gravata, que é muito bonita, para dar uma a você no dia de ano bom Ano Bom. Agora que me obrigou a descobrir tudo, veja se me lembra outro mimo, porque esse já não serve.

\footnotetext{
${ }^{39} J F$ escriventinha
} 
Ernesto caiu em si; recordou-se que efetivamente havia no olhar da moça uma tal ou qual intenção dadival, se me permitem este adjetivo obsoleto; toda a sua cólera converteu-se num sorriso amável e contrito, e o arrufo não foi adiante.

Dias depois, era um domingo, estando ele e ela na sala, e um filho de Vieira à janela, foram os dois namorados interrompidos pelo pequeno que descera da cadeira a que trepara, gritando:

- Aí vem ele! aí vem o namorado ele!

- Ele quem? disse Ernesto sentindo esmigalhar-se-lhe o coração.

Chegou à janela: era o rival.

Entrou a tempo na sala Apareceu a tempo a tia de Rosina; uma tempestade iminente já pairava na fronte afogueada de Ernesto.

Entrou pouco depois Pouco depois entrou na sala o rapaz de nariz comprido, que, ao ver Ernesto, pareceu sorrir maliciosamente. Ernesto encordoou. Seus olhares, se fossem punhais, tinham teriam cometido dois assassinatos naquele instante. Conteve-se, porém; , para melhor observar os dois. Rosina não parecia prestar ao outro atenção de caráter especial; tratava-o com polidez apenas. Isto acalmou aquietou um pouco o ânimo revolto do Ernesto, que ao cabo de uma hora estava restituído à sua usual bem-aventurança.

Não reparou porém nos olhares desconfiados que o rapaz de nariz comprido the lançava de quando em quando. O sorriso malicioso desaparecera dos lábios do guarda-livros. A suspeita entrara-lhe no espírito ao ver a maneira indiferente, ou quase, com que o tratava Rosina, posto tratasse de igual modo ao outro pretendente.

- Será seriamente um rival? pensava o rapaz de nariz comprido.

Na primeira ocasião em que pôde trocar duas palavras com a namorada, sem testemunhas, o que foi logo no dia seguinte, manifestou a desconfiança que lhe escurecera o espírito até ali tão cor-de-rosa. § Rosina soltou uma risada, - uma dessas risadas que levam a convicção ao âmago do coração fundo d'alma, - a tal ponto que o rapaz de nariz comprido julgou de sua dignidade não insistir na absurda suspeita.

- Já lho lhe disse; : ele bem vontade tem de que eu o namore, mas perde o tempo: eu só tenho uma cara e um coração.

- Oh! Rosina, tu és um anjo!

- Quem dera!

- Um anjo, sim, insistiu o rapaz de nariz comprido; e creio que posso chamar-te brevemente minha esposa.

Os olhos da moça faiscaram de contentamento.

— Sim, continuou o namorado; daqui a dois meses estaremos casados...

- Ah!

- Se todavia... 


\section{Rosina empalideceu.}

- Todavia? repetiu ela.

- Se todavia, o Sr. sr. Vieira consentir...

- Por que não, disse a moça buscando tranquilizar-se tranquilizando-se do susto que tivera; ele deseja a minha felicidade; e o casamento contigo é a minha felicidade maior. Ainda quando porém se oponha aos impulsos do meu coração, basta que eu queira para que os menos nossos desejos se realizem. Mas descansa; meu tio não porá obstáculos.

O rapaz de nariz comprido ficou ainda a olhar para a moça alguns minutos sem dizer palavra; admirava duas coisas: a força d'alma de Rosina e o amor que ela lhe dedicava. §Quem rompeu o silêncio foi ela.

- Mas então daqui a dois meses? disse.

- Só se a sorte me for adversa.

- E poderá sê-lo?

— Quem sabe? respondeu o rapaz de nariz comprido com um suspiro de dúvida.

Também coube a Ernesto o ensejo de insinuar alguma coisa a respeito do rival.

- Nova desconfiança? disse impetuosamente Rosina.

- Não, acudio Ernesto; desta vez não é desconfiança.A princípio confesso que desconfiei; nem era para menos ; o dito do Juquinha (era o nome do filho de Vieira) era de por a pulga atrás da orelha a quem já tinha tido algumas dúvidas... Mas quando eu vi a maneira por que você o tratou, fiquei tranquilo. Mais ainda; fiquei alegre. O pobre pretendente estava com uma cara de palmo e meio. Mas deixe estar, quem o ensina sou eu.

- Que mal lhe fez ele?

- Ah! defende-o!

- Eu? Que tolice! Pergunto-lhe só que mal lhe fez ele.

-É pouco?

- Deixe-se disso, Ernesto; seja homem! Eu não sei se ele tem pretensões. Se as tem perde o tempo comigo. Confie em mim e deixe lá os outros. Não é crime gostar de mim, creio eu...

- Crime não é, respondeu Ernesto, mas é desaforo; e eu não permito...

- Ah! se você fosse a castigar quantos gostam de mim!

Ernesto ficou roxo.

- O essencial, continuou a moça, é que eu não lhes preste atenção; e isso...

Ernesto reconheceu a evidência desta argumentação, pediu desculpa a Rosina e prometeu rir-se do rival. Notou entretanto daí a dias que as cartas da moça começavam a escassear. Rosina dava ora uma razão, ora outra; mas o certo é que não respondia, ou respondia raras vezes às missivas do rapaz.

Por quê?

Esta pergunta foi o ponto de partida de uma série de conjecturas, todas tétricas, e algumas ensanguentadas. Ernesto passeou cerca de uma hora na sala da casa em que morava fazendo a si mesmo uma enfiada de perguntas que pareciam não acabar nunca mais.

Ama a outro?

Esfria comigo?

Que será o outro?

Será ele?

Ou terceiro?

Ou quarto? 
"Ernesto de tal"

Devo matá-lo?

Devo desprezá-lo?

Ou simplesmente expulsá-lo?

Não conseguiu adotar nenhuma destas resoluções, nem acertou com qual das perguntas exprimia a realidade da situação.

Jorge, seu companheiro de casa, chegou a tempo de lhe dar dois conselhos. Ele precisava de um; tinha dois à escolha.

Logo depois desta perspectiva de felicidade, a concha em que se pesavam as esperanças de Ernesto começou a subir um pouco. Ele via que Rosina efetivamente parecia ir diminuindo as cartas, e nas poucas que já então recebia dela, a paixão era menos intensa, a frase estudada, acanhada e fria. Quando estavam juntos havia menos intimidade expansiva; a presença dele parecia constrangê-la. Ernesto entrou seriamente a crer que a batalha estava perdida.

Infelizmente a tática deste namorado, era perguntar à própria moça se eram fundadas as suspeitas dele, ao que ela respondia vivamente que não, e isto bastava a restituir-lhe a paz do espírito. Não era longa nem profunda a quietação; o laconismo epistolar de Rosina, a frieza de seus modos, a presença do outro, tudo isso sombreava singularmente o espírito de Ernesto. Mas tão depressa caía no abismo do desespero, como ascendia às regiões da celeste bem-aventurança, mostrando assim o que a natureza queria que ele fosse, - alma inconsistente e passiva - levada, como a folha, ao sabor de todos os ventos.

Entretanto, era difícil que a verdade não se the metesse pelos olhos. Um dia reparou que, além da suspeitosa afetuosidade de Rosina, havia da parte do tio certas atenções características para com o rival. Não se enganava; conquanto o novo pretendente ainda não houvesse pedido formalmente a mão da moça, era quase certo para o Sr. Vieira que nele se preparava novo sobrinho, e acertando de ser este um homem do comércio, não podia haver, na opinião do tio, mais feliz escolha.

Desisto de pintar os desesperos, os terrores, as imprecações de Ernesto no dia em que a certeza da derrota mais funda e de raiz se lhe cravou no coração. Já então não lhe bastou a negativa de Rosina, que aliás lhe pareceu frouxa, e efetivamente o era. O triste moço chegou a desconfiar que a amada e o rival estariam de acordo para mofar dele.

Como por via de regra, é da nossa miserável condição que o amor-próprio domine o simples amor, apenas aquela suspeita lhe pareceu provável, apoderou-se dele uma feroz indignação, e duvido que nenhum quinto ato de melodrama ostente maior soma de sangue derramado do que ele verteu na fantasia. Na fantasia, apenas, compassiva leitora, não só porque ele era incapaz de fazer mal a um seu semelhante, mas sobretudo porque repugnava à sua natureza achar uma resolução qualquer. Por esse motivo, depois de muito e longo cogitar, confiou todos os seus pesares e suspeitas ao companheiro de casa e pediu-lhe um conselho; Jorge 
deu-lhe dois.

- Minha opinião, disse Jorge, é que não te importes com ela e vás trabalhar, que é coisa mais séria.

- Nunca!

- Nunca trabalhar?

- Não; nunca esquecê-la.

- Bem, disse Jorge descalçando a bota do pé esquerdo, nesse caso vai ter com esse sujeito de quem desconfias e entende-te com ele.

- Aceito! exclamou Ernesto; é o melhor. Mas, continuou ele depois de refletir um instante, e se ele não for meu rival, que hei de fazer? como descobrir se há outro?

- Nesse caso, disse Jorge estendendo-se filosoficamente na marquesa, nesse caso o meu conselho é que tu, ele e ela vão todos para o diabo que os carregue.

Ernesto cerrou os ouvidos à blasfêmia, vestiu-se e saiu

A ideia de Ernesto era ir rondar à porta da casa em que trabalhava o rapaz de nariz comprido, esperar que ele saísse, aproximar-se casualmente dele, e entabolar a conversa.

Eram quatro horas da tarde.

Em caminho foi Ernesto refletindo na situação em que se achava; era-lhe impossível continuar assim; uma vez casado, cessava tudo. Meios não tinha, mas a ocasião era de sacrifício e esforço; cumpria sair da dificuldade o mais cedo que pudesse.

- Sim, dizia ele, isto deve acabar de uma vez. Dentro de quatro meses estou casado, custe o que custar.

De repente porém veio-lhe à ideia o rival.

- Contanto que ele não esteja já a empatar-me as vasas, porque nesse caso...

Um gesto terrível completou esta frase que os não tiveram ânimo de concluir.

Pouco tempo depois saía de casa o rapaz de nariz comprido. Ernesto aproximou-se casualmente dele. Cumprimentaram-se com um sorriso que parecia uma careta, e ficaram alguns minutos a olhar um para o outro sem saber como sair da dificuldade. Já o guarda-livros ia tirando o chapéu e despedindo-se, quando Ernesto lhe perguntou sorrindo:

Apenas saiu à rua, embicou Ernesto para a casa em que trabalhava o rapaz de nariz comprido, resolvido a explicar-se de uma vez com ele. Hesitou alguma coisa, é verdade, e esteve a pique de arrepiar carreira; mas a crise era tão violenta que triunfou da frouxidão de ânimo, e vinte minutos depois chegava ele ao seu destino. Não entrou no escritório do rival: pôs-se a passear de um lado para outro, à espera que ele saísse, o que se verificou daí a três quartos de hora, três enfadonhos e mortais quartos de hora.

Ernesto aproximou-se casualmente do rival; cumprimentaram-se com um sorriso acanhado e amarelo, e ficaram alguns segundos a olhar um para o outro. Já o guarda-livros ia tirando o chapéu e despedindo-se, quando Ernesto lhe perguntou:

- Vai hoje à rua do Conde? 
- Talvez.

- A que horas?

- Não sei ainda. Por quê?

- Iríamos juntos. Eu vou às oito.

O rapaz de nariz comprido não respondeu.

- Para que lado vai ? agora? perguntou Ernesto depois de algum silêncio.

- Vou ao Passeio Público, se o senhor não for lá lá não for, respondeu resolutamente o rival.

Ernesto empalideceu.

- Quer assim fugir de mim?

- Sim, senhor.

- Pois eu não; desejo até que haja uma explicação entre nós. Espere... não me volte as costas. Saiba que eu também sou atrevido, menos de língua ainda que de mão. Vamos, dê-me o braço e caminhemos ao Passeio Público.

O rapaz de nariz comprido teve ímpetos de atracar-se com o rival e experimentar-lhe as forças; mas estavam numa rua comercial; todo o seu futuro voaria pelos ares. Preferiu voltar-lhe dar-lhe as costas e seguir caminho. Executava já este plano, quando Ernesto lhe gritou:

- Venha cá, namorado sem-ventura!

Sem-ventura!

O pobre rapaz voltou-se rapidamente.

- Que diz o senhor? perguntou ele.

- Namorado sem-ventura, repetiu Ernesto cravando os olhos no rosto do rival a ver se lhe descobria uma confissão qualquer.

- É singular, replicou o rapaz de nariz comprido, é singular que o senhor me chame namorado sem-ventura, quando ninguém ignora a triste figura que tem feito para obter as boas graças de uma moça que é minha...

- Sua!

- Minha!

- Nossa, direi eu...

- Senhor!

O rapaz de nariz comprido engatilhou um soco; a segurança e tranquilidade com que Ernesto olhava para ele mudaram-lhe o curso das ideias. Podia ser que ele falasse verdade; era melhor saber tudo. Uma exposição franca salvava-os. Pensou nisto algum tempo, e disse, dando o braço a Ernesto:

-Vamos ao Passeio Público.

Em caminho referiram os nossos rivais tudo o que havia entre cada um deles e a moça; a descrição das contrações nervosas que a cara de ambos fazia a cada revelação nova, era digna e própria de um Homero. Ernesto tinha as faces afogueadas; o rapaz de nariz comprido estava pálido.

- Em suma, disse este descendo com o rival pela rua das Marrecas; fomos vilmente enganados.

- Fomos.

- Ambos temos-lhe amor...

- Creio que sim; pela minha parte não amei nunca assim... Que faremos?

- Desprezá-la.

- Não basta, disse Ernesto com resolução; é necessário uma vingança exemplar. Não estou disposto a ser ludibriado por esse modo... 
- Mas repare, disse o rapaz de nariz comprido, que vingança podemos nós tomar dela? Nenhuma. A verdadeira vingança é o desprezo... Ah! Rosina!

Esta exclamação já foi soltada no Passeio; só o guarda a ouviu. Os dois rivais amigos caminharam longo tempo a falar de si e dela; cada um deles tinha casualmente uma carta da namorada no bolso. Foram ambas lidas, e averiguada mais uma vez a perfídia da moça, que respondia aos dois com expressões de ternura e apaixonado amor.

Depois de uma hora de confissões mútuas e projetos de vingança, concordaram os dois rivais amigos que a melhor desforra que podiam tomar dela, era mandar-lhe cada um deles uma carta de igual teor, declarando-lhe que se recusavam ao casamento e se despediam dela.

Assim se fez. Falaria ele verdade? Essa moça, que tanto amor lhe jurava, com quem meditava casar dentro de pouco tempo, mas de quem alguma vez desconfiara, teria dado efetivamente àquele homem o direito de a chamar sua? Esta simples interrogação perturbou o espírito do rapaz, que esteve cerca de dois minutos a olhar mudamente para Ernesto, e este a olhar mudamente para ele.

- O que o senhor disse agora é muito grave; preciso de uma explicação.

- Peço-lhe explicação igual, respondeu Ernesto.

- Vamos ao Passeio Público.

Seguiram caminho, a princípio silenciosos, não só porque a situação os acanhava naturalmente, mas também porque cada um deles receava ouvir uma cruel revelação. A conversa começou por monossílabos e frases truncadas, mas foi a pouco e pouco fazendo-se natural e correta. Tudo quanto os leitores sabem de um e outro foi ali exposto por ambos, por ambos ouvido entre abatimento e cólera.

- Se tudo quanto o senhor diz é a expressão da verdade, observou o rapaz de nariz comprido descendo a rua das Marrecas, a conclusão é que fomos enganados...

- Vilmente enganados, emendou Ernesto.

- Pela minha parte, tornou o primeiro, recebo com isto um grande golpe porque eu amava-a muito, e pretendia fazê-la minha esposa, o que sucederia breve. A minha boa fortuna fez com que o senhor me avisasse a tempo...

- Talvez me censurem o passo que dei; mas o resultado que vamos colher justifica tudo. Nem por isso creia que padeço menos.. eu amava loucamente aquela moça!

Ernesto proferiu estas palavras tão de dentro, que elas repercutiram no coração do rival, e ambos ficaram algum tempo calados, a devorar consigo a dor e a humilhação. Ernesto rompeu o silêncio soltando um magoadíssimo suspiro, na ocasião em que entravam no Passeio. Só o guarda pôde ouvi-lo; o rapaz de nariz comprido ia revolvendo no espírito uma dúvida.

- Devo eu condenar tão ligeiramente aquela moça? perguntou ele a si mesmo; e não será este sujeito um pretendente vencido que, por semelhante meio, quer obter a minha neutralidade?

O rosto de Ernesto não parecia dar razão à conjectura do rival; todavia, como o lance era grave e cumpria não ir por aparências, o rapaz de nariz comprido abriu de novo o capítulo das revelações, no que foi acompanhado pelo rival. Todas elas 
iam concordando entre si; os incidentes e os gestos que um relembrava, tinham eco na memória do outro. O que porém decidiu tudo foi a apresentação de uma carta que cada um deles tinha casualmente no bolso. O texto de ambas mostrava que eram recentes; a expressão de ternura não era a mesma nas duas epístolas, porque Rosina, como sabemos, ia afrouxando o tom em relação a Ernesto; mas era quanto bastava para dar ao rapaz de nariz comprido o golpe de misericórdia.

- Desprezemo-la, disse este, quando acabou de ler a carta do rival.

- Só isso? perguntou Ernesto; o simples desprezo será bastante?

- Que vingança tiraríamos dela? objetou o rapaz de nariz comprido. Ainda que alguma fosse possível, não seria digna de nós...

Calou-se; mas tocado de uma súbita ideia exclamou:

- Ah! lembra-me um meio.

- Qual?

- Mandemos-lhe uma carta de rompimento, mas uma carta de igual teor.

A ideia sorriu logo ao espírito de Ernesto, que parecia ainda mais humilhado que o outro, e ambos foram dali redigir a carta fatal.

No dia seguinte, logo depois do almoço, estava Rosina em casa muito sossegada e, longe de esperar o golpe; , e até forjando planos de futuro, que por agora tinham base assentavam todos no rapaz de nariz comprido, quando o moleque lhe apareceu com duas cartas.

- Nhanhã Rosina, disse ele baixinho.

- Nhanhã Rosina, disse ele, esta carta é de sinhô Ernesto, e esta...

-Que é?

- Que é isso? disse a moça; os dois...

- Aqui está uma carta de senhô Ernesto, e esta outra ...

- Quê! exclamou a moça; os dois...

- Não, explicou o moleque; um estava na esquina de cima, outro na esquina de baixo. Ó gentes! pois eu não hei de saber como se arranja isto?

E fazendo tinir no bolso alguns cobres que os dois rivais the haviam dado, o moleque deixou a senhora moça ler à vontade as duas missivas. $\S$ A primeira que abriu foi a de Ernesto. § Dizia assim: § "Senhora! § "Hoje que tenho certeza de que a senhora é uma pérfida da sua perfídia, certeza que já nada me pode arrancar do espírito, tomo a liberdade de lhe dizer que está livre e eu reabilitado. §"Basta de humilhações! §"Pude dar-lhe crédito enquanto lhe era possível enganar-me. §"Agora... §"Adeus para sempre!"

Rosina levantou os ombros ao ler esta carta; e abriu. Abriu rapidamente a do rapaz de nariz comprido. $\S$ E leu:

"Senhora! §"Hoje que tenho certeza de que a senhora é uma périida da sua perfídia, certeza que já nada me pode..."

Daqui para diante foi crescendo a surpresa. Ambos se despediam; ambos por igual teor. Logo, tinham descoberto tudo um ao outro. Não 
havia meio de reparar nada; tudo estava perdido!

Rosina não costumava ${ }^{40}$ chorar. Esfregava às vezes os olhos ${ }^{41}$, para os fazer vermelhos, quando havia necessidade de mostrar a um namorado que se ressentia de alguma coisa. Desta vez porém chorou deveras; não de mágoa, mas de raiva. Triunfavam ambos os rivais; ambos lhe fugiam, e lhe davam de comum acordo o último golpe. Não havia resistir; entrou-lhe na alma o desespero. Por desgraça não havia no horizonte a mais ligeira vela. O primo a quem aludimos num dos capítulos anteriores, andava com ideias a respeito de outra moça, e ideias já conjugais. Ela mesma descuidara o seu sistema durante os últimos trinta dias deixando sem resposta alguns olhares interrogadores. Estava pois abandonada de Deus e dos homens.

Não; ainda lhe restava um recurso.

VI

Um mês depois daquele fatal desastre, estando Ernesto em casa a conversar com o companheiro e mais dois amigos, um dos quais era o rapaz de nariz comprido, ouviu bater palmas. Foi à escada; era o moleque da rua Nova do Conde.

- Que me queres? disse ele com ar severo porque suspeitava, suspeitando que o moleque viesse pedir-lhe dinheiro.

- Venho trazer isto, disse o moleque baixinho.

E tirou do bolso uma carta que entregou a Ernesto.

A primeira ideia de Ernesto foi recusar a carta e pôr o moleque a pontapés pela escada abaixo; mas o coração disse-lhe uma coisa, como ele mesmo confessou depois. Estendeu a mão, recebeu a carta, abriu-a e leu-a leu.

Dizia assim:

"Ainda uma vez curvo-me às tuas injustiças. Estou cansada de chorar. Não posso mais viver debaixo da ação de uma calúnia. Vem ou eu morro!"

Ernesto esfregou os olhos; não podia crer no que acabava de ler. Seria um novo ardil, ou a expressão da verdade? Ardil podia ser; mas Ernesto atentou bem e pareceu-lhe ver o sinal de uma lágrima. Evidentemente a moça chorara. Mas se chorara é porque sofria padecia; e nesse caso...

Nestas e noutras reflexões gastou Ernesto cerca de oito a dez minutos. Não sabia que resolvesse. Acudir ao chamado de Rosina, era esquecer a perfídia com que ela se houve amando a outro em cujas mãos vira até uma carta dela sua. Mas não ir, podia ser contribuir para a morte de uma criatura que, ainda quando não tivesse sido amada por ele, merecia os seus sentimentos de humanidade.

\footnotetext{
${ }^{40} J F$ continuava

${ }^{41} J F$ Empregava às vezes alhos
} 
- Diga que lá irei logo, respondeu enfim Ernesto.

Quando voltou para a sala trazia o rosto mudado. Os amigos repararam na mudança e procuraram descobrir-lhe a causa.

- Algum credor, dizia um.

- Não lhe trouxeram dinheiro, acrescentava outro.

- Namoro novo, opinava o companheiro de casa.

- É tudo isso talvez, respondeu Ernesto com um modo que queria ser alegre.

De tarde preparou-se Ernesto e deitou a andar dirigiu-se para a rua Nova do Conde. Dez ou doze vezes parou resolvido a voltar; mas um minuto de reflexão, tirava-lhe os escrúpulos e o rapaz prosseguia em seu caminho.

- Há mistério nisto tudo, dizia ele consigo e relendo a carta de Rosina. É certo que ele me revelou tudo, e até me leu cartas; nisto não há que duvidar. Rosina é culpada; enganou-me; namorava a outro, dizendo-me que só me amava a mim? . Mas por que esta carta? Se ela amava ao outro por que lhe não escreve? Investiguemos tudo isto.

A última hesitação do pobre digno rapaz foi ao entrar na rua Nova do Conde; seu espírito vacilou dessa vez mais que nunca. Dez minutos gastou em passinhos ora para trás, ora para diante, sem assentar numa coisa definitiva. Afinal deitou o coração à larga e seguiu afoitamente a senda que o destino parecia indicar-lhe.

Quando chegou à casa de Vieira, estava Rosina na sala com a tia; Ernesto entrou com uma cara que eu não desejo a nenhum dos leitores. A moça teve um movimento de alegria; mas, tanto quanto Ernesto pôde examinar-lhe as feições, a alegria não foi tal que pudesse disfarçar-lhe os sulcos das lágrimas. O que é certo é que um véu de melancolia parecia envolver os olhos travessos da bela Rosina. Nem já eram travessos; estavam desmaiados ou mortos.

- Oh! ali está a inocência! disse Ernesto consigo.

Ao mesmo tempo, envergonhado por esta opinião tão benevolente, e lembrando-se das revelações do rapaz de nariz comprido, Ernesto assumiu um ar severo e grave, menos de namorado que de juiz, menos de juiz, que de algoz.

Rosina cravou os olhos no chão.

A tia da moça perguntou a Ernesto as causas da sua ausência tão prolongada ${ }^{42}$. Ernesto alegou muito trabalho e alguma doença, as primeiras desculpas que ocorrem a todo o homem que não tem desculpa. Trocadas mais algumas palavras, saiu a tia da sala para ir dar umas ordens, tendo chamado prévia e já ordenado disfarçadamente o ao Juquinha para ficar que ficasse na sala. Juquinha porém trepou numa a uma cadeira e pôs-se à janela; os dois

${ }^{42} H M N$ prslongada 
tiveram tempo para explicações.

A situação era esquerda; mas não se podia perder tempo. Bem o compreendeu Rosina, que rompeu logo estas palavras:

- Não tem remorsos?

— De quê? perguntou Ernesto espantado.

- Do que me fez?

$-\mathrm{Eu}$ ?

- Sim, abandonando-me sem uma explicação. A causa adivinho eu qual é; alguma nova suspeita, ou antes alguma calúnia...

- Nem calúnia, nem suspeita, disse Ernesto depois de um momento de silêncio; mas só verdade.

Rosina sufocou um grito; seus lábios pálidos e trêmulos quiseram murmurar alguma coisa, mas não puderam; dos olhos rebentaram-lhe duas grossas lágrimas. § Ernesto não podia vê-la chorar; por mais cheio de razões que estivesse, em vendo lágrimas, curvava-se logo e pedia-lhe perdão. Desta vez porém era impossível que tão depressa voltasse ao antigo estado. As revelações do rival estavam ainda frescas na memória.

Curvou-se, entretanto, para a moça e pediu-lhe que não chorasse.

- Que não chore! disse ela com voz lacrimosa. Pede-me que não chore quando eu vejo fugir-me a felicidade das mãos, sem ao menos merecer a sua estima, porque o senhor despreza-me; sem ao menos saber o que é essa calúnia para desmenti-la ou desmascará-la...

-É capaz disso? perguntou Ernesto com fogo. É capaz de confundir a calúnia?

- Sou, disse ela com um magnífico gesto de dignidade.

Ernesto expôs em resumo a conversa que tivera com o rapaz de nariz comprido, e concluiu dizendo que vira uma carta dela. Rosina ouviu calada a narração; tinha o peito ofegante; sentia-se a comoção que a dominava. Quando ele acabou, soltou uma torrente de lágrimas.

- Meu Deus! disse baixinho Ernesto, podem ouvi-la.

- Não importa, exclamou a moça; estou disposta a tudo...

- Diga-me, pode negar o que lhe acabo de contar?

— Tudo, não; alguma coisa é verdade, respondeu ela com voz triste.

- Ah!

- A promessa de casamento é mentira; não houve mais que duas cartas, duas apenas, e isso... por sua culpa...

- Por minha culpa! exclamou Ernesto tão assombrado como se acabasse de ver um dos castiçais a dançar.

— Sim, repetiu ela, por sua culpa. Não se lembra? Tinha-se arrufado uma vez comigo, e eu... foi uma loucura... para metê-lo em brios, para vingar-me... que loucura!... correspondi ao namoro daquele indivíduo sem 
educação... foi demência minha, bem vejo... Mas que quer? eu estava despeitada...

- Oh! basta! basta! disse Ernesto compreendendo tudo e caindo em si. Vejo tudo claro; a culpa foi minha; eu só fui culpado; perdôo-te a leviandade; não! não! tu és que me deves perdoar...

E foi por este teor fazendo um longo discurso de contrição, interrompido infelizmente pela tia de Rosina.

As pazes estavam feitas.

É inútil dizer que Ernesto não pôde olhar para o rapaz de nariz comprido sem um ar de desprezo misturado de comiseração. Não brigaram todavia; pelo contrário, dois anos depois, estando já Ernesto casado com Rosina, encontramos os dois rivais associados num armarinho. Dão-se perfeitamente. O rapaz de nariz comprido é padrinho de um filho de Ernesto.

A alma de Ernesto ficou fortemente abalada com esta exposição que a moça Ihe fazia dos acontecimentos. Era claro para ele que Rosina negaria tudo, se o seu procedimento tivesse alguma intenção má; a carta, diria que era imitação da sua letra. Mas não; ela confessava tudo com a mais nobre e rude singeleza deste mundo; somente, - e nisto estava a chave da situação, - a moça explicava a que impulsos de despeito cedera, mostrando assim, se podemos comparar o coração a um pastel, debaixo do invólucro da leviandade a nata do amor.

Decorreram alguns segundos de silêncio, em que a moça tinha os olhos pregados no chão, na mais triste e melancólica atitude que jamais teve uma donzela arrependida.

- Mas não viu que esse ato de loucura podia causar a minha morte? disse Ernesto.

Rosina estremeceu ouvindo estas palavras que Ernesto lhe disse com a voz mais doce dos seus antigos dias; levantou os olhos para ele e tornou a pousá-los no chão.

- Se eu tivesse refletido nisso, observou ${ }^{43}$ ela, não faria nada do que fiz.

- Tem razão, ia dizendo Ernesto, mas levado de um mau espírito de vingança entendeu que a leviandade da moça devia ser punida com alguns minutos mais de dúvida e recriminação.

A moça ouviu ainda muitas coisas que the disse Ernesto, e a todas respondeu com um ar tão contrito e palavras tão repassadas de amargura, que o nosso namorado sentiu quase rebentarem-lhe as ${ }^{44}$ lágrimas dos olhos. Os de Rosina estavam já mais tranquilos, e a limpidez começava a tomar o lugar da sombra melancólica. A situação era quase a mesma de algumas semanas antes; faltava só consolidá-la com o tempo. Entretanto, disse Rosina:

- Não pense que lhe peço mais do que me cumpre. Meu procedimento alguma punição há de ter, e eu estou perfeitamente resignada. Pedi-lhe que viesse aqui ${ }^{45}$ a fim de me explicar o seu silêncio; pela minha parte expliquei-lhe o meu desvario. Não posso ambicionar mais...

\footnotetext{
${ }^{43} H M N$ observar

${ }^{44} \mathrm{HMN}$ os lágrimas

${ }^{45} \mathrm{HMN}$ de a fim
} 
- Não pode?...

- Não. Meu fim era não desmerecer a sua estima.

- E por que não o meu amor? perguntou Ernesto. Parece-lhe que o coração possa apagar de repente, e por simples esforço de vontade, a chama de que viveu longos dias?

- Oh! isso é impossível! respondeu a moça; e pela minha parte sei o que vou padecer...

- Demais, disse Ernesto, a culpa de tudo fui eu, francamente o confesso. Ambos nós temos que perdoar um ao ${ }^{46}$ outro; perdoo-lhe a leviandade; perdoa-me o fatal arrufo?

Rosina, a menos de ter um coração de bronze, não podia deixar de conceder o perdão que o namorado the pedia. Foi recíproca a generosidade. Como na volta do filho pródigo, as duas almas festejaram aquela renascença de felicidade, e amaram-se com mais força que nunca.

Três meses depois, dia por dia, foi celebrado na igreja de S. Ana, que era então no Campo d'Aclamação, o consórcio dos dois namorados. A noiva estava radiante de ventura; o noivo parecia respirar os ares do paraíso celeste. O tio de Rosina deu um sarau a que compareceram os amigos de Ernesto, exceto o rapaz de nariz comprido.

Não quer isto dizer que a amizade dos dois viesse a esfriar. Pelo contrário, o rival de Ernesto revelou certa magnanimidade ${ }^{47}$, apertando ainda mais os laços que o prendiam desde a singular circunstância que os aproximou. Houve mais; dois anos depois do casamento de Ernesto, vemos os dois associados num armarinho, reinando entre ambos a mais serena intimidade. O rapaz de nariz comprido é padrinho de um filho de Ernesto.

- Por que não te casas? pergunta Ernesto às vezes ao seu sócio, amigo e compadre.

- Nada, meu amigo, responde o rapaz de nariz comprido; outro, eu já agora morro solteiro.

\section{4 "Aurora sem dia"}

\section{Aurora sem dia}

Naquele tempo contava Luís Tinoco vinte e um anos. Era um rapaz de estatura meã, olhos vivos, cabelos em desordem, língua inesgotável e paixões impetuosas. Exercia um modesto emprego no foro, donde tirava

\footnotetext{
${ }^{46} \mathrm{HMN}$ a outro

${ }^{47} H M N$ nagnanimidade
} 
o parco sustento, e morava na Cidade Nova com um tio velho, com o padrinho cujos meios de subsistência consistiam no ordenado da sua aposentadoria. Tinoco estimava o tio velho Anastácio e este tinha pelo sobrinho ao afilhado igual afeição. Cada um deles tinha no outro o único parente deste mundo.

Luís Tinoco possuía a convicção de que estava fadado para grandes destinos, e foi esse durante muito tempo o maior obstáculo da sua existência. No tempo em que em que o conheci o Dr. Lemos o conheceu começava a arder-lhe a chama poética. Não sei como lhe se sabe como começou aquilo. Naturalmente os louros alheios entraram a tirar-lhe o sono. Casimiro de Abreu publicara o seu volume tão merecidamente aplaudido por todos. Uma plêiade de rapazes cultivava as musas com entusiasmo, e a casa de Paula de Brito era, o centro aonde iam ter todas as vocações imberbes. O folhetim literário e elegante ainda estava vivo, e o teatro representava de quando em quando alguma comédia nacional. § Influía tudo isto naturalmente, no ânimo de Luís Tinoco. Uma bela manhã acordou o nosso rapaz poeta e escritor; $\mathrm{O}$ certo é que um dia de manhã acordou Luís Tinoco escritor e poeta; a inspiração, flor abotoada ainda na véspera, amanheceu pomposa e viçosa. O rapaz atirou-se ao papel com ardor e perseverança, e entre as seis horas e as nove, quando o foram chamar para almoçar tinha ele, tinha produzido um soneto, cujo principal defeito era, ter cinco versos com sílabas de mais e outros cinco com sílabas de menos. Tinoco levou a produção ao Correio Mercantil, que a publicou entre os, a pedidos a-pedidos.

As pessoas que conhecem este ofício de pena, e que têm passado a sua vida a gastar algumas resmas de papel, sabem com que prazer se leem impressas as primeiras produções. Nenhuma mãe contempla o filho recém-nascido com mais amor, do que um poeta estreante lê e relê a primeira produção impressa. Assegura-se logo que todos os leitores do jornal estão fazendo o mesmo, e que o nome do jovem autor anda na boca de todos como uma grande revelação literária. Falo daqueles que começam lentamente os seus primeiros passos, como Corneille, que antes de chegar ao Cid, fez tanta coisa que jaz nos limbos do esquecimento, e Bocage, que começou pelo soneto de procissão de S. Francisco antes de chegar à Saudade Materna, e à Pena de Talião.

Mal dormida, entremeada de sonhos interruptos, de sobressaltos e ânsias, foi a noite que precedeu a publicação. A aurora raiou enfim, e Luís Tinoco, apesar de pouco madrugador, levantou-se com o sol e foi ler o soneto impresso. Nenhuma mãe contemplou o filho recém-nascido com mais amor do que o rapaz leu e releu a produção poética, aliás decorada desde a véspera. Afigurou-se-lhe que todos os leitores do Correio Mercantil estavam fazendo o mesmo; e que cada um admirava a recente revelação literária, indagando de quem seria esse nome até então desconhecido.

Tinoco leu os seus versos impressos, e imaginou desde logo que as letras acabavam de ganhar um florão esplêndido. Não dormiu sobre os louros imaginários. Nova lucubração, e dessa Daí a dois dias, nova composição, e desta vez saiu uma longa ode sentimental, em que o poeta se queixava à lua do desprezo em que o deixara a amada, e já entrevia no futuro a morte melancólica de Gilbert. A nova produção não foi logo publicada porque era longa, mas ao cabo de cinco dias, quando Tinoco já acusava de inveja os redatores 
do Correio Mercantil, a poesia saiu nas colunas daquele jornal com a assinatura do poeta; foi tamanha a alegria de Luís Tinoco que o foi logo contar ao tio. Não podendo fazer despesas, alcançou, por intermédio de um amigo, que a poesia fosse impressa de graça, motivo este que retardou a publicação por alguns dias. Luís Tinoco tragou a custo a demora, e não sei se chegou a suspeitar de inveja os redatores do Correio Mercantil. A poesia saiu enfim; e tal contentamento produziu no poeta que foi logo fazer ao padrinho a grande revelação.

— Leu hoje o Correio Mercantil, tio Anastácio meu padrinho? perguntou ele.

- Rapaz Homem, tu sabes que eu só lia os jornais no tempo em que era empregado efetivo, a fim de dizer ao oficial-maior da secretaria que a oposição não tinha pinga de juízo, e que o governo atual era o melhor de todos os governos. Desde que me aposentei não li mais os periódicos...

- Pois é pena! disse Tinoco com ar frio; queria que me dissesse o que pensa de uns versos que lá vêm.

— E de mais a mais versos! Os periódicos jornais já não falam de política? No meu tempo não falavam de outra coisa.

- Falam de política e publicam versos, porque ambas as coisas têm entrada na imprensa. Quer ler os tais versos?

- Dá cá se o tens.

- Aqui estão.

Tinoco $\mathrm{O}$ poeta puxou da algibeira o Correio Mercantil, e o tio velho Anastácio entrou a ler para si a obra do sobrinho afilhado. Com os olhos pregados no tio padrinho, Luís Tinoco parecia querer adivinhar as impressões que produziam nele os seus elevados conceitos, metrificados com todas as liberdades possíveis e impossíveis do consoante. § Anastácio acabou de ler os versos e fez com a boca um gesto de enfado.

- Isto não tem graça, disse ele ao sobrinho afilhado estupefato; que diabo tem a lua com a indiferença dessa moça, e a que vem aqui a morte deste estrangeiro?

Luís Tinoco teve vontade de descompor o tio padrinho, mas limitou-se a atirar os cabelos para trás e a dizer com supremo ${ }^{48}$ desdém: são meus.

- São coisas de poesia que nem todos entendem; esses versos sem graça,

— Teus? perguntou Anastácio no cúmulo do espanto.

- Sim, senhor.

- Pois tu fazes versos?

- Assim dizem.

- Mas quem te ensinou a fazer versos?

— Isto não se aprende; traz-se do berço.

${ }^{48}$ HMN suprsmo 
Anastácio leu outra vez os versos, e só então reparou na assinatura do sobrinho afilhado. Não havia que duvidar: o rapaz dera em poeta. § Para o velho empregado aposentado era isto uma grande desgraça. Esse, ligava à ideia de poeta a ideia de mendicidade. Tinham-lhe pintado Camões e Bocage, que eram os nomes literários que ele conhecia, como dois improvisadores de esquina, espeitorando sonetos em troca de algumas moedas, dormindo nos adros das igrejas e comendo nas cocheiras das casas-grandes. § Quando soube que o seu querido Luís estava atacado da terrível moléstia, Anastácio entristeceu ficou triste, e foi nessa ocasião que se encontrou comigo, e me deu parte com o Dr. Lemos e Ihe deu notícia da gravíssima moléstia do sobrinho situação do afilhado.

- Dou-lhe parte de que o Luís está poeta.

— Sim? perguntei-lhe eu perguntou-lhe o Dr. Lemos. E que tal lhe saiu o poeta?

- Importa-me cá saber que tal me saiu Não me importa se saiu mau ou bom. O que sei é que é a maior desgraça que lhe podia acontecer, porque isto de poetas poesia não dão dá nada de si. Tenho medo que deixe o emprego, e fique aí pelas esquinas a falar à lua, cercado de moleques.

Tranquilizei O Dr. Lemos tranquilizou o homem dizendo-lhe que os poetas , hoje, não eram esses peripatéticos que ele supunha; mostrei-lhe vadios que ele imaginava; mostrou-lhe que a poesia não era obstáculo para andar como os outros, para ser deputado, ministro ou diplomata.

- No entanto, disse eu o Dr. Lemos, desejarei falar ao Luís; quero ver o que ele tem feito, porque como eu também fui outrora um pouco versejador, posso já saber se o rapaz dá de si.

Luís Tinoco veio ter comigo; trouxe-me foi ter com ele; levou-lhe o soneto e a ode impressos, e mais algumas produções não publicadas. Estas orçavam pela ode ou pelo soneto. Imagens safadas, expressões comuns, dureza de rima; mas frouxo alento e nenhuma arte; apesar de tudo isso, havia de quando em quando algum bosquejo lampejo que indicava da parte do neófito propensão para o mister; podia ser ao cabo de algum tempo um excelente trovador de salas.

Disse-lhe com franqueza $\mathrm{O} \mathrm{Dr}$. Lemos disse-lhe com franqueza, que a poesia era uma arte difícil e que pedia longo estudo, ; mas que, se ele queria a querer cultivá-la a todo o transe, eu lhe daria devia ouvir alguns conselhos necessários.

- Sim, respondeu ele, pode lembrar alguma coisa; eu não me nego a aceitar-lhe o que me parecer bom, tanto mais que eu fiz estes versos muito à pressa e não tive ocasião de os emendar.

Tive vontade de lhe responder mais duramente; mas o rapaz falava de boa fé.

— Não me parecem bons estes versos, disse-lhe eu disse o Dr. Lemos; poderia rasgá-los e estudar antes algum tempo.

Tenho pena de não poder Não é possível descrever o gesto de soberbo desdém, 
com que Luís Tinoco me arrancou os versos das mãos e me ao doutor e lhe disse:

- Os seus conselhos valem tanto como a opinião de meu tio padrinho. Poesia não se aprende; traz-se do berço. Eu não dou atenção a invejosos. Se os versos não fossem bons, o Mercantil não mos os publicava.

E saiu.

Daí em diante foi impossível ter-lhe mão. Tinoco entrou a escrever como quem se despedia da vida. Os jornais andaram cheios de produções do rapaz, e no fim de cinco meses era raro passar por uma loja, sem ver no mostrador um prospecto assim concebido: Os jornais andavam cheios de produções suas, umas tristes, outras alegres, não daquela tristeza nem daquela alegria que vem direitamente do coração, mas de uma tristeza que fazia sorrir, e de uma alegria que fazia bocejar. Luís Tinoco confessava singelamente ao mundo que fora invadido do ceticismo byroniano, que tragara até às fezes a taça do infortúnio, e que para ele a vida tinha escrita na porta a inscrição dantesca. A inscrição era citada com as próprias palavras do poeta, sem que aliás Luís Tinoco o tivesse lido nunca. Ele respingava nas alheias produções uma coleção de alusões e nomes literários, com que fazia as despesas de sua erudição, e não lhe era preciso, por exemplo, ter lido Shakespeare para falar do to be or not to be, do balcão de Julieta e das torturas de Otelo. Tinha a respeito de biografias ilustres noções extremamente singulares. Uma vez, agastando-se com a sua amada — pessoa que ainda não existia, - aconteceu-lhe dizer que o clima fluminense podia produzir monstros daquela espécie, do mesmo modo que o sol italiano dourara os cabelos da menina Aspásia. Lera casualmente alguns dos salmos ${ }^{49}$ do Padre Caldas, e achou-os soporíferos; falava mais benevolamente da Morte de Lindoia, nome que ele dava ao poema de J. Basílio da Gama, de que só conhecia quatro versos.

Ao cabo de cinco meses tinha Luís Tinoco produzido uma quantia razoável de versos, e podia, mediante muitos claros e páginas em branco, dar um volume de cento e oitenta páginas. A ideia de imprimir um livro sorriu-lhe; e daí a pouco era raro passar por uma loja sem ver no mostrador um prospecto assim concebido:

\section{GOIVOS E CAMÉLIAS}

POR

\section{LUÍS TINOCO.}

Um volume de 200 páginas........... 2\$000 rs.

Encontrei-o $\mathrm{O}$ Dr. Lemos encontrou-o algumas vezes na rua. Andava com o ar inspirado de todos os poetas novéis que se supõem apóstolos e mártires.

\footnotetext{
${ }^{49} \mathrm{HMN}$ psalmos
} 
Cabeça alta, olhos vagos, cabelos grandes e caídos; algumas vezes abotoava o paletó e punha a mão ao peito como por ter visto assim um retrato de Guizot; outras vezes andava com as mãos para trás.

Falei-lhe $\mathrm{O}$ Dr. Lemos falou-lhe a terceira vez que o vi viu assim, porque das duas primeiras o rapaz esquivou-se por modo que não pude pôde deter-lhe o passo. Fiz-lhe Fez-lhe alguns elogios às suas produções. Expandiu-se-lhe o rosto e apertou-me entusiasticamente as mão. :

- Obrigado, disse ele; esses elogios são o melhor prêmio das minhas fadigas; $\mathrm{o}$. O povo não está preparado para a poesia. As pessoas inteligentes como o autor: as pessoas inteligentes, como o doutor, podem julgar do merecimento dos outros. Leu a minha Flor pálida?

— Uns versos publicados no domingo?

- Sim.

- Li; são galantíssimos.

— E sentimentais. Fiz aquela poesia em meia hora, e não emendei nada. Acontece-me isso muita vez. Que lhe parecem aqueles esdrúxulos?

- Acho-os esdrúxulos.

- São excelentes. Agora vou levar algumas estrofes que compus ontem. Intitulam-se , À beira de um túmulo.

- Ah!

- Já assinou o meu livro?

- Ainda não.

- Nem assine. Quero dar-lhe um volume. Sai brevemente. Estou recolhendo as assinaturas. Goivos e Camélias; que lhe parece o título?

- Magnífico.

- Achei-o de repente. Lembraram-me outros, mas eram comuns. Goivos e Camélias, parece que é um título distinto e original; é o mesmo que se dissesse: tristezas e alegrias.

- Justamente.

Durante esse tempo, o meu homem tirava ia o poeta tirando do bolso uma aluvião de papéis. Creio que procurava a poesia em questão. Quis esquivar-me Procurava as estrofes de que falara. O Dr. Lemos quis esquivar-se, mas o homem era implacável; segurou-me segurou-lhe no braço. Ameaçado de ouvir ler os versos na rua, convidei o doutor convidou o poeta a jantar ir jantar com ele.

Aceitou com uma alegria de quem tinha fome.

Fomos Foram a um hotel próximo.

- Ah! meu amigo, dizia-me dizia ele em caminho; não imagina quantos invejosos andam a denegrir o meu nome. $\mathrm{O}$ meu talento tem sido o alvo de mil ataques; mas eu já estava disposto a isto. Não me espanto. A enxerga de Camões é um exemplo e uma consolação. Prometeu, atado ao Cáucaso, é o 
emblema do gênio. A posteridade é a vingança dos que sofrem os desdéns do seu tempo.

No hotel procurei procurou o Dr. Lemos um lugar mais afastado, onde não chamássemos chamassem muito a atenção dos outros das outras pessoas.

- Aqui estão as estrofes, disse ele Luís Tinoco conseguindo arrancar de um maço de papéis a poesia anunciada.

- Não lhe parece melhor lê-la lê-las à sobremesa. ?

- Como quiser, respondeu ele; tem razão, porque eu também tenho estou com fome.

Luís Tinoco era todo prosa à mesa do jantar; comeu desencadernadamente.

- Não repare, dizia ele de quando em quando; isto é o animal que se está alimentando. O espírito aqui não tem culpa alguma nenhuma.

À sobremesa, estando na sala apenas uns cinco fregueses, desdobrou Luís Tinoco o papel fatal o fatal papel e leu as anunciadas estrofes, com uma melopeia afetada e perfeitamente ridícula. Os versos falavam de tudo, de morte e de da morte e da vida, das flores e dos vermes, dos amores e dos ódios; havia mais de oito ciprestes, cerca de vinte lágrimas, e mais túmulos do que um verdadeiro cemitério.

Todos os fregueses da sala Os cinco fregueses jantantes voltaram a cabeça para nossa mesa, quando Luís Tinoco começou a recitar os versos; depois começaram a sorrir à socapa, e a murmurar alguma coisa que os dois não pude ouvir puderam ouvir . § Envergonhado com o espetáculo a que me estava dando, ardia eu por ver o fim dos versos, e a cada folha que ele voltava lançava melancólicos olhos para o papel. § Quando o poeta acabou, um dos circunstantes, assaz grosseiro, soltou uma gargalhada: . Luís Tinoco voltou-se enfurecido, mas eu contive-o, o Dr. Lemos conteve-o dizendo:

- Não é conosco.

-É, meu amigo, disse ele resignado; mas que lhe havemos de fazer? quem entende a poesia para a respeitar em toda a parte?

- Deixemos este lugar disse-lhe eu, disse o Dr. Lemos; aqui não compreendem o que é um poeta.

- Apoiado Vamos!

- Paguei O Dr. Lemos pagou a conta e saí saiu atrás de Luís Tinoco, que deitou ao rideiro um olhar de desafio.

Luís Tinoco acompanhou-me acompanhou-o até à casa. Recitou-me Recitou-lhe em caminho alguns versos que sabia de cor. Eu tenho notado que todo o poetastro tem memória prodigiosa. A dele era um monumento. Quando ele se entregava à poesia, não a alheia, que o não preocupava muito, mas a própria, podia-se dizer que tudo mais se the apagava da memória; bastava-lhe a contemplação de si mesmo. O Dr. Lemos ia ouvindo calado com a resignação de quem suporta a chuva, que não pode impedir. 
Pouco tempo depois saíram a lume os Goivos e Camélias, que todos os jornais prometeram analisar mais de espaço.

Dizia o poeta no prólogo da obra, que era audácia da sua parte "vir assentar-se na mesa da comunhão da poesia, mas que todo aquele que sentia dentro de si o ,j'ai quelque chose là, de André Chénier, devia dar à pátria aquilo que a natureza lhe deu". Em seguida pedia desculpa para os seus verdes anos, e afirmava ao público que não tinha sido "embalado em berços de seda". Concluía dando a bênção ao livro e chamando a atenção para a lista dos assinantes que vinha no fim.

Esta obra monumental passou desapercebida despercebida no meio da indiferença geral. Apenas um folhetinista da época, do tempo escreveu a respeito dela algumas linhas que fizeram rir a toda a gente, menos o autor, que foi agradecer ao folhetinista.

Perdi de vista o meu poeta durante alguns meses, mas não lhe aconteceu o mesmo a meu respeito. De quando em quando, recebia alguma produção do homem. Comédias, novelas, poesias, meditações, discursos, tudo escrevia Luís Tinoco com uma atividade pasmosa, e de tudo me mandava um exemplar com a competente dedicatória.

Estava uma vez no teatro assistindo a um espetáculo lírico. Era uma companhia que se achava de passagem para o Rio da Prata. Distribuíram-se versos; eram de Luís Tinoco. Ia a algum enterro; no cemitério saía dentre os convidados o tipo enfadonho do orador fúnebre; era Luís Tinoco. Ficou este rapaz célebre pela sua atividade.

O Dr. Lemos perdeu de vista o seu poeta durante algum tempo. Digo mal; só perdeu de vista o homem, porque o poeta de quando em quando lhe aparecia metido em alguma produção literária, que o Dr. Lemos invariavelmente lia para se benzer da estéril pertinácia de Luís Tinoco. Não havia ocasião, enterro ou espetáculo solene, que escapasse à inspiração do fecundo escritor. Como o número de suas ideias fosse mui limitado, podia-se dizer que ele só havia escrito um necrológio, uma elegia, uma ode ou uma congratulação. Os diferentes exemplares de cada uma destas coisas eram a mesma coisa dita por outro modo. O modo porém constituía a originalidade do poeta, originalidade que ele não teve a princípio, mas que se desenvolveu muito com o tempo.

Ora, ao mesmo tempo que se Infelizmente enquanto se entregava com ardor às lides literárias, esquecia-se o meu homem poeta das lides forenses, donde lhe vinha o pão. Anastácio queixou-se-me queixou-se um dia desta desgraça ao Dr. Lemos, numa carta que acabava assim: "Não sei, meu amigo Sr. Lemos, aonde irá parar este rapaz. Não lhe vejo outra solução conclusão: hospício ou xadrez".

Fui ter com $\mathrm{O}$ Dr. Lemos mandou chamar o poeta. Elogiei-lhe Elogiou-lhe as suas obras para dispor-lhe com o fim de lhe dispor o espírito a ouvir o que eu ia dizer. O rapaz expandiu-se.

- Ainda bem que eu ouço de quando em quando alguma voz animadora, disse ele; não sabe o que tem sido a inveja a meu respeito. Mas que 
importa? Tenho confiança no futuro; o que me vinga é a posteridade.

- Tem razão, a posteridade é que vinga das maroteiras contemporâneas.

— Li há dias num papelucho, que eu era um alinhavador de ninharias. Percebi a intenção. Acusava-me de não meter ombros à a obra de mais largo fôlego. Vou desmentir o papelucho: estou escrevendo um poema épico!

- Ai! disse eu comigo o Dr. Lemos consigo, adivinhando alguma leitura forçada do poema. Felizmente escapei.

- Podia mostrar-lhe alguma coisa, continuou Luís Tinoco, mas prefiro que leia a obra quando estiver completa mais adiantada. Chama-se o poema, Os tupinambás

- Ah! Muito bem.

- Tem dez cantos, cerca de 10:,000 versos. Mas quer saber a minha desgraça?

—Qual é?

- Estou apaixonado...

- Realmente, é uma desgraça na sua posição.

- Que tem a minha posição?

- Creio que não é excelente. Dizem-me que tem descurado um pouco as se tem descuidado um pouco das suas obrigações do foro, e que brevemente lhe vão tirar o emprego.

— Tiraram-mo Fui despedido ontem.

- Já?

- É verdade. Se ouvisse o discurso com que eu respondi ao escrivão, diante de toda a gente que enchia o cartório! Vinguei-me.

- Mas... de que viverá agora? seu tio seu padrinho não pode, creio eu, com o peso da casa.

— Deus me ajudará. Quem sustenta os passarinhos senão ele?

- É verdade, mas os passarinhos não comem bifes nem vestem roupa lavada. Cuido que também não calçam botas de bezerro.

- Compreendo essa prosa da vida; tratarei de arranjar os meios de lhe acudir com os meios. Ah! Rosalina!

- É o nome da sua amada?

- É. Nome lindo, não lhe parece?

- Como a dona.

- Conhece-a?

- Não, mas suponho que para apaixonar um poeta...

— Meu amigo, o senhor é um grande homem. Tem razão; Rosalina é um anjo, e eu adoro-a.

- E ela?

- Ela ignora talvez que me consumo por seu respeito.

- O que é o diabo.

— Que quer? disse Luís Tinoco enxugando com o lenço uma lágrima imaginária; é fado dos poetas arderem por coisas que não podem obter.

Tratei de o aconselhar a que trabalhasse, e ofereci-me para arranjar um emprego condigno com o seu gênio. 
Aceitou o oferecimento.

Tinha um advogado amigo e fui pedir para Luís Tinoco um lugar de escrevente no cartório. Avisei o advogado de que o candidato era poeta, e que cumpria relevar-lhe alguma abstração e até alguma vadiação.

Luís Tinoco foi para casa do advogado.

Esta circunstância que era em si mesma insignificante, produziu uma revolução no espírito do poeta.

Encontramo-nos um dia; perguntei-lhe pelo poema.

- Está parado, disse ele.

- Deixa-o de mão?

- Concluí-lo-ei quando houver tempo. Acabei também com a minha folha.

- Tinha alguma folha?

- Pois não sabia? E diz que aprecia as letras. A minha folha intitulava-se, O canapé literário

- Ah! sei, disse eu fingindo que a conhecia; li-a muitas vezes, mas não sabia que era sua.

- Tinha lá poesias minhas.

— Sim, mas podia ser apenas um colaborador. Ora, muito me conta! Então o Canapé literário acabou?

- Deus me ajudará. Não tenho eu uma pena na mão? Não recebi do berço um tal ou qual engenho, que já tem dado alguma coisa de si? Até agora nenhum lucro tentei tirar das minhas obras; mas era só amador. Daqui em diante o caso muda de figura; é necessário ganhar o pão, ganharei o pão.

A conviç̧ão com que Luís Tinoco dizia estas palavras, entristeceu o amigo do padrinho. O Dr. Lemos contemplou durante alguns segundos - com inveja, talvez, - aquele sonhador incorrigível, tão desapegado da realidade da vida, acreditando não só nos seus grandes destinos, mas também na verossimilhança de fazer da sua pena uma enxada.

- Oh! deixe estar! continuou Luís Tinoco; eu hei de provar-lhes, ao senhor e a meu padrinho, que não sou tão inútil como lhes pareço. Não me falta coragem, doutor; quando me faltasse, há uma estrela...

Luís Tinoco calou-se, retorceu o bigode, e olhou melancolicamente para o céu. O Dr. Lemos também olhou para o céu, mas sem melancolia, e perguntou rindo:

- Uma estrela? Ao meio-dia é raro...

- Oh! não falo dessas, interrompeu Luís Tinoco; lá é que ela devia estar, ali no espaço azul, entre as outras suas irmãs, mais velhas do que ela e menos formosas.

- Uma moça?

- Uma moca, é pouco; diga a mais gentil criatura que o sol ainda alumiou, uma silfide, a minha Beatriz, a minha Julieta, a minha Laura...

- Escusa dizê-lo; deve ser muito formosa se fez apaixonar um poeta.

— Meu amigo, o senhor é um grande homem; Laura é um anjo, e eu adoro-a...

- E ela?

- Ela ignora talvez que eu me consumo.

- Isso é mau!

- Que quer? disse Luís Tinoco enxugando com o lenço uma lágrima imaginária; é fado dos poetas arderem por coisas que não podem obter. É esse o pensamento de uns versos que escrevi há oito dias. Publiquei-os no Caramanchão Literário.

— Que diacho é isso? 
- É a minha folha, que eu the mando de quinze em quinze dias... E diz que lê as minhas obras!

- As obras leio... Agora os títulos, podem escapar. Vamos porém ao que importa. Ninguém lhe contesta talento nem inspiração fecunda; mas o senhor ilude-se pensando que pode viver dos versos e dos artigos literários... Note que os seus versos e os seus artigos são muito superiores ao entendimento popular, e por isso devem ter muito menos aceitação...

Este desenganar com as mãos cheias de rosas, produziu salutar efeito no ânimo de Luís Tinoco; o poeta não pôde sofrear um sorriso de satisfação e bem-aventurança. O amigo do padrinho concluiu o seu discurso oferecendo-lhe um lugar de escrevente em casa de um advogado. Luís Tinoco olhou para ele algum tempo sem dizer palavra. Depois:

- Volto ao foro, não? disse ele com a mais melancólica resignação deste mundo. Minha inspiração deve descer outra vez a empoeirar-se nos libelos, a aturar os rábulas, a engrolar o vocabulário da chicana! E a troco de quê? A troco de uns magros mil-réis, que eu não tenho e me são necessários para viver. Isto é sociedade, doutor?

- Má sociedade, se lhe parece, respondeu o Dr. Lemos com doçura, mas não há outra à mão, e a menos de não estar disposto a reformá-la, não tem outro recurso senão tolerá-la e viver.

O poeta deu alguns passos na sala; no fim de dois minutos estendeu a mão ao amigo.

- Obrigado, disse ele, aceito; vejo que trata de meus interesses, sem desconhecer que me oferece um exílio.

- Um exílio e um ordenado, emendou o Dr. Lemos.

Daí a dias estava o poeta a copiar razões de embargos e de apelação, a lastimar-se, a maldizer da fortuna, sem adivinhar que daquele emprego devia nascer uma mudança nas suas aspirações. O Dr. Lemos não lhe falou durante cinco meses. Um dia encontraram-se na rua. Perguntou-lhe pelo poema.

- Está parado, respondeu Luís Tinoco.

- Deixa-o de mão?

- Concluí-lo-ei quando tiver tempo.

- E a folha?

- Deve saber que acabei com ela; não lha mando há muito tempo.

- É verdade, mas podia ser um esquecimento. Muito me conta! Então acabou o Caramanchão Literário?

— É verdade. Deixei morrer uma folha Deixei-o morrer no melhor período de vitalidade. Tinha trezentos: tinha oitenta assinantes pagantes...

- Mas então abandona as letras?

- Não, mas... Adeus.

- Adeus. 
Pareceu-me simples tudo isto Pareceu simples tudo aquilo; mas tendo-se ganho alguma coisa, que era empregá-lo, deixei o Dr. Lemos deixou que o próprio poeta me viesse the fosse anunciar a causa do seu sono literário. Seria o namoro de Rosalina Laura?

Não tardou que eu achasse a chave deste enigma. O advogado era homem político; o escritório dele era um centro aonde iam ter muitos homens públicos, e onde se conversava largamente dos partidos e do governo.

Esta Laura, preciso é que se diga, não era Laura, era simplesmente Inocência; o poeta chamava-lhe Laura nos seus versos, nome que lhe parecia mais doce, e efetivamente o era. Até que ponto existiu esse namoro, e em que proporções correspondeu a moça à chama do rapaz? A história não conservou muita informação a este respeito. O que se sabe com certeza é que um dia apareceu um rival no horizonte, tão poeta como o padrinho de Luís Tinoco, elemento muito mais conjugal do que o redator do Caramanchão Literário, e que de um só lance Ihe derrubou todas as esperanças.

Não é preciso dizer ao leitor que este acontecimento enriqueceu a literatura com uma extensa e chorosa elegia, em que Luís Tinoco metrificou todas as queixas que pode ter de uma mulher um namorado traído. Esta obra tinha por epígrafe o nessun maggior dolore do poeta florentino. Quando ele a acabou e emendou, releu-a em voz alta, passeando na alcova, deu o último apuro a um ou outro verso, admirou a harmonia de muitos, e singelamente confessou de si para si que era a sua melhor produção. O Caramanchão Literário ainda existia; Luís Tinoco apressou-se a levar o escrito ao prelo, não sem o ler aos seus colaboradores, cuja opinião foi idêntica à dele. Apesar da dor que o devia consumir, o poeta leu as provas com o maior desvelo e escrúpulo, assistiu à impressão dos primeiros exemplares da folha, e durante muitos dias releu os versos até cansar. Do que ele menos se lembrava era da perfídia que os inspirou.

Esta porém não era a razão do sono literário de Luís Tinoco. A razão era puramente política. O advogado, cujo escrevente ele era, tinha sido deputado e colaborava numa gazeta política. O seu escritório era um centro, onde iam ter muitos homens públicos e se conversava largamente dos partidos e do governo. $\S$ Luís Tinoco ouviu a princípio essas conversas com a indiferença de um semi-deus deus envolvido no manto da sua imortalidade. Mas a pouco e pouco foi adquirindo gosto pelo ao que ouvia. Já lia os discursos parlamentares e os discursos políticos artigos de polêmica. Da atenção passou rapidamente ao entusiasmo, porque naquele rapaz tudo era extremo, entusiasmo ou indiferença. Um dia levantou-se com a convicção de que os seus destinos eram políticos.

- A minha carreira literária está feita, disse-me ele, quando falamos disse ele ao

Dr. Lemos quando falaram nisto; agora outro campo me chama.

Procurei dissuadi-lo da ideia, mas foi trabalho inútil. 
- A política? Parece-lhe que é essa a sua vocação?

- Parece-me que posso fazer alguma coisa.

- Vejo que é modesto, e não duvido que alguma voz interior o esteja convidando a queimar as suas asas de poeta. Mas, cuidado! Há de ter lido Macbeth... Cuidado com a voz das feiticeiras, meu amigo. Há no senhor demasiado sentimento, muita suscetibilidade, e não me parece que...

— Estou disposto, respondeu-me, a acudir à voz do meu destino, interrompeu impetuosamente Luís Tinoco A democracia A política chama-me ; corro ao chamado dela ao seu campo; não posso, não devo, não quero cerrar-lhe os ouvidos. Não! as opressões do poder, as baionetas dos governos imorais e corrompidos, não podem desviar uma grande convicção do caminho que ela mesma se traçou escolheu. Sinto que sou chamado pela voz da verdade. Quem foge à voz da verdade? Os cobardes covardes e os ineptos. Não sou inepto nem cobarde covarde.

Tal foi a estreia oratória com que ele me brindou brindou o Dr. Lemos numa esquina onde felizmente não passava ninguém.

- Só lhe peço uma coisa, disse ele o ex-poeta.

- O que é?

- Recomende-me ao doutor. Quero acompanhá-lo, e ser seu protegido; é o meu desejo.

Fiz o que Luís Tinoco me pediu.

- Aquele moço que lá tem, quer fazer carreira política; pediu-me que to recomendasse.

- Que tal é ele?

- Não te posso dizer muita coisa a seu respeito; mas creio que é inteligente e pode ser aproveitado. Uma qualidade tem ele: é entusiasta e pode dedica-se ao partido.

Da recomendação sortiu efeito. O advogado disse a Luís Tinoco que o protegeria em tudo o que pudesse. Luís Tinoco não se fez mole. Na mesma noite escreveu um artigo político extenso e difuso, mas cheio de entusiasmo e fé.

O Dr. Lemos cedeu ao desejo de Luís Tinoco. Foi ter com o advogado e recomendou-lhe o escrevente, não com muita solicitude, mas também sem excessiva frieza. Felizmente o advogado era uma espécie de S. Francisco Xavier do partido, desejoso como ninguém de aumentar o pessoal militante; recebeu a recomendação com a melhor cara do mundo, e logo no dia seguinte, disse algumas palavras benévolas ao escrevente, que as ouviu trêmulo de comoção.

- Escreva alguma coisa, disse o advogado, e traga-me para ver se lhe achamos propensão.

Não foi preciso dizer-lho duas vezes. Dois dias depois, levou o ex-poeta ao seu protetor um artigo extenso e difuso, mas cheio de entusiasmo e fé. $\mathrm{O}$ advogado achou defeitos no trabalho; apontou-lhe demasias e nebulosidades, frouxidão de argumentos, mais ornamentação que solidez; todavia prometeu publicá-lo. Ou fosse porque lhe fizesse estas observações com muito jeito e benevolência, ou porque Luís Tinoco houvesse perdido alguma coisa da antiga suscetibilidade, ou porque a promessa da publicação lhe adoçasse o amargo da censura, ou por todas 
estas razões juntas, o certo é que ele ouviu com exemplar modéstia e alegria as palavras do protetor.

- Há de perder os defeitos com o tempo, disse este mostrando o artigo aos amigos.

O artigo foi publicado e Luís Tinoco recebeu alguns apertos de mão. Aquela doce e indefinível alegria que ele sentira quando estampou no Correio Mercantil os seus primeiros versos, voltou a experimentá-la agora, mas alegria complicada de uma virtuosa resolução: Luís Tinoco desde aquele dia sinceramente acreditou que tinha uma missão, que a natureza e o destino o haviam mandado à terra para endireitar os tortos políticos.

Nunca me há de esquecer o Poucas pessoas se terão esquecido do período final dessa da estreia política do ex-redator do Canapé literário Caramanchão Literário. Era assim: "Releve o poder - hipócrita e sanhudo, - que eu lhe diga muito humildemente que não temo o desprezo nem o martírio. Moisés mostrando aos Hebreus a conduzindo os hebreus à terra da promissão, simboliza a democracia mostrando ao povo a terra de liberdade. não teve a fortuna de entrar nela: é o símbolo do escritor que leva os homens à regeneração moral e política, sem lhe transpor as portas de ouro. Que poderia eu temer? Prometeu atado ao Cáucaso, Sócrates bebendo a cicuta, Cristo expirando na cruz, Savonarole indo ao sacrifício, Savanarola indo ao suplício, John Brown esperneando na forca, são os grandes apóstolos da liberdade e da luz, o exemplo e o conforto dos que amam a verdade, o remorso dos tiranos, a chuva de pedra das plaulações do despotismo! e o terremoto do despotismo."

$\mathrm{O}$ advogado achou que notar ao artigo de Luís Tinoco, mas desculpou-lhe as demasias, dizendo que, eram a expressão de um talento não assentado.

Luís Tinoco não parou; era uma roda viva. Escrevia todos os dias, o que tornava impossível a publicação de todos os seus trabalhos

Luís Tinoco não parou nestas primícias. Aquela mesma fecundidade da estação literária, veio a reproduzir-se na estação política; o protetor, entretanto, disse-lhe que era conveniente escrever menos e mais assentado. $\mathrm{O}$ ex-poeta não repeliu a advertência, e até lucrou com ela, produzindo alguns artigos menos desgrenhados no estilo e no pensamento. A erudição política de Luís Tinoco era nenhuma; o protetor emprestou-lhe alguns livros, que o ex-poeta aceitou com infinito prazer. Os leitores compreendem facilmente que o autor dos Goivos e Camélias não era homem que meditasse uma página de leitura; ele ia atrás das grandes frases, sobretudo das frases sonoras - demorava-se nelas, repetia-as, ruminava-as com verdadeira delícia. O que era reflexão, observação, análise parecia-lhe árido, e ele corria depressa por elas.

Pouco tempo depois houve uma eleição primária. Luís Tinoco foi apresentado ao eleitorado e venceu. O tio Anastácio não gostou de o ver assim metido na política, coisa que nunca lhe havia importado a ele. Fosse por isso ou por outra coisa, o certo é que o velho, já adoentado, veio a falecer pouco tempo depois da vitória eleitoral do sobrinho.

Era belo ver o rapaz na época da eleição, correndo pelas ruas no meio do povo, orando à multidão, gesticulando e ameaçando o governo. Força era reconhecer-lhe algum talento oratório; ao menos esse talento que seduz e arrasta os ânimos populares. 
O advogado estava contente com ele.

Luís Tinoco, porém, apesar das suas vitórias e dos elogios que lhe faziam, não estava contente.

Perguntei-lhe um dia que lhe faltava.

- Tudo, meu amigo, disse ele; eu sinto em mim a massa de um homem de estado. Quero subir muito e hei de subir. Mas compreendo bem que devo estar triste, se comparo a minha posição de eleitor com a que já devia ter na galeria política do país.

- Mas descanse; os generais começam assim também.

— É verdade. Demais...

- Demais?..

- É essa coisa que me entristece ${ }^{50}$

- O que é?

- A imprensa governista parece não fazer caso de mim. Até hoje não me respondeu a um só artigo. Será destino meu achar invejosos em toda a carreira que abraçar?

- É a partilha do talento.

- Tem razão.

Não tardou que o desejo de Luís Tinoco fosse satisfeito. A imprensa governista, vendo que alguns artigos de Luís Tinoco atacavam o ministério em pontos melindrosos, respondeu ao publicista; e aludindo à proteção que ele encontrara da parte do advogado, escreveu esta frase pérfida, mas usual:

"Aonde quererá ir, com semelhante descomedimento de linguagem, este pimpolho do ex-deputado Z?..."

Algum tempo depois houve uma eleição primária. O publicista sentiu que havia em si um eleitor, e foi dizê-lo afoitamente ao advogado. O desejo não foi mal aceito; trabalharam-se as coisas de modo que Luís Tinoco teve o gosto de ser incluído numa chapa e a surpresa de ficar batido. Batê-lo foi possível ao governo; abatê-lo, não. O ex-poeta, ainda quente do combate, traduziu em largos e floreados períodos o desprezo que lhe inspirava aquela vitória dos adversários. A esse artigo responderam os amigos do governo com um, que terminava assim: "Até onde quererá ir, com semelhante descomedimento de linguagem, o pimpolho do ex-deputado Z.?"

Luís Tinoco morre quase de júbilo. O seu artigo de resposta foi monumento no gênero.

A imprensa governista discutiu com ele algumas vezes; e desse modo ficaram satisfeitas as suas ambições de publicista.

Mas ele queria mais.

O que o seduzia era a tribuna parlamentar.

Luís Tinoco quase morreu de júbilo ao receber em cheio aquela descarga ministerial. A imprensa adversa não o havia tratado até então com a consideração que ele desejava. Uma ou outra vez, haviam discutido argumentos seus; mas faltava o melhor, faltava o ataque pessoal, que lhe parecia ser o batismo de fogo naquela espécie de campanha. O advogado, lendo o ataque, disse ao ex-poeta que a sua posição era idêntica à do primeiro Pitt quando o ministro Walpole lhe respondeu chamando-lhe moço em plena câmara dos comuns, e que era necessário repelir no mesmo tom a ofensa ministerial. Luís Tinoco ignorava até aquela data a existência de Pitt e de Walpole; achou todavia muito engenhosa a comparação das duas situações, e com habilidade e cautela perguntou ao advogado se the podia emprestar o discurso do orador britânico "para refrescar a memória". O advogado não tinha o discurso, mas deu-lhe ideia dele, quanto bastou para que Luís Tinoco

\footnotetext{
${ }^{50} J F$ ntristece
} 
fosse escrever um longo artigo acerca do que era e não era pimpolho ${ }^{51}$.

Poder subir à tribuna ainda que por metáfora, e de lá despejar os raios de cólera política contra o governo, derribá-lo com duas orações, e lançar mão do leme do Estado, tais eram os sonhos de nosso Luís Tinoco.

Ora, aconteceu que nesse tempo precisou o advogado de ter na sua província um jornal político e convidou Luís Tinoco para ir colocar-se à testa dele.

- Já sabe quais são as ideias, disse-lhe o advogado; vou recompensá-lo para as influências de lá, e bem pode ser que comece por lá mesmo uma carreira brilhante.

- É verdade! exclamou Luís Tinoco.

Aceitou.

- Dou-lhe os meus parabéns, disse-lhe eu quando ele me veio dar parte da comissão. É isso uma prova de confiança, e pode ser que dentro em pouco..

- Compreendo. Descanse.

Luís Tinoco partiu.

— Até breve, disse-me ele ao despedir-se.

- Volta breve?

- Voltarei deputado.

- Seja feliz..

- Adeus.

Fundou Luís Tinoco o jornal na província para onde fora mandado, e não se esqueceu de me mandar o primeiro número. Lá, encontrou ele menos indiferença que $e^{52}$ na Capital. Dentro em pouco tempo era ele só a bater-se com todos os órgãos adversos, e força é confessar que muita vez os vencia.

Deixei de ouvir falar no ex-poeta durante muitos meses.

Um dia recebi uma carta dele. Participava-me que era candidato à assembleia provincial e contava com a vitória.

Assim aconteceu.

A carta em que me deu parte do triunfo eleitoral era cheia de entusiasmo e de esperança. "Enfim, dizia ele, vou subir à tribuna política, objeto dos meus sonhos. Aqui à puridade, meu amigo, sinto em mim uma alma de Cícero.

Entretanto, a luta eleitoral the descobrira um novo talento. Como fosse necessário arengar algumas vezes, fê-lo o pimpolho a grande aprazimento seu e no meio de palmas gerais. Luís Tinoco perguntou a si mesmo se lhe era lícito aspirar às honras da tribuna. A resposta foi afirmativa. Esta nova ambição era mais difícil de satisfazer; o ex-poeta o reconheceu, e armou-se de paciência para esperar.

Aqui há uma lacuna na vida de Luís Tinoco. Razões que a história não conservou, levaram o jovem publicista à província natal do seu amigo e protetor, dois anos depois dos acontecimentos eleitorais. Não percamos tempo em conjecturar as causas desta viagem, nem as que ali o demoraram mais do que queria. Vamos já encontrá-lo alguns meses depois, colaborando num jornal com o mesmo ardor juvenil, de que dera tanta prova na capital. Recomendado pelo advogado aos seus amigos políticos e parentes, depressa criou Luís Tinoco um círculo de companheiros, e não tardou que assentasse em ali ficar algum tempo. O padrinho já estava morto; Luís Tinoco achava-se absolutamente sem família.

A ambição do orador não estava apagada pela satisfação do publicista; pelo contrário, uma coisa avivava a outra. A ideia de possuir duas armas, brandi-las ao mesmo tempo, ameaçar e bater com ambas os adversários, tornou-se-lhe ideia

\footnotetext{
${ }^{51} \mathrm{HMN}$ ipmpolho

${ }^{52} J F$ qne
} 
crônica, presente, inextinguível. Não era a vaidade que o levava, quero dizer, uma vaidade pueril. Luís Tinoco acreditava piamente que ele era um artigo do programa da Providência, e isso o sustinha e contentava. A sinceridade que nunca teve quando versificava os seus infortúnios entre suas palestras de rapazes, teve-a quando se enterrou a mais e mais na política. É claro que, se alguém lhe pusesse em dúvida o mérito político, feri-lo-ia do mesmo modo que os que the contestavam excelências literárias; mas não era só a vaidade que lhe ofendiam, era também, e muito mais, a fé - fé profunda e intolerante, — que ele tinha de que o seu talento fazia parte da harmonia universal.

Luís Tinoco mandava ao Dr. Lemos na Corte todos os seus escritos da província, e contava-lhe singelamente as suas novas esperanças. Um dia noticiouIhe que a sua eleição para a assembleia provincial era objeto de negociações que se lhe afiguravam propícias. O correio seguinte trouxe notícia de que a candidatura de Luís Tinoco entrara na ordem dos fatos consumados.

A eleição fez-se e não deu pouco trabalho ao candidato fluminense, que à força de muita luta e muito empenho pôde ter a honra de ser incluído na lista dos vencedores. Quando lhe deram notícia da vitória, entoou a alma de Luís Tinoco um verdadeiro e solene Te Deum Laudamus. Um suspiro, o mais entranhado e desentranhado de quantos suspiros jamais soltaram homens, desafogou o coração do ex-poeta das dúvidas e incertezas de longas e cruéis semanas. Estava enfim eleito! la subir o primeiro degrau do Capitólio.

A noite foi mal dormida, como a da véspera da publicação do primeiro soneto, e entremeada de sonhos análogos à situação. Luís Tinoco via-se já troando na Assembleia Provincial, entre os aplausos de uns, as imprecações de outros, a inveja de quase todos, e lendo em toda a imprensa da província os mais calorosos aplausos à sua nova e original eloquência. Vinte exórdios fez o jovem deputado para o primeiro discurso, cujo assunto seria naturalmente digno de grandes rasgos e nervosos períodos. Ele já estudava mentalmente os gestos, a atitude, todo o exterior da figura que ia honrar a sala dos representantes da província.

Muitos grandes nomes da política haviam começado no parlamento provincial. Era verossímil, era indispensável até, para que ele cumprisse o mandato imperativo do destino, que saísse dali em pouco tempo para vir transpor a porta mais ampla da reapresentação nacional. O ex-poeta ocupava já no espírito uma das cadeiras da Cadeia Velha, e remirava-se na própria pessoa e no brilhante papel que teria de desempenhar. Via já diante de si a oposição ou o ministério estatelado no chão, com quatro ou cinco daqueles golpes que ele supunha saber dar como ninguém, e as gazetas a falarem, e o povo a ocupar-se dele, e o seu nome a repercutir em todos os ângulos do império, e uma pasta a cair-lhe nas mãos, ao mesmo tempo que o bastão do comando ministerial.

Tudo isto, e muito mais imaginava o recente deputado, embrulhado nos lençóis, com a cabeça no travesseiro, e o espírito a vagar por esse mundo fora, 
que é a coisa ${ }^{53}$ pior que pode acontecer a um corpo mortificado como estava o dele naquela ocasião.

Não se demorou Luís Tinoco em escrever ao Dr. Lemos, e contar-lhe as suas esperanças e o programa que tencionava observar, desde que a fortuna lhe abria mais ampla estrada na vida pública. A carta tratava longamente do efeito provável da sua primeira oração, e terminava assim: "Qualquer que seja o posto a que eu suba; qualquer, entenda bem, ainda aquele que é o primeiro do país, abaixo do imperador (e creio que irei até lá), nunca me há de esquecer que ao senhor o devo, à animação que me dispensou, à recomendação que fez de mim. Parece-me que até hoje tenho correspondido à confiança dos meus amigos; espero continuar a merecê-la."

Inauguraram-se enfim os trabalhos. Tão desejoso estava ansioso estava Luís Tinoco de falar que, logo nas primeiras sessões, a propósito de um projeto sobre a colocação de um chafariz, fez um discurso de duas horas em que ele demonstrou por $\mathrm{A}+\mathrm{B}$ que a água era necessária ao homem. § Mas a grande batalha foi dada na discussão do orçamento provincial. Luís Tinoco fez um longo discurso em que combateu o governo geral, o presidente, os adversários, a polícia e o despotismo. § Foi coberto de aplausos. Seus gestos eram até então desconhecidos na escala da gesticulação parlamentar; na província, pelo menos, ninguém tivera nunca a satisfação de contemplar aquele sacudir de cabeça, aquele arquear de braço, aquele apontar, alçar, cair e bater com a mão direita.

O estilo também não era vulgar. Nunca se falou de receita e despesa com maior luxo de imagens e figuras. A receita foi comparada ao orvalho que as flores recolhem durante a noite; a despesa à brisa da manhã que as sacode e lhes entorna um pouco do sereno vivificante. Um bom governo é apenas brisa; o presidente atual foi declarado siroco e pampeiro. Toda a maioria protestou solenemente contra essa qualificação injuriosa, ainda que poética. Um dos secretários confessou que nunca do Rio de Janeiro lhes fora uma aura mais refrigerante.

Infelizmente os adversários não dormiam, e um deles, obtendo a palavra, puxou - Um deles, apenas Luís Tinoco acabou o discurso entre alguns aplausos dos seus amigos, pediu a palavra e cravou longo tempo os olhos no orador estreante. Depois sacou do bolso um maço de jornais e um folheto, concertou a garganta e disse:

- "Mandaram-nos do Rio de Janeiro o nobre deputado que me precedeu nesta tribuna. Diziam que era uma ilustração fluminense, destinada a arrasar os talentos da roça província. Imediatamente, Sr. presidente, tratei de obter as obras do nobre deputado."

"Aqui tenho eu, Sr. presidente, o canapé literário Caramanchão Literário, folha

\footnotetext{
${ }^{53} \mathrm{HMN}$ cois
} 
redigida pelo meu adversário, e o volume dos Goivos e Camélias. Tenho lá em casa mais outras obras. §"Abramos os Goivos e Camélias.

O SR LUÍS TINOCO: - O nobre deputado está fora da ordem! (Apoiados Apoiados).

O orador: ; - Continuo, Sr. presidente; aqui tenho os Goivos e Camélias. Vejamos um goivo.

A Ela.

Quem és tu que me atormentas

Com teus prazenteiros sorrisos?

Quem és tu que me apontas

As portas dos paraísos?

Imagem do céu és tu?

És filha da divindade?

Ou vens prender em teus cabelos

A minha liberdade?

"Vê V. Ex. ", Sr. presidente, que já neste nesse tempo o nobre deputado era inimigo de todas as leis opressoras. A assembleia tem visto como ele trata as leis da rima do metro."

O discurso continuou por este tom. Luís Tinoco respondeu-lhe com veemência e indignação. Teve ocasião de inspiração real, mas a tática do adversário produziu efeito; Luís Tinoco envergonhou-se e não voltou à assembleia.

Decorreram quatro anos, sem que eu ouvisse falar de Luís Tinoco.

Precisei um dia ir à província onde ele estava; fui ter com o advogado a ver se me dava indicação do rapaz. Mas o advogado estava fora da cidade.

Parti sem indicação nenhuma.

Quando cheguei, procurei o jornal que Luís Tinoco redigira; já não existia desde muito. Do próprio Luís Tinoco ninguém me deu notícias. Mas ao fim de oito dias recebi uma carta do interior; era Luís Tinoco que me convidava a ir vê-lo.

Fui.

Morava em uma soberba casa e possuía grandes terrenos que cultivava. Estava casado, e já tinha dois filhos; jogava o gamão, não votava, não lia jornais, nem fazia versos.

- Como se operou tamanha mudança? perguntei eu.

- Meu amigo, disse ele: convenci-me de que não era fadado para grandes destinos, conforme supunha, e desde que essa convicção me passou voltei à prática da vida.

- Mas...

- O quê?

- Como é que lhe nasceu essa convicção?

- Ouvindo ler os meus versos na assembleia. Reconheci naquela ocasião quanto eram pífios os tais versos; e para logo pensei comigo que eu olharia mais tarde para as minhas obras políticas com a vergonha que então olhava para as minhas obras poéticas. Uma noite de reflexão, nada mais.

- Ora, estimo muito, disse-lhe eu. Agora nenhuma ambição mais?

- Nenhuma; enriquecerei se puder, e educarei os filhos para lavradores, salvo se algum deles tiver aptidão real para outra coisa.

Despedi-me de Luís Tinoco. Está vivo e vai enriquecendo. Conta hoje mais dois filhos. 
"Aurora sem dia"

Assim acabaram as ambições do autor dos Tupinambás e dos Goivos e Camélias, do publicista fogoso e do eloquente deputado.

Foi uma aurora sem dia.

Todo o resto do discurso foi assim. A minoria protestou, Luís Tinoco fez-se de todas as cores, e a sessão acabou em risada. No dia seguinte os jornais amigos de Luís Tinoco agradeceram ao adversário deste o triunfo que lhe proporcionou mostrando à província "uma antiga e brilhante face do talento do ilustre deputado". Os que indecorosamente riram dos versos, foram condenados com estas poucas linhas: "Há dias um deputado governista disse que a situação era uma caravana de homens honestos e bons. É caravana, não há dúvida; vimos ontem os seus camelos".

Nem por isso Luís Tinoco ficou mais consolado. As cartas do deputado ao Dr. Lemos começaram a escassear, até que de todo cessaram de aparecer. Decorreram assim silenciosos uns três anos, ao cabo dos quais o Dr. Lemos foi nomeado não sei para que cargo na província onde se achava Luís Tinoco. Partiu. Apenas empossado do cargo, tratou de procurar o ex-poeta, e pouco tempo gastou, recebendo logo um convite dele para ir a um estabelecimento rural onde se achava.

- Há de me chamar ingrato, não? disse Luís Tinoco, apenas viu assomar à porta de casa o Dr. Lemos. Mas não sou; contava ir vê-lo daqui a um ano; e se Ihe não escrevi... Mas que tem, doutor? está espantado?

O Dr. Lemos estava efetivamente pasmado a olhar para a figura de Luís Tinoco. Era aquele o poeta dos Goivos e amélias, o eloquente deputado, o fogoso publicista? O que ele tinha diante de si era um honrado e pacato lavrador, ar e maneiras rústicas, sem o menor vestígio das atitudes melancólicas do poeta, do gesto arrebatado do tribuno, - uma transformação, uma criatura muito outra e muito melhor.

Riram-se ambos, um da mudança, outro do espanto, pedindo o Dr. Lemos a Luís Tinoco lhe dissesse se era certo haver deixado a política, ou se aquilo eram apenas umas férias para renovar a alma.

- Tudo lhe explicarei, doutor, mas há de ser depois de ter examinado a minha casa e a minha roça, depois de lhe apresentar minha mulher e meus filhos...

- Casado?

- Há vinte meses.

- E não me disse nada!

- la este ano à Corte e esperava surpreendê-lo... Que duas criancinhas as minhas... lindas como dois anjos. Saem à mãe, que é a flor da província. Oxalá se pareçam também com ela nas qualidades de dona de casa; que atividade! que economia!...

Feita a apresentação, beijadas as crianças, examinado tudo, Luís Tinoco declarou ao Dr. Lemos que definitivamente deixara a política. 
- De vez?

- De vez.

- Mas que motivo? desgostos, naturalmente.

- Não; descobri que não era fadado para grandes destinos. Um dia leramme na assembleia alguns versos meus. Reconheci então quanto eram pífios os tais versos; e podendo vir mais tarde a olhar com a mesma lástima e igual arrependimento para as minhas obras políticas, arrepiei carreira e deixei a vida pública. Uma noite de reflexão e nada mais.

— Pois teve ânimo?...

- Tive, meu amigo, tive ânimo de pisar terreno sólido, em vez de patinhar nas ilusões dos primeiros dias. Eu era um ridículo poeta e talvez ainda mais ridículo orador. Minha vocação era esta. Com poucos anos mais estou rico. Ande agora beber o café que nos espera e feche a boca, que as moscas andam no ar.

\section{5 "O relógio de ouro"}

\section{O relógio de ouro}

Agora contarei a história do relógio de ouro. § Era um grande cronômetro, novinho e trabalhando sobre umas quantas pedras preciosasinteiramente novo, preso a uma elegante cadeia. Luís Negreiros tinha muita razão em ficar boquiaberto quando viu o relógio em casa, um relógio que não era dele, nem podia ser de sua mulher. Seria ilusão dos seus olhos? Não era; o relógio ali estava sobre uma mesa da alcova, a olhar para ele, talvez tão espantado, como ele, do lugar e da situação.

Clarinha não estava na alcova quando Luís Negreiros ali entrou. Deixouse ficar na sala, a folhear um romance, sem corresponder muito nem pouco ao ósculo com que o marido a cumprimentou logo à entrada. §Era uma bonita moça esta Clarinha, ainda que um tanto pálida, ou por isso mesmo; era. Era pequena e delgada. De; de longe parecia uma criança; de perto, quem lhe examinasse os olhos, veria bem que era mulher como poucas. $\S$ Estava molemente reclinada no sofá, com o livro aberto, e os olhos no livro, os olhos apenas, porque o pensamento, não tenho certeza se estava no livro, se em outra parte. Em todo o caso parecia alheia ao marido e ao relógio.

Luís Negreiros lançou mão do relógio com uma expressão que eu não me atrevo a descrever. Nem o relógio, nem a corrente eram dele; também não eram de pessoas suas conhecidas. § Tratava-se de uma charada. § Luís Negreiros gostava de charadas, e passava por ser decifrador intrépido; mas gostava de charadas nos almanaques nas folhinhas ou nos jornais de moda. 
Charadas vivas ou palpáveis ou cronométricas, e sobretudo sem conceito, não as apreciava Luís Negreiros.

Por este motivo, e outros que são óbvios, compreenderá o leitor que o esposo de Clarinha se atirasse sobre uma cadeira, puxasse raivosamente os cabelos, batesse com o pé no chão, e atirasse lançasse o relógio e a corrente sobre a mesa para cima da mesa.§ Terminada esta primeira manifestação de furor, Luís Negreiros pegou de novo nos fatais objetos, e de novo os examinou. $\S$ Ficou na mesma. §Cruzou os braços durante algum tempo e refletiu sobre o caso, interrogou todas as suas recordações, e concluiu no fim de tudo que, sem uma explicação de Clarinha, todo o seu qualquer procedimento fora baldado ou precipitado.

Saiu à sala Foi ter com ela.

Clarinha acabava justamente de ler uma página e voltava a folha com $\mathrm{o}$ ar indiferente e tranquilo de quem não pensa em decifrar charadas de cronômetro. Luís Negreiros encarou-a; seus olhos pareciam dois reluzentes punhais.

— Que tens? perguntou a moça com a voz doce e meiga que toda a gente concordava em lhe achar.

Luís Negreiros não respondeu à interrogação da mulher; olhou algum tempo para ela, e; depois deu duas voltas na sala, passando a mão pelos cabelos, e fazendo outros gestos tais, por modo que a moça de novo lhe perguntou:

- Que tens?

Luís Negreiros parou defronte dela.

- Que é isto? perguntou disse ele tirando do bolso o fatal relógio e apresentando-lho diante dos olhos. Que é isto? repetiu ele com voz de trovão.

Clarinha mordeu os beiços e não respondeu. § Luís Negreiros esteve algum tempo com o relógio na mão e os olhos na mulher, a qual tinha os seus olhos no livro. §O silêncio era profundo.§ Luís Negreiros foi o primeiro que o rompeu, atirando estrepitosamente o relógio ao chão, e dizendo em seguida à esposa:

— Vamos, de quem é aquele relógio?

Clarinha ergueu lentamente os olhos para ele, abaixou-os depois, e murmurou:

- Não sei.

Luís Negreiros fez um gesto como de quem queria esganá-la; contevese. A mulher levantou-se, apanhou o relógio e pô-lo sobre uma mesa pequena. §Não se pôde conter sofrer Luís Negreiros. §Caminhou para ela, e, segurando-lhe nos pulsos com força, lhe disse:

- Não me responderás, demônio? Não me explicarás esse enigma?

Clarinha fez um gesto de dor, e Luís Negreiros imediatamente lhe soltou os pulsos que estavam arrochados. Noutras circunstâncias é provável que 
Luís Negreiros lhe caísse aos pés e pedisse perdão de a haver machucado. Naquele nem se lembrou disso; deixou-a no meio da sala e entrou a passear de novo, sempre agitado, parando de quando em quando, como se meditasse algum desfecho trágico.

Clarinha saiu da sala.

Pouco depois veio um escravo dizer que o jantar estava na mesa.

- Onde está a senhora?

- Não, sei, não senhor.

Luís Negreiros foi procurar a mulher; achou-a numa saleta de costuras costura, sentada numa cadeira baixa, com a cabeça nas mãos a soluçar. § Ao ruído que ele fez na ocasião de fechar a porta atrás de si, Clarinha levantou a cabeça, e Luís Negreiros pôde ver-lhe as faces úmidas de lágrimas. §Esta situação foi ainda pior para ele que a da sala. Luís Negreiros não podia ver chorar uma mulher, e sobretudo a dele. § Ia enxugar-lhe as lágrimas com um beijo, mas de novo se conteve reprimiu o gesto, e caminhou frio para ela; puxou uma cadeira e sentou-se em frente de Clarinha.

- Estou tranquilo, como vês, disse ele;,responde-me ao que te perguntei com a franqueza que sempre usaste comigo. Eu não te acuso nem suspeito nada de ti. Quisera simplesmente saber como foi parar ali aquele relógio. Foi teu pai que o esqueceu cá !?

- Não.

- Mas então...

- Oh! não me perguntes nada! exclamou Clarinha ;- ignoro como esse relógio se ache acha ali... Não sei de quem é... deixa-me.

—É demais! urrou Luís Negreiros, levantando-se e atirando a cadeira ao chão.

Clarinha estremeceu, e deixou-se ficar onde estava. § A situação tornavase cada vez mais grave; Luís Negreiros passeava cada vez mais agitado, revolvendo os olhos nas órbitas, e parecendo prestes a atirar-se sobre a infeliz esposa. Esta, com os cotovelos no regaço e a cabeça nas mãos, tinha os olhos encravados na parede. §Correu assim cerca de um quarto de hora. $\S$ Luís Negreiros ia de novo interrogar a esposa, quando ouviu a voz do sogro, que subia ${ }^{54}$ as escadas, gritando:

— Ó sr seu Luís! ó sr seu malandrim!

- Aí vem teu pai! disse Luís Negreiros; logo me pagarás.

Saiu da sala de costura e foi receber o sogro, que já estava no meio da sala, fazendo viravoltas com o chapéu de sol, com grande risco das jarras e do candelabro.

${ }^{54} J F$ sabia 
- Vocês estavam dormindo? perguntou o Sr. Meireles tirando o chapéu e limpando a testa com um grande lenço encarnado.

- Não, senhor, estávamos conversando...

- Conversando?... repetiu baixinho Meireles.

E acrescentou consigo:

- Estavam de arrufos... é o que há de ser.

- Vamos justamente jantar, disse Luís Negreiros. Janta conosco?

- Não vim cá para outra coisa, acudiu Meireles; janto cá hoje e amanhã também. Não me convidaste, mas é o mesmo.

- Não o convidei?...

— Sim, não fazes anos amanhã?

- Ah! é verdade...

Não havia razão aparente para que, depois destas palavras ditas com um tom lúgubre, Luís Negreiros repetisse, mas desta vez com um tom descomunalmente alegre:

- Ah! é verdade!...

Meireles, que já ia a pôr o chapéu num cabide ${ }^{55}$ do corredor, voltou-se espantado para o genro, em cujo rosto leu a mais franca, súbita e inexplicável alegria.

— Está maluco! disse baixinho Meireles.

- Vamos jantar, bradou o genro, indo logo para dentro, enquanto Meireles seguindo pelo corredor ia ter à sala de jantar.

Luís Negreiros foi ter com a mulher na sala de costura, e achou-a de pé, compondo os cabelos diante de um pequeno espelho:

- Obrigado, disse ele entrando.

A moça olhou para ele admirada.

- Obrigado, repetiu Luís Negreiros; obrigado e perdoa-me.

Dizendo isto, procurou Luís Negreiros abraçá-la; mas a moça, com um gesto nobre, repeliu o afago do marido e foi para a sala de jantar.

- Tem razão! murmurou Luís Negreiros.

Daí a pouco achavam-se todos três à mesa do jantar, e foi servida a sopa, que Meireles achou, como era natural, de gelo. Ia já fazer um discurso a respeito da incúria dos criados, quando Luís Negreiros confessou que toda a culpa era dele, porque o jantar estava há muito na mesa. A declaração apenas mudou o assunto do discurso, que versou então sobre a terrível coisa que era um jantar requentado, ideia que o poeta já havia resumido neste verso tornado axioma:

Un diner réchauffé ne valut jamais rien.

${ }^{55} J F$ cabido 
"O relógio de ouro"

- qui ne valut jamais rien.

Meireles era um homem alegre, pilhérico, talvez frívolo demais para a idade e a posição que ocupava. O genro gostava muito de o ter à mesa. Infelizmente havia um ponto negro na sociedade; Clarinha estava triste e poucas palavras respondia às muitas que the dirigiam o marido e o pai, mas em todo o caso interessante pessoa. Luís Negreiros gostava muito dele, e via correspondida essa afeição de parente e de amigo, tanto mais sincera quanto que Meireles só tarde e de má vontade lhe dera a filha. Durou o namoro cerca de quatro anos, gastando o pai de Clarinha mais de dois em meditar e resolver o assunto do casamento. Afinal deu a sua decisão, levado antes das lágrimas da filha que dos predicados do genro, dizia ele.

A causa da longa hesitação eram os costumes pouco austeros de Luís Negreiros, não os que ele tinha durante o namoro, mas os que tivera antes e os que poderia vir a ter depois. Meireles confessava ingenuamente que fora marido pouco exemplar, e achava que por isso mesmo devia dar à filha melhor esposo do que ele. Luís Negreiros desmentiu as apreensões do sogro; o leão impetuoso dos outros dias, tornou-se um pacato cordeiro. A amizade nasceu franca entre o sogro e o genro, e Clarinha passou a ser uma das mais invejadas moças da cidade.

E era tanto maior o mérito de Luís Negreiros quanto que não lhe faltavam tentações. O diabo metia-se às vezes na pele de um amigo e ia convidá-lo a uma recordação dos antigos tempos. Mas Luís Negreiros dizia que se recolhera a bom porto e não queria arriscar-se outra vez às tormentas do alto mar.

Clarinha amava ternamente o marido, e era a mais dócil afável criatura que por aqueles tempos respirava o ar fluminense. Nunca entre ambos se dera o menor arrufo; a limpidez do céu conjugal era sempre a mesma e parecia vir a ser duradoura. Que mau destino lhe soprou ali a primeira nuvem?

Durante o jantar Clarinha não disse palavra, — ou poucas dissera, ainda assim as mais breves e em tom seco.

— Estão ${ }^{56}$ de arrufo, não há dúvida, pensou Meireles ao ver a pertinaz mudez da filha. Ou a arrufada é só ela, porque ele parece-me lépido ... .

Luís Negreiros efetivamente desfazia-se todo em agrados, mimos e cortesias com a mulher, que nem sequer olhava em cheio para ele. $\mathrm{O}$ marido já dava o sogro a todos os diabos, desejoso de ficar a sós com a mulher esposa, para a explicação última, que reconciliaria os ânimos. Clarinha não parecia desejá-lo; comeu pouco e duas ou três vezes soltou-se-lhe do peito um suspiro.

Já se vê que o jantar, por maiores que fossem os esforços, não podia ser como nos outros dias. Meireles sobretudo achava-se acanhado. Não era que receasse algum grande acontecimento em casa; sua ideia é que sem arrufos não se aprecia a felicidade, como sem tempestade não se aprecia

\footnotetext{
${ }^{56} J F$ Estam
} 
o bom tempo. Era lá a sua ideia. Entretanto Contudo, a tristeza da filha sempre lhe punha água na fervura.

Quando veio o café, Meireles propôs que fossem todos três ao teatro; Luís Negreiros aceitou a ideia com entusiasmo. Clarinha recusou secamente.

- Não te entendo hoje, Clarinha, disse o pai com um modo impaciente. Teu marido está alegre e tu pareces-me abatida e preocupada. Que tens tu?

Clarinha não respondeu; Luís Negreiros, sem saber o que havia de dizer, tomou a resolução de fazer bolinhas com o de miolo de pão que havia sobre a mesa. Meireles levantou os ombros.

- Vocês lá se entendem, disse ele. Se amanhã, apesar de ser o dia que é, vocês estiverem do mesmo modo, protesto prometo-lhes que nem a sombra me verão.

— Oh! há de vir, ia dizendo Luís Negreiros, mas foi interrompido pela mulher que desatou a chorar.

O jantar acabou assim triste e aborrecido. Meireles pediu ao genro que lhe explicasse o que aquilo era, e este prometeu que lhe diria tudo em ocasião oportuna.

Pouco depois saía o pai de Clarinha protestando de novo que, se no dia seguinte os achasse do mesmo modo, nunca mais voltaria à casa deles, e que se havia coisa pior que um jantar frio ou requentado, era um jantar mal digerido. Outras muitas coisas mais disse o sogro de Luís Negreiros, mas como não interessam à história, deixo-as de referir nesta ocasião Este axioma valia o de Boileau, mas ninguém lhe prestou atenção.

Clarinha fora para o quarto; o marido, apenas se despediu do sogro, foi ter com ela. Achou-a sentada na cama, com a cabeça sobre uma almofada, e soluçando. Luís Negreiros ajoelhou-se diante dela e pegou-lhe numa das mãos.

- Clarinha, disse ele, perdoa-me tudo. Já tenho a explicação do relógio; se teu pai não me fala em vir cájantar amanhã, eu não era capaz de adivinhar que o relógio era um presente de anos que tu me fazias.

Não me atrevo a descrever o soberbo gesto de indignação com que a moça se pôs de pé quando ouviu estas palavras do marido. Luís Negreiros olhou para ela sem compreender nada. A moça não disse uma nem duas; saiu do quarto e deixou o infeliz consorte mais intrigado admirado que nunca.

- Mas que enigma é este? perguntava a si mesmo Luís Negreiros. Mas então se Se não era um mimo de anos, que explicação pode ter o tal relógio?

A situação era a mesma que antes do jantar. Luís Negreiros assentou de descobrir tudo nessa mesma naquela noite. Achou, entretanto, que era conveniente refletir maduramente no caso e assentar numa resolução que fosse decisiva. §Com este propósito recolheu-se ao seu gabinete, e ali recordou 
tudo o que se havia passado desde que chegara a casa. Pesou friamente todas as razões, todos os incidentes, e buscou reproduzir na memória a expressão do rosto da moça, em toda aquela tarde. O gesto de indignação e a repulsa quando ele a foi abraçar na sala de costura, eram a favor dela; mas o movimento com que mordera os lábios no momento em que ele lhe apresentou o relógio, as lágrimas que lhe rebentaram à mesa, e mais que tudo o silêncio que ela conservava a respeito da procedência do fatal objeto, tudo isso falava contra a moça.

Luís Negreiros, depois de muito e muito cogitar, inclinou-se à mais triste e deplorável das hipóteses. Abriu a secretária, e tirou de dentro de uma gaveta secreta um revólver de seis tiros. Estava carregada. Meteu-o no bolso, Uma ideia má começou a enterrar-se-lhe no espírito, à maneira de verruma, e tão fundo penetrou, que se apoderou dele em poucos instantes. Luís Negreiros era homem assomado quando a ocasião o pedia. Proferiu duas ou três ameaças, saiu do gabinete e foi ter com a mulher.

Clarinha recolhera-se de novo ao quarto. A porta estava apenas cerrada. Eram nove horas da noite. Uma pequena lamparina alumiava escassamente o aposento. § A moça estava outra vez assentada na cama, mas já não chorava; tinha os olhos fitos no chão. Nem os levantou quando sentiu entrar o marido.

Houve um momento de silêncio.

Luís Negreiros foi o primeiro que falou.

- Clarinha, disse ele, este momento é solene. Responde-me ao que te pergunto desde esta tarde?

A moça não respondeu.

- Reflete bem, Clarinha, continuou o marido. Podes arriscar a tua vida.

A moça levantou os ombros.

Uma nuvem passou pelos olhos de Luís Negreiros. Dentro de alguns segundos tinha Clarinha diante de si o revólver que o marido lhe apontava ao peito. $\mathrm{O}$ infeliz marido lançou as mãos ao colo da esposa e rugiu:

- Responde, demônio, ou morres!

Clarinha soltou um grito.

- Espera! disse ela.

Luís Negreiros abaixou a arma recuou.

- Mata-me, disse ela, mas lê isto primeiro. Quando esta carta foi ao teu escritório já te não achou lá: foi o que o portador me disse.

Luís Negreiros recebeu a carta; , chegou-se à lamparina e leu estupefato estas linhas:

"Meu bebê nhonhô. Sei que amanhã fazes anos; mando-te esta lembrança.

- Tua Zeferinalaiá."

Imagine o leitor o pasmo, a vergonha, o remorso de Luís Negreiros, admire a constância de Clarinha e a vingança que tomara, e de nenhum modo lastime a boa Zeferina, que foi totalmente esquecida, sendo perdoado 
Luís Negreiros, e tendo Meireles o gosto de jantar com a filha e o genro no dia seguinte.

Assim acabou a história do relógio de ouro.

\title{
3.6 "Quem desdenha" / "Ponto de vista"
}

\author{
Quem desdenha...
}

Ponto de vista

Prefácio

Não lhes posso dizer como vieram estas cartas para as minhas mãos; afianço porém que são autênticas. Minha primeira ideia foi tirar do conteúdo delas o enredo de uma narrativa e fazer obra minha; assentei porém que era melhor transcrever as cartas sem lhes cortar uma vírgula salvo o final da carta $\mathrm{V}$, por tratar exclusivamente de modas.

Dou a palavra às epístolas.

A D. Luísa P..., em Juiz de Fora.

Corte, 5 de Outubro.

Não me dirá a quem entregou você as encomendas que lhe pedi? $\mathrm{Na}$ sua carta vem mal escrito o nome do portador; e até hoje nem sombra dele, quem quer que seja. Será o Luís?

Ouvi dizer que você vinha para cá passar algum tempo; estimaria muito que assim fosse. Havia de gostar disto agora, apesar do calor, que tem sido forte. Hoje entretanto temos um dia excelente.

Ou então, no caso de não vir, estimaria muito ir eu para lá; mas papai, como você sabe, ninguém há que o tire dos seus cômodos; e mamãe anda meio adoentada. Vontade teria ela de me ser agradável, mas eu é que não sou tão egoísta. E olha olhe que perco muito; porque, além de ir ver a minha melhor amiga, iria ao mesmo tempo verificar se é verdade que ainda não tem esperanças de um nenê. Alguém me disse que sim. Por que nega você isso? 
Esta carta irá amanhã. Escreva-me logo; e dê muitas lembranças ao a seu marido, minhas e de todos nós. Adeus. Tua, Raquel.

Adeus.

Raquel

\section{II}

À mesma.

Corte, 15 de Outubro.

Gastou muitos dias, mas veio uma carta longa, e, apesar disso, curta. Obrigada pelo trabalho; mas não seja essa a única peço-lhe que o repita ; detesto aborreço os seus bilhetinhos, escritos às carreiras, com o pensamento... em quem? Nesse marido cruel que só cuida de eleições, segundo li outro dia. Eu escrevo cartinhas quando não tenho tempo para mais. Mas quando me sobra o tempo escrevo cartões. Creio que disse uma tolice; desculpa-me desculpeme.

Vieram as encomendas logo no dia seguinte ao da minha última carta. E que quer você que eu lhe mande? Tenho aqui uns figurinos recebidos ontem, mas não tenho há portador. Se puder arranjar algum por estes dias irá também um romance que me trouxeram esta semana. Chama-se Ruth. Conheces Conhece?

A Mariquinhas Rocha vai casar. Que pena! tão bonitinha, tão boa, tão terna criança, vai casar... com um sujeito velho! E não é só isto: casa-se por amor. Eu duvidei de semelhante coisa; mas todos dizem que tanto o pai como os mais parentes procuraram dissuadi-la de semelhante projeto, mas ela insistiu a ponto ; ela porém insistiu de maneira que ninguém mais ousou opor-se-lhe se Ihe opôs.

A falar verdade, ele não está a cair de maduro; é velho, mas elegante, gamenho, robusto; , alegre, diz muitas pilhérias, e parece que tem bom coração. Não era eu que caía apesar de tudo isto. Que consórcio pode haver entre uma rosa e uma carapuça?

Antes, mil vezes antes, casasse ela com o filho do noivo; esse sim, é um rapaz digno de merecer uma moça como ela. Dizem que é um bandoleiro dos quatro costados; mas você sabe que eu não creio em bandoleiros. Quando uma pessoa quer, vence o coração mais versátil deste mundo.

O casamento parece que será daqui a dois meses. Irei naturalmente às exéquias, quero dizer às bodas. Pobre Mariquinhas! Lembra-se ${ }^{57}$ das

\footnotetext{
${ }^{57} J F$ lembra-se
} 
nossas tardes no colégio? Ela ${ }^{58}$ era a mais quieta de todas, e a mais cheia de melancolia. Parece que adivinhava este destino.

Papai aprovou muito a escolha dela; tem-na elogiado muito faz-lhe muitos elogios como pessoa de juízo, e chegou a dizer que eu devia fazer o mesmo. Que lhe parece? Eu, se tivesse de seguir algum exemplo, seguia o da minha Luísa; essa sim, é que teve dedo para escolherconsorte ... Não mostres mostre esta carta a teu seu marido; é capaz de arrebentar de vaidade.

E vocês não vêm para cá? É pena; dizem que vamos ter companhia lírica, e mamãe está melhor. Quer dizer que vou passar durante algum tempo uma algum tempo de vida excelente. O futuro enteado da Mariquinhas, o tal que ela devia escolher em lugar do pai, afirma que a companhia é magnífica. Seja ou não, é mais um divertimento. E tu você lá na roça!...

Vou jantar; adeus. Escreve-me quando puderes Escreva-me quando puder, mas nada de cartas microscópicas. Ou muito ou nada. Tua, Raquel.

Raquel

III

À mesma.

Corte, 17 de Outubro.

Escrevi-lhe anteontem uma carta, e acrescento hoje um bilhetinho (sem exemplo) para dizer que o velho noivo da Mariquinhas inspirou paixão a outra moça, que adoeceu de desespero. É uma história complicada. Compreende isto? Se fosse o filho, vá; mas o pai! Raquel.

${ }^{58} J F$ ela 
$\grave{A}$ mesma.

Corte, 30 de Outubro.

Muito velhaca é você! . § Então porque lhe falei duas ou três vezes no tal rapaz, imagina logo que estou apaixonada por ele? Papai nestes casos costuma dizer que é falta de lógica. Eu digo que é falta de amizade.

E provo.

Pois se eu tivesse algum namoro, afeição ou coisa assim, a quem diria em primeiro lugar senão a você? Não fomos durante tanto tempo confidentes uma da outra? Supor-me tão reservada é não me ter amizade nenhuma; porque a falta de afeição é que traz a injustiça.

Não, Luísa, eu nada sinto por esse moço, a quem conheço de poucos dias. Falei nele muitas algumas vezes por comparação com o pai; se eu estivesse disposta a casar-me, certamente que antes o queria que preferia o moço ao velho. Mas é só isto e nada mais.

Nem imagine que o Dr. Alberto (é o nome dele) vale muito; é bonito e elegante, mas tem ar pretensioso e parece-me um espírito curto. Você sabe como eu sou exigente nesses assuntos. Se eu não achar marido como imagino, fico solteira toda a minha vida. Antes isso, que ficar presa a um cepo, ainda que esbelto.

Também não basta ter as qualidades os predicados que eu imagino para me seduzir logo. Anda agora aqui em casa um sujeito que nos foi apresentado há pouco tempo; qualquer outra moça ficava presa pelas maneiras dele; a mim não me faz a menor impressão.

E por quê?

A razão é simples; toda a graça que ele ostenta, toda a afeição que simula, todos os cortejos que me faz, quer saber o que é, Luísa? é que eu sou rica. Este sujeito quer arranjar posição; parece que há muitos deste jaez. Eu tenho bastante finura para os conhecer. E não caio. § Descanse; quando me aparecer aquele que o céu me destina, você será a primeira a ter notícia. Por ora estou livre, como as andorinhas que estão agora a passear na chácara.

E para vingar-me da calúnia, não escrevo mais. § Adeus. 
À mesma.

Corte, 15 de Novembro.

Estive doente estes dois dias; foi uma constipação forte que apanhei saindo do Ginásio, onde fui ver uma peça nova, muito falada e muito insípida.

Sabe você quem estava lá? A Mariquinhas com o noivo no camarote, e o enteado também, o futuro enteado, se Deus quiser. § Não se pode imaginar como ela parecia contente, como conversava com ele. E olha ela conversava com o noivo! E olhe que de longe, à luz do gás, o tal velho é quase tão moço como o filho. Quem sabe? Bem pode ser que ela viva feliz!

Dou-lhe muitos parabéns pela notícia que me dás dá de que brevemente veremos um nenê. A mamãe também lhe manda parabéns. §O Luís leva com esta carta uns figurinos...

Raquel

À mesma.

Corte, 27 de Novembro.

A sua carta chegou quando estávamos almoçando, e foi bom tê-la lido depois, porque se a leio antes não acabava de almoçar. §Que história é essa, e quem lhe meteu na cabeça semelhante coisa? Eu, namorada de do Alberto! Isso é caçoada de mau gosto, Luísa! Se alguém lhe mandou dizer tal, teve certamente intenção de me envergonhar. § Se você o conhecesse, não era necessário este meu protesto. Já lhe disse as boas qualidades dele, mas os seus defeitos são para mim superiores às qualidades. Você bem sabe como eu sou; a menor mancha para mim a menor nódoa destrói no meu espírito a beleza de uma a maior alvura. Uma estátua $\S \mathrm{E}$... estátua cabe neste caso é o termo próprio, porque o tal Alberto elegante como já disse, tem certa rigidez escultural. Cuido que estuda as posições. E que se há de pensar de um homem assim?

\footnotetext{
${ }^{59}$ Suprime-se o resto da carta que trata só de modas.
} 
Ah! Luísa, o homem que o céu me destina ainda não veio. Sei que não veio porque ainda não senti dentro de mim aquele estremecimento simpático que indica a harmonia de duas almas. Quando ele vier, fica fique certa de que serás será a primeira a quem eu confiarei tudo.

Dir-me-á que, se eu sou assim fatalista, devo admitir a possibilidade de um marido sem todas as condições que eu exijo.

Engano.

Deus que me fez assim, e me deu esta percepção íntima para conhecer e amar a superioridade, Deus me há de deparar uma criatura digna de mim.

E agora que me expliquei deixe-me ralhar-lhe um pouco. § Por que motivo dá tão facilmente ouvidos a uma calúnia contra mim? Você que me conhece há tanto devia ser a primeira a por de quarentena esses ditos sem senso comum. Por que o não fez faz?

Gastou você duas páginas para defender a Mariquinhas. Eu não a acuso; deploro-a. Pode ser que o noivo venha a ser um excelente marido, mas não creio que esteja na altura dela. E é neste sentido que eu a deploro.

A nossa divergência tem natural explicação. §Eu sou uma rapariga moça solteira, cheia de caraminholas, sonhos, ambições e poesia; você é já uma dona de casa, esposa tranquila e feliz, mãe de família dentro de pouco tempo; vês vê a coisa por outro prisma.

Será isto?

Parece que a companhia lírica não vem. A cidade está hoje muito alegre; andam bandas de música nas ruas; chegaram boas notícias do Paraguai. Naturalmente sairemos hoje; não tem saudades de cá?

Adeus.

Lembranças de todos a seu marido.

Raquel

VII

À mesma

Corte, 20 de Dezembro.

Tem razão; pareço ingrata. Há quase um mês que lhe não escrevo, apesar de ter recebido já duas cartas. §Seria longo explicar esta demora, e eu infelizmente não tenho tempo para tanto porque estou ${ }^{60}$ alguns dias com , porque estão aqui, alguns dias, as primas Alvarengas.

${ }^{60} J F$ sou 
Com Como que então, você confessa que apenas me quis experimentar? Eu logo vi que ninguém lhe poderia dizer semelhante coisa a respeito do Dr. Alberto.

O casamento da Mariquinhas está marcado para a véspera de Reis. Iremos assistir ao sacrifício. Desculpe-me, Luísa; bem sabes sabe como sou sarcástica, e às vezes... Desculpe-me, sim?

E todavia, quer saber uma coisa? §Mudei de opinião a certo respeito. $\S$ Hoje penso que antes o pai que o filho. Que espírito frívolo! que sujeito superficial e parvoalho tolo é o tal Alberto! O pai é grave e sabe ser amável; e é amável sem deixar de ser grave. Tem uma distinção própria, uma conversa animada, é engenhoso e sagaz.

Mil vezes o velho... para ela.

Pergunta-me o que farei eu no caso de nunca encontrar o ideal que procuro? § Já lhe disse: nesse caso fico solteira. §O casamento é uma grande coisa, é a flor dos estados, concordo; mas é mister que não seja um cativeiro, e cativeiro é tudo o que não exprime realiza as nossas aspirações íntimas.

Agradeço os seus conselhos, mas quer que lhe diga? Você fala como quem é feliz; parece-lhe que o casamento, quaisquer que sejam as condições, é um antegosto do paraíso.

Creio que nem sempre há de ser assim.

Verdade é que, dependendo as coisas das impressões de cada um, a Mariquinhas pode ser feliz, visto que o marido que escolheu parece falarlhe ao coração. § Não o nego; mas, nesse caso, continuo a lastimá-la, porque (repito) não compreendo a união de uma flor com uma carapuça. E não escrevo mais por não dizer mal da rapariga dela . Perdoe-me você estas tolices, e creia que sou sua amiga, agora e sempre. - Raquel

Raquel

VIII

À mesma.

Corte, 8 de Janeiro.

Casou-se a Mariquinhas. Festa íntima, mas brilhante. A noiva estava esplêndida, risonha, orgulhosa. O mesmo se pode dizer do noivo, que parecia ainda mais moço do que me parecera uma vez no teatro, a ponto de me fazer desconfiar da velhice dele. A cada instante cuidava que o homem tirava a máscara e confessava ser irmão do filho. 
Perguntar-me-á você se eu não tive inveja. ?

Confesso que sim.

Não sei bem se era inveja; confesso porém que suspirei quando vi a nossa formosa Mariquinhas com o seu véu e a sua grinalda de flores de laranja, derramar um olhar tão celeste em torno de si, feliz por se despedir deste mundo de futilidades como é a vida de uma moça solteira.

Suspirei, é verdade.

Se naquela mesma noite eu pudesse escrever o que senti, acredite você que teria uma página de literatura digna de figurar nos jornais.

Hoje tudo passou.

O que não passou, entretanto, porque existia antes e existirá sempre, porque nasceu comigo e comigo morrerá, é este sonho de uns amores que eu nunca vi na terra, uns amores que eu não posso exprimir, mas que devem existir visto que eu tenho a imagem deles no espírito e no coração.

Esse amor, minha querida Luísa, esse é o único verdadeiro, o único que merece a vida.

Mamãe, quando me vê aborrecida e devaneadora, costuma perguntarme se estou respirando as nuvens. Ela ignora talvez que exprime com essa imagem palavra o estado do meu espírito. § Pensar nestas coisas não é ir respirar as nuvens lá tão longe da terra?

Acabo de reler o que escrevi, e riscaria tudo se tivesse mais papel para escrever. Infelizmente não há tenho, isto é meia-noite, e esta carta há de seguir amanhã cedo. Risque pois o que aí fica escrito; não vale a pena guardar tolices.

Novidade não há que mereça a pena de mencionar. Esquecia-me dizerlhe que achei uma verdadeira qualidade no Dr. Alberto. Adivinha? Dança admiravelmente. Má língua! dirá você. E para que não diga mais nada, aqui me fico.

Raquel

IX

À mesma

Corte, 10 de Janeiro.

Isto é apenas um bilhetinho. Dou-lhe notícia de que vamos ter aqui uma representação familiar, como fazíamos no colégio. O Dr. Alberto foi encarregado de escrever a comédia; afiançam-me que há de sair boa. Representa comigo a Carlota. Os homens são o primo Abreu, o Juca e o Dr. Rodrigues. Ah! se você cá estivesse! 
D. Luísa a D. Raquel.

Juiz de Fora, 15 de Janeiro.

Meu marido quer ir à corte no fim do mês que vem. Ver-nos-emos enfim depois de alguns meses de separação. Escrevo apenas para lhe dar esta notícia que você há de estimar de certo.

E ao mesmo tempo o meu fim é preveni-la, a fim de que procure disfarçar na presença aquilo que me disfarça no papel.

Adeus.

Luísa

XI

D. Raquel a D. Luísa.

Corte, 20 de Janeiro.

O que é que eu disfarço no papel? Estou a meditar, a esquadrinhar, e nada descubro. Podia imaginar que você se refira refere ao assunto do Alberto; mas depois do que eu the escrevi seria demasiada insistência...

Explique-se.

Quanto à notícia que me diz dá de que vem cá, é para mim a sorte grande. Por mais que eu queira explicar no papel o prazer que sinto com isto, não posso. Não sei escrever; não me acodem as palavras próprias. O Dr. Alberto (o tal!) dizia outro dia que a língua humana é cabal para dizer o que se passa no espírito, mas incapaz de dizer o que vem do coração. E acrescentou esta sentença que é engenhosa, mas velha. Com os lábios fala a cabeça, com os olhos o coração.

Você porém adivinhará o que eu sinto e apressará a tua sua vinda. E o nenê? 
XII

À mesma.

Corte, 28 de Janeiro.

\footnotetext{
Estou muito zangada com você. A sua carta quase me fez chorar.

Pois quê! depois de lhe haver dito que nada há entre mim e esse Alberto, você insiste em suspeitar que sim.

É demais!

Que confiança lhe mereço eu então?

Alega você que eu falo muitas vezes nele; mas se isso fosse uma prova estava eu apaixonada por muita gente mais.

Vá, confesse que foi cruel comigo, e creia que sou sua amiga como sempre. Adeus.
}

Faz um calor insuportável; mas como eu abri a janela que dá para o jardim, estou a ver o céu "todo recamado de estrelas" como dizem os poetas, e o espetáculo compensa o calor. ${ }^{61}$ Que noite, minha Luísa! Gosto imensamente destes grandes silêncios, porque então ouço-me a mim mesma, e vivo mais em cinco minutos de solidão do que em vinte horas de bulício.

A Mariquinhas Rocha esteve esta noite cá em casa com o marido. Ambos parecem felizes, ela ainda mais do que ele, o que se me afigura completa inversão das leis naturais.

Não se admira de me ouvir falar em "leis naturais"? A ideia não é minha, é do próprio enteado, o Dr. Alberto. Conversamos os dois a respeito das boas e santas qualidades de Mariquinhas, e eu dizia o que ela foi sempre desde criança.

- Criança é ainda ela, observou ele sorrindo. Não posso chamar madrasta a uma criatura que parece antes minha irmã mais moça.

- Na idade, sim, tornei eu; mas na circunspecção e na compostura é positivamente mais velha que o senhor.

Ele sorriu, mas de um sorriso amarelo, e continuou:

- Meu pai é feliz; minha madrasta parece ainda mais feliz que meu pai. Não é isto uma inversão das leis naturais?

Critique se lhe parece, a opinião do filho; mas aproveito a ocasião para dizer que na sua última carta há duas linhas em que parece ter um resto de suspeita. Mande-me dizer como quer que a convença de que ele é para mim uma criatura igual a tantas outras?

Ande, confesse que é cruel comigo, e disponha-se a um sermão na primeira ocasião em que estivermos juntas.

Sabe quem eu vi hoje? Dou-lhe um doce se adivinhar. O Garcia, aquele Garcia que a nam... Não, não, paremos aqui

${ }^{61} \mathrm{HMN}$, 
D. Luísa a D. Raquel.

Juiz de Fora, 2310 de Fevereiro.

Não confesso nada; não fui cruel; tive uma suspeita , e francamente a expus.

Por que razão deixaríamos nós aquela franqueza do colégio, nós que fomos o tipo da amizade constante, da confiança ilimitada?

Pareceu-me que você estava de namoro com esse tal Alberto, e o disse como diria outra coisa, singela e discretamente.

Insiste em negar? Acredito que realmente nada há. Estou a ver que é alguma figura grotesca, e que primeiro lhe ofendi a vaidade que no coração.

Será assim?

Em todo caso, Raquel, nada de zangas entre nós; o que eu desejo é não perder a tua confiança como a tive sempre desde a meninice.

Meu marido manda-lhe muitas lembranças. Sabes que ele anda com ideias de se meter na política? Será uma desgraça para mim; mas que remédio?

Adeus.

Não confesso nada; não fui cruel. Tive uma suspeita e preferi dizê-la a guardá-la. A amizade manda isto mesmo. Por que razão deixaríamos nós aquela franqueza e confiança do tempo do colégio?

Acredito que realmente nada há, mas acredito também outra coisa. Estou a ver que é alguma figura grotesca, e que você foi antes ofendida na vaidade que no coração. Vá, confesse isso.

Sabe você uma coisa? Está me parecendo mais poeta do que era, mais romanesca, mais cheia de caraminholas. Bem sei que a idade explica muita coisa: mas há um limite, Raquel; não confunda o romance com a vida, ou viverá desgraçada...

... Um sermão! aí começava eu a fazer-lhe um sermão chocho e insulso, e sobretudo ineficaz. Venhamos a coisas mais de prosa. Meu marido quer entrar na política. Não se arrepia com esta palavra? Política e lua-de-mel, que duas coisas tão inimigas! Mas será o que Deus quiser. Lembranças dele e minhas a sua mamãe e a você. Até breve. 


\title{
XIV
}

\author{
D. Raquel a D. Luísa.
}

Corte, 715 de Fevereiro.

Ora bem, tudo está explicado; espero que nenhuma outra nuvem toldará o nosso céu.

Engana-se quando supões supõe que o Dr. Alberto é uma figura grotesca; já lhe disse que era é rapaz elegante; e até aquele ar compassado e escultural que eu lhe achava, até isso parece ter desaparecido desde que tem intimidade conosco.

Não é pois isso que nos afastaria um do outro.

É uma questão toda de simpatia e do coração.

Casar-se-ia você se seu marido lhe não falasse ao coração? Como hei de eu amar a quem me não faz palpitar nem devanear?

Estive quase a fazer aqui uma dissertação a respeito do amor; mas retraí a pena por me lembrar que seria ensinar o Padre Nosso ao vigário.

Seu marido quer entrar na política? E você tem medo? Eu também teria medo porque a política não se concilia com o amor, mas eu trataria de fazer com que se conciliassem...

Confesso, aqui para nós, eu tinha vontade de ser ministra... E você não sente o mesmo?

Dirá que eu estou brincando com as coisas do coração que são mais sérias que tudo mais. É verdade, mas isto mesmo prova que o meu esta livre, livre como a pena que me corre agora no papel produzindo uma letra que eu não sei se entenderás. Adeus

Não foi pois a minha vaidade que se ofendeu; não foi também o meu coração. Senti que você não me acreditasse, nada mais.

Eu podia fazer-lhe uma dissertação a respeito do amor; mas retraio a pena por me lembrar que iria ensinar o padre-nosso ao vigário.

Seu marido quer entrar na política? Vai você admirar-se da minha opinião a este respeito, que não parece opinião de uma devaneadora, como você me chama. Eu penso que a política para você tem uma onça de inconvenientes e uma libra de vantagens.

A política há de ser uma rival, mas pesadas as coisas antes essa que outra. Essa ao menos ocupa o espírito e a vida; mas deixa o coração livre e puro. Demais, eu nem sempre sou a cismadora que tens na cabeça; sinto um grãozinho de ambição comigo, a ambição de ser... ministra. Ri-se? Eu também me rio, o que prova que o meu espírito anda despreocupado e livre, livre como a pena que me corre agora no papel, produzindo uma letra que não sei se entenderás. Adeus. 
Que quer que lhe responda? Por que esta insistência? Era melhor poupar o meu acanhamento. Que lhe direi eu com a pena que já lhe não tenha dito com os olhos?

Esse amor que me confessa, esse amor que me afirma ser a sua existência toda, também eu o sinto grande, fervoroso, irresistível; mas será o senhor sincero? não estará zombando?

Diz-me que me ama há muito em silêncio; creio. Mas por que mo não confessou há mais tempo? Oh! eu tenho medo que isto seja para o senhor um passatempo, um capricho de sala, e nada mais. Será?

Seja franco; não lhe aproveitará muito zombar do coração de uma moça que merece, creio eu , alguma simpatia.

XV

O Dr. Alberto a Raquel

18 de fevereiro.

Perdoe-me a audácia; peço-lhe de joelhos uma resposta que os seus olhos teimam em me não dar. Não lhe digo no papel o que sinto; não o poderia exprimir cabalmente. Mas o seu espírito hade ter compreendido o que se passa no meu coração, hade ter lido no meu rosto aquilo que eu nunca me atreveria a dizer de viva voz.

Alberto 
Oh! não sabe como lhe agradeço a sua carta! Foi um raio de luz entre as sombras da minha incerteza. Sou amado? Não me ilude? Também sente esta paixão que me devora o peito, capaz de levar-me ao céu, capaz de levar-me ao inferno?

Tem razão quando me pergunta se o não percebera já nos seus olhos. É verdade que eu julguei ler neles a minha felicidade. Mas podia iludir-me; supus que a suprema felicidade não era tão pronta, e se me iludisse, não sei se viveria...

Por que razão duvida de mim? por que motivo receia que o meu amor seja um passatempo de sala? Que mortal haveria neste mundo que brincasse com a coroa de glória trazida à terra nas mãos de um anjo?

Não, Raquel... perdão se lhe chamo assim! Não, o meu amor é imenso, casto, sincero, como os verdadeiros amores.

Uma so palavra sua e podemos converter esta paixão no mais doce e calmo estado de bem-aventurança. Quer ser a minha esposa? Diga, reponda a essa palavra.

$\mathrm{XVI}$

D. Raquel a D. Luísa

21 de fevereiro.

Mamãe estava com disposições de ir visitá-la; mas eu infelizmente não me acho boa, e adiamos a viagem. Quando desempenha você a sua palavra vindo passar alguns dias na corte? Conversaríamos muito.

Raquel 
Esta resposta vai um pouco mais tarde do que eu quisera e devera ser.

Não foi culpa minha.

A resposta podia eu escrevê-la apenas recebi a sua carta. Três letras apenas.

Sim.

Se me ama como eu o amo, se deseja fazer-me feliz, dou-lhe a minha mão de esposa e o autorizo a pedi-la a meu pai.

Que mais quer?

Deixe porém que lhe ralhe um pouco. Por que razão não apareceu ontem apesar do meu silêncio? Cedo começa a deslembrar-me. Continuará assim quando for meu esposo?

Não se zangue; estou brincando.

Parece que mamãe já desconfiou disto.

Ontem estava eu lendo a sua carta, pela centésima vez, quando ela entrou no meu quarto e mal tive tempo de dobrar a carta e guardá-la.

Penso que ela deu um ar de riso.

Todavia nada me disse.

E eu estive quase a saltar-lhe ao pescoço e dizer-lhe todo o amor que tenho ao meu Alberto e a felicidade que espero dele.

Mas...

Talvez fosse apressada...

Dar-me-á ele essa felicidade ou está brincando comigo?

Escreva-me logo que possa.

Adeus.

XVII

À mesma

5 de março.

Não é carta; é apenas um bilhetinho. Não me dirá o que é o coração humano? Um logogrifo. Mistério! exclamará você ao ler estas linhas. Pois será. 
Fez você muito mal em me não escrever a dissertação a respeito do amor, não porque eu supunha que você não compreenda esse sentimento, nem porque eu o não compreenda também, mas porque do tom do escrito podia eu concluir alguma coisa.

Li não sei aonde que todo o escrito de um autor se ressente do último livro que ele leu.

É justamente o nosso caso.

As suas reflexões a respeito do amor haviam de ressentir-se do estado de seu coração.

O entusiasmo do estilo diria a natureza do sentimento.

Mas você parece que se esquivou de propósito, e nada me disse.

Quer emendar este erro?

Vejo o que me diz do Dr. Alberto. Compreendo que lhe não inspirasse nada, e retiro tudo o que escrevi. Quis fazer em tudo isto uma experiência, e cheguei a adquirir a certeza de que você falava a verdade. Ah! é tão difícil arrancá-la dos lábios de uma moça esperta!

Dou-lhe uma notícia triste.

Já não vamos à corte no fim deste mês. Meu marido tem necessidade de cá estar mais algum tempo; só no fim de abril faremos a nossa viagem.

Ande lá; nesse tempo quero achá-la presa... ao menos por simpatia

Adeus.

XVIII

Alberto a D. Raquel

8 de março.

Oh! não sabe como lhe agradeço a sua carta! Enfim veio! Foi um raio de luz entre as sombras da minha incerteza. Sou amado? Não me ilude? Também sente esta paixão que me devora o peito, capaz de levar-me ao céu, capaz de levar-me ao inferno?

Tem razão quando me pergunta se o não percebera já nos seus olhos. É verdade que eu julguei ler neles a minha felicidade. Mas podia iludir-me; supus que a suprema felicidade não era tão pronta, e se me iludisse, não sei se viveria...

Por que razão duvida de mim? por que motivo receia que o meu amor seja um passatempo de sala? Que mortal haveria neste mundo que brincasse com a coroa de glória trazida à terra nas mãos de um anjo?

Não, Raquel... perdão se lhe chamo assim! Não, o meu amor é imenso, casto, sincero, como os verdadeiros amores. 
Uma só palavra sua e podemos converter esta paixão no mais doce e delicioso estado de bem-aventurança. Quer ser minha esposa? Diga, responda essa palavra.

Alberto

A 13 deste mês escrevi-lhe uma carta de que ainda não obtive resposta.

Por quê?

Já me lembrou se estaria doente; mas creio que se assim fosse ter-me-iam mandado dizer.

Esta carta vai por mão própria; o portador não volta cá; mas sendo por mão própria tenho a certeza de que lhe será entregue.

E quero que me responda imediatamente.

Vá; um esforço.

Adeus.

\author{
XIX \\ D. Luísa a D. Raquel
}

Juiz de Fora, 10 de março.

O coração é um mar, sujeito à influência da lua e dos ventos. Serve-lhe esta definição? Pena foi que o bilhetinho não tivesse mais quatro linhas: saberia agora tudo. Ainda assim advinho alguma coisa; advinho que ama. 
Nada até hoje! Que é isso, Raquel?

O portador da minha carta anterior mandou-me dizer que lhe havia entregue em mão própria; não estava doente; por que razão este esquecimento?

Esta é a última; se me não escrever, acreditarei que outra amiga lhe merece mais, e que você esqueceu a confidente do colégio.

$\mathrm{XX}$

À mesma

Juiz de Fora, 17 de março.

A 10 deste mês escrevi-lhe uma carta que ainda não obteve resposta.

Por quê?

Já me lembrou se estaria doente; mas creio que se assim fosse ter-me-iam mandado dizer.

Esta carta vai por mão própria; o portador não volta cá; mas sendo por mão própria tenho certeza de que lhe será entregue. E quero que me responda imediatamente.

Vá; um esforço.

Adeus. 
Esquecer-me de você?

Está louca!

E que outra amiga haveria no mundo tão digna de estima e de confiança? Além disso que outra acharia eu que fosse tão harmônica comigo mesma?

Não a esqueci; não te esquecerei nunca.

É verdade que não lhe tenho escrito; mas essa falta tem outra causa, - causa sem valor nem importância, ando aborrecida e melancólica.

Por quê? perguntará você.

Sabe-se nunca por quê?

Tenho pensado muito na carta em que você me pediu que eu falasse do amor. Queria ver o que eu sentia, só com o exame do estilo. Era bem bom que me pedisse agora alguma dissertação para adivinhar o que tenho; eu não sei o que é.

Anda aqui agora uma companhia lírica de arribação; vem de Europa, vai para Buenos Aires. Tem vozes boas; é o nosso melhor divertimento.

Não sei se sabe que a nossa colega Adélia Ramos casou há três dias, com um oficial da marinha. E creio que breve casa outra.

Veja se resolve seu marido a vir cá antes do fim de abril. Em todo caso, diga-lhe que é um bárbaro, e adeus.

$\mathrm{XXI}$

D. Luísa a D. Raquel

Juiz de Fora, 24 de Março.

Nada até hoje! Que é isso, Raquel?

O portador da minha carta anterior mandou-me dizer que lhe havia entregue em mão própria; não estava doente; por que razão este esquecimento? Esta é a última; se me não escrever, acreditarei que outra amiga lhe merece mais, e que você esqueceu a confidente do colégio. 
Aceito as tuas explicações, meu Alberto; não imaginas como me fizeram bem ao coração?

Fora bem triste para mim começar a nossa vida conjugal com estas tristíssimas apreensões do ciúme. Porque é preciso que saibas que eu sou terna como uma rola, mas ciumenta como uma leoa. E se não conseguisse vencer-te qual seria o meu destino?

Alberto, eu bem vejo que me amas, e reconheço que tudo aquilo foi ilusão dos meus sentidos.

Obrigada!

Mamãe me perguntou ontem qual seria o nosso dia, e eu respondi que só tu podias marcá-lo.

Por que lho não dizes a ela?

Vai com esta carta uma florzinha da nossa chácara, colhida hoje de manhã, quando eu passeava pensando em ti.

E tu! pensaste em mim nessa mesma hora, ingrato?

Da conversa que tive ontem com a tua madrasta (mais moça que tu!) esqueceu-me dizer-te uma coisa essencial que te há de servir de lição espero eu.

A Mariquinhas é feliz, muito feliz, disse ela.

E se teu pai faz uma moça feliz, não dá com isto exemplo ao filho para que faça o mesmo?

Estarás disposto a observar esta lição eloquente?

Oh! jura que sim, porque tu és bom, tu és grande, tu sabes amar e és digno de ser amado!

Adeus!

D. Raquel a D. Luísa

Corte, 30 de Março.

Esquecer-me de você? Está louca! Onde acharia eu melhor amiga nem tão boa? Não tenho escrtio, é verdade, por mil razões, a qual mais justa, sendo a principal delas, ou antes a que as resume todas, uma razão... Não sei como the diga isto.

Amor?

Ah! Luísa, o mais puro e ardente que pode imaginar, e o mais inesperado também. Aquela devaneadora que você conhece, a que vive nas nuvens, viu 
lá mesmo das nuvens o esperado do seu coração, tal qual o sonhara um dia e desesperara de achar jamais.

Não lhe posso dizer mais nada, não sei. Tudo o que eu poderia escrever aqui estaria abaixo da realidade. Mas venha, venha, e talvez leia no meu rosto a felicidade que experimento, e no dele o sinal característico daquela superioridade que eu ambicionei sempre e tão rara é na terra.

Enfim, sou feliz!

Raquel

XXIII

D. Luísa a D. Raquel

Juiz de Fora, 25 de Março.

A sua carta de 18 veio muito a propósito, porque eu já estava zangada com você, e se dessa vez me não escrevesse podia contar que nunca mais nos falaríamos.

E perdíamos ambas creio eu.

Mas que explicação é essa que me dá! A tristeza, a melancolia, pode impedir que uma pessoa escreva às suas amigas; mas para isso é mister que a melancolia domine a alma, e você nunca se entristece mais de um quarto de hora.

Logo, a razão é outra.

Qual será?

Meu marido, a quem eu comuniquei as minhas dúvidas, pensa que você anda namorada. Eu disse-lhe que não, porque se assim fosse já eu o saberia. Entretanto nada explico em relação ao seu silêncio.

Quer que lhe peça uma dissertação para conhecer o estado da sua alma? Se você quissesse fazê-la não esperaria meu pedido.

Vou dizer o que penso.

Você sente um quê indefinível, uma inspiração vaga, um estado misterioso e inexplicável.

Dois remédios temos para isso.

$1^{\circ} \mathrm{Um}$ amor.

$2^{\circ}$ Um passeio a Juiz de Fora.

Escolha.

Vê se acha um amor; no caso de não encontrar nenhum digno de si, peça a seu pai que a traga para cá, e estou que estes ares a restabelecerão.

Esta é a minha receita; tenho fé de que se há de dar bem com ela.

Escreva-me. 
XXIII

D. Luísa a D. Raquel

Juiz de Fora, 8 de abril.

Chegou enfim uma carta, e chegou a tempo, porque eu já estava disposta a esquecer-me de você. Ainda assim não lhe perdoava, se não fosse a razão... Céus! que razão! Ama enfim? Achou o homem... quero dizer, o arcanjo que procurava a minha cismadora? Que figura tem? é bonito? é alto? é baixo? Vá, diga-me tudo.

Agora vejo que estive a pique de fazê-la perder a sua felicidade. Tanto the falei no tal Dr. Alberto, que, era bem possivel, como às vezes acontece, vir a namorar-se dele, e então quando o outro chegasse... era tarde.

E diga-me; será ele velho como o da Mariquinhas Rocha? Não se zangue, Raquel, mas o peixe morre pela boca, e era possível que você fosse castigada por ter falado dela. Pela minha parte, não acharia que dizer, uma vez que ele a amasse e fosse homem digno de casar com a minha Raquel. Em todo o caso, antes um moço.

Não me atrevo a pedir-lhe o retrato; mas meu marido pede-lho. Não se zangue, eu contei tudo e ele manda-lhe muitos parabéns. Os meus, irei eu mesma levá-los.

Deu-me você mais uma prova de boa amizade.

Agradeço muito a sua receita. É excelente.

Mas eu cuido que descobri a minha moléstia e a cura. Podia dizer-lhe aqui, mas tenho medo que você se zangue. Prometa não zangar-se?

Esta pergunta é cabida porque você está ficando muito irritável. Estive ameaçada de um rompimento de amizade por coisa de não lhe haver respondido. Eu sou muito exigente: mas tanto...

Ora, bem, prometa que se não há de zangar, e eu lhe direi o remédio e a cura.

Até lá, silêncio.

Adeus. 
XXIV

D. Raquel ao Dr. Alberto

10 de Abril.

Estou muito zangada por não teres vindo ontem; cedo começas a esquecer-me. Vem hoje ou eu fico zangada. Ao mesmo tempo quero que me tragas um retrato dos teus; é um segredo.

Ontem perdeste muito; esteve aqui a G... e naturalmente sentiu a tua falta. Sentes isso, não? Pobre da Raquel! Adeus.

Raquel

XXV

D. Luísa a D. Raquel

Juiz de Fora, 1 de Abril.

A data desta carta é terrível; mas entre nós não se olham datas.

Quer que lhe prometa que me não zango? Que singularidade! Zangar-me por quê? e como? e com que direito? Zango-me com a demora, isso sim; podia mandar dizer tudo e pedir perdão no fim, porque eu já agora 1 he ${ }^{62}$ mandava o perdão com um beijo e tudo estava acabado.

Vamos lá; franqueza e adeus.

\footnotetext{
${ }^{62} J F$ agora-lhe
} 


\section{$\mathrm{XXV}$}

\section{O Dr. Alberto a D. Raquel}

10 de Abril

Perdoa-me se não fui ontem lá; em compensação pensei muito em ti.

Teu pai pediu-me que eu fosse jantar hoje com a família; espera-me cedo.

Levarei nessa ocasião o meu retrato, sem saber para que é; mas espero que não será para coisa má.

Quanto à G... eu já não sei como te heide ${ }^{63}$ dizer que é uma delambida de quem não faço caso; se queres, limitar-me-ei a cumprimentá-la apenas. Que mais desejas?

Adeus, minha desconfiada. Crê que eu te amo muito, muito e muito, agora e sempre.

Teu

Alberto

XXVI

O Dr. Alberto a Raquel

2 de Abril

Perdoa-me se não fui ontem lá. Em compensação, pensei muito em ti.

Amanhã correm os primeiros banhos.

Teu pai pediu-me que eu lá jantasse; portanto espera-me às 2 horas e nessa ocasião levar-te-ei o meu retrato.

Por que razão mo pedes? Já não tens lá um? Tenho pensado muito nisto. Quererás mandar copiá-lo a óleo?

Até logo. Muitos e muitos beijos te envia o teu Alberto...

\footnotetext{
${ }^{63} \mathrm{HMN}$ heide de
} 


\section{XXVI}

D. Raquel a D. Luísa

17 de Abril.

Uma grande notícia! Fui ontem pedida a papai, e vou casar. Se soubesse como sou feliz!... Quisera que estivesse aqui para dar-lhe muitos e muitos beijos. Mas hade vir ao casamento, não? Se não vier, declaro que não caso.

Naturalmente adivinha que o retrato que vai dentro desta carta é o do meu noivo. Não é bonito? Que distinção! que inteligência! que espírito!... A alma, sobretudo, não creio que Deus mandasse a este mundo nenhuma outra que se the compare. Creio que eu não merecia tanto.

Venha depressa; o casamento há de ser em maio. Dê a notícia a seu marido.

Raquel

XXVII

D. Raquel a D. Luísa

Corte, 5 de Abril.

\footnotetext{
Não abra o pequeno embrulho que acompanha esta carta, antes de a ler.

Reduz-se a pouco o que tenho de dizer.

A minha enfermidade de que lhe falei há dias, a causa única do meu silêncio era e é o amor.

Amor não correspondido? perguntará você.

E imaginando que é assim fica logo a lastimar o meu pobre coração.

Não, Luísa.

Peço-lhe perdão se a enganei, se lhe falei de tristeza e tédio quando devia falar de entusiasmo e ventura.

Amo e sou amada.

Agora abra o embrulho que lhe mandei é o retrato dele. Não adivinha quem é? É (perdão!) é o Dr.Alberto.
} 
$X X V I I$

D. Luísa a D. Raquel

Juiz de Fora, 22 de Abril.

Que cabeça! disse tudo menos o nome do noivo!

Luísa

XXVIII

D. Luísa a D. Raquel

Juiz de Fora, 8 de Abril.

Muitos parabéns e muitos perdões.

Perdoo-lhe (e custa-me!) o silêncio, a reserva com que se houve até hoje comigo neste assunto em que eu me interesso porque se trata da minha melhor amiga.

Por que razão tamanha reserva?

O noivo é bonito; não seria essa a causa.

Em suma, agora tudo acabou. Resta saber quando é o dia da festa porque eu desejo comparecer se me der licença. Mande dizer quanto antes.

E adeus.

XXVIII

D. Raquel a D. Luísa

Corte, 27 de abril.

Tem razão; sou uma cabeça no ar. Mas a felicidade explica ou desculpa tudo. O meu noivo é o Dr. Alberto. 
XXIX

D. Raquel a D. Luísa

Corte, 14 de Abril.

O casamento é no dia 14 do mês que vem. Você devia ser convidada por força, isto porque (se te não opões) deves ser a minha madrinha.

Quer?

Quanto à razão do meu silêncio foram duas.

A primeira encontrá-la-ás nas cartas minhas que lá tens. Tanto mal disse de Alberto que me envergonhava de confessar o erro quando reconheci que as suas qualidades eram superiores.

Receei que se risse de mim.

Costumam dizer que as mulheres vêm a amar aquilo que mais desdenham. Eu tive medo de que me lançasse em rosto esta versatilidade.

A segunda razao foi esta:

Não quis anunciar uma felicidade que poderia esvair-se. Ou por outra: não cantei vitória antes de ter o pássaro na mão.

E o pássaro está na mão.

Nunca vi amor mais submisso, mais completo, mais absoluto do que o dele. Se eu não for feliz, a culpa não será de Alberto.

Nem minha.

Adeus.

\section{XXIX}

\section{Luísa a D. Raquel}

Juiz de Fora, 1으 de maio.

!!

Luísa 


\section{Capítulo 4}

\section{Análise do percurso genético}

\subsection{O processo de omissão}

Analisando o movimento geral de omissão durante a reescrita dos contos, podemos dizer que na maioria dos trechos excluídos, personagens, usos e costumes da época eram ridicularizados. Essa ridicularização, por vezes, resultava em uma caracterização cômica do personagem e/ou situação própria do narrar folhetinesco e que talvez não fizesse tanto sentido quando o conto era publicado em livro.

Esse processo de omissão pode ser notado muito claramente no conto "A parasita azul", no qual várias críticas e deboches direcionados ao padre Maciel, ao moço Camilo, ao major Brás, à Igreja, ao casamento e à política são, sem maiores explicações, suprimidos na versão em livro.

Um bom exemplo é a omissão do trecho, logo no início do conto, em que ficamos sabendo que o padre Maciel retirou partes da carta de Camilo ao pai para colocá-las em seu sermão (p.24) ou quando, no capítulo IV, o narrador nos informa que a conjectura do padre era melhor do que as outras "unicamente pela razão de ser sua" (p.41). No mesmo capítulo, também é retirado o trecho que satiriza a maneira como o padre (re)formulava os seus sermões (p.44). Com a retirada desses períodos, percebemos um distanciamento do julgamento do narrador e uma tentativa de minimizar a ridicularização explícita do padre.

As atenuações à crítica política também podem ser vistas pelas várias omissões que acontecem no capítulo III, por exemplo, quando deixamos de ser informados, na versão em livro, de que o Dr. Matos tinha política oposta à do comendador, mas que isso "não impedia que fossem íntimos amigos" (p.33). Em outro trecho, quando Camilo pergunta ao pai de que lhe serve a política, há omissão do período "Dá lugar às posições" (p.34). 
Durante o jantar do capítulo $\mathrm{V}$, também há a omissão do trecho em que os participantes falavam mal dos adversários políticos, acreditando que esses também já haviam falado mal deles (p.46).

$O$ discurso vazio do major Brás, no capítulo $V$, continua sendo criticado em livro, mas há a omissão de um trecho em que o major se ocupa em "rememorar as belas palavras que acabava de proferir" (p.47). Essa omissão ameniza um pouco a ironia com que o narrador tratava e criticava o personagem.

No capítulo IV, há a supressão de um longo trecho sobre a festa do Divino (p.39) que pode ser entendido como uma alegoria ao Império brasileiro (onde o imperador era uma criança e o império é transformado em palanque). Ao retirar esse trecho, percebemos que Machado procura deixar de se envolver com essa polêmica questão. Além disso, nessa mesma parte, é possível sentir certa nostalgia, um apego às tradições e aos costumes antigos, um saudosismo exacerbado, que não condizem muito com o Machado que conhecemos. Um pouco mais adiante, no mesmo capítulo, há a omissão do adjetivo imperial, quando se fala sobre a grandeza (irônica, claro) do tenente-coronel (p.40). Novamente, essa supressão deixa de dialogar com o tema Império e a crítica torna-se mais sutil.

No capítulo III, ocorre uma omissão muito significativa, quando o narrador decide "abrir o jogo" e explicar exatamente o que se passava na mente de Leandro Soares (p.37). O trecho omitido iniciava-se assim: "Nada há porém que possa escapar a um autor que timbra em trazer instruídos os seus leitores". A retirada desse trecho ilustra claramente o que havíamos pontuado anteriormente; a procura pelo distanciamento do narrador, a diminuição do tom pedagógico e explicativo (próprio do narrar folhetinesco) que desejava detalhar tudo o que acontecia na história. Com a omissão desse trecho, já podemos perceber o narrador machadiano que procurar deixar cada vez mais encoberto o que quer dizer, que brinca com a ignorância do seu leitor e faz questão de ser o menos explicativo possível.

Entretanto, na primeira linha do capítulo VI, o narrador volta a repetir a estrutura que havia sido suprimida e afirma: "Não há mistérios para um autor que sabe investigar todos os recantos do coração"(p.48) e estabelece um diálogo com o leitor explicando os motivos do amor de Isabel. O que pode parecer uma contradição apenas confirma a hipótese lançada anteriormente de um escritor em formação, que ainda não está em sua "maturidade" plena e que oscila entre os diferentes tipos de registros.

Ao fim do capítulo $V$, temos a retirada de um trecho em que o narrador dialogava com o leitor de folhetim e se desculpava pelo termo usado (cama em vez de leito da dor) e ainda justificava: "São descuidos que o tempo emendará" (p.48). No entanto, na versão em livro, apesar de ter tido tempo 
de emendar esse "deslize", ele não o fez, o que assinala um tom de rebeldia e afirmação própria de um autor que irá usar o vocábulo que lhe convier sem procurar atender ao gosto de seus leitores por um estilo mais recatado.

Na cena onde vemos Camilo se lançando aos jornais, há a omissão da expressão popular "como gato a bofes" (p.59), o que atenua o tom cômico e coloquial da cena.

No conto "As bodas de Luís Duarte" / "As bodas do Dr. Duarte", vários trechos que ridicularizavam os personagens também são retirados. Dois parágrafos seguidos que trazem uma descrição cômica de D. Margarida e sua sobrinha D. Augusta são completamente excluídos (p.64), assim como a descrição engraçadíssima de Luís Duarte e seu estrabismo em um olho só (p.66).

A revelação do caráter supérfluo do rapaz Rodrigo (p.67), a comicidade da exposição das ceroulas de Justiniano Vilela (p.67) ou a falta de modos dele à mesa (p.71), o julgamento do narrador sobre o discurso "oco" de José Lemos (p.72), e a "batalha" do jantar (p.70), são todos trechos suprimidos e/ou amenizados na versão em livro.

Podemos perceber, como já foi salientado, uma atenuação dos traços cômicos na passagem do Jornal para o livro. Era comum que os leitores buscassem nos folhetins uma leitura leve e fácil, para entretenimento e diversão, muito condizente com o tom cômico, e essa alteração de uma versão para outra nos faz pensar mais uma vez em um Machado consciente do público para o qual se dirigia.

Outro ponto interessante é que, na primeira versão, Duarte, na maioria das vezes, aparece referido por meio de um título, seja de doutor ou de bacharel, e o nome dele só é revelado no meio da história. Quando revê e prepara a segunda versão, Machado retira todos os títulos do rapaz e opta por usar o nome Luís Duarte desde o início do conto. Isso pode ser visto na própria mudança de título que na primeira versão era "As bodas do Dr. Duarte" e na segunda ficou "As bodas de Luís Duarte".

Na p. 66, quando é feita a descrição de Luís Duarte e do seu penteado "apartado no centro da cabeça", há a omissão do trecho "como o atual príncipe de Metternich". Embora não tenha sido localizada nenhuma imagem do príncipe Richard von Metternich (1829-1895) com "o cabelo apartado no centro da cabeça", deve ser ele a personagem a quem se refere o narrador do conto. É possível conjecturar que nos jornais da época circulassem fotografias do príncipe e diplomata com cerca de 40 anos, usando esse penteado. Podemos perceber, mais uma vez, o diálogo do texto com o meio que o cercava, ao pensarmos que esse tipo de descrição fazia parte do repertório do Jornal das Famílias e, na passagem para o livro, já não fazia mais sentido ter esse tipo de comentário. 
Em "Ernesto de tal" também não faltam referências satíricas que foram suprimidas na reescrita do conto, principalmente o longo monólogo fatídico do moço onde fica realçado o melodrama folhetinesco e a incapacidade de Ernesto em tomar resoluções ou enxergar a realidade (p.85-6). Os poucos (e irônicos) elogios que apareciam na $1^{\mathrm{a}}$ versão e ressaltavam o "espírito de ordem" de Ernesto (p.76) também são omitidos.

Na p. 84, na cena em que o filho de Vieira está à janela e os dois namorados conversavam, há a retirada do trecho em que o garoto desce "da cadeira a que trepara". Com essa exclusão, percebemos uma diminuição do tom coloquial da cena.

No conto "Ponto de vista" acontece um movimento de exclusão muito importante no início do texto. Ao reescrever o conto, Machado retira todo o Prefácio que introduzia a história e explicava a origem das cartas que o leitor teria em mãos (p.122). Assim como o prefácio excluído, foi eliminado outro elemento que daria veracidade às cartas e atestaria o tom informal de conversa entre amigas; a nota da carta V, em que aparece a informação de que o resto da carta fora suprimido por se tratar de modas (p.126).

O prefácio dava à narrativa um certo tom verídico, isentando o narrador de qualquer participação com o que iria ser contado, já que ele prometia apenas apresentar as cartas que lhe chegaram à mão sem modificá-las em nada. Como lembra Azevedo (2012: 174), ao retirar esse prefácio, também desaparece "o narrador preocupado em tranquilizar o leitor - como acontecia nos contos morais - quanto à 'veracidade' da história que vai ser contada."

O fragmento em que as intenções de Alberto são colocadas em dúvida por um possível interesse financeiro pela riqueza da moça é retirado na versão em livro (p.125). Raquel afirmava que conhecia a vida e podia se livrar dos rapazes interesseiros com facilidade. Mais uma vez, essa frase explica a situação mais detalhadamente ao leitor, movimento que Machado parece querer evitar na versão em livro. Trechos de extremo romantismo e idealização também são excluídos de uma versão para outra, assim como o final moralizante que completava o título do conto no Jornal ("Quem desdenha"): "as mulheres vêm a amar aquilo que mais desdenham" (p.148).

Em "O relógio de ouro" encontramos trechos retirados que não interessam, como o próprio narrador diz, à história. Nesse conto também é excluída a cena em que o marido ameaça a esposa com um revólver, resultando em uma diminuição do tom melodramático, que combinava mais com a publicação em folhetim.

Nesse conto também é excluída a informação de que Luís Negreiros gostava de charadas nos jornais de moda, e, na segunda versão, temos apenas que Negreiros "gostava de charadas nas folhinhas ou nos jornais" 
(p.115). Isso parece indicar um desejo de distanciamento do veículo de publicação da primeira versão (folhetim). Essa referência, naquele contexto, dialogava com os leitores do Jornal das Famílias (no qual a moda era assunto importante), e muitos desses leitores, assim com Negreiros, gostavam desse tipo de passatempo.

Parece haver também, nos parágrafos iniciais de "Aurora sem dia", um distanciamento do escritor que evita discorrer sobre lugares que frequentava ou sobre os processos e meios de publicação nos quais estava envolvido. Na primeira versão, há uma explicação nostálgica de como era esse processo que foi completamente suprimida na versão em livro. No Jornal das Famílias tínhamos a recordação da publicação do volume de poesias de Casimiro de Abreu (possivelmente As primaveras, 1859) que, muito provavelmente, era conhecido pelos leitores do Jornal, já que foi um sucesso instantâneo, agradando aos leitores mais românticos e melancólicos, tais como Luís Tinoco.

Havia também a rememoração das reuniões na casa de Paula Brito (situação vivenciada por Machado e da qual ele participava com entusiasmo) e ainda uma espécie de confissão calorosa sobre o prazer maternal de ver "impressas as primeiras produções" (p.96). Vemos claramente que o trecho é repleto de clichês românticos e de ironia, mas não podemos deixar de pensar se essas palavras não serviriam para explicar o que sentiu o próprio jovem Machado ao dar início à sua carreira literária.

Em "Aurora sem dia", há várias omissões de críticas relativas à política também. Isso pode ser confirmado ao analisarmos, por exemplo, os trechos em que Anastácio afirma que só lia os jornais quando era empregado efetivo para falar mal dos adversários políticos do seu chefe (p.97).

Podemos concluir que muitos dos trechos excluídos eram supérfluos à narrativa e, de alguma forma, explicitavam a posição do narrador, a partir do seu julgamento ou da satirização das práticas sociais. Ao reescrever os contos para o livro, Machado parece suprimir esses trechos para aprofundar a ironia, tornando-a mais complexa e não tão imediata, fazendo com que o leitor tente perceber e julgar por si mesmo, sem ter, a todo o momento, um narrador que encaminhe o rumo dos seus pensamentos e aponte para qual direção olhar.

\subsection{O processo de adição}

Embora constatemos que grande parte das modificações caminham para a concisão, há também, na reescrita desses contos, várias adições. Uma das mais significativas se dá no conto "O relógio de ouro", no qual, du- 
rante a cena do jantar, o narrador traz um histórico (que não aparecia na versão do Jornal) sobre a vida de Luís Negreiros e faz um alerta sobre o passado maculado dele e a desconfiança com que o sogro o tratara (p.119). Nesse momento, somos informados de que Negreiros possuía um caráter duvidoso e fora um "leão impetuoso" noutros tempos.

Essa passagem é muito interessante, porque, apesar de parecer ir de encontro com o que afirmamos anteriormente (omissão do julgamento do narrador), a prosa é elaborada de tal maneira que essa informação comprometedora sobre Negreiros passa despercebida por nós leitores, e só durante a releitura percebemos o quanto fomos coniventes com a situação e confiamos cegamente em Luís Negreiros, mesmo tendo evidências de seu caráter infiel.

Acreditamos que esse trecho, apesar de trazer uma informação nova, não resolve os problemas de interpretação para o leitor nem deixa de exigir dele uma reflexão; ao contrário, serve para evidenciar ainda mais a nossa aderência ao discurso do narrador sem ao menos considerarmos as informações dadas por ele que possam ser contrárias às nossas expectativas.

Em "Aurora sem dia" há várias adições interessantes que ironizam ainda mais o caráter romanesco de Luís Tinoco. Como exemplo, podemos lembrar do trecho adicionado à segunda versão que nos informa sobre a limitação intelectual do poeta que, ao escrever um exemplar de cada gênero (ode, elegia, necrológio etc.), ia criando novos textos apenas modificando os primeiros (p.102).

Há também a adição do trecho em que o poeta apaixonado por sua Laura (que se chamava Inocência), ao ser vencido por um rival mais "conjugal", publica no seu Caramanchão Literário uma "extensa e chorosa elegia" e, relendo os seus versos sem cessar, acaba até por esquecer a "perfídia que os inspirou"(p.106).

Na versão em livro ficamos sabendo também que Luís Tinoco não costumava fazer uma leitura cuidadosa; ele gostava é de frases feitas, sonoras. Tudo o que fosse "reflexão, observação, análise parecia-lhe árido, e ele corria depressa por elas" (p.108).

Há ainda a adição de um longo trecho repleto de clichês e ironia sobre a candidatura política de Tinoco (p.111-2) onde vemos o poeta delirante sobre o futuro grandioso que o esperava.

No processo de adição durante a reescrita do conto "Aurora sem dia", podemos perceber, enfim, que o narrador torna-se menos complacente com Luís Tinoco e trata-o com mais dureza e severidade, além de procurar acentuar o caráter fútil e superficial de Tinoco.

Na carta XII do conto "Ponto de vista", temos a adição de um trecho que explicita ainda mais o caráter romântico e sonhador de Raquel que 
vive mais "em cinco minutos de solidão do que em vinte horas de bulício"(p.131).

Há também a adição de uma nova informação e ficamos sabendo da conversa que Raquel teve com Alberto sobre a felicidade dos recém-casados (Mariquinhas e o pai de Alberto, ela demonstrando mais felicidade do que ele), e a completa inversão das "leis naturais" que se configurava nesse caso (p.131).

Na carta seguinte, Luísa acrescenta, na segunda versão, a observação de que a amiga está mais romanesca, com a cabeça cheia de caraminholas e faz a seguinte advertência: "não confunda o romance com a vida, ou viverá desgraçada" (p.132).

Por que será que a advertência de Luísa não aparece na primeira versão do conto publicada no Jornal? Podemos pensar na hipótese de que esse "sermão" não combinava com o perfil das leitoras acostumadas com romances românticos ou que seria uma "lição" dispensável, algo que não fazia parte do que as leitoras gostariam de reconhecer nos seus momentos de lazer.

Em "Ernesto de tal", no capítulo V, quando os dois rivais estão conversando, há a adição de um trecho em que o moço de nariz comprido reflete mais se deveria acreditar tão cegamente em Ernesto e julgar a moça tão precipitadamente. Várias provas são necessárias (como a carta, a descrição dos gestos etc.) para ele, finalmente, acreditar que havia sido enganado (p.89-90).

Na primeira versão, a relação de ambos se torna mais amistosa, já que o próprio guarda-livros dá o braço a Ernesto para ir ao Passeio Público. O desfecho da situação é muito mais rápido e imediato, não há muitas reflexões nem dúvidas, como acontece na versão em livro, na qual o rapaz de nariz comprido demora mais a acreditar em Ernesto.

Do mesmo modo, no desfecho do conto (p.94-95), quando Ernesto volta à casa de Rosina e ela pede-lhe perdão, confessando ter escrito a carta ao rival (mas por culpa de Ernesto), há uma adição interessante. Na primeira versão, Ernesto logo acredita na moça e considera-se culpado. Na versão em livro, Ernesto ainda desconfia um pouco de Rosina e a faz sofrer por um instante antes de aceitá-la novamente.

O narrador também descreve o raciocínio tolo de Ernesto ao explicar o porquê de ele acreditar na moça e perdoá-la. Assim ficamos sabendo que Ernesto conclui que, como não houve negação sobre as cartas por parte da moça, ela só poderia estar sendo sincera. Há ainda a adição de detalhes sobre o casamento dos dois, como a igreja em que foi celebrado e o estado de espírito dos noivos.

Os trechos acrescentados de uma versão para outra não são tão numero- 
O processo de substituição

sos quanto os excluídos, mas alguns são tão significativos quanto aqueles e também ilustram o trabalho de reescrita empreendido pelo autor.

\subsection{O processo de substituição}

No conto "Ponto de vista" temos uma substituição logo no início do texto. Na versão do Jornal das Famílias, o título era "Quem desdenha" e foi trocado posteriormente para "Ponto de vista". O título da $1^{a}$ versão já dava o tom moralizante da história que se completa com o ditado popular (Quem desdenha quer comprar) e com o desenrolar das ações de Raquel. Esse tom pedagógico e salutar (que parece ser evitado na reescrita dos contos em geral) é amenizado pela alteração do título.

Nas cartas trocadas por Raquel e Luísa há uma oscilação dos pronomes usados para marcar a conversação das amigas. Usa-se tanto tu quanto você. Essa variação fica ainda mais evidente na segunda versão do conto quando podemos notar que foram feitas várias substituições da forma de tratamento da $2^{\mathrm{a}}(t u)$ para a $3^{\mathrm{a}}$ pessoa $($ você) .

Alguns estudos como Lopes \& Machado (2005) apontam justamente como essa mudança se deu em cartas do século XIX, especialmente, como as mulheres teriam iniciado a mudança do uso da forma $t u$ para você.

É importante lembrar que no século XIX, o emprego da forma pronominal tu era indicativo do caráter íntimo da relação entre os envolvidos. Por outro lado, como apontam Silva \& Barcia (2002:7), o uso do você, "uma variante em vias de gramaticalização, ocorre preferencialmente nas relações íntimas de família, marcadas, ainda, por uma relação assimétrica (superiorinferior)". Não é o que parece acontecer no caso do conto. Tanto Luísa quanto Raquel flutuam entre o uso de ambas as formas, sem aparente relação hierárquica.

Lopes (2009) lembra que o uso de você não era completamente estável, pois aparecia também "como uma estratégia de prestígio usada pela elite brasileira da época". Ainda segundo a autora, uma possível razão para o uso mais frequente de você em cartas escritas por mulheres é que essa forma seria mais distanciada, indireta, atenuante e menos invasiva do que otu.

Essa variação, como pudemos constatar, aparece não só na ficção, como no caso do conto, mas fazia parte do universo real e mais imediato das pessoas naquela época.

A carta XV de "Ponto de vista", embora diferente em cada versão, traz o momento de revelação (p.134). No Jornal, é quando Raquel confessa a Alberto que também o ama. Em Histórias da meia-noite temos uma inversão 
e é Alberto quem se declara para Raquel. A partir desse ponto, a ordem das cartas e o conteúdo de algumas delas são sempre diferentes em cada versão, embora tenhamos, nos dois casos, o total de 29 correspondências. No Jornal, o diálogo entre Alberto e Raquel é mais desenvolvido e temos acesso a cartas que não aparecem na versão em livro. Em algumas cartas vemos apenas a mudança da ordem em que aparecem enquanto o conteúdo praticamente não é alterado (XVI (JF), XVIII (HMN) / XIX (JF), XX(HMN, por exemplo).

Por fim, a última carta de Luísa, em vez de perdão e votos de felicidade (p.147), como acontece na $1^{\mathrm{a}}$ versão, é substituída por pontos de exclamação na $2^{\mathrm{a}}$ versão (p.148). É notável a semelhança de procedimento que acontece aqui e em "O relógio de ouro". Em ambos os casos, temos uma suspensão das explicações e um final abrupto diferente do que acontecia nas respectivas versões em folhetim. Com as várias substituições que aparecem nesse conto, percebemos, além da reorganização do enredo, a diminuição do tom romântico e pedagógico que aparecia no Jornal.

Em "Ernesto de tal", há algumas substituições extensas onde, muitas vezes, o conteúdo do trecho não se altera, mas a forma de composição sim. Por exemplo, nas p.85-86, temos um trecho em que acompanhamos o que se passa na cabeça de Ernesto e o vemos tentar resolver as suas inquietações e dúvidas. Na versão em livro, esse trecho é substituído por outro, bem mais elaborado e com pinceladas de ironia e humorismo machadianos. $\mathrm{O}$ conteúdo é praticamente o mesmo, mas a forma de prepará-lo é bem mais requintada. Vejamos uma parte desses trechos:

\section{No Jornal das Famílias:}

Esta pergunta foi o ponto de partida de uma série de conjecturas, todas tétricas, e algumas ensanguentadas. Ernesto passeou cerca de uma hora na sala da casa em que morava fazendo a si mesmo uma enfiada de perguntas que pareciam não acabar nunca mais.

Ama a outro?

Esfria comigo?

Que será o outro?

Será ele?

Ou terceiro?

Ou quarto?

Devo matá-lo?

Devo desprezá-lo? 
Ou simplesmente expulsá-lo?

Não conseguiu adotar nenhuma destas resoluções, nem acertou com qual das perguntas exprimia a realidade da situação.

Jorge, seu companheiro de casa, chegou a tempo de lhe dar dois conselhos. Ele precisava de um; tinha dois à escolha.

No livro Histórias da meia-noite:

Como por via de regra, é da nossa miserável condição que o amor-próprio domine o simples amor, apenas aquela suspeita lhe pareceu provável, apoderou-se dele uma feroz indignação, e duvido que nenhum quinto ato de melodrama ostente maior soma de sangue derramado do que ele verteu na fantasia. $\mathrm{Na}$ fantasia, apenas, compassiva leitora, não só porque ele era incapaz de fazer mal a um seu semelhante, mas sobretudo porque repugnava à sua natureza achar uma resolução qualquer. Por esse motivo, depois de muito e longo cogitar, confiou todos os seus pesares e suspeitas ao companheiro de casa e pediu-lhe um conselho; Jorge deu-lhe dois.

Enquanto que na primeira versão o monólogo de Ernesto e a possibilidade de Rosina ter vários namorados provocam um efeito cômico no leitor, na segunda versão, há um desenvolvimento psicológico um pouco mais profundo da personagem.

Na versão do livro, o narrador, fazendo uso do humorismo, do pessimismo e da ironia, também se inclui na "nossa miserável condição", para, logo em seguida, ressaltar a incapacidade de Ernesto em tomar alguma decisão.

Do mesmo modo, o início do capítulo $\mathrm{V}$ também é reformulado e, na segunda versão, o caráter pífio de Ernesto e sua " frouxidão de ânimo" ficam ainda mais evidenciados (p.87).

Na versão de "O relógio de ouro" publicada no Jornal das Famílias, depois da revelação do verdadeiro dono do relógio, o autor acrescenta uma espécie de prólogo, onde explica o desenrolar da história; a paz familiar é mantida, o marido perdoado e a amante esquecida (p.121-2).

Já na versão do conto publicada em livro, o narrador suspende o desfecho do caso e subverte toda a expectativa do leitor, provocando uma reflexão sobre nossos próprios preconceitos e sobre o julgamento antecipado que comumente dispensamos a Clara.

Com a substituição do epílogo apaziguador e explicativo (de certa forma, necessário para a versão em folhetim) pelo final inesperado e abrupto 
("Assim acabou a história do relógio de ouro", p. 122), percebemos o amadurecimento de um modo de narrar machadiano que consiste em retirar cada vez mais os elementos que deem ou possam dar respostas prontas, forçando-nos a interpretar ou buscar explicações por nós mesmos.

Ainda em "O relógio de ouro", a troca das formas de tratamento de "bebê" por "nhonhô" e "Zeferina" por "Iaiá" (p.121), na versão em livro, ressalta e reforça a alusão à escravidão já contida no nome de Luís Negreiros.

No conto "A parasita azul", há uma substituição, logo na primeira linha, que indica uma procura por maior precisão com a troca de "Há coisa de alguns anos" por "Há cerca de dezesseis anos" (p.22).

No segundo parágrafo do capítulo IV de "A parasita azul" (p.39), há uma substituição vocabular sobre a qual nos deteremos um pouco. Nela, vemos a troca da palavra sofreguidão por curiosidade. Como o trecho discorre sobre as festas tradicionais, com essa substituição, há uma atenuação do aspecto positivo dessas festas, que antes seriam estudadas com avidez e que agora, são vistas apenas como curiosidade, sem sentimentalismo.

Ao longo de todo esse capítulo IV, há várias substituições do termo imperador por tenente-coronel. Isso parece indicar, como apontamos anteriormente, um afastamento de uma posição tão explícita que parodiava a relação da narrativa com o próprio Império brasileiro. É bem verdade que o substantivo imperador ainda é usado durante o capítulo, mas não gratuitamente. Ele só é usado para indicar a função ou posição do personagem e quando pode ser substituído por tenente-coronel sem prejuízo de sentido, ele assim o é. Por exemplo, na maioria das vezes, imperador é acompanhado pelo locução adjetiva "do divino" ou "do Espírito Santo", onde não caberia tenente-coronel. Quando não é o caso, temos sempre um adjetivo (festivo, vistoso, estreante) acompanhando "imperador".

No final do capítulo IV, há uma substituição do nome do Dr. Matos, que na primeira versão, somente nesse trecho (p.45), fora chamado de Dr. Batista. Acreditamos que esse movimento seja um indício de correção autoral do nome do personagem. A substituição de "a gente é vítima" por "somos vítima", na p.51, ressalta também uma atenuação do tom coloquial. Provavelmente, por conta da construção anterior "a gente", não foi feita a correta concordância na segunda versão, que deveria ser "somos vítimas".

No início de "Aurora sem dia" (p.96), há uma substituição muito interessante. Comparemos os dois trechos:

No Jornal das Famílias: "Nenhuma mãe contempla o filho recém-nascido com mais amor, do que um poeta estreante lê e relê a primeira produção impressa. Assegura-se logo que todos os leitores do jornal estão fazendo o mesmo, e que o nome do jovem autor anda na boca de todos como uma 
grande revelação literária".

Em Histórias da meia-noite: "Nenhuma mãe contemplou o filho recémnascido com mais amor do que o rapaz leu e releu a produção poética, aliás decorada desde a véspera. Afigurou-se-lhe que todos os leitores do Correio Mercantil estavam fazendo o mesmo; e que cada um admirava a recente revelação literária, indagando de quem seria esse nome até então desconhecido".

Ao usar pronomes indefinidos antes dos sujeitos (nenhuma mãe, um poeta) no primeiro trecho, seguido por um sujeito indeterminado (assegurase) cria-se um efeito de inclusão, identificação desse narrador (e dos leitores) com a história de Tinoco, o que dá margem para uma sugestão de que o próprio Machado poderia ter experimentado esses sentimentos, como dissemos anteriormente. Em oposição, no livro, há um distanciamento criado por um sujeito claramente marcado (o rapaz, Luís Tinoco) e uma delimitação do público (os leitores do Correio Mercantil) que garantem um efeito satírico, ridicularizando e expondo Luís Tinoco.

Seguindo essa mesma linha interpretativa, é notável a mudança que se opera no foco narrativo do conto, da primeira para a terceira pessoa, em que o Dr. Lemos passa de narrador a personagem da história. A mudança de foco narrativo também é importante para o desfecho do conto; na primeira versão, havia um final apaziguador em que vemos Luís Tinoco rico e feliz, conformado com a sua incapacidade intelectual, tudo isso chancelado pelo discurso do Dr. Lemos que garantia a "verdade" da história.

Havia ainda a frase conclusiva "Foi uma aurora sem dia" (p.114), que, de certa forma, dava um tom de lamentação ao fim que teve Tinoco. Sobre a retirada desse trecho final, podemos pensar também na hipótese de Minchillo (2010 : 102) de que essa supressão "talvez tenha sido uma estratégia de Machado, em 1873, de justamente fugir da sentença moralizante. "

No desfecho da primeira versão, como lembra Minchillo (2010), há um final moralizante, compatível com os padrões românticos em voga. Já o uso de primeira pessoa na versão do Jornal das Famílias não dá margens para imprecisões ou para outro julgamento que não seja o do Dr. Lemos; o final é resolvido sem grandes tensões, já que Luís Tinoco está rico e bem casado, feliz com a vida que leva.

Quando Machado reescreve o conto e muda o foco narrativo para a terceira pessoa, esse final apaziguador deixa de existir, já que o que era certo e seguro nas palavras do Dr. Lemos, passa para o discurso de Luís Tinoco, o qual, como podemos observar durante todo o conto, sempre teve um visão não muito realista de si mesmo.

Como já foi observado, Luís Tinoco é tratado com mais severidade pelo narrador em diversos momentos na segunda versão. Uma substituição 
interessante acontece no trecho em que o Doutor Lemos, ao conversar com o advogado, na primeira versão, faz boas (apesar de irônicas) recomendações a ele sobre Luís Tinoco (p.107). Na versão do livro, as boas qualificações são suprimidas, e Tinoco só é contratado porque o advogado queria aumentar o número de militantes do partido (p.107).

Também a folha da qual Luís era o idealizador muda de nome. Deixa de ser Canapé literário e passa a ser chamada de Caramanchão Literário (p.108). Acreditamos que a troca do título acentue ainda mais a ironia instalada, já que "caramanchão" remete à ideia de algo próspero, verdejante, bemsucedido, bem diferente do fim que teve o periódico.

Na p.98 há uma substituição vocabular interessante. Em vez de peripatéticos, é usado o adjetivo vadios. Talvez Machado tenha achado essa troca necessária já que o primeiro termo tem um cunho histórico e cultural que o outro não reproduz. O primeiro termo também funcionava como um eufemismo que, ao ser substituído por vadios, perde toda a amenização da $1^{\mathrm{a}}$ versão.

Logo no início de "As bodas de Luís Duarte" / "As bodas do Dr. Duarte" (p.60), há algumas substituições interessantes. Na segunda versão, os títulos dos quadros são propriamente grafados em itálico com capitalizações e há a correção de uma inadequação que havia aparecido na primeira versão. Na versão do livro, ficamos sabendo que José Lemos tivera sido "membro" (em vez de "sócio") da sociedade literária quando fora "rapaz" (em vez de "criança").

Na p. 63 do conto, quando D. Beatriz pergunta à filha se ela realmente ama Luís Duarte, há a substituição do trecho "amava ao noivo sobre todas as coisas e ao próximo como a si mesma" por "amava o noivo tanto como a seus pais". O primeiro trecho dialogava com a passagem da BÍBLIA (1969) em Mateus 22:37-39 e gerava uma identificação dessa leitora de folhetim que provavelmente conhecia a passagem e acharia o trocadilho engraçado.

Quando descreve D. Margarida (p.64), esposa de Vilela, o escritor opta por "aumentar" o tempo de atenção que a senhora merecia (de dois para dez minutos). Desse modo, as descrições elogiosas feitas posteriormente fazem mais sentido do que antes, com o insuficiente tempo de dois minutos dispensados na primeira versão.

Na p.68, vemos Vilela "atacando" os salgadinhos da festa e nesse trecho há a troca de "o rebelde" por "aquela víscera" em referência ao estômago do personagem. Se analisarmos os elementos anteriores da frase, veremos que já havia sido usada a expressão "estômago rebelado". Talvez essa substituição possa indicar a preocupação do autor em evitar a repetição de termos tão próximos na frase.

Na hora do discurso de Porfírio, na p.72, há uma substituição que 
chama a atenção; o narrador, na primeira versão dizia que o tenente se achava o próprio S. João Crisóstomo. Na segunda versão, o sobrenome Crisóstomo é trocado pelo apelido mais conhecido do santo; Boca de Ouro. Isso pode ter acontecido com o intuito de gerar uma maior identificação, já que, provavelmente, S. João Boca de Ouro era um nome mais popular e mais conhecido pelos leitores. Além disso, Boca de Ouro relaciona-se melhor com o talento do santo (a qualidade retórica) e a aptidão tão almejada por Porfírio.

Outro fato curioso é a substituição do substantivo "romancista" por "narrador" (p.66). É possível que o escritor tenha dado conta, ao rever a primeira versão, que o que escrevia não era um romance e tenha preferido optar pelo termo mais genérico "narrador".

Na p.65, há a substituição de "acrescento eu" por "acrescentará o leitor". Esse parece ser um movimento buscado por Machado em apontar a distância que há entre o discurso do narrador, do leitor e do próprio escritor. Soares (1968) lembra de outros episódios do mesmo tipo em que vemos "a consciência linguística do escritor [que] repudia a linguagem de seu personagem e ao mesmo tempo teme (ou finge temer) que o leitor desavisado a tome por sua"(Soares, 1968:45).

Como podemos notar nas análises dos três processos mostrados anteriormente (omissão, adição e substituição), por meio do estudos dessas alterações conseguimos ter acesso a uma parte do trabalho de reescrita empreendido pelo autor e vemos também que Machado, enquanto ele próprio ia aprimorando e moldando seus textos, parece querer solicitar e esculpir também o tipo de leitor ideal de seus contos; "o leitor que souber ler", que ele já invocara em "A parasita azul". 


\section{Considerações Finais}

O objetivo do trabalho foi elaborar a edição crítico-genética virtual dos contos de Histórias da meia-noite e, a partir da análise das variantes, estabelecer hipóteses sobre os processos de criação relativos à reescrita dos textos.

Durante esse percurso, vimos algumas particularidades do Jornal das Famílias e do livro Histórias da meia-noite, onde foram publicadas, respectivamente, a primeira e a segunda versões dos contos. Foi possível compreender que muitos dos recursos estilísticos e muitas das soluções encontradas pelo escritor foram influenciados pelas exigências e normas de cada veículo.

Com o levantamento de informações sobre o contexto, vimos, também, que Machado esteve sempre muito atento aos leitores a quem se dirigia e conhecia as suas preferências e gostos muito bem, apesar de nem sempre ceder aos desejos deles.

Além disso, mostramos o caminho percorrido para o desenvolvimento da edição e do site, o que pode servir para a criação de outros projetos na área.

Disponibilizamos, em seguida, as edições critico-genéticas dos contos, que seguiram as normas descritas na Introdução crítico-filológica, e nas quais fica evidente o trabalho de reescrita e adequação empreendido pelo escritor.

A partir do levantamento das modificações, fizemos análises dos processos de omissão, adição e substituição. Levantamos várias hipóteses sobre essas alterações, mas que, obviamente, não são as únicas. Não foi nosso objetivo esgotar todas as possibilidades de interpretação para essas alterações, mas oferecer um ponto de vista sobre elas.

Não tratamos especificamente de todas as alterações nos contos, até porque, para muitas delas, não nos ocorre, agora, uma hipótese explicativa. Como explicar, por exemplo, algumas substituições vocabulares sinônimas, como "série de tolices" por "porção de tolices" (p.32), "imaginara" por "supusera" (p.40) em "A parasita azul". Ou então, outras alterações, como a substituição de pontos de exclamação por pontos de interrogação (e viceversa) que podem indicar alguma mudança de sentido ou correção autoral, 
mas também podem ser apenas alguma variação tipográfica (nas páginas 29 e 117, por exemplo).

Não podemos deixar de mencionar, ainda, as resistências e entraves que esse trabalho enfrenta ao tentar dialogar com áreas tradicionalmente pouco conectadas como o trabalho filológico, a critica literária e os meios eletrônicos. Apesar de parecer uma contradição, já que essas áreas têm muito a oferecer e complementar os estudos de um lado e de outro, o que vemos, às vezes, é uma falta de correspondência umas com as outras.

Em alguns casos, análises literárias são feitas baseando-se em edições, algumas até das mais respeitáveis, sobre um capítulo ou frase que, na realidade, quando confrontados pela filologia, mostram-se como erros de edição e até mesmo adições e exclusões não autorizadas pelo autor.

Da mesma forma, estudiosos de crítica textual focam-se apenas no estabelecimento do texto e, por vezes, deixam de dar o devido valor a descobertas de grande interesse para a interpretação de um texto literário.

Um bom exemplo da preocupação em unir as contribuições das áreas filológica e de crítica literária pode ser visto no texto de Santiago-Almeida (2010) onde há uma reflexão sobre a tarefa de preparar uma Edição Crítica de Dom Casmurro levando em conta traços e características próprios da escrita machadiana.

Quanto aos meios eletrônicos, talvez por sua própria natureza volátil, democrática e em constante alteração, o que percebemos é uma desvalorização do texto obtido pela Internet. Ele não é tão confiável, respeitável ou autorizado o suficiente quanto o texto em livro. Esse cenário já esta em transformação, parte pelos esforços dos editores que se preocupam cada vez mais com a qualidade dos textos publicados e com a adesão cada vez maior de revistas científicas que disponibilizam seus artigos em meio eletrônico. Os sites e projetos mencionados no início da dissertação também contribuem para isso.

O fato é que estamos em um momento de transição em que os papéis e regras ainda não foram totalmente definidos. Quanto a este trabalho, em particular, várias observações podem ser feitas se considerarmos a tradição do livro. Ele não se encaixaria exatamente na definição de Edição Crítica, já que esse tipo de edição, em sua maioria, procurar confrontar todos os testemunhos existentes, eliminar as cópias e estabelecer o textobase. Na introdução crítico-filológica devem constar todos os testemunhos consultados, mesmo os que não foram utilizados, justificando quais foram eliminados e por que razão. A Edição Crítica também só é possível se o texto for politestemunhal com variantes não-autorais, essas são as diferenças que valem para esse tipo de Edição. Já neste trabalho, estudamos as variantes de apenas dois testemunhos (a do Jornal das Famílias e a $1^{\text {a }}$ edição de Histórias 
da meia-noite) que o próprio autor tencionou realizar.

Ao mesmo tempo, o projeto não se encaixa somente no campo da Crítica Genética, que procura traçar o processo de criação do texto, porque pretende oferecer um texto também mais próximo da última intenção do autor. No caso dos contos que são objetos de estudo nesse trabalho, não há manuscritos autógrafos nem notas, esboços etc. No entanto, sabemos que a Crítica Genética ainda é possível com os originais idiógrafos (textos impressos supervisionados pelo autor).

Nosso objetivo é oferecer também, além de um texto confiável e fidedigno, ampla visualização e acessibilidade desses textos por meio do uso da internet e utilizar as ferramentas eletrônicas disponíveis para facilitar a edição, leitura e interpretação das variantes do texto.

Aí esbarramos em outra dificuldade; a de disponibilizar a leitura de um autor canônico, como é o caso de Machado de Assis, em um suporte contemporâneo, como a internet. A tradição prevê um modelo de edição (crítica ou genética) que siga as regras e normas de publicação em livro. Assim, as variantes em uma edição crítica, por exemplo, geralmente listadas no aparato, aparecem no rodapé da página acompanhadas da sigla do manuscrito e numeradas por período (de 5 em 5 linhas, por exemplo). No entanto, em uma edição virtual, como já salientamos, podemos utilizar recursos variados e mais apropriados que permitem uma melhor visualização das variantes do texto.

Sendo assim, percebemos que, ao propor novas bases para a edição desses textos, cria-se um conflito bastante interessante entre o antigo e o novo, entre a tradição e a modernidade que não pode passar despercebido e deve ser também objeto de reflexão.

Retomando os questionamentos apresentados na Introdução, acreditamos que esse trabalho contribui para o estudo das obras machadianas por mostrar um perspectiva nova e tratar de contos ainda pouco estudados.

No campo da Edição ainda há muito o que se fazer com os textos de Machado de Assis. O nosso maior escritor não possui ainda uma Obra Completa definitiva, apesar de as grandes editoras frequentemente lançarem coleções desse tipo.

Pouco conhecemos sobre o processo de criação de Machado de Assis. O escritor deixou poucos rastros, quase nenhum manuscrito e os documentos sobre a gênese dos textos são quase inexistentes. Uma edição genética de idiógrafos impressos oferece, de certa forma, uma solução para esse problema.

Por meio do uso das ferramentas informáticas, vimos que é possível visualizar facilmente o trabalho de reescrita que Machado empreendeu. Esse tipo de edição pode também servir a outros pesquisadores que queiram se 
debruçar sobre esse trabalho.

Por meio da análise das modificações foi possível mostrar como Machado trabalhou no sentido de se afastar dos padrões da época, privilegiando, na reescrita dos textos, o distanciamento crítico, a reflexão e a análise.

Podemos perceber, assim, um escritor crítico da própria obra, que se faz ao mesmo tempo leitor de si mesmo, atento ao seu entorno e às questões de seu tempo.

Desse modo, podemos concluir que, ao reescrever os contos, verificamos também um movimento do escritor em convocar o leitor a participar da narrativa, exigindo uma postura mais ativa na construção do sentido do texto.

Machado de Assis parece querer moldar e solicitar, desde aquela época, o leitor "ruminante", reflexivo, que estará efetivamente configurado em seus textos posteriores. 


\section{Referências Bibliográficas}

AssIs, Machado de. Histórias da meia-noite, vol. 4. Rio de Janeiro: Civilização Brasileira, 1975. Texto estabelecido pela Comissão Machado de Assis.

Azevedo, Silvia Maria. A trajetória de Machado de Assis; do Jornal das Famílias aos contos e histórias em livros. Tese de Doutoramento, USP, São Paulo, 1990.

Azevedo, Sílvia Maria. "Machado de assis entre o jornal e o livro". O Eixo e a Roda: Revista de Literatura Brasileira, vol. 16, 167-177, 2012. Disponível em: <http://www. letras.ufmg.br/poslit/08_publicacoes_pgs/ Eixo $\% 20$ e\%20a\%20Roda\%2016/12-Silvia\%20Azevedo.pdf $>$. Última consulta: 02 jan. 2013.

Blecua Perdices, Alberto. Manual de crítica textual. Editorial Castalia, 1983.

Bosi, Alfredo. A máscara e a fenda, pp. 437-457. São Paulo: Ática, 1982.

BÍBLIA. Edição revista e corrigida. Traduzido em português por João Ferreira de Almeida. Sociedade Bíblica do Brasil, 1969.

CAmbraiA, César Nardelli. Introdução à crítica textual. São Paulo: Martins Fontes, 2005.

CAstro, Ivo. Editar Pessoa, vol. 1. Impr. Nacional-Casa da Moeda, 1990a.

CASTRO, Ivo. "Enquanto os escritores escreverem". In: IX Congresso Internacional da Associação de Linguística e Filologia da América Latina. Campinas, 1990b. [As citações foram retiradas de um texto que o próprio autor gentilmente me enviou].

CASTRO, Ivo. "O retorno à filologia”. In: Miscelânea de Estudos Linguísticos, Filológicos e Literários in Memoriam Celso Cunha, pp. 511-520. Rio de Janeiro: Nova Fronteira, 1995. 
CAstro, Ivo. "Metodologia do aparato genético". In: Memória dos Afectos (Homenagem a Giuseppe Tavani), pp. 69-81. Lisboa: Colibri Edições, 2001. Disponível em: <http://www.clul.ul.pt/files/ivo_castro/ 2001_aparato_gentico.pdf> Última consulta: 13/05/13.

Chartier, Roger. Os desafios da escrita. São Paulo: Unesp, 2002.

CHARTIER, Roger. Inscrever e apagar: cultura escrita e literatura (séculos XI-XVIII). Unesp, 2007.

Crestani, Jaison Luís. Machado de Assis no Jornal das Famílias. São Paulo: Nankin, EDUSP, 2009.

FRANÇA, Eduardo Melo. Ruptura ou amadurecimento? Uma análise dos primeiros contos de Machado de Assis. Recife: Editora Universitária UFPE, 2008.

FURUTA, Richard, KALASAPUR, Siddarth. S., KOCHUMMAN, Rajiv, URBINA, Eduardo \& VIVANCOS-PÉREZ, Ricardo. “The cervantes project: Steps to a customizable and interlinked on-line electronic variorum edition supporting scholarship". In: Research and Advanced Technology for Digital Libraries, pp. 71-82. Springer, 2001. Disponível em: <http: //cervantes . tamu . edu/pubs/ecdl2001cp.pdf>. Última consulta: 05 jul. 2013.

Guimarães, Hélio de Seixas. Os leitores de Machado de Assis: o romance machadiano e o público de literatura no século 19. São Paulo: Nankin, EDUSP, 2004.

GuimarÃes, Júlio Castañon. Sobre um projeto de Edição Crítico-genética da Poesia de Carlos Drummond de Andrade, vol. 31. Fundação Casa de Rui Barbosa, Ministério da Cultura, 1997.

Hallewell, Laurence. O livro no Brasil: sua história. São Paulo: Edusp, 2005.

LOPES, Célia Regina dos Santos. "Retratos da mudança no sistema pronominal: o tratamento carioca nas primeiras décadas do século $\mathrm{xx}^{\prime \prime}$. In: CORTINA, Arnaldo \& NASSER, Silvia Maria Gomes da Conceição (Orgs.), Sujeito e linguagem: Séries Trilhas Linguísticas, vol. 17, pp. 47-74. Araraquara: Cultura Acadêmica, 2009. Disponível em: <http://www . letras.ufrj.br/laborhistorico/producao/araraquara.pdf $>$. Última consulta: 02 jan. 2014. 
Lopes, Célia Regina dos Santos \& MACHAdo, Ana Carolina Morito. “Tradição e inovação: indícios do sincretismo entre a segunda e a terceira pessoas nas cartas dos avós". In: LOPES, Célia Regina dos Santos (Org.), Norma brasileira em construção: fatos linguísitcos em cartas pessoais do século XIX, pp. 45-66. Pós-Graduação em Letras Vernáculas da UFRJ, FAPERJ, 2005. Disponível em: <http://www. letras.ufrj.br/posverna/ docentes/70994-1.pdf>. Última consulta: 02 jan. 2014.

MASSA, Jean-Michel. A juventude de Machado de Assis (1839-1870): Ensaio de Biografia Intelectual. Rio de Janeiro: Civilização Brasileira, 1971.

MEGÍAS, José Manuel Lucía. "La edición crítica hipertextual: hacia la superación del incunable del hipertexto". In: Lecturas y textos en el siglo XXI, pp. 11-74. Axac, 2009. Disponível em: <http://eprints.ucm.es/8687/1/ La_edici $\%$ C3\%B3n_cr $\%$ C3\%ADtica_hipertextual.pdf $>$. Última consulta: 24 maio 2013.

Minchillo, Carlos. "Salto triplo para queda em falso: uma leitura de "Aurora sem dia", de Machado de Assis". Machado de Assis em Linha, vol. 1, no. 5, 16, 2010. Disponível em: <http://machadodeassis . net/download/numero05/num05artigo08 .pdf> Última consulta: $11 \mathrm{dez}$. 2013.

PINHeiro, Alexandra Santos. Para além da amenidade-O Jornal das Famílias (1863-1878) e sua rede de produção. Tese de Doutoramento, Campinas: Unicamp, 2007.

PINO, Claudia Amigo \& ZULAR, Roberto. Escrever sobre escrever: uma introdução crítica à crítica genética. São Paulo: Martins Fontes, 2007.

Ribeiro, José Alcides. Imprensa e ficção no século XIX. São Paulo: Unesp, 1996.

RiBEIRO, José Alcides. "Ficção e imprensa no brasil: os processos de criação de Machado de Assis, Joaquim Manuel de Macedo e José de Alencar". Manuscrítica Revista de Crítica Genética, vol. 1, no. 14, 101-115, 2006.

SAntiago-Almeida, Manoel Mourivaldo. "Para uma nova edição crítica de Dom Casmurro". Caligrama: Revista de Estudos Românicos, vol. 15, no. 2, 189-202, 2010.

SARAIVA, Juracy Assmann. "Entre o folhetim e o livro: a exposição da prática artesanal da escrita". In: GUIDIN, Márcia Lígia, GRANJA, Lúcia 
\& RICIERI, Francine Weiss (Orgs.), Machado de Assis ensaios da crítica contemporânea. São Paulo: UNESP, 2008.

SILVA, Ana Cláudia Suriani da. Linha reta e linha curva: edição crítica e genética de um conto de Machado de Assis. Campinas: Editora da Unicamp, 2003.

Silva, Ana Cláudia Suriani da. Machado de Assis's Philosopher or Dog? From serial to book form. Londres: Legenda; Modern Humanities Research Association, 2010.

SILVA, Andreza da \& BARCiA, Lucia Rosado. "Vossa mercê, você, vós ou tu? a flutuação de formas em cartas cariocas dos séculos xviii e xix". Ao Pé da Letra, vol. 4.1, 21-30, 2002. Disponível em: <http:// www.revistaaopedaletra.net/volumes/vol\%204.1>. Última consulta: 10 dez. 2013.

SOARES, Maria Nazaré Lins. Machado de Assis e a análise da expressão. Instituto Nacional do Livro, 1968.

URbINA, Eduardo, FURUTA, Richard \& HU, Shueh-Cheng. "El arte nuevo de editar textos en este tiempo". Espéculo, vol. 1, no. 12, 1999. Disponível em: <http://www.ucm.es/info/especulo/numero12/artenuev.html>. Última consulta: 21 maio 2013.

Willemart, Philippe. Bastidores da criação literária. São Paulo: Iluminuras, 1999. 